UNIVERSIDADE DE SÃO PAULO

FACULDADE DE EDUCAÇÃO

ANA CAROLINA CORRÊA SOARES DE CAMARGO

\title{
A função pendular do educador
}




\section{A função pendular do educador}

Versão corrigida da dissertação apresentada à FEUSP como parte dos requisitos para a obtenção de título de Mestre em Educação. A versão original encontra-se disponível na biblioteca da FEUSP

Linha de pesquisa: Psicologia e Educação.

Orientador: Prof. Dr. Leandro de Lajonquière 
AUTORIZO A REPRODUÇÃO E DIVULGAÇÃO TOTAL OU PARCIAL DESTE TRABALHO, POR QUALQUER MEIO CONVENCIONAL OU ELETRÔNICO, PARA FINS DE ESTUDO E PESQUISA, DESDE QUE CITADA A FONTE.

Catalogação na Publicação

Serviço de Biblioteca e Documentação

Faculdade de Educação da Universidade de São Paulo

37.046 Camargo, Ana Carolina Corrêa Soares de

C172f A função pendular do educador / Ana Carolina Corrêa Soares de Camargo; orientação Leandro de Lajonquière. São Paulo: s.n., 2011.

268 p. ils.; grafs.; anexos

Dissertação (Mestrado - Programa de Pós-Graduação em Educação. Área de Concentração: Psicologia e Educação) - - Faculdade de Educação

1. Educação 2. Psicanálise 3. Psicopedagogia 4. Métodos de ensino 5. Discurso I. Lajonquière, Leandro de, orient. 


\section{Ana Carolina Corrêa Soares de Camargo}

\section{A função pendular do educador}

Dissertação apresentada à Faculdade de Educação da Universidade de São Paulo como parte dos requisitos para a obtenção de título de Mestre em Educação.

Linha de pesquisa: Psicologia e Educação.

Orientador: Prof. Dr. Leandro de Lajonquière

Banca examinadora:

Profa. Dra. Maria Cristina Kupfer

Prof. Dr. Rinaldo Voltolini

Prof. Dr. Leandro de Lajonquière (FEUSP)

Data de aprovação: 



\section{DEDICATÓRIA}

Não escrevo a diplomas, bibliotecas

Reiterando autores, teorias

Escrevo a colegas e a mim

Educadores.

Parto de reminiscências, cavoucos

Dia a dia professora estudante

Experiência vivida, em anos,

Com alunos postados nas encruzilhadas

Da tortura e do prazer

No giro automotor,

Anorexia escolar.

Para isso que aparece e não se compreende

Causas são aventadas:

Família desestruturada, pais ausentes,

Baixo quociente de inteligência, formação precária do professor

Deficiências múltiplas da escola, do aluno, do currículo escolar

Acenos de fracasso - quando não o engodo da aprovação automática Apelam a recursos paraeducativos-pedagógicos.

Eu, mais um.

Déficit de atenção, hiperatividade, fobia escolar, síndrome do pânico

Depressão, dislexia, disgrafia, disortografia

Dislalia, discalculia, inibição intelectual

Debilidade mental, Síndrome de Asperger

Dificuldades, transtornos da aprendizagem

DSM-IV ${ }^{1}$, CID- $10^{2}$

Discurso pedagógico amalgamado ao discurso psi

Demanda a escolaridade ideal

Discurso médico acoplado ao Discurso Universitário, em nome da Ciência,

Fomento do Discurso do Capitalista

Consumo crescente, ilícito ou não

\footnotetext{
${ }^{1}$ Manual de Diagnóstico e Estatística das Perturbações Mentais.

${ }^{2}$ Classificação Estatística Internacional de Doenças e Problemas Relacionados com a Saúde, classificação estatística internacional das doenças, ferimentos e causas da morte publicado pela Organização Mundial de Saúde (OMS).
} 
Psicotrópicos "escolares" de última geração

Em sites de relacionamento,

Jovens internautas divertem-se

$\mathrm{Na}$ apologia do uso recreativo da "Rita":

Metilfenidato, similar à anfetamina.

Comércio ilegal em baladas a bebidas

Produtos farmacêuticos para os quais faltam

Pesquisas longitudinais.

Na tentativa de confundir certezas e abrir espaços para outras implicações,

Cerzir tecidos da educação com retalhos da literatura

Me interessa

Do cinema, da MPB, do Tai Chi Chuan, da Homeopatia Hahnemanneana

Do clown, da pedagogia e da psicanálise, quando possível, também.

Na confluência de leituras,

No prazer e no esforço de procurar e escavar autores,

Trago ao exercício, quiçá acadêmico

Um pouco daquilo que intuo ter me feito herdeira

É o que posso oferecer

Àqueles que, como eu, meio sem-querer-querendo,

Atiram-se e permanecem se debatendo

No rego da Educação. 


\section{AGRADECIMENTOS}

Ao Nelson, pela amizade, paciência e amor

Aos meus filhos, Gabriel e Rebeca, pela oportunidade de inventar-me como mãe

A Alice e Alda, pela companheirismo feminino, não muito comum

A Lígia Mori, Nausica Riatto e Paula Maria Leopoldina, da ENSG, pela parceria e confiança

Aos "meus" alunos e alunas, pela inspiração

Aos pais deles, pela oportunidade de inventar-me como educadora

Ao Rodolpho Ruffino, pelo desejo do analista - imprescindível

Ao Vagner Barnabé, pela sensível, assertiva e (mal)humorada clínica homeopática

Ao Christian Dunker, pela elegância do pendular na qualificação

A Maria Cecília Cortez, pelas difíceis verdades

Ao João Ribeiro, pela revisão, e por ter sido, um dia, meu professor de português

À FEUSP, por me receber, por transferência

Ao meu pai, pelo ensi(g)no do gostar de livros

A minha mãe, pelo ensi(g)no sobre a pulsão de morte

Ao Leandro, pelo agalma que leva por dentro

A eujemoi, por inscrever outro significante para "anãzinha retardada", sua implicação. 

Afirmar que todos os conceitos e noções da psicanálise só fazem sentido na clínica e que esta é soberano privilégio dos psicanalistas é testemunho patente da rigidez ideológica e fixação de fronteiras impermeáveis. (...) estamos falando (...) da inscrição da psicanálise nas práticas de subjetivação da modernidade. Ou seja, ela participa como dispositivo de saber e tratamento, do modo como pensamos a nós mesmos, dos instrumentos de uma tecnologia de si e de suas formas coextensivas de poder. (...) É como uma espécie de complemento invertido para a retórica que encontramos no período helenístico as práticas do cuidado de si (...) pela primeira vez se examinam as condições e se realiza uma prática orientada para a enunciação de uma verdade própria do sujeito. Não é uma verdade interior, muito menos uma verdade individual, ela ocorre em um espaço limítrofe entre a educação e a ação política. Encontramos assim a idéia de que não há outro ponto, primeiro e último, de resistência ao poder político senão na relação de si para consigo. Combinação entre arte e medicina da alma, de filosofia e ciência da vida cotidiana, o cuidado de si nos oferece um novo repertório de temas e táticas que a psicanálise virá retomar: a interpretação dos sonhos, o método de cura, a meditação, a importância da relação de fala, da rememoração e a implicação do sujeito em seu próprio destino, são exemplos de táticas e estratégias para realização desse giro para si e retorno ao outro. (...) aqui se verifica um tipo especial de política, uma política de recusa às políticas se assim for possível dizer. É compreensível que o cuidado de si tenha sido a matriz sobre a qual se erigem os dispositivos da confissão, da sexualidade e da conversão. Mas o próprio percurso mostra que esta assimilação não é necessária, mas contingência da instalação de uma nova forma de micropoder (DUNKER, 2007).

Christian Ingo Lenz Dunker

Na sua essência, a transferência eficaz de que se trata é simplesmente o ato da palavra. Cada vez que um homem fala a outro de maneira autêntica e plena, há, no sentido próprio, transferência, transferência simbólica - alguma coisa se passa que muda a natureza dos dois seres em presença (LACAN, 1953, p. 54).

Jacques Lacan

Se vocês se referirem à teoria analítica como um dogmatismo, quer dizer, se a tratarem como uma religião, vocês matarão seu fundador. É o que fizeram os alunos de Freud. Eles trataram seu ensino como dogmático, em que nada podia ser tocado ou mudado, como nas preces, eles o mataram (...) Eles trataram Freud como se trata um pai morto. Para Lacan, é bem evidente que pode ser igual. Se Lacan for tratado de um modo dogmático, ele irá desaparecer. O que torna difícil o estudo de Lacan é que não se chega jamais a capturar nada, nunca. Vocês tentam definir um conceito lacaniano; sua utilização muda o tempo todo. Vocês tentam apreender o que constituiria o essencial de Lacan, mas não alcançarão nunca. Quando os filósofos leem Lacan ficam horrorizados porque o ensino de Lacan é sempre organizado em torno de um furo. Quer dizer que os significantes apenas circulam em torno deste furo e isso é que ele quer ensinar a seus alunos. Pois essa é a lição que aprendemos com a prática psicanalítica: somos dependentes de um sistema, que é simbólico, que só permite alcançar, pegar nada mais que um furo. E como é nesse furo que nossa existência toma lugar, somos amedrontados porque não há nada que a sustente (MELMAN, 2004).

Charles Melman 
CAMARGO, Ana Carolina Corrêa Soares de. A função pendular do educador. São Paulo, 2011. Dissertação (Mestrado). Faculdade de Educação da Universidade de São Paulo.

\section{RESUMO}

Qual a função do educador? Esse foi o mote desta pesquisa, na tentativa de aprofundar os questionamentos a respeito da prescindibilidade psicometodológica tanto para a ação pedagógica, quanto para a formação do educador, utilizando o escopo da psicanálise freudolacaniana para as inflexões que se seguem. Por entender que o campo da palavra e da linguagem, inexoravelmente, está implicado na constituição do sujeito e, devido a isso, não há um tempo para que a mesma seja concluída, voltamo-nos ao entendimento da teoria dos discursos de Lacan para focalizar o discurso pedagógico ortodoxo, antepondo às figuras do ortodoxo e do obsessivo uma educadora sui generis do final do século XIX, que pouco sabia das pedagogias tecnocientíficas da época e, mesmo assim, encontrou meios de levar a cabo a educação de uma menina de 7 anos, cega, surda, muda e que não havia aprendido ainda a falar, nem a utilizar a linguagem dos sinais: Helen Keller. Na tentativa de desdobrar os fatores que teriam funcionado tão bem nessa experiência desafiadora, direcionamos nossas indagações a respeito do estilo de endereçamento do educador, desembocando num protomodelo pendular, inspirado num dos mais belos experimentos da Física, o pêndulo de Foucault, em cujo ponto de sustentação para a palavra educ(a)tiva alocamos - em liberdade relativa de giro - o estilo , assentado não nos conhecimentos psicotecnocientíficos da pedagogia ortodoxa, mas no objeto $a$, objeto causa de desejo, conceito lacaniano fundamental dentro da teoria psicanalítica. Finalizamos nosso percurso de pesquisa, enfim, descrevendo o funcionamento desse hipotético pendular, cujas extremidades nomeamos como desejo-dopedagogo e Nome-(im)próprio - espécies de reedições daquilo que, um dia, na vida do sujeito, cumpriu a função simbólica de mãe e pai.

PALAVRAS-CHAVE: educação, psicanálise, psicopedagogia, métodos de ensino, discurso. 


\section{ABSTRACT}

What's the educator function? That's the objective of this research, in the attempt of going deeper in the questions about the unnecessary psychological methodology of the pedagogic action but the educator formation as well, using the target of Freud and Lacan theories for the inflexion that follow. For understanding the field of word and language, inexorably, it's implied in the constitution of subjects and, because of it, there's no time for it to be concluded, so we get back to the theory of speeches, in Lacan, to focus in the orthodox learning method, opposing between the figures of the orthodox and the obsessive an educator sui generis, of the end of the XIX century that knew only a few of the scientific pedagogic methods of that time and, even then, has found ways to connect the education of a seven years old girl who was blind, mute, deaf and still had never learned to talk or to use language of signs. Helen Keller. In the attempt to unroll the factors that have functioned in this defying experience, we direct our doubts to the style of the mode of adress of each educator suggesting a pendulum model, inspired in one of the most beautiful experiments of physics, the pendulum of Foucault, witch point of sustentation for the educative word we locate - in freedom relative of spin - the style, putted not in the scientific and psychological knowledge of orthodox pedagogical methods, but in the object $a$, object of desire, one of the main concepts insides of Lacanian theory. So we end our psychological research, just with the description of this hypothetic pendulum witch extremes are named as "desire-ofthe-pedagogue" and "proper-name" - a kind of reprint of what someday in the life of the subject, may fulfill the parental function .

Key-words:

Education - psychoanalysis - pedagogy - methodology of teaching - speech 
Introdução.

1 Educ(a)tio

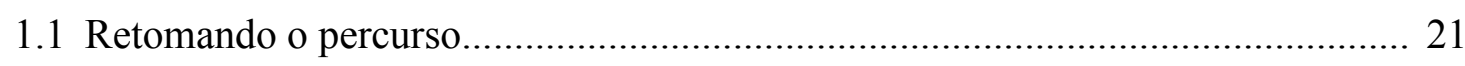

1.2 Educar-enodar-enlaçar: reedição do trígono edipiano........................................ 27

1.3 Qual o tempo para um sujeito advir, formar-se, vir-ar-ser?............................ 32

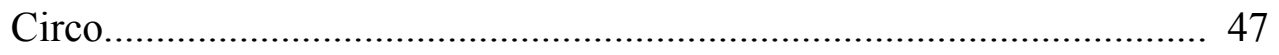

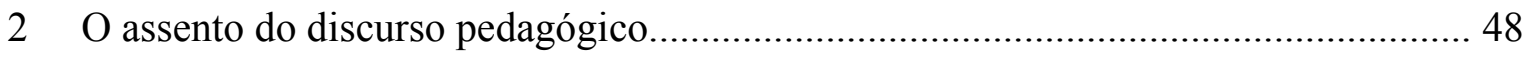

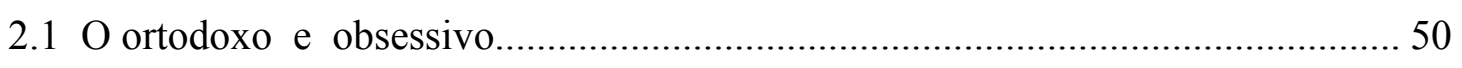

2.2 Anne Sullivan e o assento construtivista-sócio-interacionista...........................56

2.3 Os discursos em Lacan e em Anne Sullivan

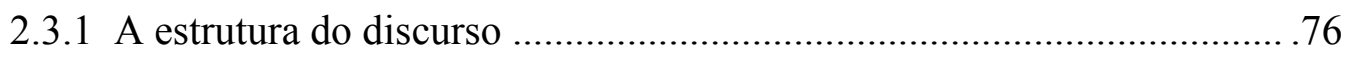

2.3.2 O discurso do mestre, discurso inconsciente........................................ 86

2.3.3 Discursos universitário, da ciência, da educação...................................89

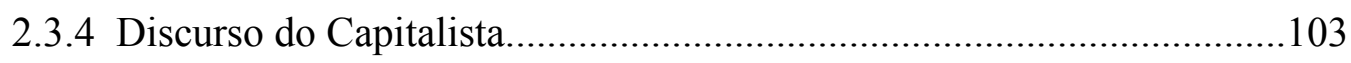

2.3.5 Discurso da Histeria e do Analista.......................................................106

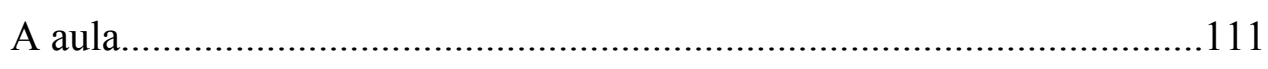

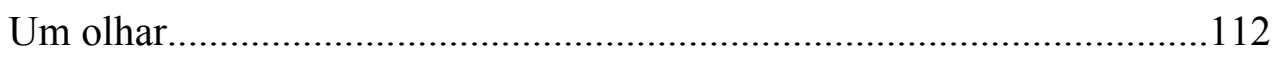

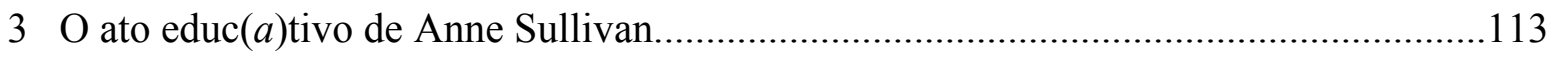

3.1 Sullivan mancava, ou da ferida narcísica do pedagogo ortodoxo.........................120

3.2 Em nome da ciência, o esvaziamento do estofo educ $(a)$ tivo................................140

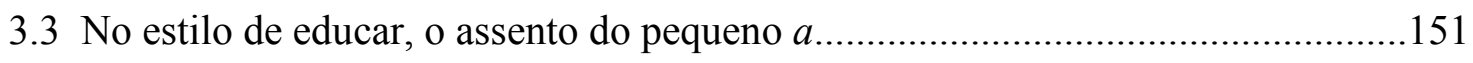

3.3.1 No estofo do estilo, a dialética do reconhecimento....................154

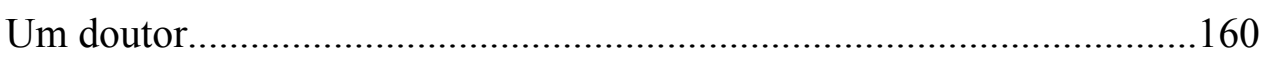

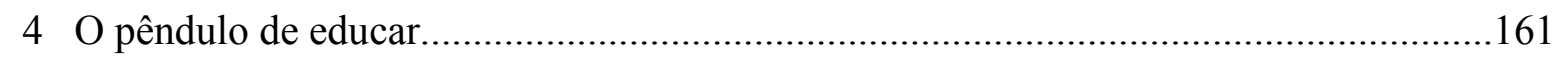

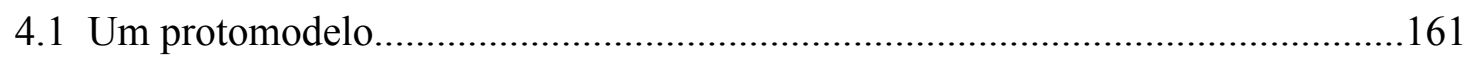

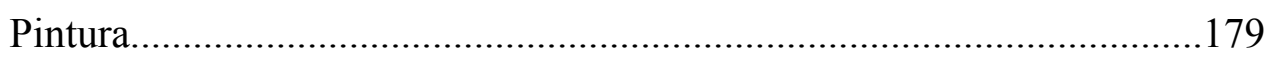

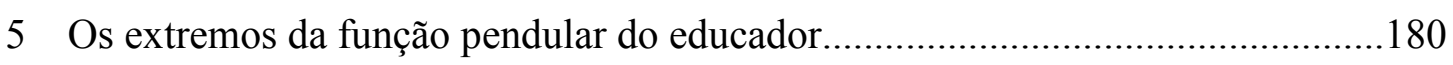

5.1 Da função materna ao desejo-de-pedagogo................................................183

5.2 Da função paterna ao Nome-(im) próprio...................................................209

5.2.1 Do fazer-se herdeiro de um dever de ser ao extremo do Nome-(im)próprio 


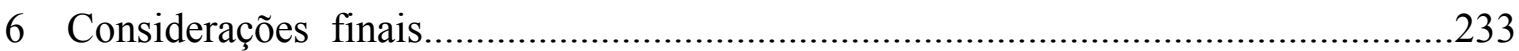

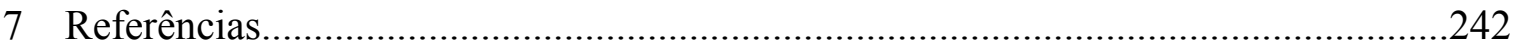

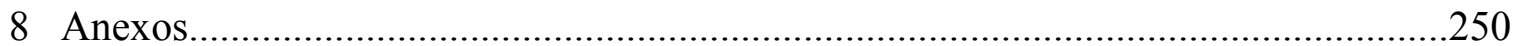




\section{INTRODUÇÃO}

O estudo presente tem o intuito de aprofundar certas discussões e questionamentos levantados em Educar: uma questão metodológica? Proposições psicanalíticas sobre o ensinar e o aprender, de minha autoria, sob a orientação de Leandro de Lajonquière. Passados cinco anos, no momento de organizar a pesquisa de mestrado para outro escrito, verifico com alguma surpresa que nesta etapa acadêmica não fiz outra coisa que retomar as ideias do capítulo inicial do trabalho anterior, a saber, os "Sentidos de Educar", incrementando a argumentação para o embate com aquilo que não pude deixar de nomear Pedagogia Ortodoxa.

Valendo-me das origens etimológicas do termo (educatio/eductio), tinha em mente, na época, trabalhar a hipótese de que o educar estaria intimamente ligado a uma espécie de movimento pendular que, por parte do educador, oscilaria entre deixar fazer e proibir, incentivar e reprimir, oferecer e exigir, tal como indicara Freud na citação de Cila e Caribde ${ }^{1}$, dois monstros devastadores pelos quais Ulysses e os argonautas teriam que passar e sobreviver por mais de uma vez ${ }^{2}$. Durante o processo de pesquisa para o trabalho presente, pudemos constatar que a articulação entre educatio e eductio feita no trabalho anterior não somente era procedente, como podia ser revisitada e a discussão ampliada. Tencionava relacionar o educar àquilo que a Psicanálise conceitua como funções materna e paterna, numa dinâmica pendular mais ligada à arte da escuta, do improviso, da lida com a Transferência/Contratransferência e da ligação autêntica com o Conhecimento, do que à presteza na aplicação de técnicas metodológicas derivadas de teorias psicogenéticas que desembocam, não raramente, em práticas pedagógico-educativas muitas vezes

\footnotetext{
${ }^{1} \mathrm{Na}$ tradução da Imago, Cila está escrito com S. Entretanto, optamos pela grafia que Donaldo Schüler usou na edição bilíngue da Odisseia, traduzida diretamente do grego para o português, publicada pela L\&PM em 2007. Quanto à citação de Freud sobre Cila e Caribde, disponibilizamos o seguinte trecho: "Vamos tornar clara para nós mesmos qual a tarefa primeira da educação. A criança deve aprender a controlar seus instintos. É impossível conceder-lhe liberdade de pôr em prática todos os seus impulsos sem restrição. (...) Por conseguinte, a educação deve inibir, proibir e suprimir, e isto ela procurou fazer em todos os períodos da história. Na análise, porém, temos verificado que precisamente essa supressão dos instintos envolve o risco de doença neurótica. (...) Assim, a educação tem de escolher seu caminho entre o Sila da não interferência e o Caríbdis da frustração. A menos que o problema seja inteiramente insolúvel, deve-se descobrir um ponto ótimo que possibilite à educação atingir o máximo com o mínimo de dano. Será, portanto, uma questão de decidir quanto proibir, em que hora e por que meios.", in FREUD, S. "Novas Conferências Introdutórias sobre Psicanálise - Conferência XXXIV: Explicações e Orientações" (1933). Edição Standard brasileira das Obras Psicológicas completas de Sigmund Freud. Rio de Janeiro: Imago, 1996, p.147.
}

${ }^{2}$ No ANEXO A, o leitor poderá encontrar as duas passagens em que aparecem as descrições de Cila e Caribde na Odisseia de Homero, pela tradução de Schüler. 
enclausuradoras, quando não inférteis, embora legitimadas pelo discurso da ciência multi e interdisciplinar no campo das Ciências da Educação. Poderia ter levado a cabo tal investigação, porém acabei enveredando pelo que imaginava ser certas "proposições psicanalíticas", em especial aquelas relacionadas a curiosidades prementes que permitiam jogar em discussão um pouco do que a experiência como educadora não cessava de retornar $^{3}$, questionando de forma contundente o paradigma pedagógico da imprescindibilidade dos métodos de ensino.

$\mathrm{Na}$ retomada da pesquisa, exigindo ladrilhagem para outros caminhos, reminiscências embaladas em mais de duas décadas de prática educativa sussurravam outras máximas na base de nossos questionamentos. E então, voltamos a partir. De onde?

Partimos-partindo de alguns princípios que a nosso ver deveriam estar na base do saber-fazer pedagógico-educativo: (1) Dar-se conta da presença constante do inconsciente no campo educativo compõe uma das dimensões que a Psicanálise acentua como engajamento ético do educador ${ }^{4}$ no reconhecimento da ex-istência ${ }^{5}$ de uma fala e do desejo, seja do aluno, seja do professor; (2) O laço autêntico do educador com a Cultura, em particular com o objeto de conhecimento que tem por intuito ensinar, fala mais alto e melhor aos educandos que qualquer prática docente alicerçada em prescrições metodológicas condizentes com hipotéticos níveis do desenvolvimento cognitivo ou zonas proximais, em sintonia ou não com a pretensa adequação dos meios pedagógicos aos fins educativos pré-estabelecidos; (3) que questões sobre estilo, modos de endereçamento e do encarne à função de educador são

\footnotetext{
3 "O retorno do recalcado, terceiro tempo do recalque, manifesta-se sob a forma de sintomas - sonhos, esquecimentos e outros atos falhos - considerados por Freud com formações de compromisso. (...) O recalque não lida apenas com as pulsões em si, mas com seus representantes, imagens ou ideias, os quais, apesar de recalcados, continuam ativos no inconsciente, sob a forma de derivados ainda mais prontos a retornar para o consciente, na medida em que se localizam na periferia do inconsciente. O recalque de um representante da pulsão nunca é definitivo, portanto. Continua sempre ativo, daí um grande dispêndio energético" (ROUDINESCO; PLON, 1944, p. 648-649, grifo nosso).

${ }^{4}$ Ver, de Francis Imbert, A questão ética no campo educativo, publicado pela Editora Vozes, Coleção Psicanálise e Educação, 2001.

${ }^{5}$ Ex-sistência: Termo cunhado por Lacan para designar um existir que transcende o lugar predeterminado ao sujeito pelo discurso do Outro - sobre Outro. "No Seminário Mais, Ainda (1982), Lacan propõe o Outro gozo, ex-sistente, suplementar, próprio da posição feminina da sexuação e testemunhado pela experiência do êxtase místico (1982, p. 103). A raiz das duas palavras - êxtase e existência - é a mesma e significa, em grego, ficar do lado de fora, ficar a parte de alguma coisa. (...) Nas traduções de Heidegger para o francês, apareceu pela primeira vez a palavra ex-sistência para a palavra grega ekstasis e a alemã ekstase, segundo Bruce Fink, em $O$ sujeito lacaniano: entre a linguagem e o gozo, Rio de Janeiro, Jorge Zahar, 1998, p.151. Se naquela língua esse termo era utilizado para dizer o estado de "extático", Lacan utiliza a palavra ex-sistência para dizer "uma existência separada de", do lado de fora, fora da estrutura.", in Desafios clínicos da histeria: desejo, gozo e melancolia, de Miriam Nogueira Lima, apresentado na Reunião Lacanoamericana de Rosário, 1999. Disponível em: http://www.herreros.com.ar/melanco/lima.htm. Acesso em 30/09/2010.
} 
facetas da atividade educativa merecedoras de atenção; e (4) que a sutileza de uma escuta flutuante - mantida à distância da selvageria analítica, é posto - pode servir, sim, de instrumento, tanto na lida com o alunado, quanto, e principalmente, na lida para consigo mesmo, para com o grupo de colegas de trabalho e para com os pais dos alunos quando se faz necessário conversar sobre a vida escolar. Mesmo fora do set analítico e sem objetivo de cura, a escuta para o educador - seja este professor ou não - mostra-se útil nos desaprumos transferenciais e contratransferenciais, podendo ajudar a decidir, em nome próprio, em que hora e por quais meios dar voz e corpo à contenção de um "não", mas também ao acolhimento, ao azeitar convidativo de um "sim", na convocação ao educando para que opere, suporte e canalize os restos da renúncia de seus "instintos mais primitivos, egoísticos e cruéis" - como dizia Freud - exigidos pelo laço social.

Firmamos, porém mais uma e uma vez, que o esforço em casar e conectar conhecimentos e saberes da Psicanálise ao campo pedagógico/educativo não serve, jeito maneira, para garantir o sucesso da empreitada educativa, nem tem por objetivo fazê-lo. Lembremos a máxima freudiana sobre educar, governar e analisar como profissões impossíveis, uma vez que lidam com sujeitos determinados psiquicamente pelo inconsciente, contanto que "impossível” seja tomado como “(...) modo de experiência subjetiva que parece sempre exceder nossa capacidade de simbolização e de transposição em imagens. Ponto de excesso a respeito do qual cada sujeito só poderá lidar através de um arranjo singular" (SAFLATE, 2007, p. 76); uma vez que “Impossivel não é sinônimo de irrealizável, mas indica apenas a ideia de algo que não pode jamais ser integralmente alcançado: o domínio, a direção e o controle que estão na base de qualquer sistema pedagógico” (KUPFER, 2000, p. 59).

É compreensível que, para Freud, educar fosse uma profissão impossível, ao lado das tarefas de psicanalisar e governar (Análise terminável e interminável). Certamente impossível, como indicou ele, em razão do "sucesso insuficiente" que podemos esperar dela, mas principalmente impossível, segundo cremos, pelo fato de nenhuma formação ser suficiente para que ela seja corretamente exercida. Educar - assim como psicanalisar faz parte dessas profissões que exigem um "algo a mais" que nenhuma instrução e nenhum entendimento é capaz de trazer" (CHÈMOUNI, 1996, p. 630).

Justamente por conta disso ${ }^{6}$ enquanto premissa, "a Psicanálise não serve como fundamento para uma pedagogia; nem pode servir como princípio organizador de um sistema

\footnotetext{
${ }^{6} \mathrm{O}$ conjunto de livros $O$ Seminário, atribuídos à Lacan, "estabelecidos" por J. A. Miller e publicados no Brasil pela Jorge Zahar Editora, traz as três instâncias da segunda tópica freudiana, ich, uber-ich e es, no francês moi,
} 
ou de uma metodologia educacional" (cf. Kupfer, 2000, p. 59). Contudo, ainda que educar situe-se na dimensão do "impossível" e a Psicanálise não prometa a tábua de salvação para formatar a angústia dos educadores diante das vicissitudes do ensinar e do aprender, queremos afirmar que seu escopo teórico não deixa de servir como recurso intelectual para pensarmos outras formas de pedagogizar o fazer educativo. De fato, o pai da Psicanálise em nenhum momento demonstrou interesse em delinear para o pedagogo, fosse este analista ou não, maneiras de mobilizar os conhecimentos psicanalíticos em sala de aula, declarando-se incompetente para tanto, abstendo-se de um campo que deixava a encargo de outros estudiosos. O interesse de Freud pela educação estaria fundamentalmente ligado à teorização sobre a Cultura, em conexão com as ideias que inferiu para compor a teoria psicanalítica, mais precisamente com vistas à possibilidade de tornar o sujeito apto à Cultura, ou seja, socialmente utilizável.

(...) Se esta [a educação] tem o efeito de uma inelutável "repressão" ou de uma "renúncia pulsional", que se mostram em parte "organicamente" determinadas, a educação se acha numa posição estratégica determinante: ela age no próprio cerne da contradição entre a "pulsão" e a Cultura ${ }^{7}$. Disso resulta ter a educação a responsabilidade de assistir à "renúncia pulsional" que constitui o fundamento da civilização e de avaliar por inteiro os efeitos destrutivos - neurotizantes - de uma "limitação pulsional" excessiva, de ideais culturais demasiado pesados que levam as pessoas a viver "em termos psicológicos, acima de suas possibilidades, numa espécie de hipocrisia ${ }^{8}$ (CIFALI ; IMBERT, 1999, p. 12-3, acréscimo nosso).

Não obstante, se nos juntamos àqueles que fazem a crítica ao discurso psicopedagógico hegemônico ${ }^{9}$ e defendemos a possibilidade de uma pedagogia não-ortodoxa, que prescinda dos métodos de ensino, não será para ficarmos esperando psicanalistas, psicólogos, sociólogos, filósofos, médicos ou historiadores indicarem o rumo que se deve tomar na prática educativa. O que não quer dizer negar ou rejeitar a importância desses estudos para o campo da educação. Pois uma coisa são as teorias criadas fora da prática educativa, enquanto outra, queremos crer, são as suposições levantadas por quem, de dentro,

surmoi e ça, em tradução para o português como eu, super-eu e isso, diferente do que propôs a tradução inglesa Standart Edition, publicada no Brasil pela Imago Editora, cuja tradução para os termos se fez pelos latinos ego, super-ego e id. Ver Notas do Tradutor, p. 333, de O Seminário: livro 1: os escritos técnicos de Freud (195354).

${ }^{7}$ Cf. Paul-Laurent Assoun, Freud et les sciences sociales, Paris, Armand Colin, 1993, p. 135.

${ }^{8}$ Sigmund Freud (1915) "Reflexões sobre a guerra e sobre a morte”. In: Obras Completas, Vol. XIV, p. 293-94.

${ }^{9}$ Expressão cunhada por Leandro de Lajonquière para indicar a psicologização hegemônica das práticas pedagógicas, crédula na possibilidade de adequar a educação à realidade espiritual infantil reputada natural. Ver Infância e Ilusão (psico)pedagógica, Vozes, 1999. 
experiencia corpo-a-corpo, palavra-a-palavra a realidade escolar e mesmo a educação informal. A título de exemplo, o sujeito postado nas investigações clínicas dos estudos de Piaget atua da mesma maneira que o sujeito em posição de aluno em meio aos acontecimentos do ambiente escolar? Pois se estão em posições diferentes de transferência em relação ao adulto que os conduz - o primeiro frente ao pesquisador, o outro frente ao educador - , assim como em ambientes distintos, um escolar, outro não, um cercado de colegas, outro não, será que a atuação de ambos seria equânime frente aos experimentos que realizam? Uma coisa é professor e alunos estarem, agirem e atuarem em meio ao caldo escolar, diante de uma situação provocadora de conflito cognitivo ou de conduta social, seja no laboratório, em sala de aula, nos corredores, na cantina, no pátio do recreio, onde for, e outra, que nos parece muito diferente, é postar uma criança diante de um pesquisador com seus materiais pedagógicos, fora do cenário e da dinâmica escolares, e pedir-lhe que execute tarefas envolvendo raciocínios lógico-matemáticos para, em seguida, disponibilizar àquele adulto explicações que lhes são possíveis no momento. O que queremos atentar é para dinâmica transferencial distinta posta em cada situação

Argumentar contra uma prática educativa hegemônica não é empreitada simples, embora possa valer a pena para entreabrir ventanas e fazer soprar ventos com diferentes atrativos. A propósito, não cabe a nós, co-a(u)tores da vida escolar, tentar construir outras formas de levar essa prática social à cena? Aqui, por exemplo, abro uma questão fundamental e que tentarei responder: qual a função de educador? Eis a pergunta que alinhava, ponta-aponta, este escrito, assim como a pesquisa que o antecedeu.

Escancarar a pedagogos, educadores e professores o quanto as certezas pedagógicas são abaladas pelo escopo psicanalítico é uma aposta. Eventualmente, poderá ajudar os pedagogos abrirem mão da ilusão obsessiva de colocar cientificamente todos os pingos nos is em busca da educação ideal - aquela que estaria supostamente ilibada de traumas, falhas e descompassos -, possibilitando o incremento da abertura já enunciada por outros autores em busca de paradigma pedagógico diferenciado da ortodoxia gestada no ideário seiscentista de Francis Bacon, prescrita por Comênio na pragmática Didática Magna, datada de 1657, a qual permanece referência não apenas da prática escolar, como também das pesquisas acadêmicas educacionais, como afirmou Azanha na década de 90. Re-cito:

É claro que não queremos dizer que o pensamento pedagógico de hoje seja um pensamento comeniano. Mas, com relação a alguns pontos, é exatamente isso que acontece. Veja-se, por exemplo, a importância muitas vezes excessiva que se dá no ensino ao papel da observação, da experiência direta. Contudo, o ponto mais importante de influência de Comênio em educação é a 
reivindicação da centralidade do método em todo ensino. Depois de Comênio a preocupação metodológica tornou-se uma constante do pensamento pedagógico até os dias de hoje. Desde o fim do século passado e ao longo deste, com as primeiras investigações educacionais empíricas e a posterior consolidação da pesquisa educacional como prática institucional regular, grande parte da temática dessa pesquisa tem sido a busca de procedimentos de ensino mais adequados e eficazes. O simples arrolamento de alguns nomes notáveis no pensamento pedagógico deste século, como Dewey, Montessori, Decroly, Ferriére, basta para ilustrar a predominância da temática metodológica na educação e, em consequência, na pesquisa educacional. Todos esses autores, embora com preocupações diversas e a partir de orientações diferentes, deram à questão metodológica uma importância central. Até mesmo um autor como Piaget, que a rigor não propôs um método, difundiu-se nos meios educacionais como se preconizasse reformas metodológicas (AZANHA, 1990, p. 38-39).

Para tentar acrescentar um pouco mais daquilo que nos cabe enquanto profissionais e pensadores da educação, emplacados ainda na ambiguidade de eductio e educatio, retomamos o fio de trabalho dando vazão à hipótese inicial de nosso percurso a respeito da função do educador como uma articulação pendular oscilante entre dois polos capazes de reeditar, junto ao educando, registros daquilo que proporcionou ao infans ${ }^{10}$, num determinado tempo de sua infância, condições para advir e se metamorfosear em sujeito.

Mecanismo auxiliar da Cultura na promoção da socialização humana, a educação formal concomitante a outras instituições estaria, desta feita, a serviço de fazer operar e reoportunizar mecanismos subjetivantes originários da família, numa dinâmica entre pulsão, desejo e recalque que se experiência constante, embora de frequência irregular, uma vez que o inconsciente não funciona na cadência periódica de um mesmo tempo, nem em previsíveis oscilações.

Se pudermos pensar a função do educador não como lugar formatado para intervenção e exercício tecnocientífico das metodologias (psico)pedagógicas de ensino conforme o fazer hegemônico da Pedagogia Ortodoxa -, mas como lugar a ser encarnado e sustentado por sujeitos em condições de manejar e serem, até certo ponto, também manejados perante educandos, naquele tipo de vaivém operante situado entre a não interferência e a frustração, seja na Educação Infantil, no Ensino Fundamental, Médio ou Universitário, Educação de Jovens e Adultos e - por que não? -, na de sujeitos da terceira idade, estaremos, por ora, suficientemente satisfeitos.

\footnotetext{
${ }^{10}$ Infans: aquele que não fala.
} 


\section{Educ(a)tio}

\subsection{Retomando o percurso}

Para falar de educ(a)tio, começo pela referência à aula da graduação em Pedagogia, 2002, que literalmente enrolou-me os pensamentos. Ministrada por Marcos Ferreira Santos, era a disciplina Cultura e Educação - Imaginário e Processos Simbólicos. Do pouco que lembro, na verdade quase nada, o significado atribuído a educar, já no final da aula, concluindo o percurso longo e não muito didático daquele dia, parecia dissonante com a ideia do que se costuma professar a respeito da tarefa do educador. Afirmando que a origem latina de educação encontra-se em educere e não em educare, conforme costumeiramente se afirma, a ação de educar não seria tentar levar conhecimento para dentro do aluno, fazendo-o internalizar explicações proferidas pelo professor, mas sim ajudar a fazer sair aquilo que o próprio aluno não sabe que existe dentro de si. Das anotações que pude fazer, resgato e ofereço um pouco do que chamara minha atenção:

(...) Na relação pedagógica há sempre alguém que deseja partilhar um conhecimento versus alguém que deseja apreender (...); O professor se expõe ao ocupar esse lugar que é de referência (...); Ressurge assim a ideia de mestre, mais próxima da ideia de mestre das sociedades orientais (...) o mestre que dá, que mostra o caminho a ser seguido, mas não dita o quê nem como fazê-lo (...); O professor ensina a mesma coisa a todos de uma classe, mas anuncia a cada um uma verdade particular e, se é digno de seu trabalho, espera de cada um uma resposta particular, uma resposta singular e uma realização (GUSDORF, 1963); Um professor dá aula para 30 alunos (...) Sob o anonimato dessa realidade objetiva, há talvez um mestre que deseja ser compreendido (...) e talvez haja 30 discípulos possíveis à espreita de uma palavra de vida que cada um espera seja dita só para si (GUSDORF, 1963); (...) O monólogo aparente da palavra docente decompõe-se na análise, numa multidão de diálogos silenciosos $[e]$ cada um tem seu próprio sentido e valor (GUSDORF, 1963); (...) Esse diálogo surdo [entre professor e aluno] se dá pela vivência de vida de cada um. O sentido da aula está dentro de cada um, por isso, socraticamente, educar seria tirar o que cada um tem em si. $\mathrm{O}$ mestre seria aquele que leva pro caminho que seja nosso, daquilo que sou e ainda não sei. (Informações verbais; citações de Gusdorf oferecidas em apresentação de PowerPoint, acréscimo meu).

- Daquilo que sou e ainda não sei... E que nem o professor sabe... O que é dito entra e sai da cabeça do aluno. O que fica é o que se dá como efeito em nós daquela forma singular que o professor encontrou para ensinar. Aos 30. Um a um. Sem saber exatamente como...

A assertiva sobre educere havia sido lançada de maneira tão sutil e coerente com a exposição do que viera antes que grudou em pensamentos e não me deixou mais em paz, 
porque de alguma maneira, estranha ${ }^{11}$, fazia sentido. Aquilo ficou martelando, remoendo, como se a cabeça estivesse procurando, por si só, maneiras de entender algo paradoxal. Ao mesmo tempo em que aquela observação supostamente crítica parecia antinômica aos preceitos pedagógicos vigentes, servia para exemplificar a crítica de outro professor - este que, não inadvertidamente, mantém-se na orientação de nossos escritos -, ao tecer conexões entre Psicanálise e Educação, indicando a matriz psicológica que há tempos embasa a pedagogia moderna - verdadeira $\operatorname{doxa}^{12}$ que supõe a criança como indivíduo repleto de potencialidades aptas a serem trazidas à tona para serem desenvolvidas através da aplicação adequada de estímulos (psico)pedagógicos ${ }^{13}$. Novamente de maneira estranha, a esse outro professor, a origem latina de educar encontrava-se não em educere, mas em educare ...

- Ai ai ai ...

\begin{abstract}
${ }^{11}$ Estranho: "Estranheza (sentimento de estranheza): sentimento de mal-estar e de esquisitice, diante de um ser ou objeto familiar e perfeitamente conhecido (...) depois de S. Freud (...) o que [os psicanalistas] chamam de "inquietante estranheza" seria provocada pelo aparecimento no real de alguma coisa que lembraria demasiado diretamente o mais íntimo, o mais recalcado. Observemos, ainda, que o sentimento de estranheza parece particularmente forte, sempre que o mecanismo de duplicação imaginária parece prevalente (tema literário do duplo). (B. Vandermersch, in: CHEMAMA ; VANDERMERSCH, 2007, p.133, acréscimo nosso)"; P. Salvain, por sua vez, acrescenta: “(...) são as ideias súbitas e os impulsos involuntários, seus hóspedes estranhos, que atestam que o "eu não é senhor em sua própria casa" ( Freud: "Uma dificuldade no caminho da psicanálise", 1917). Consequentemente, é o recalcado inconsciente que é considerado como "terra estranha interna" (Freud: $31^{\text {a }}$. Das "Novas conferências, de 1932). Estranho (Fremde) é portanto esse lugar da Outra Coisa (das Ding) que habita o sujeito e permanece fora do seu alcance. A partir disso, até o mais familiar pode voltar a obsedar este último de maneira enigmática e assustadora, suscitando o sentimento da "inquietante estranheza" (das Unheimliche, 1919). (...) Freud atribui esse efeito de estranheza ao retorno do recalcado, bem como à reativação de crenças aparentemente superadas. (...) Em outras palavras, os desejos afastados e os pensamentos renegados ou rejeitados são projetados sob forma de forças estranhas ao sujeito. (...) em Lacan, esse lugar estranho é o do "objeto a", que o analista representa. Maravilha ou dejeto, ele é o produto do deslocamento e da condensação do gozo faltante. Tela do inconsciente, constitui um ponto de fixação mas intervém no lugar onde o sujeito é convocado a vir: aí onde a verdade da estranheza consegue se deixar pensar" (KAUFMANN, 1996, p. 174).
\end{abstract}

12 Doxa: "Sistema ou conjunto de juízos que uma sociedade elabora em um determinado momento histórico supondo tratar-se de uma verdade óbvia ou evidência natural, mas que para a filosofia não passa de crença ingênua, a ser superada para a obtenção do verdadeiro conhecimento" (Dicionário Houaiss da Língua Portuguesa, p. 1082).

13 “A ilusão (psico)pedagógica, hoje hegemônica, faz com que nos agarremos à crença de podermos adequar a intervenção do professor à realidade cognitiva, espiritual da criança. Isso é um grande fantasma, porque encena a possibilidade de um suporte pedagógico que respeite as diferenças da criança, quando não se trata disso, mas justamente de fabricar as diferenças. O professor deve colocar suas diferenças, enquanto dá tempo ao tempo, esperando os efeitos de sua ação. (...) Por isso o papel do professor é uma questão de autoria, não de método, nem de didática" (LAJONQUIÈRE, Informação verbal proferida durante a disciplina Psicanálise e Educação: Para uma análise do cotidiano escolar, em 2002, FEUSP). Em Figuras do Infantil: A psicanálise na vida cotidiana com as crianças, da Editora Vozes, 2010, o autor desdobra essa questão, dando continuidade à pesquisa dos trabalhos anteriores. 
Afinal, a origem etimológica de educar estaria em educare ou educere? Paradoxo cruel... porque uma coisa é fazer entrar, a outra, fazer sair, fazer entrar ou fazer sair, fazer entrar ou sair, entrarsair, entrarsair, entrarsairentrarsairentrarsairentrar....!!??.. Que tortura ... a Cabeça não parava de repetir as tais palavras, além do muito e mais, aludindo ao erótico... que fantasia!, que lugar para pensar uma coisa dessas, em plena Faculdade de Educação, Professora Ana Carolina?!

- Para cabeça!...,

Mas a Cabeça, não parava ..., então deixei que o tempo passasse, os créditos conquistasse, burrocráticos Estudos Independentes se contabilizassem, até em inícios de 2004, no último ano da graduação, pedir ao "professor de Psicanálise" se poderia orientar a monografia optativa de conclusão de curso. Gostaria de pensar e escrever a respeito das Metodologias de Ensino porque, embora vivesse de aulas há mais de 22 anos, trabalhando junto a crianças e adolescentes ${ }^{14}$ anoréxicos frente aos conhecimentos oferecidos pelo currículo escolar, em geral fechados no saco de gatos das ditas dificuldades de aprendizagem, ou na entropia da inibição intelectual - isso que só pude e aceitei nomear após a leitura do trabalho de Ana Lydia Santiago (2000) - , nunca tivera interesse em ler a respeito dos métodos de ensino, nem de vertentes do universo psi em campos da pedagogia; não sabia nada da psicogênese epistêmica proposta por Piaget, menos ainda das zonas proximais de desenvolvimento de Vygotsky, embora obviamente tivesse inventado diversos "truques" para lidar com os alunos e situações de aula na tentativa de fazer com que aprendessem algo da Álgebra e da Geometria, da Gramática e de Redação e, por vezes, também, da História, das Ciências, Geografia ou Inglês.

- Ah, como seria interessante trocar figurinhas com um certo Prof. Jacotot ${ }^{15} ! \ldots$

Então, para o começo do trabalho anterior, o que retorna do recalcado como primeiro fio a ser puxado na investigação? ... O educar entre fazer entrarsair, é claro, porque a cabeça da sujeita, por ora acadêmica, parecia ter prazer também com aquele paradoxo, motivo pelo qual partiu em busca dos dicionários etimológicos. Queria chegar ao educar de fazer sair, que Ferreira havia mencionado, já que na maioria dos livros a única origem atribuída

\footnotetext{
${ }^{14}$ Cerca de 30 alunos com idades entre 9 e 14 anos passam por minhas aulas a cada ano, apresentando inúmeras dificuldades escolares.

${ }^{15}$ Leitura inestimável a quem não se prende ao ensino metodológico. De Jacques Rancière, O mestre Ignorante: cinco lições sobre a emancipação intelectual. Belo Horizonte: Autêntica, 2004.
} 
estava mesmo em educatio, usado por Lajonquière: ação de nutrir, criar, amamentar, cuidar, ensinar, instruir, cultivar uma criança, ou seja, fazer entrar. Depois de muito procurar, na verdade tendo deitado vistas várias vezes sobre o tesouro que procurava, sem aperceber-me no entanto que ali estava, pedi ajuda a outro professor, Jean Lauand, também de Filosofia, falador de muitas línguas. Queria dele saber se sabia a origem do termo educar, o que me respondeu, com simplicidade e elegância, que a origem podia ser atribuída, ambiguamente, tanto a educatio/educare, quanto a eductio/educere, mandando-me de generoso presente, a seguinte citação:

Dos interpretaciones se dan de la etimología de educación (...). Las dos acepciones tienen sentido. Según la primera [educatio], la educación es tanto como alimentación, recibir algo de fuera para incorporarlo a nuestro organismo. Según la segunda [eductio], educación es desarrollo, despliegue de fuerzas interiores. $\mathrm{Y}$ ciertamente la educación puede ser ambas cosas: enriquecimiento personal que viene del exterior y desenvolvimiento de las propias potencias o disposiciones (Dra. Pastora Moreno - Profesora de la Facultad de Ciencias de la Información de la Universidad de Sevilla).

Se para avançar em seus estudos, sabe-se, Freud retomava pontos e aumentava contos, tomo liberdade de fazer parecido. Pois de fato, nem sempre o cognitivo encontra os encaixes para as peças que estão ao nosso dispor, flutuando na massa do desequilíbrio cognitivo provocado pelo que parece diferente, ainda não entendido, ainda não construído enquanto conhecimento. Embora crescidos e razoavelmente bem alfabetizados, continuamos precisando de tempo para apreender e juntar as coisas, como literalmente acontece com frequência às crianças diante dos desafios escolares. Sendo assim, no escrito passado, chegamos a resvalar em educ(a)tio, sem o saber, e nos mantivemos longe de discutir esse que agora nos parece o G da questão. Ou melhor, o $a$. Em 2005, para sermos mais precisos, nossas inflexões haviam chegado aqui:

(...) Para essa Pedagogia "psicologizada", educar consistiria em fazer o papel de ducto, de cano, túnel ou passagem, através do qual o indivíduo adentra ao mundo dos homens. Sendo assim, o processo de educação permitiria ao filhote considerado já um ser humano não pronto - mas semi-pronto passar pelas entranhas da cultura e percorrer o inexorável caminho da socialização. Educar [como eductio] seria, por conseguinte, fazer emergir o que já é e está ali, real e palpável, como um submarino do qual podemos ver, a princípio, apenas o pequeno periscópio, embora tenhamos certeza de sua concretude submersa. Desta feita, os educadores agiriam como promotores de tal passagem, agindo sobre o indivíduo como propulsores estimulantes, a fim de despertar o que existe de humano em potencial no ser, naturalmente apto a se desenvolver. Em Infância e Ilusão (Psico)Pedagógica, Lajonquière esmiúça a questão e procura demonstrar como a Pedagogia acaba 
"renunciando à educação ao insistir no ajustamento de suas intervenções a supostos estados naturais das capacidades dos escolares".

Pensemos, agora, no outro sentido de educar [como educatio], aquele que dá a ideia de fazer entrar, de trazer alimento, de cultivar, faz crescer, criar. Sem muito esforço chegamos à ideia do engravidar, do inocular, do plantar sementes - e porque não ideias e palavras? -, do transmitir marcas simbólicas, diria o psicanalista. Pensando assim, educar ganha ares mais masculinos, diferente da feminilidade do ducto maternal, quase vaginal, descrito acima. Um educar mais próximo do movimento que procura brechas, buracos, vazios, para fazer-se penetrar e germinar no sujeito algo que sirva de alimento ao desejo. Desejo de complemento, de obturação, na constante busca de reviver a satisfação total dos primeiros cuidados recebidos após o nascimento. Experiência prazerosa, quiçá vivida, porém para sempre perdida, impossível de ser reeditada por igual, já que no momento seguinte à realização de um desejo o mesmo mostra-se fugaz e volátil, redirecionando-se para novas empreitadas, novos anseios, porque aos homens - devido à linguagem, dizem os psicanalistas -, não é dada a completude da condição natural vivida pelos animais, estes sim seres inteiros e plenos como deve ter sido todo mamute e será para sempre cada beija-flor. Haverá algo mais inteiro, certo, previsível e completo do que uma galinha? Eis um indivíduo posto. Um organismo completo: a galinha. Já o homem aponta a Psicanálise -, diferente da condição animal, não desfruta da confortável e cômoda determinação biológica simplesmente porque é movido por aquilo que Lacan chama de falta-a-ser, motivo pelo qual a questão do desejo está no centro da teoria psicanalítica (CAMARGO, 2006, p. 38-9).

Este havia sido, em suma, o ponto em que pudemos chegar no trabalho anterior, sem termos encontrado meios, na época, de pensar algo com maior estofo a respeito daqueles "ares mais masculinos" de educatio, e da "feminilidade do ducto maternal, quase vaginal" de eductio...

Como boa surpresa, a monografia foi aceita para publicação em livro e logo a seguir o período para esta pesquisa dissertativa teve início. E como não havia de ser diferente, para o novo recomeço, retornando do recalcado mais uma-duas vezes, a cena primeva, do justo entrarsairentrarsairentrarsair ...

- Ió! Ió! Dentro desse teatro Dioniso agora está...

Segurem o tirso na mão direita e ergamos o pé. Saltemos! Dancemos por

Brômio, nosso deus tauricórnio.

Sim, eis que volta, mais por outra vez a natureza de $A B a c a$, revelada em monólogo apresentado no começo da década de $90^{16}$ ? Possivelmente... e por filosofia não negá-la,

\footnotetext{
${ }^{16}$ A Baca (1991). Monólogo escrito e representado por esta autora para a primeira Consagração à Primavera, cujos diretores teatrais Rodolfo Garcia Vásquez e Ivan Cabral re-nomearam, alguns anos à frente, como Satyrianas, evento anual, que tem lugar na Praça Roosevelt, centro de São Paulo, com apresentações de teatro, circo, música, artes plásticas e afins, congregando nichos diferentes da intelectualidade, entre os quais, não por acaso, psicanalistas com a pena voltada também a peças teatrais.
} 
mesmo porque não nos é possível evitar, pegamos o tirço, as heras, o vinho, os cantos em homenagem a Dioniso e seguimos em frente, dançando em meio aos campos "pentêuticos" da Pedagogia. Insatisfeita, como de sempre, a cabeça nos fez voltar ao encalço etimológico de eductio, quando finalmente encontramos - porque dessa vez enxergou-se - Educère, leitor, educère... Peguemos a lente de aumento e abramos os ouvido para o que trazem dicionários quando tratam de eductio/educere, a ação de deitar, de lançar para fora, via duto:

Educo, eductum, educere: Tirar de, retirar, levar para fora, intimar, levar a juízo; parir, produzir; criar, nutrir, manter, sustentar; eleger, exaltar; despejar, esvaziar; trazer de cima; passar (o tempo), empregar; subtrair; furtar. Educere gladium e vagina, Cícero: Tirar a espada da bainha (QUICHERAT, L. 1993, p. 405).

!!! ... Agora, sim, podíamos entender porque a ambiguidade discreta, provocada pela sutileza de um pequeno a que ora está, ora não - sempre isso de "pequeno $a$ " - para nós revelara-se tão impregnante, tão estranha: eductio, educatio, eductio, educatio, eductioeducatioeductioeducatio...

- ... Que irritação!,... Mas é claro,... para você deve ter passado desapercebido como a nós tantas vezes!...Volte lá, você que nos lê!... Educar tem a ver com tirar a espada da bainha, educere gladium e vagina! ... Ui! Cuidado, estamos na Academia, Senhora Cabeça de professora pedagoga...entarsairentrarsairentrarsair...

Assim, levando em conta ambas as acepções do termo, educar remete ao movimento pendular de fazer entrar e fazer sair; fazer embainhar a espada - objeto fálico - mas também desembainhá-la; pêndulo cujo vértice não parece outro senão o objeto causa de desejo, o pequeno $a^{17}$, lábil, fantasístico, que nos faz pensar o educar mais como a arte de promover e

\footnotetext{
${ }^{17}$ Sobre o objeto pequeno $a$ : "Objeto causa de desejo. (...) O objeto a não é um objeto do mundo. Não representável como tal, só pode ser identificado sob a forma de "fragmentos" parciais do corpo, redutíveis a quatro: o objeto da sucção (seio), o objeto da excreção (fezes), a voz e o olhar. (...) Esse objeto é criado nesse espaço, nessa margem que a demanda (isto é, a linguagem) abre além da necessidade que a motiva: nenhum alimento pode "satisfazer", por exemplo, a demanda do seio. Ele se torna mais precioso para o sujeito do que a própria satisfação de sua necessidade, pois ele é condição absoluta de sua existência enquanto sujeito desejante. Parte destacada da imagem do corpo, sua função é de suportar a "falta a ser" que define o sujeito do desejo. Essa falta é substituída, como causa inconsciente do desejo, por uma outra falta: a de uma causa para a castração. A castração, isto é, a simbolização da ausência do pênis da mãe, como falta, não tem causa, a não ser mítica. Ela depende de uma estrutura puramente lógica: é uma representação, sob forma imaginária, da falta no Outro (lugar de significantes), de um significante que responde pelo valor desse Outro, desse "tesouro dos significantes que garante a verdade (Bernard Vandermersch, in: CHEMAMA; VANDERMERSCH, 2007, p. 278). “(...) Esse é o conceito que mais sofreu modificações ao longo da trajetória de Lacan. Mas ele sempre indicará o objeto causa do desejo e não objeto do desejo, já que o desejo não tem objeto. "Pequeno a" é causa porque funciona como uma espécie de matriz transcendental para a constituição dos objetos nos quais o desejo se alienará. Todos os objetos investidos pelo desejo serão modulações de um único objeto cujo estatuto é o de uma fantasia fundamental" (SAFATLE, Vladimir, in Glossário Lacanês, Folha Mais!, 2001). Disponível em: http://webcache.googleusercontent.com/search?q=cache:fRweinU52esJ:www.oocities.com/vladimirsafatle/vladi 006.htm+gloss\%C3\%A1rio+lacan\%C3\%AAs\&cd=2\&hl=pt-BR\&ct=clnk\&gl=br . Acesso em 26/11/2010.
} 
sustentar a articulação entre educatio e eductio - educ(a)tio, grafia precipitada durante a escrita desta dissertação -, do que a tecnocrática mobilização docente advinda da apropriação de métodos e recursos didático-psicopedagógicos.

- Sê bem vindo! Adentre e beba essa taça de vinho tinto. Evoé!

\subsection{Educar-enodar-enlaçar: reedição do trígono edipiano}

Eu não sou nem eu nem sou o outro

Sou qualquer coisa de intermédio:

Pilar da ponte de tédio

Que vai de mim para o Outro

Mário de Sá Carneiro (1890-1916)

"Um animal inacabado", assim o educador argentino Estanislao Antelo (s.d.) refere-se ao homem, dizendo "Tomo como ponto de partida a afirmação de que educar é uma das formas de conjugar o verbo ser", porque a plenitude do "ser humano" é ausente, o que faz da causa aparente de qualquer busca educacional ser identitária, uma vez que o sujeito humano tem acesso a seu ser, necessariamente, através de outros. Ao citar Ernesto Laclau, Antelo faz suas as palavras inspiradas em Freud e Lacan:

Se necessito identificar-me com algo é porque não sou, desde o começo, uma identidade plena. Estes atos de identificação são pensáveis somente como resultado da falta no interior da estrutura e mostram o vestígio permanente daquela. (...) Manifestação mais precoce - diz Freud - de um enlace afetivo com outra pessoa. [Assim] Freud nos permite agregar à série carência, falha, falta, a palavra alteridade. Seu pensamento avança em direção a explicar o que, no social, estabelece laço. Daí a reiteração surpreendente da palavra enlace. Enlaçar, fundir-se, coesão. O modelo dos laços afetivos, será o amor. Uma massa será aquilo que não cessa de enlaçar-se e desenlaçar-se. Identificação será o nome dessa experiência, primordial, precoce, repetida e falha, de constituição do ser (Acréscimo nosso).

A educação está no cerne da noção psicanalítica de sujeito porque é através dessa prática social discursiva que acontece a imersão da criança na linguagem, possibilitando a ela fazer laço social para adentrar no universo humano (cf. Kupfer, 2001, p. 35). Sendo assim, educar não apenas socializa o homem, como o humaniza. A diferença de um recém-nascido humano para uma peça de carne - de carona na provocação de Lacan - é que os 
descendentes da picanha não têm romance familiar para contar, inserindo-se como parte do próximo capítulo geracional simplesmente porque não habitam o campo da palavra, tampouco acessam a Lei da interdição do incesto e do assassinato, entre outros "nãos".

Ao discorrer sobre a educação, Jerusalinsky utiliza um termo que faz eco a Antelo e nos ajuda a pensar o pendular de educ(a)tio. Para ele, a educação é um ponto de enodamento que não opera por saber instintivo, mas por saber social que “... simboliza a demanda - dando seu lugar ao pai - alterizando o sujeito de um modo arbitrário e radical, impondo ideais que o arrastam muito longe do paraíso materno" (In: CALLIGARIS et alli, 1994, p. 19). Se isto vale para a educação em geral, inclusive a formal, nela mantém-se a estrutura do trígono edipiano, reeditada com outros personagens encarnados nos lugares das funções.

Aprofundar a reflexão sobre esse enodamento reeditável nos interessa porque permite pensar a função do educador não como um fazer adaptativo, mas como ação subjetivante via construção imaginária e simbólica do eu - estrutural a esse saber-fazer - , contrapondo o registro relacional ${ }^{18}$ comumente aceito entre professor e aluno a uma prática discursiva de enlaçamento entre sujeitos, na qual o adulto se oferece para passar conhecimentos e normas da cultura, ao mesmo tempo em que se expõe à desproporção do embaraço identitário transferencial. Transferência, identificação, alienação, separação, interdição, palavras-conceito interligadas, de forma ou outra, à trinca em jogo da filiação simbólica inaugural, mãe-pai-filho, além do vetor fálico que, faz-de-conta, deixamos para depois...

Em Freud, temos que a passagem da criança pela metáfora edipiana permite, através da proibição do incesto veiculada pelo pai - e possibilitada pela mãe -, interditar a célula narcísica mãe-filho através da qual ambos se servem e se completam em satisfação enquanto objetos de amor. Educar é civilizar, afirma o autor em O Mal-Estar na Civilização, justamente quando auxilia na direção da sublimação sexual, trabalhando a favor do recalque, ajudando a redirecionar a pulsão sexual para fins socialmente valorizados. No mesmo sentido,

\footnotetext{
${ }^{18}$ Relação no sentido de "rapport", de proporção, de adequação, de que haja possibilidade de encaixe perfeito, de complementação, acoplamento. A ideia de relação, e isto não deixa de ser um chamado de atenção feito por Lacan, pressupõe que haja a possibilidade de complementaridade, de se fazer um a partir de dois, de ser possível encontrar o objeto adequado ao desejo, o que nunca ocorre, nem mesmo, na relação sexual devido à radical dissimetria existente entre os dois modos de identidade sexual. E, tal como não há "relação sexual" possível, transportamos a máxima lacaniana de difícil entendimento para o campo educativo, para mostrar o que nos parece recalcado pela ilusão psicopedagógica vigente, precisamente, a não simetria entre o real do educando e o real do educador. Se Lacan afirma, provocativo, que "Não há relação sexual", parafraseamos e dizemos que, no campo educativo, não há como haver "relação pedagógico-educacional".
} 
Lacan aponta o corte como fundamental na teoria da metáfora do espelho ${ }^{19}$. Através dele - e só dele - a criança desaliena-se da imagem imposta pela mãe por intermédio da falta imposta pelo pai - ou melhor, pelo agente da função paterna - quando então, inoculada pelas marcas simbólicas do desejo parental, o infans ganha acesso à ordem simbólica do discurso, da cultura e da falta-a-ser ${ }^{20}$ que lhe permitirá, dizemos nós, sofrer uma educação socializadora e humanizante ${ }^{21}$, não exatamente "adaptativa". Por conseguinte, talvez possamos entender o funcionamento do drama edípico como adágio, dínamo da dinâmica educativa, uma vez que foi só em decorrência dessa travessia primeira que o sujeito pôde (ou não) iniciar-se na socialização, registro através do qual, em grandes chances, seguirá funcionando.

Ainda que o educador não seja pai ou mãe do educando, embora também possa ser, algo do quebra-cabeça edípico precipita e faz reflexo no (des)encontro entre esses sujeitos, o que nos levou a perguntar até que ponto um professor não pode ocupar, mesmo que fugaz e de forma indeterminada, simbolicamente, o lugar e a função do desejo materno e/ou do "não" do pai via isso que Lacan chamou de "palavra plena"? Porque se o advir de um sujeito, no sentido que os psicanalistas dão ao humanizar do infans, não pode prescindir de um processo de alienação (em relação a alguém com atributos de uma "mãe"), seguido de interdição/castração/corte (realizada por um "pai" e pela linguagem), ou seja, se a socialização/humanização não pode prescindir daquilo que compete às funções parentais, o professor enquanto agente da função de educador não parece articular, em reedições, exatamente esse lugar de pêndulo entre as duas funções em relação ao terceiro eixo, este que deve sofrer os efeitos de uma tentativa de educação? Cila e Caribde, Cila e Caribde, Cila e

\footnotetext{
${ }^{19}$ Estádio do Espelho: expressão cunhada por Lacan para designar um momento psíquico e ontológico da evolução humana, durante o qual a criança antecipa o domínio sobre sua unidade corporal através da identificação com a imagem do semelhante e da percepção de sua própria imagem num espelho (ROUDINESCO ; PLON, 1998, p. 194).

${ }^{20}$ Falta-a-ser: Segundo Vladimir Safatle, "Ao articular desejo e negatividade, Hegel vincula-se a uma longa linhagem, que remonta a Platão e compreende o desejo como manifestação da falta. No entanto, já em Hegel, esta falta não é falta de algum objeto específico, vinculada à pressão de alguma necessidade vital, tanto que o consumo do objeto não leva à satisfação. A falta é aqui um modo de ser do sujeito, o que levará Lacan a falar do desejo como uma "falta-a-ser". Um modo de ser que demonstra essa indeterminação fundamental do sujeito moderno, essa liberdade manifestada pela ausência de essência positiva que faz com que ele nunca tenha correlação natural com atributos físicos, nunca seja completamente adequado às suas representações, imagens e papéis sociais" (SAFATLE, 2007, p. 33-4).

${ }^{21}$ Em dissertação de Mestrado sobre transferência, Elisabete Monteiro escreve: "Esta permanente incompletude (ou completude perdida, para sempre, da célula narcísica), a impossibilidade de satisfação, isto que desde sempre resta da diferença entre as experiências, a eterna busca pelo reconhecimento, a procura de fazer-se amar, tornarse amável pelo Ideal do Ego, procurando constituir-se no Ego Ideal, isto que falta para que o sujeito triunfe, Lacan chama de objeto (pequeno a), elemento causa do desejo do sujeito, ponto de falta onde o sujeito tem de se reconhecer, e se tornou um conceito tão central na teoria de Lacan quanto o conceito de inconsciente na teoria de Freud. É o objeto $a$ que faz o sujeito "apostar" na transferência" (MONTEIRO, 2000, p. 66-67).
} 
Caribde nas palavras de Freud ... Mesmo porque, quando um aluno (seja ele criança, adolescente ou adulto) se lança ou é enlaçado num movimento identitário e transferencial a professores/educadores, é sabido que haverá grandes chances de vir tentar (re)acertar com estes supostos adultos as contas pendentes "edipianas" abertas no seio familiar. Sobre isso escreveu Freud em “Algumas Reflexões sobre a Psicologia do Escolar”:

A natureza e a qualidade das relações da criança com as pessoas do seu próprio sexo e do sexo oposto, já foi firmada nos primeiros seis anos de vida. (...) As pessoas a quem se acha assim ligada são os pais e irmãos e irmãs [assim como avós, babás, pessoas que ajudam nos cuidados com o infans]. Todos que vem a conhecer mais tarde tornam-se figuras substitutivas desses primeiros objetos de seus sentimentos. Essas figuras substitutas podem classificar-se, do ponto de vista da criança, segundo provenham do que chamamos 'imagos', do pai, da mãe, dos irmãos e irmãs e assim por diante. (...) De todas as imagens (imagos) de uma infância que, via de regra, não é mais recordada, nenhuma é mais importante para um jovem ou um homem que a do pai. (...) Cedo, porém, surge o outro lado da relação emocional (...) torna-se um modelo a ser imitado, mas também a ser eliminado para que possamos tomar o seu lugar. (...) Na segunda metade da infância dá-se uma mudança. De seu quarto de criança o menino começa a vislumbrar o mundo exterior e não pode deixar de fazer descobertas que solapam a alta opinião original que tinha sobre o pai. (...) É nessa fase (...) que ele entra em contato com os professores (...). Este homens, nem todos pais na realidade, tornaramse nossos pais substitutos. (...) Transferimos para eles o respeito e as expectativas ligadas ao pai onisciente de nossa infância e depois começamos a tratá-los como tratávamos nossos pais em casa. Confrontamo-los com a ambivalência que tínhamos adquirido em nossas próprias famílias e, ajudados por ela, lutamos como tínhamos o hábito de lutar com nossos pais em carne e osso. A menos que levemos em consideração nossos quartos de crianças e nossos lares, nosso comportamento para com os professores seria não apenas incompreensível, mas também indesculpável (FREUD, 1996 [1914], V. XIII, p. 248-250. Grifo e acréscimo nosso).

Eis porque a noção de enodamento nos interessa tanto. Se pensarmos a função do educador como um posicionar-se e ser posicionado por educandos exatamente nos lugares simbólicos ou imaginários de um "pai" e de uma "mãe", o papel do educador acaba por promover, também, o que é da ordem de uma filiação ${ }^{22}$ simbólica. E não importa se a classe

\footnotetext{
${ }^{22}$ Philia : "O termo filiação é comum ao direito, à antropologia e à psicanálise. Designa a regra em virtude da qual o indivíduo adquire sua identidade social e se inscreve num processo de transmissão de tipo patrilinear ou matrilinear" (ROUDINESCO ; PLON, 1998, p. 238). Lembramos, ainda, que filiação deriva do grego philia: “(...) coube a Aristóteles o merecimento de ter resumido o que de melhor o pensamento grego nos legou sobre o amor de amizade, sobre a philia. Na Cultura Ocidental, a palavra $\varphi \imath \imath \iota \alpha$ geralmente foi traduzida por "amizade". Todavia, nos escritos da Grécia Arcaica, o termo tinha uma conotação semântica muito mais ampla e era empregado para traduzir um vínculo de união ou de interesse entre os homens, quer este fosse devido ao sentimento de mútua simpatia, quer fosse fruto de uma vantagem específica, ou até mesmo do próprio acaso. Daí porque eram amigos ( $\varphi$ ı o i): os camaradas de jogo, os colegas de viagem, os companheiros de navegação, os
} 
desse professor tenha um ou 70 alunos. Ao se oferecer para ocupar esse lugar, ainda que não o saiba, e geralmente isso não se sabe, de qualquer maneira estará entrando num palco onde de costume o olho do furacão costuma passar, em uma dinâmica de enodamentos que não operam por instinto, conforme afirmou Jerusalinsky, senão através da autoria, como diz Lajonquière e do estilo, dizemos nós. Em acenos que fará empunhando objetos da Cultura por ele valorizados, cabe por profissão ao professor/educador, numa espécie de reedição do que ocorreu no tempo primordial da educação, ou melhor, nos primeiros tempos da educação de uma criança, investir de desejo o educando, como faz uma mãe, para depois “... alterizar o sujeito de um modo arbitrário e radical", como faz um pai, homem de uma mulher.

Via identidade, o eu é composto de imagens pregnantes que lhe servem como alimento. Educatio. Contudo, não imagens quaisquer. O eu percebe apenas aquelas em que se reconhece, imagens que, de longe, ou de perto, refletem o que já está, ainda que sem saber:

Pregnância é uma das tantas modalidades que o sentido adota. Não o sentido em sua acepção linguística de ser dentro de um signo, mas em sua acepção psicanalítica de ser o efeito produzido quando uma forma imaginária - seja qual for - provoca prazer de nos ajustarmos a ela e, acima de tudo, de nos reconhecermos nela. Chamamos pregnantes a todas as formas que adquirem sentido para o eu" (NASIO, 1995, p. 21).

De Lacan temos a precisa informação:

No artigo sobre $O$ Eu e o Isso, (...) Freud escreve que o eu é feito da sucessão das suas identificações com os objetos amados que lhe permitiram tomar a sua forma. O eu é um objeto feito como uma cebola, poder-se-ia descascá-lo, e se encontrariam as identificações sucessivas que o constituíram (LACAN, 1953-1954, p. 198).

A ideia freudiana de que o eu deveria ser entendido como uma estratificação concêntrica do material psíquico ${ }^{23}$ faz sentido também em Lacan, porque no centro desse modelo é um vazio, como cebola que é feita só de camadas, sem caroço. No caso do eu, camadas imaginárias feitas de imagens pregnantes - aquelas e só aquelas, nas quais o eu se reconhece. Para depois sair: Eductio.

Reconhecer-se não quer dizer que 'isso é o mesmo que eu', mas que o objeto desperta prontamente um sentido ligado ao eu. E sentido quer dizer: ajustar-se à imagem desse objeto, reconhecer na imagem desse objeto algo que está ligado a minha história, a minha impressão, a minha sensação. (...) Todo reconhecimento de eu nessas imagens pregnantes vem a ser, em última

colegas de armas, os associados no comércio, os pais, esposos, irmãos, parentes e os cidadãos em geral (ROCHA, 2006).

${ }^{23}$ In : Psicoterapia da Histeria (Freud [1893-1895], p. 301, V. II) 
instância, um reconhecimento enquanto eu como ser sexual (NASIO, 1995, p. 22).

Se para nós o trabalho do educador tem participação, por meio de enodamento e pregnância identitária, na continuidade do processo de subjetivação inaugurado no âmbito familiar, vemo-nos compelidos a adentrar conceitualmente nas funções materna e paterna na tentativa de tecer e acrescentar alguns pontos na conexão entre os campos da Pedagogia e da Psicanálise, justamente em nome de outras "práticas [pedagógicas] de subejtivação da modernidade", como apontamos na primeira epígrafe deste trabalho, através da citação de Dunker. Acrescentando ao estofo bibliográfico alguns fios retirados da literatura, do cinema e das artes plásticas, tomaremos a liberdade de trazer à presença um pouco do universo roseano de Miguilim; do menino da Infância de Graciliano Ramos; de Helen Keller e sua preceptora Anne Sullivan, em filme e livros; do eu lírico de Manoel de Barros em Memórias Inventadas na série autobiográfica sobre primeira, segunda e terceira infâncias; de algumas canções da MPB, que nos compõe; e, finalmente da tela de Gustave Courbet, A Origem do Mundo, este que se transformou em nosso ponto de capitonê.

Contudo, por que bordar as ideias de tal maneira nisso que toma corpo como espécie de escrito-bricolagem com intenções acadêmicas, exercício que mais parece perambulagem e vaga-mundear, não muito comum por estas bandas pedagogas? Porque, responde eujemoi, interessa-nos nada menos que a flanância, a vadiagem, paragens entre ideias-e-imagens para um Outro pensar pedagógico, inoculado um dia, talvez, por termos nos deitado em breves atenções nas categorias de primeiridade, secundidade e terceiridade da semiótica de Pierce, nos tempos de iniciação científica ${ }^{24}$, quando e onde se deu a chance de aprendermos que tanto a forma, como a estética de continente e conteúdo são capazes de fazer diferença na mente de quem lê - seja leitura de palavras, imagens, cardumes ou nuvens, já que tudo que há no mundo, segundo aquele autor, é passível de ser lido e multihiperinterpretado. A intenção, aqui, pode-se perceber, é também enodar, lançar o laço, enlaçar...

\footnotetext{
${ }^{24}$ Um olhar semiótico sobre a ilustração nos livros de literatura infantil. Trabalho de Iniciação Científica, com bolsa do CNPQ, realizado junto ao Laboratório de Literatura Infantil da Faculdade de Educação da Universidade de São Paulo, sob orientação da Profa. Mary Julia Dietzsch. Não publicado.
} 


\subsection{Qual o tempo para um sujeito advir, formar-se, vir-ar-ser?}

Em um texto intitulado A Questão do Sujeito: Construção, Constituição e Formação, Dunker afirma ser questão não exatamente uma pergunta, mas uma passagem ou transmissão da palavra. De origem latina quarere, a conotação de querer, procurar, buscar conservarse-ia no sentido lógico do termo questão. "Uma questão, é um ato linguístico que consiste em enunciar algo denotando, quer pela entonação, quer pela forma gramatical, quer pela pontuação, que se pede algo a alguém que a enunciação seja completada",25 (DUNKER, 2002, p. 20). É uma incitação ao dizer, convidando o outro a tomar uma posição, manifestando-se como sujeito. Mas se ao final da Idade Média, resume o autor, a quaestio surge como gênero literário e impõem-se junto ao nascimento das primeiras universidades como uma espécie de exercício pedagógico ou método de aprendizagem baseado na alternância de objeções e refutações, permitindo a participação de bacharéis e mestres em disputas verbais e exposições compartilhadas de seus trabalhos pessoais, depois do século XV questão já designa assunto, ou seja, tema ou ponto de discussão que ainda não está resolvido.

Expressa, portanto, a situação em que, os que pelo tema se interessam, não encontram consenso ou conciliação de teses. Daí os termos subject em inglês e sujet em francês significarem, ambiguamente, tanto assunto, quanto alguém que fala de um assunto. Inversamente, diz-se assuntar, em português, no sentido de convocar alguém a falar, incitar a dizer (Idem, ibidem, p. 20).

Assim, o autor convoca o leitor ao exame comparativo de três perspectivas de entendimento para a questão do sujeito: construção, constituição e formação, levando em conta a afirmação de Foucault ${ }^{26}$ sobre a importância de reconhecer a contradição originária da psicologia. Trata-se de um texto belo, denso, recheado de referências, na procura por assinalar proximidades, tensões e afinidades entre aquilo que a tradicional divisão disciplinar, metodológica e geométrica da psicologia costuma esconder, mesmo que na penumbra de paradigmas. Os temas que interrogam a psicologia interna e constitutivamente permitem, de acordo com Dunker, conceber o sujeito como um nó articulado entre três linhas de investigação, distintas, mas solidárias. Uma se volta à questão do sujeito, tomada como

\footnotetext{
${ }^{25}$ LALANDE, A. Vocabulário Técnico e Crítico da Filosofia. Rés: Lisboa, 1997.

26 "O futuro da psicologia não estaria, doravante, no levar a sério estas contradições, cuja experiência, justamente, fez nascer a psicologia?". Foucault, M. A Psicologia de 1850 a 1950. In: Foucault, M. Problematização do sujeito: psicologia, psiquiatria e psicanálise. Rio de Janeiro: Forense Universitária, 1999, Coleção Ditos e escritos, p.139.
} 
descentramento, divisão ou contradição constitutiva; outra, ao problema da mediação, dos discursos, das racionalidades ou instrumentos simbólicos formadores do sujeito; e uma terceira, à interrogação sobre a construção do real envolvido na experiência subjetiva. No corpo do capítulo que desenvolvemos aqui não há como trazer minúcias e afluências de tal aprofundamento, embora reconheçamos sua pertinência esclarecedora, motivo pelo qual pinçamos alguns parágrafos para juntar à nossa "vagueagem" e assim circular um pouco mais da função do educador. Vejamos como nos ajuda a adentrar na investigação a respeito do assunto:

A questão do sujeito implica na coordenação de uma tripla indagação: o que sou? Como sou? Quem sou? No primeiro caso enfatizo o sujeito como mesmidade, o fato de que sou um ao longo do tempo, em continuidade ininterrupta e permanente. Sou uma conjunção de predicados que me objetiva e nos quais me alieno por comparação. (...) Sou o conjunto de minhas identificações. Sou então a construção aberta de uma obra indefinida? No segundo caso - como sou? - , a resposta me envia à relação que sustento com a palavra que empenho, o cuidado de si, a reunião heterônoma daquilo que me faz como questão: descrever, relatar, prescrever. Sou a intriga formada pela história de minha vida e as peças que não se acomodam nesta narrativa. Aqui não há nenhum tratamento possível da questão sem o reconhecimento de que só apreendo quem sou quando fora de onde estou. "Para haver questão, o ser deve ter dois nomes: vazio e penumbra" 27 . Sou onde não penso, penso onde não sou. Quando sei o que desejo não sei quem sou, quando sei quem sou já não sei mais o que desejo. Sou então efeito de uma constituição que me escapa? Isso leva à terceira pergunta: quem sou? Aqui ponho em questão minha ipseidade ${ }^{28}$, ou seja, aquilo que me faz próprio, essa mistura única entre identidade e diferença. Aqui falo em minha descontinuidade na experiência, na escansão do tempo, na enunciação instantânea e fugaz do sujeito, no seu desaparecimento no ato e nos atos de sua palavra. Sou então ali onde não me encontro, sou apenas ali onde o outro me convoca e onde mal me reconheço na penumbra deste vazio. Sou então efeito de uma formação que me escapa? (Idem, ibidem, p. 21-22.).

Na ideia de construção, afirma, faz-se presente a dimensão da continuidade e homogeneidade do processo da produção de objetos a partir da combinação ou articulação de elementos, opondo-se a tudo que é dado como natural, inato ou espontâneo. "Tal continuidade pode se manifestar, privilegiadamente, por meio da síntese, entre meios e fins, elementos e relações, partes e todo" (Idem, ibidem, p. 34). Um ponto de partida teórico que inside na psicologia construtivista, escreve, considera o sujeito como redutível à consciência, ou ao

\footnotetext{
${ }^{27}$ BADIOU, A. Ser, existência, pensamento: prosa e conceito. In: Pequeno Manual de Inestética. Estação Liberdade, São Paulo, 2002, p. 128.

${ }^{28}$ Segundo Houaiss: o caráter particular, individual, único de um ente, que o distingue de todos os outros; hecceidade. O termo foi recuperado no século XX pelo heideggerianismo.
} 
conjunto das funções psicológicas por ela centralizado e representado como ocorre, por exemplo, a Piaget, quando concebe a consciência primitiva fechada em si mesma e exterior ao outro, numa espécie de autismo, em que o estado inicial da consciência equivaleria a um núcleo íntimo, solipsista - espécie de núcleo "inconstruído" -, de toda construção posterior, numa configuração em que o pensamento caminha do individual para o social ${ }^{29}$. Oposto a este entendimento piagetiano, o construtivismo de Vygotsky propõe o sentido contrário, pois a criança, por natureza egocêntrica, teria a consciência estruturada pela linguagem, já que o uso social da mesma comandaria a formação da intersubjetividade. Em outras palavras, não seria a construção autônoma de conceitos que constrói o real, mas o real-social que constrói os conceitos e a consciência que lhe é necessária. A intersubjetividade seria propiciada, então, através de certa realização simbólica do outro como tal, e o pensamento desenvolverse-ia, vetorizado, do social para o individual.

O conceito de constituição, por sua vez, remete à ideia de descontinuidade. Etimologicamente constituir procede do ato de fundar, instituir, criar. Em oposição à noção de homogeneidade do construtivismo, a noção de constituição tem afinidade com o corte, a ruptura, a heterogeneidade. Pode-se dizer, afirma Dunker, que as teorias da constituição se preocupam com as regras que criam um dado universo de discurso - regras constitutivas de um jogo de linguagem - , enquanto as teorias construtivistas tendem a enfatizar o estudo das regras que regulam um universo de discurso. De qualquer maneira, apontando o que parece uma proximidade, ambas as posições quanto ao estatuto do sujeito, construtivista ou constitutivista, mostram-se compatíveis com a noção de intersubjetividade:

No caso da tese da construção supõe-se uma espécie de autorregulação "espontânea" que torna difícil discernir uma alteridade separadora, crítica e simbólica de uma alteridade alienante, ideológica e imaginária. Desde que o processo seja de fato baseado na construção, seu destino, ou seu telos, estará garantido. Os meios são as garantias para os fins. A autonomia da consciência tende a decorrer da força dos sistemas simbólicos. No caso da tese da constituição, supõe-se uma espécie de heteroregulação. As possibilidades de controle do processo são muito precárias. A autonomia do simbólico é afirmada com anterioridade à da consciência individual. (...) a posição constitutivista enfatizará a heterogeneidade entre o sujeito e as instâncias de mediação (...) envolve, por exemplo, aquilo que não se pode antecipar no ato, mas que, retrospectivamente determina seu sentido. $\mathrm{O}$ sujeito não está no lugar de causa, demiurgo ou construtor, mas no lugar de

\footnotetext{
${ }^{29}$ Esta leitura de Piaget, entretanto, provoca controvérsias. Lajonquière, por exemplo, entende diferente. Ver "Para ler de Piaget a Freud", apresentação escrita em 2010 para a primeira reimpressão do livro De Piaget a Freud: para repensar as aprendizagens. A (psico)pedagogia entre o conhecimento e o saber, após a 15a . Edição, pela Editora Vozes.
} 
efeito, de crise ou lacuna em relação às instâncias de mediação ${ }^{30}$ (Idem, ibidem, p. 51).

O paradigma da constituição sem dúvida recebe impulso da psicanálise quando esta postula, de forma axial, o descentramento e a heterogeneidade entre o sujeito e suas instâncias de mediação - afirma o autor, juntamente com Foucault - , e isto não é um mero detalhe, pois a existência do inconsciente implicará pôr sob suspeita permanente a noção de realidade ou referente. "A essa forma de realidade, imprevisível, imperfeitamente representável e por definição obscena (no sentido de fora de cena, ou fora do lugar prescrito pelo eu), Lacan chamou de real" (Idem, ibidem, p. 49).

A interveniência do inconsciente leva à indagação sobre a natureza da alteridade constitutiva do sujeito, pois se o inconsciente "se representa e se inscreve em mediações heterogêneas ao sujeito e se o sujeito, mesmo assim, é efeito ou suposto a estas mediações, como explicar que o eu seja ao mesmo tempo unidade e dispersão, continuidade e evanescência, interioridade e exterioridade?" (Idem, ibidem, p.53-54).

- O sujeito alucina, fantasia, sidera, viaja no planeta Borromeo entre Real, Simbólico, Imaginário, ... enquanto no meio, o a ... refrata...

Sendo assim, reconhece-se na questão do sujeito a importância da mediação, sim, mas também a indagação sobre o real envolvido na experiência subjetiva, ainda que estas questões não se articulem, formando planos de investigação separados e independentes.

A questão do sujeito implica, quero crer, na retomada do horizonte epistêmico fora da grade naturalista ou positivista. O desejo de uma razão coerente, da argumentação consequente e de mediações eficazes tem se colocado insidiosamente ao lado de uma crítica da razão. Aqui cabe lembrar a importância intersubjetiva da retórica, o poder prescritivo da literatura e a força inelutável da poesia. Não há teoria do sujeito que contemple sua experiência sem dar conta, rigorosamente, desta dupla exigência. Nela o que está em jogo é apenas a retomada da questão da verdade, obscurecida na penumbra do saber e no vazio dos nomes (Idem, ibidem, p. 32).

- Sim, a intertextualidade não toma seu assento ao acaso...

Desta feita, não basta dizer que o sujeito é constituído ou construído pelas relações intersubjetivas:

(...) é preciso mostrar como isso acontece para explicar porquê tal constituição torna dissimétrica as formas de apreensão subjetiva do outro das formas de sobredeterminação do sujeito pelo Outro. Em outras palavras, aquilo que o sujeito apreende intersubjetivamente simplesmente não coincide com a estrutura que o determina e localiza, mas ambos aspectos compõem o campo do que se pode chamar alteridade. Isso pode ser investigado com a noção de

\footnotetext{
${ }^{30}$ FOUCAULT, M. - Nietszche, Freud e Marx. In: Theatrum Philosoficum. São Paulo: Princípio, 1987.
} 
constituição, uma vez que ela traz consigo o reconhecimento de uma disparidade nas relações do sujeito com as instâncias de mediação, seja ela o desejo, o pensamento inconsciente, a sexualidade ou a configuração edípica (Idem, ibidem, p. 54).

E então o autor nos faz lembrar a teorização de Wallon, que serviu a Lacan para que forjasse o Estádio do Espelho. Para Wallon ${ }^{31}$, a subjetividade não deve ser entendida como um sistema individual e fechado, pois se na origem está dada a precariedade e dependência do bebê humano, suas reações devem e são completadas, interpretadas ou compensadas pelo outro, já que o que há nele, de biológico, é a falta e a indeterminação. Assim, mais constitutivista, que construtivista,

Wallon corresponde a uma terceira via, entre Piaget e Vygotsky. Em outras palavras, nem autismo nem egocentrismo, mas indivisão entre aquilo que deriva da situação exterior e o que deriva do próprio sujeito, mistura entre atos, pessoas e seu objeto exterior, confusão entre eu e outro. Este momento precede o período de alternância, ou de transitivismo, onde não é necessário supor consciência de si, mas ação complementar, ou melhor, especular. "O período de alternância acaba contudo por tornar possível ao eu tomar posição em relação ao outro (Idem, ibidem, p. 57).

Aquilo que Piaget entende como uma espécie de autismo na fala inicial da criança, e Vygotsky como um diálogo interno, egocêntrico, Wallon apreende como uma realização do outro enquanto uma posição discursiva e especular. Na fala da criança pequena, eu e outro se misturam linguisticamente, mas não de maneira consciencialista, afirma Dunker. Em certo momento, por volta dos três anos, entra em cena no jogo especular do eu-outro a superação (ou não) da crise dos três anos quando, para afirmar-se, a criança haverá (ou não) de opor-se. Tomada de posição, de corte, quando o eu começa (ou não) a descolar-se do outro, e na fala da criança em lugar da fala de si na terceira pessoa, "- Nenê fez, nenê quer...", começa a articular-se (ou não) como primeira - do singular “ - Eu não quero, não fui eu... “. V Vejamos:

Com a tomada de posição entra em cena a necessidade de partilha, o protesto contra a partilha e aqui se revela o caráter insensato e determinante do desejo "A criança não procura a utilização mas a propriedade por si só, a propriedade de coisas de que espontaneamente não teria qualquer desejo. (...) Trata-se de apropriar daquilo que é reconhecido como pertencente a outrem.”. A situação de pacificação decorre da instalação da lógica do reconhecimento, da qual a tendência do indivíduo a afirmar-se como um todo fechado seria um efeito. "Simples limite ideal cuja realidade psicológica difere sensivelmente". Wallon nos permite ver o indivíduo como um ideal instituinte, a autonomia como uma das suas principais ideias reguladoras, mas não constituintes. Trata-se de uma ilusão regulatória, que a qualquer momento mostrará sua instabilidade. Isso se

\footnotetext{
${ }^{31}$ WALLON, H. - O papel do outro na consciência do eu. In: Psicologia e educação da infância. Lisboa: Estampa (coletânea), 1975.
} 
mostra nos momentos de crise e incerteza caracterizados pela incitação à tomada de posição, momentos onde o sujeito se sente novamente desapossado de sua consciência pelo outro. São momentos onde se acirra a tensão entre autoridade e submissão. Neles reaparece "o íntimo essencial que é outro. Mas esta mesma relação parece ter por intermédio o fantasma do outro, que cada um traz em si. São as variações de intensidade que este fantasma sofre que regulam o nível de nossas relações com o outro (Idem, ibidem, p. 58).

Por conseguinte, conclui Dunker, Wallon defende uma ideia que poderia ser de Freud: a identidade expulsa a si mesma para se conservar: o recalcado, o infantil e o sexual. O sujeito, portanto, não se constrói apenas, também se constitui ao reconhecer em si aquilo que o nega como tal. "A linguagem pode ser uma instância reflexiva ... mas não toda. (...) O falso reconhecimento e o reconhecimento do falso se combinam na problemática da constituição (em ) uma auto-afecção descontínua" (Idem, ibidem, p. 59).

Basta considerar para tanto o si mesmo como um efeito de refração e desvio, imagem alienada, reflexivamente distorcida. O que o sujeito apreende do sistema (linguístico, cultural ou social) jamais se identifica ao próprio sistema simplesmente porque o sistema determina o lugar de onde o sujeito apreende o sistema. Assim fica claro como a noção de constituição é o que melhor se aproxima, em uma versão dialética, da ideia de estrutura. Como tal, a estrutura possui uma anterioridade lógica em relação ao sujeito, não é a sua história apenas, mas as condições que localizam e instalam o sujeito como tal: fundamentalmente a linguagem e o desejo (Idem, ibidem, p. 59).

Então, o autor defende que a teoria da intersubjetividade em Wallon, relida por Lacan, traz uma boa alternativa para os impasses da concepção freudiana de narcisismo, quando permite uma separação entre a dimensão imaginária e simbólica nas mediações constitutivas e construtivas do sujeito.

Imaginário e simbólico menos que realidades autônomas correspondem a sistemas de relações, formas de uso dos signos ou mais precisamente dimensões distintas da alteridade. O que sincroniza a constituição do sujeito com a constituição da realidade é justamente esta costura conhecida como simbólico ${ }^{32}$. (...) No fundo, a perspectiva da constituição implica a análise desta experiência entendida como processo de socialização da instância linguística que diz $\mathrm{Eu}^{33} \mathrm{em}$ associação com o processo de realização (= tornar real) das instâncias simbólicas da alteridade (cultura, sociedade, lei, morte) . Isso se ilustra muito bem na seguinte afirmação de Wallon:

"Para unificar seu eu no espaço, a criança tem que obedecer a uma necessidade dupla. Em primeiro lugar é preciso que admita a existência de imagens que têm apenas uma aparência de realidade; em seguida, deve afirmar a realidade de uma existência que escapa à

\footnotetext{
32 PRADO JR. B. Lacan: biologia e narcisismo (ou costura entre o real e o imaginário). In: PRADO JR. B. (org). Filosofia da Psicanálise. São Paulo: Brasiliense, 1991.

${ }^{33}$ ARANTES, P. Hegel no Espelho do Dr. Lacan, Revista Ide, 22, p. 64-67, 1992.
} 
percepção. (...) de um lado encontra imagens sensíveis mas não reais e, do outro imagens reais mas subtraídas do conhecimento sensível. Para aceitar o fato de sua existência espaço-temporal a criança tem que subordinar progressivamente os dados da experiência imediata à representação pura. (...) através dela forma-se a noção de corpo próprio, que conduz à unidade do eu" ${ }^{34}$ (Idem, ibidem, p. 60-61).

Entretanto, alerta, se temos que a operação de constituição do sujeito passa pelo reconhecimento de seu caráter puramente simbólico, isso não torna possível identificarmos nenhuma positividade como agente desta constituição. É viável pensar a identidade, mas sem essencializá-la: “A personalidade, o caráter, o si mesmo, a identidade podem ser apreendidos apenas como formas de preenchimento desta falta a ser. A imagem que se forma é algo diferente do que a constitui" (Idem, ibidem, p. 62).

A unidade interiorizada individual é vista como um fenômeno precário, instável, de assumpção jubilatória da imagem de si, captada reflexivamente a partir do semelhante. Novamente o que é constitutivo nesta operação é o que a imagem não revela, é o que o representante não representa. Leitura semelhante se encontrará nos desenvolvimentos de Lacan sobre a lógica do tempo ${ }^{35}$, da causalidade ${ }^{36}$ e da alienação ${ }^{37}$. Temos assim um eu concebido como instância de desconhecimento e negação, meio ou instrumento pelo qual o sujeito coloca sua questão Daí o fato de que o eu não seja considerado uma instância sem contradições (Idem, ibidem, p. 63-64).

- Ahhhh... ãããã... Ió, Ió... Não há como negar: Ressoa como música em meus ouvidos...! Por isso os manuais de "como educar tudo em todos e todas" não costumam operar...

Se o estranho volta sempre, à tona, e na transferência com o educador não se mostrará diferente, eis porque se faz necessário tentar tecer os pontos, não em sutura, mas em bordados, da articulação entre sujeito, mediação e real, concordamos. Será como na dialética hegeliana do senhor e do escravo:

(...) perspectiva da dominação e do conflito intersubjetivo que dominará o entendimento da socialização e não a pressuposição de adequação e

\footnotetext{
${ }^{34}$ ROUDINESCO, E. História da Psicanálise na França, Vol . II, p. 86.

${ }^{35}$ LACAN, J. O tempo lógico e a asserção da certeza antecipada (1945). In: Escritos. Rio de Janeiro: Jorge Zahar, ,1998.

${ }^{36}$ LACAN, J. Formulações sobre a causalidade psíquica (1946). O tempo lógico e a asserção da certeza antecipada (1945). In: Escritos. Rio de Janeiro: Jorge Zahar, ,1998.

${ }^{37}$ LACAN, J. O Seminário, livro 11: os conceitos fundamentais da psicanálise. Rio de Janeiro: Jorge Zahar, 1986.
} 
autonomia: “... no movimento que leva o homem a uma consciência cada vez mais adequada de si mesmo, sua liberdade confunde-se com o desenvolvimento de sua escravidão" 38 (Idem, ibidem, p. 65).

Em suma, inferimos, estando o sujeito na posição de educando, haverá como adequar-se e conquistar a tão almejada autonomia como projetam pais e escolas? Claro que sempre haverá aqueles que conseguirão fazê-lo por conta própria, enquanto outros, na contrafeita, seguirão esperneando toda vez que se depare com a castração e a Lei da proibição do incesto, em situações nas quais o diálogo, possivelmente, de pouco adiantará, por termos ali, na situação de conflito entre Cila e Caribde, em tentativa de diálogo, a lógica de dois, em contratempos - di-a-logos - e não em relação de um para o outro, compreesiva e colaborativa, mas muitas vezes coercitiva, alienante e dominadora.

No itinerário aberto por Dunker, resta ainda um conceito citado da Fenomenologia do Espírito, de Hegel, ligado à questão do sujeito, qual seja, a formação (Bildung), esta que designa, genericamente, o trabalho de apropriação da cultura, do cultivo e aperfeiçoamento de si, propriamente não "uma meta a ser atingida, mas um percurso, um caminho, uma experiência a ser realizada" (Idem, ibidem, p. 69). Formação como um momento histórico preciso da trajetória de constituição do espírito, em que a consciência realiza o fato de que a cultura diante de si simultaneamente a aliena, e então, pelo engajamento a um trabalho de cultivo de si, o homem coloca em questão sua própria educação, num trajeto em que a consciência advém a si mesma quando se reconhece nisto que lhe era, até então, estranho, descobrindo-se na cultura.

Para Hegel $^{39}$ nasce aqui uma aspiração da consciência à universalidade, ao senso de comunidade (Gesellshaft) e de coletividade, posto que a cultura é esta espécie de linguagem universal e herança comum. Mas ao se engajar na formação, o sujeito toma para si a tarefa de reconciliar a sua aspiração teórica, efeito do estranhamento, com sua exigência de dominação sensível. Aqui fica claro como no modelo da formação o sujeito engaja-se consentidamente na tarefa de autodomínio pelo domínio das mediações que o alienam aos objetos. É uma luta pela liberdade, não pela vida, como era o caso da luta entre o senhor e o escravo. A formação, neste sentido, não corresponde apenas a um trajeto de crescimento contínuo por acumulação de repertório e domínio técnico, mas a um autodilaceramento, um esforço por tornar seu o que se herdou, para reconhecer-se com formado e formante da cultura e também por se fazer reconhecer através dela. O caráter admiravelmente dialético da noção de formação, sua implantação histórica e sua extensão simbólica, reúnem dentro de si uma totalidade virtualmente complexa, contemplando a ideia de

\footnotetext{
${ }^{38}$ LACAN, J. Formulações sobre a causalidade psíquica. In: Escritos. Rio de Janeiro: Jorge Zahar, 1998, p. 183.

${ }^{39}$ HEGEL, G. W. F. A cultura e o seu reino da efetividade. In: Fenomenologia do Espírito. Petrópolis: Vozes, 2001, Vol II.
} 
agente, processo e produto. O conjunto é, sem dúvida, atraente para uma teoria do sujeito" (Idem, ibidem, p. 70).

Entretanto, lembra Dunker, tal ideal formativo é posto em cheque pela psicanálise, quando é notório que Freud enfatizava os limites da educabilidade e do autodomínio por conta da existência do inconsciente. Por outro lado, se Freud contrapõe a experiência da psicanálise à experiência de formação no sentido hegeliano de prática cultural educativa, o termo formação é utilizado por ele em vários conceitos psicanalíticos que remetem

(...) a formas específicas de conciliação entre defesa e desejo, entre o eu e aquilo que retorna a assediá-lo depois de ser negado, expulso ou repelido. O eu replica assim a estrutura dos objetos que o formaram, como instância de inibição, desconhecimento e alienação. Reencontramos aqui a lógica hegeliana da formação. (...) No fundo, a lógica reflexiva que impregna a noção de formação põe em questão o estatuto mesmo da ideia de mediação. Há mediações imaginárias (narcísicas) e mediações simbólicas (que realizam a alteridade). Como distingui-las se o conceito mesmo de mediação, no contexto da formação, não carrega consigo nenhuma orientação? Ou seja, a mediação em si mesma não adquire valor algum até que ela incorpore, de alguma forma, o desejo (Idem, ibidem, p. 73-74).

Pois bem, se estamos não morto-vivos, pulsando em falta, vivendo o desassossego abstrato, escorregadio e inadaptável do desejo, desnaturados como fomos pelo uso da palavra, pela castração simbólica realizada em nome de um pai, após sermos marcados para todo o sempre pelo desejo do Outro primordial, maneiras e oportunidades de buscar no tesouro de significantes o que aprender e ensinar sempre haverá, não porque temos consciência de que é preciso fazê-lo, mas pelo próprio movimento inercial do sujeito em tentar completar aquilo que é feito da falta, que é furo, impossível de ser totalmente simbolizado, suturado, motivo pelo qual, por isso mesmo, não se apazigua, não descansa, perdurando em insatisfação seja aos dois, aos sete, aos catorze anos e, por que não?, até o último dia de vida. Um bebê, por exemplo, tendo seu brinquedo à mão, pode fazer um escândalo pelo objeto idêntico do bebê ao lado, ou chorar muito para chegar ao peito da mãe, estando com a barriguinha cheia de comida, sem fome, mas querendo mesmo assim um pouco “de mamar"... Ou um moribundo católico, na outra ponta da linhavita, pode bem em seu último dia desejar receber a Extrema-Unção e esperar morrer sem dores, em pecados perdoados, na intenção de erguer-se aos Céus e adentrar finalmente ao Paraíso... por que não?...

A subjetivação, tentamos corroborar, seja pela construção, constituição ou formação, pode ser um ato contínuo, de passos e contrapassos, sensível aos contratempos de um 
pendular arrítmico, oscilante, em giros e deslocamentos no tempo e no espaço, menos próximo de um pêndulo simples - hipotetizamos - do que de um Pêndulo de Foucault, como voltaremos à frente na tentativa de demonstrá-lo. No percurso arriscado de uma vida a ser inventada uma a uma, cujas vicissitudes são indubitavelmente inexoráveis, é do encontro meio desencontrado com os outros - esses complexos subconjuntos labirínticos do Outro que mudanças subjetivas comumente acontecem, sulcando novas trilhas psíquicas com as quais podemos, em conta própria, nos "constitruir".

O tempo para "constitruição" e formação do sujeito, desta feita, seria o tempo cronológico da infância, da adolescência, o tempo da entrada primordial do bebê-mamífero no campo da linguagem, ou o vaivém retroativo do tempo lógico? A contagem, a propósito, há de ser feita a partir de qual referencial?, da concepção da célula-ovo?; da história familiar fasciculada através das gerações que antecederam a chegada do infans ao mundo?; ou quando, no momento exato do parto, da saída do útero à "luz da vida", em semântica, como se a Origem do Mundo fosse mesmo uma espécie de portal por onde, em seu dentro, reinasse a mais profunda escuridão, enquanto fora, a luz!!!, feito fantasma do buraco negro no universo fantasista do humano?... divagações... perambulagens pensamênticas... Quanto à constituição do bebê humano em sujeito, estará instalada por volta do primeiro ano de vida, após a segunda passagem pelo drama edípico, por ventura no final do período adolescente, na passagem ao jovem adulto, ou no avanço à meia-idade?

\section{- Por favor, tais questionamentos interessam aos educadores?}

Desde Freud, estudos psicanalíticos assinalam que, ao nascer, mesmo com as condições fisiológicas do bebê a contento, o aparelho mental humano não se mostra pronto para funcionar como um aparelho de linguagem. A estruturação psíquica subjetiva não nasce pronta, nem é uma questão de desenvolvimento cerebral, mas é algo que tem de ser elaborado. Felizmente, para a grande maioria de pequenos e de pequenas que chega ao mundo, as chances disso acontecer não parecem raras. Mas acontecem.

As relações do bebê com outros sujeitos, ou seja, com humanos mais crescidos cujos aparelhos de linguagem já se encontram em funcionamento há algum tempo, lançar-lhe-ão no circuito do Outro $^{40}$. De princípio, o infans será falado pelos significantes que o Outro

\footnotetext{
${ }^{40}$ Outro: Termo com o qual Lacan designa o sistema de elementos significantes ao qual o sujeito, com alguma sorte, será submetido desde o início de sua jornada. "Essa noção de "grande Outro" é concebida como um espaço aberto de significantes que o sujeito encontra desde seu ingresso no mundo; trata-se de uma realidade discursiva de que Lacan fala no Seminário 20; o conjunto dos termos que constituem esse espaço remete sempre
} 
primordial escolherá (inconscientemente) ao ente pequeno, começando por esculpí-lo e metabolizá-lo (ou não) - através do fino fio das palavras proferidas sobre o recém-chegado organismo biológico de carnes, cabelos e unhas - de forma a modelar um corpo subjetivo singularizado. Uma das atribuições da função materna, sabe-se, é justamente falar para e sobre esse pequeno organismo que se mexe, olha, escuta, chora, mama, urina, defeca e dorme. A mãe - ou quem ocupa a função de Outro primordial para o bebê no encarne do Desejo da mãe - será a primeira a depositar significantes na conta do candidato a sujeito, enunciando pela criança enquanto esta não for capaz de fazê-lo. Todavia, felizmente, com empenho do pequeno ser e dos ventos que soprem a favor, o bebendito poderá alçar à fala e quiçá, chegar à ex-istência, como escrevemos entre recortes de Lacan e Guimarães Rosa ${ }^{41}$, no final da monografia anterior. O tempo que levará esse percurso, bem se sabe, é variável, podendo nem acontecer, como mostram as crianças estudadas pela Psicanálise, devastadas pela boca do crocodilo do Desejo da mãe em excesso, ou pela foraclusão do Nome do pai.

Todavia, mesmo que o sujeito escape dos mares de Cila e Caribde - sem dúvida já uma vitória - não significará muita coisa, restando ainda ao herói um bocado a ser feito. Tal como acontece a tantos que aprendem a ler, a contar, sem contudo ultrapassar os limites do analfabetismo funcional, tantos outros aprenderão a falar e mais ainda a contar, abstendo-se da aventura de engajar-se na (im)própria enunciação, preferindo manter-se atado à segurança pré-tensa dos enunciados comumente aceitos, pré-validados pelas tecno-ciências ou normatizados pela moral, evitando a todo custo "ideais que só se sustentam no desconhecimento do desejo de se estar no mundo para fazer nele uma diferença significativa a partir do que se fizer de si" ${ }^{, 42}$.

Qual é o tempo, portanto, do assujeitar-se e, paradoxalmente, advir a um ex-istir? Pergunta difícil de responder, porque a resposta admite múltiplas alternativas, inclusive “nunca”. A psicanálise ensina, lembra Kupfer ${ }^{43}$, que um sujeito pode estar fora da lei, mas não da Lei, porque ainda que possa transgredir as leis dos homens e se tornar um homem vil,

a outros e eles participam da dimensão simbólica margeada pela do imaginário. A instância imaginária do eu se forja em função do que faz falta no Outro" (KAUFMANN, 1996, p. 385).

${ }^{41}$ Em CAMARGO, 2006, cap. IV, p. 126-130, o leitor encontrará O Espelho, de Guimarães Rosa, estilhaçado em recortes, mas ainda profundamente belo.

${ }^{42}$ RUFFINO, R. Sem título. Disponível em: :http://www.orkut.com.br/Main\#CommMsgs?cmm=13036893\&tid=2498385201241317256 . Acesso em $10 / 10 / 2010$

${ }^{43}$ Informação pessoal durante a disciplina Limites e Alcances de uma Integração, IPUSP, em 2007. 
não será sequer homem caso não se submeta à Lei maior que nos faz diferentes dos animais ao regular as trocas sexuais. Nenhum animal, que se saiba, acata esse tipo de interdição, pois animal algum habita o campo da palavra, do significante e, consequentemente, do inconsciente, que é estrutural ${ }^{44}$, motivo pelo qual, possivelmente, tampouco lhes ocorram tentativas suicidas, nem mesmo entre aqueles histericamente domesticados...

Em Radiofonia, jogando com os verbos falloir (ser necessário/preciso, convir, importar, mas também faltar) e faillir (falir, falhar, faltar, enganar-se), Lacan (1970, p. 425) afirma: “... ao ente, precisa tempo para se fazer a ser (se faire à l'être, no original). Esse "precisa tempo", é o ser que o solicita ao inconsciente, para retornar a ele todas as vezes que lhe for preciso. Sim, for preciso tempo."

A questão do tempo foi levantada por Freud já em 1895, no Projeto para uma psicologia científica, ao dar-se conta de que o caminho percorrido por um estímulo desde a percepção até sua inscrição e evocação se dava, muitas vezes, no eixo da sincronia $a$ posteriori, ou seja, quando a ocorrência de um acontecimento só gerava efeitos de significação a partir de outro acontecimento posterior, num movimento retroativo, cujo funcionamento se mostrava para além da linearidade evolutiva e diacrônica, numa lógica “intemporal” em relação à sucessão de eventos, o que o levou a afirmar que o inconsciente desconhece o tempo, já que opera sobre ele de uma forma não linear, nem cronológica. No referido texto, o aparelho psíquico é definido como um aparelho de memória, no qual os processos psíquicos são relacionados a uma "inscrição psíquica", feito "traços mnêmicos". Junto a essa noção de "traço", aparecem pela primeira vez outras que lhe são correlatas: "inscrição", "trilhamento" e "repetição". No entanto, explicita Sônia Borges em pesquisa sobre o processo de alfabetização de crianças da Educação Infantil, a noção de "traço mnêmico" não designa elementos relativos à memória na sua relação com a consciência - tal qual a memória para a psicologia - mas como marca, ou seja, uma intensidade pela qual a impressão mantém seus efeitos:

\footnotetext{
44 “O inconsciente lacaniano não é uma caixa de Pandora de onde sairiam pulsões não-socializadas e conteúdos recalcados. Todos os desejos e pensamentos latentes podem ser reapropriados pela consciência e, por isso, são pré-conscientes. O que Lacan procura é algo que apareça como limite irredutível ao pensamento consciente: Ele o encontrará em duas vertentes. A primeira está na negatividade da teoria das pulsões. Mas a mais famosa ficou cristalizada na fórmula "O inconsciente é estruturado como uma linguagem". Não se trata de dizer que há uma espécie de linguagem privada inconsciente, como se existisse uma estação de rádio clandestina interferindo na estação de rádio pública. De uma certa forma, o inconsciente é a linguagem, ou seja ele é o conjunto de regras estruturais da linguagem que moldam a forma do pensamento consciente. Saímos assim de um registro "arqueológico", no qual o inconsciente é o texto escondido sob o texto da consciência, para transformá-lo na estrutura formal do pensamento (SAFATLE, Vladimir. In: Glossário Lacanês. São Paulo: Folha Mais!, 2001. Disponível em: http://www.oocities.com/vladimirsafatle/vladi006.htm . Acesso em 26/01/2011).
} 
O "traço" é um "rastro" de uma impressão, ou é uma "imprensão", como diz Derrida. Fruto da percepção, (...) não é, contudo, mera resposta aos estímulos da empiria. A "imprensão", assim como a percepção, sendo da ordem da representação, é reconstruída na constituição do psiquismo. A memória de que fala Freud não se confunde, portanto, com a lembrança ou a reminiscência. Afastando-se essencialmente da memória psicológica, (...) a memória freudiana é fundadora, é o próprio psiquismo. Não se trata, então, de memória consciente, mas da capacidade do tecido nervoso de ser alterado de forma permanente, contrariamente à mesma matéria que permitisse a passagem da energia [do estímulo] e retornasse ao seu estado anterior (BORGES, 2006, p. 107, acréscimo nosso).

Borges faz lembrar que, em Freud, a noção de percepção como impressão sensível é abandonada, pois à percepção é conferido o estatuto de representação que, no discurso da psicanálise, remete a processos sob o registro do inconsciente. Em Para uma concepção das afasias (1891), Freud rompe de uma vez com a Filosofia clássica, mas também a Psicologia, ao abordar a questão das representações, provocando um deslocamento de sentido:

(...) esse movimento é anunciado por suas considerações sobre a "representação". [Freud] Não a vê como imagem ou conceito das coisas do mundo, ou seja, como "presença" no substrato mental, mas como um fenômeno psíquico complexo que, devido à própria natureza de sua constituição, é um "nó", uma "trama", desde o início constituída por uma heterogeneidade de representações (Idem, ibidem, p. 106, acréscimo nosso).

Assim sendo, conclui Borges, se as representações são elementos associativos, combinatórios, que resultam não de uma relação entre o sujeito e a coisa, mas de uma relação entre representações, fica implícito que nenhum ato de percepção pode-se fazer independentemente da linguagem, assim como a constituição de representações não pressupõe faculdades mentais anteriores a ela. De fato, como o infans não é capaz ainda de representar em palavras aquilo que sente como frio, fome, medo, prazer, alegria, e tantos outros, é preciso que o Outro primordial fale por ela e para ela, naquele típico diálogo louco entre mãe e bebê, em que a mãe fala pela criança para, em seguida, ela mesma responder aquilo que imagina estar se passando com o filho, como num di-a-logo louco...

- "Ué? Ufoioquê, mamófilinha? Bebecoli, xoranão,... totunfómi quémamá? Dói-dó-dóii, ué seráquequié?... numnumsei, só sei ficaqui xoranxorando, chamando ucezica, num teeeempão e tucê nem qui numvem - quitucê feia, molvada ... Ah, cuiuiuzinha, bebecululu da mamica, tão lindolina, tão cururu, xora não, tucezinha Bebequinha do meu coração, mãica vaipegá, dádimamá, trocáxixicocô, tuficá beeeem limpinha, bemmmm gostosa...hummmmmmm..pronto, venqui: .... - Chlep!

Mmmmmamamamamamamamamamamam ... zzzzz ...

Mamamamamamamamamama ... zzzzzzzzzzzzzzzzzz ...

Mamamamamamamama ... zzzzzzzzzzzzzzzzzzzzzzzz ... 
Mamama ... zzzzzzzzzzzzzzzzzzzzzzzzzzzzzzzzzzzzzzzz ...

Mama ... zzzzzzzzzzzzzzzzzzzzzzzzzzzzzzzzzzzzzzzzzzz ...

- Ito, cuiú,... mamutucê...dórmibeimzzzzzzzzz ...

"O tempo é sempre o do Outro que me espera, que me apressa para responder a sua demanda." (Bernard Nominé, in Em prelúdio... texto escrito para Os tempos do sujeito do inconsciente, evento do Fórum Lacaniano, 2007).

Enquanto educadora, envolta nos estudos da psicanálise, parece-me que a constituição do sujeito, sua formação ou construção, embora tenha um tempo para começar a acontecer, é um percurso a ser percorrido por uma vida toda, seguindo aberto a avanços e retrocessos conforme as vicissitudes dos acontecimentos, quando nem tudo o que ocorre é escolhido ou consentido, desejável. Queremos afirmar que a função do educador está posta exatamente aí, tanto para ajudar a viabilizar ex-istências, quanto no embate contra a barbárie, na tentativa de educar o homem de forma que este não responda ao lobodolobodolobo do homem.

Quando um educador sustenta a palavra em Nome-(im)próprio ${ }^{45}$ - e não em nome de uma tecnociência acéfala de matéria-prima morta - , em última instância, o faz em nome da castração e do desejo que o anima. Quando isso acontece, o agente da função do educador acaba oferecendo meios para que os educandos garimpem, nos escombros e tesouros do Outro, singulares trilhares para si, ainda que para alguns, como diz Lajonquière em tom de brincadeira - mas nem tanto - , o tempo de uma vida não bastará.

Sigamos no circular, em torno da função do educador.

\footnotetext{
${ }^{45}$ Sobre a cunhagem deste termo, no último capítulo, iremos explicá-la.
} 


\section{Circo}

Nunca achei que fosse uma transgressão furar circo. Ainda porque a gente não sabiava o que era aquela palavra. Achávamos que transgressão imitava traquinagem. Mas não tinha essa imitagem. Transgressão era uma proibição seguida de cadeia. Algum tempo depois li uma crônica do grande Rubem Braga na qual ele contava que ficara indignado com uma placa no jardim do seu bairro onde estava escrito: É proibido pisar na grama. Braga viu-se castrado em sua liberdade e pisou na grama e pisou na grama. Fecha parênteses do Rubem. Mas a gente furava circo assim mesmo. Na ignorância. Partia que éramos em cinco. Quatro guris de seis anos e o Clóvis, nosso comandante, com doze anos. Clóvis seria o professor de as coisas que a gente não sabiava. Partiu que naquele dia furamos a lona do circo bem no camarim dos artistas. Ficamos arregalados de alma e olho. E o Clóvis se deliciava de olhar as trapezistas. Elas ficavam nuas e se trocavam. As trapezistas tinham uma aranha escura acima da virilha. O Clóvis logo nos ensinou sobre as aranhas. Que elas tinha um corte no meio e podiam ser negras ou ruivas. Contou-nos o Clóvis que ele tomava banho com a tia dele todos os dias. E que a aranha dela era enorme que as outras. Depois ele perguntou-nos se sabíamos por que as mulheres não mandam urina longe, a distância? A gente não sabia. E o professor nos ensinou. É porque elas não tem cano. Era só uma questão de cano! A gente aprendeu.

Manoel de Barros

Memórias Inventadas: A Terceira Infância 


\section{O assento do discurso pedagógico}

No início de 2008, funcionários da educação do Estado de São Paulo entraram em greve reivindicando reposição salarial, incorporação de todas as gratificações extensivas aos aposentados, plano de carreira justo e a revogação das leis 1.093 (dispõe sobre a contratação de servidores em caráter temporário), 1.097 (a respeito ao Programa de Valorização pelo Mérito) e 1.041 (define como critério de mérito para bônus salarial o número máximo de uma falta por mês e seis por ano, independente do quadro clínico apresentado). Imediatamente, a Revista Veja $^{46}$ fez publicar o artigo de Gustavo Ioschpe ${ }^{47}$ intitulado "Educação de quem? Educação para quem?", no qual argumentava que a melhoria da qualidade da educação não passa pelas questões levantadas por esta "cantilena corporativa":

É uma cantilena que tem lógica, claro. Faz sentido imaginar que professores e funcionários de ensino mais bem pagos serão mais motivados e, portanto, darão aulas melhores, ou que conseguirão dedicar mais atenção a cada aluno em salas menores, ou que a presença de equipamentos multimídia ou de uma quadra poliesportiva tenha efeitos positivos - assim como é bastante lógico imaginar que o Sol orbita ao redor da Terra, que o planeta é quadrado, que uma garrafa cheia de água chegará antes ao solo do que uma garrafa vazia ou que a melhor forma de combater uma doença que se espalha pela corrente sanguínea é retirando sangue do corpo por meio de sanguessugas. Muito do que é lógico é falso, e muito do que é verdadeiro é contra-intuitivo. A única maneira de estabelecer a verdade é testando, empiricamente. (...) O problema não é que a corporação dos profissionais do ensino puxe a brasa para a sua sardinha; o problema é que eles tenham conseguido fazer com que o país aceite como sendo um programa para o bem comum aquilo que é, na verdade, a defesa dos interesses da sua categoria profissional (grifo nosso).

No terreno preparado pelo economista, menos de um mês depois, Maria Helena Guimarães de Castro, enquanto secretária da Educação do Estado de São Paulo, acrescenta às reivindicações dos professores outro atributo: "ladainha sindicalista". Em entrevista exclusiva à revista, no rechaço da palavra dos funcionários da educação paulista para defender o sistema de premiação em detrimento de um plano de carreira mais justo, além da reposição salarial, aproveitou para questionar a qualidade de formação dos cursos de pedagogia, sem deixar de pontuar que a solução para um ensino melhor estaria atrelada a medidas técnicas, precisamente, no investimento em: 1) produção de material didático "condizente com as

\footnotetext{
${ }^{46} 2043$ - ano $41-$ n. 2,16 de janeiro de 2008 , p.32 e 33.

${ }^{47}$ Economista brasileiro com formação nos EUA, consultor do Banco Mundial para o MEC.
} 
evidências científicas das práticas pedagógicas que de fato funcionam"; 2) cursos para melhorar a formação dos professores; e 3) programas de valorização dos bons educadores.

Maria Helena - (...) Fiz uma pesquisa sobre o assunto na qual professores entrevistados em diferentes estados brasileiros repetiam a mesmíssima ladainha: "As notas dos alunos são ruins porque a escola pública é carente de recursos e os professores ganham mal". Não acho que seja razoável atribuir tudo a fatores externos. Segundo essa mentalidade atrasada e comodista, a culpa pelo péssimo desempenho geral é invariavelmente do estado brasileiro, nunca dos próprios professores, muitos dos quais incapacitados para dar uma boa aula. A falta de professores preparados para desempenhar a função é, afinal, um mal crônico do sistema educacional brasileiro. Sem desatar esse nó, não dá para pensar em bom ensino.

Veja - Qual seria o melhor caminho para elevar o nivel dos professores?

Maria Helena - Num mundo ideal, eu fecharia todas as faculdades de pedagogia do país, até mesmo as mais conceituadas, como a da USP e a da Unicamp, e recomeçaria tudo do zero. Isso porque se consagrou no Brasil um tipo de curso de pedagogia voltado para assuntos exclusivamente teóricos, sem nenhuma conexão com as escolas públicas e suas reais demandas. Esse é um modelo equivocado. No dia-a-dia, os alunos de pedagogia se perdem em longas discussões sobre as grandes questões do universo e os maiores pensadores da humanidade, mas ignoram o básico sobre didática. As faculdades de educação estão muito preocupadas com um discurso ideológico sobre as múltiplas funções transformadoras do ensino. Elas deixam em segundo plano evidências científicas sobre as práticas pedagógicas que de fato funcionam no Brasil e no mundo. Com isso, também prestam o desserviço de divulgar e perpetuar antigos mitos. Ao retirar o foco das questões centrais, esses mitos só atrapalham.

Veja - A senhora pode dar alguns exemplos desses mitos?

Maria Helena - Um dos mais populares é aquele segundo o qual o aumento no salário dos professores leva sempre à melhoria do ensino. As pesquisas mostram que, quando o dinheiro vem dissociado de uma política de reconhecimento do mérito, ele surte pouco ou nenhum efeito. Um segundo mito bastante divulgado diz respeito ao tamanho das classes. Os educadores afirmam por aí ser impossível oferecer uma boa aula diante de classes cheias, mas os estudos sobre o assunto indicam que, tirando as séries iniciais, esse é um fator de pouca relevância. Escolas de diferentes países decidiram inclusive aumentar o número de alunos em sala de aula para resolver outra questão esta, sim, de grande efeito positivo. Eles estão esticando as horas de permanência dos estudantes nas escolas e, para arcar com os custos da medida, precisam fazer caber mais gente numa mesma sala.

Assim, o estilo de ambos, economista e secretária, nos impeliu a sair em busca do lugar em que se assenta o discurso neoliberal que tanto contribui para a contemporânea desqualificação do educador. Por entender o artigo e a entrevista politicamente tendenciosos, porém contundentes na formação da opinião pública, decidimos utilizá-los para pensarmos questões que permitissem algum alinhavo entre o discurso pedagógico, a contemporaneidade 
e a psicanálise. Foi assim que adentramos à teoria dos discursos em Lacan para, num primeiro momento, acabar reconhecendo no estilo dos tecnocratas o funcionamento do discurso do capitalista e, num momento segundo, para darmos continuidade à nossa procura a respeito das condições para que a prática escolar possa acontecer sem estar atrelada ao discurso metodológico de ensino, nem a "didáticas magnas", tidas como imprescindíveis ${ }^{48}$.

\subsection{O ortodoxo e obsessivo}

No trabalho anterior, de passagem havíamos adjetivado a pedagogia ortodoxa como "obsessiva" sem nos darmos conta que seria possível e até desejável aprofundar a intuição, o que fez abrir e permanecer retornando um novo incômodo: havíamos incorrido em exagero? Então buscamos conhecer um pouco mais sobre essa entidade, ou melhor, sobre as especificidades de funcionamento dessa estrutura psíquica, a fim de verificar a pertinência de tal representação. Devido a entendermos o fazer educativo das diretrizes metodológicas de ensino como uma forma discursiva ${ }^{49}$, tal qual ocorre no império do discurso psicopedagógico, não nos causaria espanto que ambas discursividades, da ortodoxia e da obsessão, no fundo a mesma, acabassem dando provas da lógica da referida neurose. No campo escolar, tal matriz responderia por transpor ao fazer pedagógico o funcionamento de um discurso assentado em enunciados legitimados pela tecnociência, trabalhando pela supressão da enunciação do sujeito em prol disto que nos parece um modo duro de praticar o ensino, produzindo espécie de maquinar pedagógico semelhante à prática do beato ortodoxo que decora e repete textos sagrados. A título de curiosidade, faço saber, que o termo ortodoxo usado por nós para adjetivar a pedagogia costumeira não precipitou em pensamentos em outra ocasião senão durante uma reportagem televisiva sobre os costumes da Igreja Católica Apostólica Ortodoxa.

\footnotetext{
${ }^{48} \mathrm{O}$ resultado deste estudo foi intitulado " 'Ladainha de professor', qual o assento desse discurso?” e serviu para avaliação final da disciplina de pós-graduação "A Psicanálise, o Discurso Pedagógico e a Contemporaneidade”, ministrada por Rinaldo Voltolini . Disponível em :

:http://www.proceedings.scielo.br/scielo.php?script=sci arttext\&pid=MSC0000000032008000100014\&lng=es\&

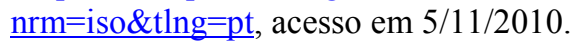

${ }^{49}$ Discurso no sentido de "raciocínio que se realiza pela sequência e que vai de uma formulação conceitual a outra, segundo um encadeamento lógico e ordenado" (Cf. Dicionário Houaiss), mas também como "(...) determinado grupo de fala decantado e sedimentado pela história: é a realização individual de todo o social que há na língua" (PEREIRA, 2008, p. 127).
} 
- Sim, a pedagogia costumeira parece uma religião, cuja bíblia é re-escrita em forma de preceitos didático-metodológicos ${ }^{50}$.

Não por acaso, a ortodoxia e a obsessão se encaixavam em nossas suposições, o que só viemos a saber quando encontramos em Freud a comparação entre o exercício religioso e o ritual obsessivo, assimilando este último a "uma religião privada". Mas de que maneira isso se daria no campo pedagógico? Vejamos como funciona a estrutura dessa neurose.

Durante uma de suas conferências realizadas na Escola Lacaniana de Psicanálise do Rio de Janeiro sobre a neurose obsessiva, em 2001, Charles Melman, a certa altura, pergunta à plateia que verdade é essa de que a psicanálise tanto fala ${ }^{51}$. É a que está do lado do sujeitoresponde -, aquela à procura do conceito ou do sentido que seria adequado para responder a uma ausência, a um furo, à falha radical que constitui sua existência. Em seguida, passa a contar sobre a ambição de Lacan, no final de sua vida, a respeito de tentar dar uma ordem, uma estrutura, uma organização científica à Psicanálise:

(...) ele disse algo que me perturbou muito; ele disse em um Seminário: "tudo o que fiz, o fiz com uma pequena parte do meu inconsciente". Ele nunca disse: eu tenho a mestria, eu sabia tudo o que estava para fazer. Ele dizia: "eu fiz tudo isso sendo inconsciente e sem saber o que estava fazendo". Mas, é claro que fazia para tentar responder ao que foi para ele a falha, o sintoma - o que foi para ele o mais importante, seu próprio sintoma. E o que foi para ele seu sintoma foi o fracasso da relação sexual. Ele não dizia que seu sintoma seria o mesmo para todos; e quando escutava seus alunos elaborarem seus trabalhos, tentava compreendê-los como sendo algo que vinha do sintoma do aluno. Ele fez uma conferência numa universidade americana, já velho, em 1975, em que disse: "vou lhes dizer porque eu vim para a psicanálise. Por qual sintoma eu vim para a psicanálise. Eu vim para a psicanálise porque não há relação sexual. E vocês, por que vieram para a psicanálise?" Sem resposta... Mas, com isso, mostrava que uma elaboração teórica, quer dizer, os enunciados, encontram sua verdade nisto que é a dor de existir do sujeito. $E$ é aí, na dor de existir do sujeito, que se encontra a verdade dos enunciados. E quando o obsessivo quer suprimir esta existência do sujeito e substituir as enunciações unicamente por enunciados, ele duvida de tudo, não está mais seguro de nada, não tem mais certeza de nada (MELMAN, 2004, p. 47-48, negrito nosso).

O obsessivo é aquele que pretende todo saber, que se apraz com os comandos e cálculos, de preferência exatos pois, se pudesse funcionaria como uma máquina regulada e

\footnotetext{
${ }^{50} \mathrm{Na}$ graduação em Pedagogia, não é raro que o aluno seja levado a reiterar em trabalhos e provas de diferentes disciplinas isto que toma ares de jargões: "O professor deve respeitar o nível cognitivo do aluno", "O professor deve diagnosticar os conhecimentos prévios dos alunos", "O professor deve propor atividades propostas compatíveis com a zona proximal de desenvolvimento da criança”, entre outros. Aconteceu conosco.

51 Verdade: "Dimensão essencial da experiência psicanalítica, à medida que esta não tem, no sentido que lhe dá Lacan, outro fundamento senão a fala." In: CHEMAMA ; VANDERMERSCH, 2007, p. 385. Sobre "eu, a verdade, falo", ler “A coisa freudiana”. In: Escritos, Lacan, 1998.
} 
precisa. Diferente da histérica que é dada a espetáculos encenados através do próprio corpo, esse outro neurótico é aquele que se esforça por não aparecer, por ser discreto, falar pouco, de preferência baixo, evitando singularidades, estratégia que formata para manter-se anônimo, escondido, misterioso, feito ali não ocorresse sujeito, especialmente o que falha durante a enunciação. Enquanto histéricas gozam a céu aberto, estampando seu destempero, esse outro personagem goza em reserva, na solidão. Agrada-se de levar na aparência o equilíbrio, a sensatez, o grande senso moral. Pudico e escrupuloso, em geral, é cultivador da religião e da racionalidade, motivo pelo qual, não raro, chega a ser bastante culto. A certeza de que esteja tudo nos seus conformes, tranquiliza-o, acenando-lhe a possibilidade ilusória do domínio de si e das coisas do mundo que, no caso específico em questão, equivaleria ao domínio sobre o processo de ensino-aprendizagem. O pedagogo obsessivo é o que acredita nos rituais metodológicos como lastro de sua ação. Seu bem ensinar deve estar para um exato aprender. Se algo sai a contratempo, não há de ter sido por seu descuido, ou responsabilidade, não!. O déficit deve ser acrescentado na conta do aluno, que não faz a contento o que é da sua parte.

Entretanto, assim como o obsessivo não consegue se livrar da delícia e tortura que são suas fantasias obscenas, violentas, injuriosas, escatológicas e até mesmo criminosas a penetrar-lhe a vida psíquica - de preferência em situações que exigem respeito, devoção, submissão - , também o pedagogo ortodoxo não consegue se livrar do que fracassa no ensinar e no aprender, ainda que se acerque dos últimos e mais científicos materiais e prescrições didático-psicopedagógicos. Obsessivo e ortodoxo, cada a qual a sua maneira, esforçam-se pelo controle interno e externo na evitação do inesperado. Contudo, num átimo de segundo, postados estão a lidar com o real, esgoto mal cheiroso de pruridos e agressividade, que civilidade e religiosidade alguma são capazes de encobrir. Perfeccionistas, senhores dos mínimos detalhes e ordens, houvesse meios suturariam aquela ferida primordial, a marca da castração que puderam, nos primórdios de uma infância, saber da mãe e do consequente ódio que enviou ao pai. - Pudesse matava-o... Não! Jamais, nunca pensei uma coisa dessas!... Castração que, em última instância, serviu de corte por onde entreabriu a fenda para escapar, em parte, da célula narcísica, confrontando- se com o não de um pai, com o falo, com o significante da falta; o mesmo corte, primeiro, que denegam e forcluem, forcluindo o real - categoria que se opõe a todo fechamento - , foraclusão ${ }^{52}$ que

\footnotetext{
${ }^{52}$ Foraclusão: “Conceito forjado por Lacan para designar um mecanismo específico da psicose, através do qual se produz a rejeição de um significante fundamental para fora do universo simbólico do sujeito. Quando essa rejeição se produz, o significante é foracluído. Não é integrado no inconsciente, como no recalque, e retorna sob
} 
não só explica o horror a tudo que lhe escapa, como torna inteligível o mais-de-gozar ${ }^{53}$ que desfrutam pelas ideias totalitarizantes.

Assentar o fazer pedagógico em prescrições assertivas de ensino, a exemplo, configura aos professores um discurso totalitarizante. Entretanto, como nem tudo é ainda ensino à distância, nem os procedimentos todos informatizados, o professor presencial ainda se lança à fala com seus alunos e o inevitável craquelamento da formatação pedagógica ortodoxa acontece.

Mas como e por que desconfiar de personagem tão austero, que se esforça tanto para não pecar, evitando ferir ou traumatizar o outro/a criança/o aluno, sacrificando o desejo que lhe é próprio, em nome do bem estar alheio?

(...) Tem uma alma de funcionário público, mas também na família; ele é o funcionário do pai. Ele faz tudo o que é preciso, ele trabalha, se sacrifica para o bem-estar de sua família e sacrifica seu próprio prazer em função dos seus. (...) Então, talvez vocês reconheçam na minha descrição que o obsessivo é o melhor entre nós. Em todo caso, é o que quer ser o melhor. E então, como podemos ousar fazer uma imagem patológica daquele que quer ser o melhor entre nós? (...) Primeiro porque, em um certo número de casos, eles sofrem terrivelmente. E, quanto mais tentam ser melhores, mais eles sofrem. Quanto mais tentam ser morais, tanto mais são parasitados por pensamentos obscenos e escondem sempre sua doença. A histérica mostra doenças que não existem; o obsessivo tem um sofrimento verdadeiro que ele tenta sempre esconder, dissimular. Por quê? Podemos dar logo uma primeira resposta. Porque isto seria mostrar que há uma falha nesta espécie de felicidade perfeita que ele quer mostrar. E nós analistas sabemos que se trata de uma figura da patologia porque se trata de um sujeito que trata de se defender contra isso que os psicanalistas chamam de castração. E que a defesa contra aquilo que chamamos castração tem sempre consequências patológicas (Idem, ibidem, p. 14-5).

Eis uma estrutura que faz habitar no sujeito a culpa pelo desejo de morte do outro sem, contudo, reconhecê-la. Seriam os "santos", não fosse o inevitável e mal-dito retorno do recalcado, impondo-lhes o encontro com o que causa horror, a produção inconsciente, o real. Pero em que medida tudo isso nos interessa, uma vez que o foco é a função do educador?

Quando o endereçamento pedagógico se efetiva discursivamente numa matriz semelhante, não em nome próprio, mas em nome do que prega o discurso da tecnociência

forma alucinatória no real do sujeito. No Brasil também se usam "forclusão", "repúdio", "rejeição" e "preclusão" " (ROUDINESCO ; PLON, 1998, p. 245). Segundo Lacan, "[a forclusão do Nome-do-Pai é a ] falha que dá à psicose sua condição essencial, com a estrutura que a separa da neurose" (Pascale Dégrange. In: CHEMAMA ; VANDERMERSCH, 2007, p. 156, acréscimo nosso).

${ }^{53}$ À frente definiremos esse conceito. 
psicopedagógica - como veremos à frente na teoria dos discursos em Lacan - , não é de espantar que os efeitos distem dos alvos pré-estabelecidos e a ortopedia do reforço escolar, ou da medicalização psiquiátrica sejam chamadas em cena, forçando mais uma vez o aluno à aprendizagem que não tatuou, porque não fez diferença. Muito do fracasso no aprender inferimos a partir da clínica do aprender - talvez não seja mais do que reflexo e forma de defesa do alunado posicionado em lugar de objeto para validação teórica, como bem alertou Maud Mannoni, na recusa de algo que não foi fabricado para ser endereçado exatamente a ele, educando, mas ao próprio educador na tentativa de evitar a angústia da castração frente ao impossível da profissão, numa lógica semelhante à que se encontra em "Carta Roubada" 54 , de Edgar Allan Poe. A propósito, o trecho de Educação Impossível que versa sobre isso é importante que ser lembrado:

A educação [perversa] está subordinada à imagem de um ideal estabelecido logo de entrada pelo pedagogo [ortodoxo] e que, simultaneamente, proíbe toda e qualquer contestação desse ideal, ou seja, do desejo que serve de suporte à sua opção pedagógica; pede à criança que venha ilustrar o fundamento de uma doutrina. Tal opção tem suas raízes no imaginário (do educador) e participa de todas as divagações referentes a um mundo melhor (...). Uma pesquisa pedagógica que estabelece desde o início o ideal a atingir só pode desconhecer o que diz respeito à verdade do desejo (da criança e do adulto). Expulsa do sistema pedagógico, essa verdade retorna sob a forma de sintoma e se exprimirá na delinquência, na loucura e nas diversas formas de inadaptação. (...) Efetuar uma verdadeira reflexão sobre a educação implica o esforço de constituir uma doutrina científica e de se livrar da falta de pontos de referência que caracteriza o imaginário. E é aí que a psicanálise pode entrar com sua contribuição; ao superar a dualidade natureza-sociedade, ela sublinha a relação de ambas com a linguagem, relação apreendida no estudo do nascimento do desejo nesse indivíduo humano, o qual, antes mesmo de estar apto a usar a palavra, fez a experiência de pertencer ao mundo da linguagem e apercebeu-se de que esta constitui um de seus polos; e por conseguinte, que o Outro podelhe responder sim ou não. Assim, a doutrina psicanalítica tem por efeito marcar essa entrada na cadeia significantes que converte a criança em sujeito; ao destacar-se aquilo que a ação analítica foi chamada a perturbar na relação entre o sujeito e o significante, indica-se simultaneamente o que separa essa prática de toda ação social, religiosa, pedagógica ou política (MANNONI, 1957, p. 44-45, acréscimos nossos).

- Isto que me enfiam pela boca, não posso mais digerir. Fechando-me, encontro meios de dizer "não", seja com a anorexia escolar, seja com um tipo de bulimia intelectual pela qual engulo conteúdos e depois vomito toda forma de idiotias em respostas onde não se encontram os sentidos. Ao menos assim dificulto a sorvedura de minha alma, embora não evite o gozo que desfrutam com os diagnósticos encomendados sobre mim.

\footnotetext{
54 “A Carta Roubada”. In: LACAN, J. Escritos, 1998.
} 
A fim de ilustrar as hipóteses que conjecturamos, e mais precisamente de que a função do educador funciona como um pêndulo entre o Desejo e o Nome, trazemos no próximo subitem recortes da história de Helen Keller e Anne Sullivan, resgatada como exemplo contrastante do que, em geral, é pregado como ideal para a prática educativa contemporânea, numa educação que se deu não pelo viés discursivo obsessivo, muito menos ortodoxo, mas a partir de outro assento, com tentaremos demonstrar enquanto evocamos a presença de ambas.

Fazemos saber que utilizamos as seguintes fontes: The miracle worker, filme inspirador desta dissertação; A história de minha vida $(1903)^{55}$, primeiro dentre os doze livros publicados por Keller, Lutando contra as Trevas: minha professora Anne Sullivan Macy ${ }^{56}$, escrito em homenagem, editado em 1957, 21 anos após o falecimento da mestra; e Minha vida de mulher (1929) ${ }^{57}$. A escolha justifica-se por entendermos que ao material possa ser atribuído o que está na ordem de uma enunciação, da palavra plena ${ }^{58}$. Tanto filme, quanto os livros, embora não sejam fontes rigorosamente acadêmicas, não deixam de ser documentos fabricados com o consentimento e assinatura de ambas - Sullivan e Keller. Tentaremos, assim, mostrar sua singularidade, marcada pela autenticidade informal comum a diários e cartas produzidos sem maiores pretensões, muitas vezes para si mesmas, amigos ou familiares, ora como desabafos, ora como pedidos, exercícios de escrita, de pensamento, correspondência do dia a dia em época que ainda não havia "e-mails", nem sequer telefone fixo. 59

\footnotetext{
$553^{\text {a }}$. Edição brasileira, 1943.

${ }^{56}$ Primeira edição brasileira, 1959.

${ }^{57}$ Primeira edição brasileira, 1953.
}

${ }^{58}$ Palavra plena: Lacan, no seminário 1 sobre os Escritos Técnicos de Freud afirma "a palavra plena é aquela que visa, que forma a verdade tal como ela se estabelece no reconhecimento de um pelo outro. A palavra plena é a palavra que faz ato. Um dos sujeitos se encontra, depois, outro que não o que era antes. É por isso que essa dimensão não pode ser eludida na experiência analítica”. Lacan, 1990, p. 129.

${ }^{59}$ A invenção do telefone fixo foi devidamente registrada - ou patenteada - em 1876, por Alexander Graham Bell, um escocês que, na verdade, estava pesquisando aparelhos para deficientes auditivos, pois sua mãe não escutava bem. Assim, Bell acabou inventando um meio de comunicação para fazer as pessoas conversarem a distância. Não por acaso, foi ele quem indicou aos pais de Helen Keller os caminhos que permitiram chegar a Anne Sullivan, a quem Keller se referia, sempre, como "A professora”. 
Mais ainda à frente, Miguilim e o menino de Infância de Graciliano Ramos serão chamados para quando tratarmos das funções materna e paterna e seus desdobramentos conceituais do Desejo da mãe e do Nome do Pai, naquele que deverá ser o último capítulo.

\subsection{Anne Sullivan e o assento construtivista-sócio-interacionista}

Foi nas aulas de Psicologia da Educação $I^{60}$ do curso de Pedagogia, que tomei conhecimento do filme The Miracle Worker $^{61}$, quando terminávamos o primeiro bloco da disciplina, organizado em torno da teoria de Vygotsky a respeito da gênese do psiquismo humano, em seu contexto histórico-cultural, centrado no paradigma do desenvolvimento. A exibição tinha por objetivo ilustrar o fundamento do que aqui chamamos de teoria sóciohistórica das aprendizagens, em si um discurso, de modo a ressaltar a importância da mediação simbólica feita pelo professor no processo de desenvolvimento psicointelectual da criança. Tratava-se da história da educação de uma menina surda-muda que ascendia à linguagem somente depois de uma professora conseguir fazê-la entender que determinados sinais, feitos em sua mão, remetiam a um específico referente. Fazia-se assim, para Keller, o primeiro elo verbal entre objeto e signo, da palavra e do referente "water". Através da mediação simbólica que exercera junto a Helen, Anne Sullivan havia conseguido que entendesse e pudesse aprender, dali em diante, a comunicação da linguagem pelos sinais das mãos, por ter intervindo na zona proximal de desenvolvimento na qual a menina se encontrava.

Terminada a exibição, porém, os pensamentos que haviam andado no semestre anterior nas primeiras incursões aos estudos psicanalíticos ${ }^{62}$ e matutavam, ainda, sobre a educação fracassada de Victor de Aveyron $^{63}$, abalados novamente, não paravam de

\footnotetext{
${ }^{60}$ Ministradas por Marta Kholl de Oliveira, cuja produção escrita versada sobre a psicologia educacional não raro é recomendada na formação de professores. Seu livro intitulado Vygotsky: aprendizado e desenvolvimento: um processo sócio-histórico, editado pela editora Scipione, em 1997, figura na maioria das bibliografias de concursos públicos para seleção de educadores.

${ }^{61}$ A primeira versão de The miracle worker (O milagre de Anne Sullivan), em preto e branco, foi filmada em 1962 e ganhou dois Oscars pelas excelentes atuações de Anne Bancroft e Patty Duke. Indicado ainda para as categorias de melhor diretor, melhor roteiro adaptado e melhor figurino, o filme, de fato, para além do interesse educativo, carrega uma beleza singular, tanto pela fotografia, quanto pelo roteiro suspicaz.

${ }^{62}$ Psicologia da Educação II, ministrada por Leandro de Lajonquière.

${ }^{63}$ Conhecida pela tela de Garoto Selvagem, de François Truffault, 1970, assim como pela leitura de $A$ Educação de um Selvagem : as experiências pedagógicas de Jean Itard, organizado por Luci Banks-Leite e Izabel Galvão, São Paulo, Cortez, 2000.
} 
perguntar a eujemoi até que ponto conseguiriam aceitar Anne Sullivam como uma educadora sócio-interacionista, quando a atuação educativa daquela parecera-lhe ir muito além. Porque havíamos visto naquelas cenas algo difícil de encaixar na teoria, algo meio amalucado, improvável de ser atinado como uma conduta educativa "adequada". Não, a conduta de Sullivan não nos parecera nem um pouco "adequada", embora profundamente pertinente. Paradoxo. Desencaixes. Como poderia ser e não ser? Essa passou a ser uma questão. Ou alguém aceita, nos dias de hoje, que um professor chegue a dar um tapa na cara de um aluno, dependendo das contingências ocorridas durante os trabalhos que estão sendo elaborados; ou que uma professora peça permissão à família para passar alguns dias isolada com uma aluna em uma casa distante, a fim de fazê-la aprender a respeitar-lhe, principalmente quando diz-lhe “não"? Não, nada disso seria suportado, senão execrado, porque "desrespeitaria os direitos da criança e do adolescente". Tivesse Helen sido respeitada "adequadamente" em seus direitos de criança, possível que jamais ascenderia à fala... como também jamais teria feito tudo o que fez, tornando-se o significante que ainda hoje é no universo dos surdo-mudos. Tão pouco estaríamos aqui, depois de décadas, tentando reavivar esta que fez história na pedagogia moderna.

Pois bem, se saímos em busca de circundar a função do educador, e esse é aqui o nosso propósito, a nossa pergunta de pesquisa, sigamos primeiro nos caminhos conceituais propostos por uma das vias da Psicologia da Educação do curso da pedagogia costumeira, para então mostrarmos uma outra vertente de análise.

No contraponto aos pensamentos de Dona Cabeça ${ }^{64}$, Khol chamava a atenção dos graduandos para a importância crucial daquele momento de significação nas aprendizagens posteriores de Helen Keller visto que, de acordo com a teoria sócio-interacionista vygotskyana, dali em diante a menina estaria apta a aprender não só uma infinidade de palavras, como a própria fala, ambas fundamentais para o desenvolvimento do pensamento verbal, conforme podemos encontrar em Pensamento e Linguagem:

A relação entre pensamento e a palavra é um processo vivo: o pensamento nasce através das palavras. Uma palavra desprovida de pensamento é uma coisa morta, e um pensamento não expresso por palavras permanece na sombra. A relação entre eles não é, no entanto, algo já formado e constante; surge ao lado do desenvolvimento e também se modifica (VYGOTSKY, 1991, p. 131).

\footnotetext{
${ }^{64}$ Permitir a intervenção do que se aproxima de um narrador-personagem é um recurso que desenhamos para que o leitor possa realizar como foi acontecendo o que a autora entende como seu processo de equilibração majorante para a hipótese que construiu. Que não seja comum ao meio acadêmico, sabemos bem, que invalide nosso percurso de pesquisa e escrita, esperamos que não.
} 
Em Vygotsky, o pensamento não é entendido simplesmente como algo expresso em palavras, mas como um processo, um movimento contínuo de vaivém do pensamento para a palavra e vice-versa, de modo que somente por meio delas o pensamento passa a existir (Idem, ibidem, p.108). Quanto ao elo entre palavra e significado, não seria este meramente denotativo ou associativo, dado que a associação entre palavra e significado, explica o autor, pode tornar-se mais forte ou mais fraca, enriquecer-se pela ligação com outros objetos de um tipo semelhante, expandir-se por um campo mais vasto ou até tornar-se mais limitada. Ou seja, a associação palavra-significado mostra-se passível de alterações quantitativas e externas, nisto que ele nomina como desenvolvimento do significado das palavras (Idem, ibidem, p. 105): “Os significados das palavras são formações dinâmicas, e não estáticas. Modificam-se à medida que a criança se desenvolve; e também de acordo com as várias formas pelas quais o pensamento funciona" (Idem, ibidem, p. 108).

Entendendo, finalmente, que as coisas do mundo são verbalizáveis, ter-se-ia aberto a Keller o caminho para que utilizasse e se desenvolvesse nas funções psicológicas superiores, o que desembocaria, por fim, no controle consciente do próprio comportamento, segundo o interacionista.

Vygotsky dedicou-se, principalmente, ao estudo daquilo que chamamos de funções psicológicas superiores ou processos mentais superiores. Isto é, interessou-se por compreender os mecanismos psicológicos mais sofisticados, mais complexos, que são típicos do ser humano e que envolvem o controle consciente do comportamento, a ação intencional e liberdade do indivíduo em relação às características do momento e do espaço presentes. [Através da linguagem] $\mathrm{O}$ ser humano tem a possibilidade de pensar em objetos ausentes, imaginar eventos nunca vividos, planejar ações a serem realizadas em momentos posteriores. Esse tipo de atividade psicológica é considerada "superior" na medida em que se diferencia de mecanismos mais elementares tais como ações reflexas (a sucção do seio materno pelo bebê, por exemplo), reações automatizadas (o movimento da cabeça na direção de um som forte repetitivo, por exemplo) ou processos de associação simples entre eventos (o ato de evitar o contato da mão com a chama de vela, por exemplo). (...) Esse modo de funcionamento psicológico, típico da espécie humana, não está presente no indivíduo desde o seu nascimento. (...) [devido que] as atividades psicológicas mais sofisticadas são frutos de um processo de desenvolvimento que envolve a interação do organismo individual com o meio físico e social em que vive. A aquisição da linguagem definirá um salto qualitativo no desenvolvimento do ser humano (OLIVEIRA, 1997, p. 29, acréscimos nossos).

A abordagem vygotskiana elenca a comunicação como fator decisivo tanto no desenvolvimento mental, quanto nas aprendizagens, devido ao desenvolvimento das funções psicológicas superiores estar atrelado à mediação simbólica realizada por meio de instrumentos e signos capazes de viabilizar as atividades psicológicas ditas voluntárias e 
intencionais. Uma vez que a mediação entre homem e mundo se dá a partir de instrumentos que o próprio homem constrói para atingir objetivos específicos, a linguagem poderia ser entendida como mais um desses instrumentos criados para fornecer "um suporte concreto para a ação do homem no mundo" (Idem, ibidem, p. 34), resumindo, a palavra seria, por excelência, "instrumento psicológico" de comunicação e pensamento, isto que é, sim, um paradigma.

\begin{abstract}
A invenção e o uso de signos como meios auxiliares para solucionar um dado problema psicológico (lembrar, comparar coisas, relatar, escolher, etc), é análoga à intervenção e uso de instrumentos, só que agora no campo psicológico. O signo age como um instrumento no trabalho (Idem, ibidem, p. 30).
\end{abstract}

Vejamos a distinção que Vygotsky faz entre instrumento e signo. Enquanto instrumentos são elementos externos ao indivíduo, voltados para fora, cuja função é provocar mudanças nos objetos e controlar processos da natureza, os signos, chamados de “instrumentos psicológicos", são orientados para o próprio sujeito, para dentro dele, internalizados, com a função de dirigirem-se ao controle de ações psicológicas, seja do próprio indivíduo, seja de outras pessoas (Idem, ibidem, p. 30). Eis o entendimento de signo adotado pelos interacionistas:

Signos podem ser definidos como elementos que representam ou expressam outros objetos, eventos, situações. A palavra mesa, por exemplo, é um signo que representa o objeto mesa; o símbolo 3 é um signo para a quantidade três; o desenho de um sanitário é um signo que indica "aqui é o sanitário masculino" (Idem, ibidem, p. 30).

Na concepção de Vygotsky, o ser humano cresce num ambiente social sendo a interação com outras pessoas essencial para seu desenvolvimento. Por conta disso, as funções básicas da linguagem que possibilitam tanto as trocas sociais, quanto as interpretações do mundo real seriam duas, o intercâmbio social (a comunicação com seus semelhantes) e o pensamento generalizante (agrupar as ocorrências de uma mesma classe de objetos, eventos, situações, sob uma mesma categoria conceitual). Por conseguinte, o significado das palavras é entendido como uma generalização, um conceito, e como tal, fenômeno e instrumento de pensamento. "Ao tomar posse da linguagem, inicialmente utilizada apenas com a função de comunicação, a criança passa a ser capaz de utilizá-la como instrumento (interno, intrapsíquico) de pensamento" (Idem, ibidem, p. 52).

- Tomar posse da linguagem, inicialmente, apenas com a função de comunicação...!?! mas como, se isso a pequena criança fará só e só se já tiver sido atravessada há tempos pela linguagem do Outro Primordial, convidada e aceita como foi a tomar lugar no Desejo-da- 
Mãe, apossando-se da linguagem que metatransmitiu um lugar de vida, não de morte, sem ser ainda, propriamente, uma linguagem de comunicação no sentido estrito da palavra...

Tomado a compreender a relação entre aprendizagem e desenvolvimento, assim como as características específicas desta inter-relação na idade escolar, percebe-se em “Aprendizagem e Desenvolvimento Intelectual na Idade Escolar” (Vygotsky, 2005) que a aprendizagem não só está em função da comunicação, mas também do nível de desenvolvimento alcançado:

É uma comprovação empírica, frequentemente verificada e indiscutível, que a aprendizagem deve ser coerente com o nível de desenvolvimento da criança. (...) podemos tomar tranquilamente como ponto de partida o fato fundamental e incontroverso de que existe uma relação entre determinado nível de desenvolvimento e a capacidade potencial de aprendizagem. Todavia quando se pretende definir a efetiva relação entre processo de desenvolvimento e capacidade potencial de aprendizagem, não podemos limitar-nos a um único nível de desenvolvimento. Tem-se de determinar pelo menos dois níveis, já que, senão, não se conseguirá encontrar a relação entre desenvolvimento e capacidade potencial de aprendizagem. Ao primeiro destes níveis chamamos do desenvolvimento efetivo da criança (...) [aquele] que se conseguiu como resultado de um específico processo de desenvolvimento já realizado (VYGOTSKY, 2005, p. 35, acréscimo nosso).

Portanto, haveria para o desenvolvimento psíquico da criança uma parte definida pela maturação do organismo humano, embora grande parte do processo fique a cargo de aprendizagens capazes de despertar funcionamentos psíquicos internos que, não fossem o contato do indivíduo com certo ambiente cultural, não ocorreriam. Essa concepção cristalizase, segundo Oliveira (1997, p. 58), na formulação do conceito específico da teoria vygotskyana de Zona de Desenvolvimento Proximal ${ }^{65}$.

É a partir da postulação da existência de dois níveis de desenvolvimento - o real e o potencial - que Vygotsky define a zona de desenvolvimento proximal como 'a distância entre o nível de desenvolvimento real, que se costuma determinar através da solução independente de problemas, e o nível de desenvolvimento potencial, determinado através da solução de problemas sob a orientação de um adulto ou em colaboração com companheiros mais

\footnotetext{
${ }^{65}$ Também traduzido como Zona de Desenvolvimento Potencial. "OO que uma criança é capaz de fazer com o auxílio dos adultos chama-se zona do seu desenvolvimento potencial. Isto significa que, com o auxílio deste método, podemos medir não só o processo de desenvolvimento até ao momento presente e os processos de maturação que já se produziram, mas também os processos que estão ocorrendo ainda, que só agora estão amadurecendo e desenvolvendo-se (...) Portanto, o estado do desenvolvimento mental da criança só pode ser determinado referindo-se pelo menos a dois níveis: o nível de desenvolvimento efetivo e a área de desenvolvimento potencial. Este fato, que em si mesmo pode parecer pouco significativo, tem na realidade enorme importância e põe em dúvida todas as teorias sobre a relação entre processos de aprendizagem e desenvolvimento da criança. Em especial, altera a tradicional concepção da orientação pedagógica desejável, uma vez diagnosticado o desenvolvimento" (VYGOTSKY, 2005, p. 37, negritos nossos).
} 
capazes'. A zona de desenvolvimento proximal refere-se, assim, ao caminho que o indivíduo vai percorrer para desenvolver funções que estão em processo de amadurecimento e que se tornarão funções consolidadas, estabelecidas no seu nível de desenvolvimento real. (...) Interferindo constantemente na zona de desenvolvimento proximal das crianças, os adultos e as crianças mais experientes contribuem para movimentar os processos de desenvolvimento dos membros imaturos da cultura (OLIVEIRA, 1997, p. 60).

Sendo assim, o papel da escola e do professor seria interferir nesta zona, evitando dirigir o ensino para etapas intelectuais já alcançadas, tentando atingir o alvo dos estágios de desenvolvimento psicointelectual ainda não incorporados, de modo a provocar avanços que não ocorreriam espontaneamente:

Um ensino orientado até uma etapa de desenvolvimento já realizado é ineficaz sob o ponto de vista do desenvolvimento geral da criança, [pois] não é capaz de dirigir o processo de desenvolvimento, senão que vai atrás dele. A teoria do âmbito do desenvolvimento potencial origina uma fórmula que contradiz exatamente a orientação tradicional: o único bom ensino é o que se adianta ao desenvolvimento (VYGOTSKY, 2005, p. 38, acréscimo nosso).

Ou seja, o ensino deveria adequar-se às etapas do desenvolvimento cognitivo para adiantar-se a ele:

O processo de ensino-aprendizagem na escola deve ser construído, então, tomando como ponto de partida o nível de desenvolvimento real da criança num dado momento e com relação a um determinado conteúdo a ser desenvolvido - e como ponto de chegada os objetivos estabelecidos pela escola, supostamente adequados à faixa etária e ao nível de conhecimentos e habilidades de cada grupo de crianças (OLIVEIRA, 1997, p. 62).

Etapas estas que podem ser avaliadas pelo professor, segundo Vygotsky, de acordo com o comportamento cognitivo do aluno:

O ponto de vista tradicional dá como certo que a única indicação possível do grau de desenvolvimento psicointelectual da criança é a sua atividade independente, e não a imitação, entendida de qualquer maneira. (...) As únicas provas tomadas em consideração para indicar o desenvolvimento psicointelectual são as que a criança supera por si só, sem ajuda dos outros e sem perguntas-guiadas ou demonstrações. Várias investigações demonstraram que este ponto de vista é insustentável. (...) A diferença substancial [em relação aos animais] no caso da criança é que esta pode imitar um grande número de ações - senão ilimitado - que superam os limites da sua capacidade atual. Com o auxílio da imitação na atividade coletiva guiada pelos adultos, a criança pode fazer muito mais do que com a sua capacidade de compreensão de modo independente. A diferença entre o nível das tarefas realizáveis com o auxílio dos adultos e o nível das tarefas que podem desenvolver-se com um atividade independente define a área de desenvolvimento potencial da criança (VYGOTSKY, 2005, p. 35-36, acréscimo nosso). 
Daí a suposta importância dos professores no desenvolvimento psíquico, como também nas transformações dos significados daquilo que a criança, até certo momento, só aprende a partir das experiências vivida, porque na escola, tais transformações (desenvolvimento de significados) ocorreriam a partir de definições, referências e ordenações retiradas de diferentes sistemas conceituais, mediadas pelo conhecimento já consolidado na cultura.

A criança que aprendeu a distinguir a lua da luz do abajur e da lanterna vai, agora, aprender que a lua é um satélite, que gira em torno da Terra, que satélite é um tipo de astro diferente de planetas e estrelas, etc. Novamente o significado da palavra transforma-se, tornando-se cada vez mais próximo dos conceitos estabelecidos na cultura (OLIVEIRA, 1997, p. 50).

Em suma, através da relação interpessoal concreta com outros homens, o indivíduo interiorizaria as formas culturalmente estabelecidas de funcionamento psíquico, fornecendo a matéria-prima para o desenvolvimento psicológico, num processo que não se configura como absorção passiva, mas de transformação e síntese: "Como se o indivíduo "tomasse posse" das formas de comportamento fornecidas pela cultura, num processo em que as atividades externas e as funções interpessoais transformam-se em atividades internas, intrapsíquicas" (Idem, ibidem, p. 38), motivo pelo qual pensamento e linguagem estariam intimamente ligados, já que a linguagem internalizada tornar-se-ia um instrumento do pensamento: falar induz pensar, pensar induz falar, mesmo que seja nesse "discurso interior", forma interna de linguagem.

A linguagem origina-se em primeiro lugar como meio de comunicação entre a criança e as pessoas que a rodeiam. Só depois, convertido em linguagem interna, se transforma em função mental interna que fornece os meios fundamentais ao pensamento da criança (VYGOTSKY, 2005, p. 39).

- Interessante, quase compatível... mas se fosse só uma questão de mediação simbólica como e por que a menina não "falava", se em torno dela, há 7 anos, havia tantos adultos em sua convivência? Ou aqueles pais e adultos não souberam fazer como a maioria que, em geral, trabalham sobre a dita zona proximal de desenvolvimento dos filhos sem saber?... E se fazem isso, porque aqueles familiares não conseguiram transmitir à menina a relação entre significado e referente de absolutamente nada?... Sullivan cunhou um anzol e com ele fisgou a menina... terá sido pela invenção e domínio de procedimentos metodológicos que sua ação engatou Helen como vagão?

Enfim, para os adeptos do sócio-interacionismo, Anne Sullivan há de ter trabalhado sobre a Zona Proximal de Desenvolvimento da criança, em princípio através da imitação, até que Helen finalmente pudesse entender aquele e outros conjuntos de movimentos feitos pelos dedos da professora em suas mãos, remetendo ao significado de certos objetos. 
- Ok, ok!... Sem dúvida que o filme encaixa-se às lentes vygotskyanas, todavia, sob os crivos da psicanálise, outros quadros podem ser configurados...

De fato, não foi inócuo que a menina tenha aprendido a relação das palavras aos referentes. Contudo perguntamos, como fez Sullivan para ensinar o referente de uma conjunção, de um advérbio de modo, um adjetivo, um artigo?, como explicar, ou fazer a criança entender o que é o "passado", ou "ou”, ou "continente?”, ou o que vem a ser o "sexo", a "morte"? Não, caro leitor, a tarefa não parece das mais simples, porque precisa de um belo gancho para enlaçar alguém nessas aprendizagens... água é água e continuará sendo água, até que não se comporte como o tero ${ }^{66}$, ave comum também na Argentina, citada por Oscar Masotta em O comprovante da falta (1987), cujo comportamento funciona de maneira parecida à dinâmica errante de significante-significado (S/s), que para Lacan, tal qual a ave, bota ovos num lugar, para depois cantar em outro....

Retomemos a história.

Quando Anne Sullivan chegou à casa dos Keller, encontrou uma menina já em estado de linguagem, pois mesmo sem falar, já "falava", fosse através de mímicas toscas, movimentos imprecisos, grunhidos, empurrões ou pontapés. Aos 7 anos, ainda que encerrada na escuridão, como ela mesma acaba escrevendo, não estava fechada em si, distava do autismo, o que nos certifica que A palavra já havia sido instalada e feito daquele organismo um sujeito do inconsciente, embora não conhecesse nem pudesse proferir, em nome próprio, uma palavra sequer. A partir do escopo psicanalítico, inferimos, o aparelho de linguagem em Helen já estava ali, instalado pelo desejo materno. Helen, frisamos, embora demonstrasse muita agressividade e veemência nas negações, não apresentava Distúrbios Globais do Desenvolvimento, como se diz na atualidade, e devia transitar, possivelmente, entre a fase fálica e a latência, não sabemos nem podemos precisar.

Lembro-me ainda do espanto causado não só a mim, mas aos colegas de classe, a cena em que Sullivan participa da primeira refeição junto aos Keller, recusando-se a aceitar que a menina continuasse comendo, de prato em prato, porções dos membros da família, recolhidos com as mãos. Enquanto Helen circulava a mesa compondo seu "jantar", Sullivan calada observava a cena em que todos comiam e conversavam com grande naturalidade, desfrutando daquele hábito comum do cotidiano familiar até o momento em que a menina chegou-lhe ao prato. Vigorosamente e para o espanto de todos - inclusive nosso -, Sullivan

\footnotetext{
${ }^{66}$ Tero é uma ave típica da América do sul. No Brasil é conhecida como quero-quero, tetéu, téu-téu, terémterém ou ainda espanta-boiada.
} 
segura as mãos de Helen, empurrando-a para fora da mesa, até com certa violência. Risos abafados entre a turma graduanda. Estranhamento. Estupefatos, os familiares recriminam a intolerante reação da professora, dizendo-lhe que deixasse a menina em paz, pois estava acostumada a comer daquela forma. "Mas eu não estou!", foi a resposta não muito polida, mas professada com a mesma tenacidade com que segurava os punhos da garota. Helen, desnorteada e com truculência, avança sobre a professora, tentando desvencilhar-se e bater nela, como faria em outras oportunidades ${ }^{67}$. Na sala de jantar da família, dá-se então a primeira luta física entre as duas, por conta da tentativa da Srta. Sullivan ensinar à menina os modos socialmente aceitos para sentar-se à mesa, comer do próprio prato com talheres e ainda fazer uso civilizado do guardanapo. A cena é impagável, com direito a bofetadas de ambos os lados, pega-pega em volta e por baixo da mesa, quebradura de louças, atiramento de comida ao chão, lançamento de talheres, algo bem próximo do pastelão dos Três Patetas. As alunas de pedagogia, inclusive esta autora, um tanto quanto atônitas, riam nervosamente, como se não acreditassem no que viam. Ao final, Anne Sullivan e Helen Keller, completamente despenteadas, amarrotadas e sujas chegam ao objetivo "pedagógico" estipulado pela professora desde o início: comer sentada à mesa, do próprio prato e com talher, para só levantar-se após dobrar o guardanapo e postá-lo sobre o móvel, como faziam as pessoas comuns e educadas daquela época. Entre as feuspianas, um certo ar de alívio e descrédito. No filme, a sala de jantar ao final daquela que havia sido uma atividade sem dúvida bastante “educativa e pedagógica", encontrava-se imunda, com objetos e comida espalhados por todos cantos. Eujemoi, iniciante nos campos da pedagogia, ainda sem bem acreditar no que tanto vira, perguntava-me por diversão se seria possível que aquilo tudo fosse atribuído a uma conduta pedagógica do tão aclamado e correto construtivismo-sócio-interacionista...

Pois bem, acontece que até chegarem ao famigerado momento "inaugural" da significação, no final do filme, muito havia ocorrido entre as duas personagens. Não fosse $A$ professora extremamente suspicaz no enlaçamento subjetivo daquele embate pedagógico, condição sine qua non para que as duas pudessem entrar pelas portas da transferência e

\footnotetext{
${ }^{67}$ Essa passagem é contada pela própria Helen no livro escrito em homenagem a Sullivan, Lutando contra as Trevas: "O fantasma (como a autora nomeia a criança que fôra) estava habituado a tomar o alimento de seu prato e do prato dos outros com as próprias mãos. Annie [apelido de Anne] Sullivan não podia admitir tal comportamento e surgiu logo uma briga, durante a qual a família se retirou da sala. Então o fantasma se portou como um demônio, dando pontapés, gritando, beliscando quem o queria libertar e quase jogando a professora fora da cadeira. Annie, porém, conseguiu forçá-la a comer com uma colher e a manter as mãos fora do prato. Então o fantasma atirou no chão o guardanapo; mas depois, de uma luta que durou uma hora, Annie fez com que a criança o apanhasse e o dobrasse. Certa manhã, o fantasma não quis sentar-se para aprender as palavras que nada significavam para ela e deu um pontapé na mesa, virando-a. Depois que Annie recolocou o móvel no lugar e insistiu em continuar a aula, os punhos do fantasma se ergueram como um raio e quebraram dois dentes da professora" (KELLER, 1959, p. 46, acréscimos nossos).
} 
contra-transferência, a precipitação do referido entendimento possivelmente não teria ocorrido jamais e não estaríamos aqui citando uma história da vida real, há muito quase esquecida. Rapidamente pude perceber que aquilo tudo aloucado, da cena, provavelmente, seria para ser relevado, deixado de lado, longe, bem longe das psicogêneses ensinadas em nome de Piaget e Vygotsky, porque estas não tinham muito a dizer sobre semelhantes condutas e comportamentos de educador e educando, talvez ficcionais, talvez desimportantes. O problema é que Dona Cabeça, em vez de obedecer e conseguir ignorar e esquecer, fez grudar aquilo em pensamentos para seguir ruminando, ruminando entre eujemoi ao encontro do que viria se precipitar entre o entrar e o sair, um ano à frente, em costuras de tempológico.

- Enfim! Que personagens ressurgidos são esses, Anne Sullivan e Helen Keller?

Keller muitos devem conhecer, senão de história, ao menos por nome.

- Foi uma mulher cega, não?...

Sim. Muito mais do que isso. Nasceu em 1880, na Tuscúmbia (EUA) e morreu em 1968, em Connecticut. Até os sete anos foi criada na casa dos pais, longe de qualquer instituição que se incumbisse de sua educação formal, quando então uma jovem de 21 anos, quase cega, deu início à escolarização daquela menina cega-surda que, para o espanto de muitos, chegaria a aprender francês e alemão, depois do inglês, sua língua-mãe. Sempre acompanhada por essa mulher, passou por diversas escolas para pessoas não-portadoras de necessidades especiais educativas, entre elas a Escola Cambridge para Moças, em Massachusetts, até bacharelar-se em filosofia na Universidade Radcliffe, em 1904. Keller, depois de formada, passou a escrever livros, mas também artigos para revistas e jornais, buscando ampliar formas de ganhar o próprio sustento, até mesmo no teatro de vaudeville, dramatizando com sua professora as histórias vividas em dupla.

Entre 1946 e 1957, viajaram a 35 países por conta de palestras que proferiam, participando de conferências e mesas-redondas. Recebiam homenagens, davam entrevistas, mobilizavam-se por arrecadar fundos para cegos e surdo-cegos, na luta pela melhoria das condições de vida e trabalho dessas pessoas que, na época, não tinham acesso a uma boa educação e viviam de forma dependente, reclusas em casas de repouso, asilos ou instituições para deficientes, excluídos da inserção social mais abrangente. 
De 1924 até sua morte, trabalhou na American Foudation for the Blind ${ }^{68}$ como conselheira em relações nacionais e internacionais. Conheceu diversos países da Europa, África e América e teve sua história contada em documentários, peças de teatro, livros e filmes. Em 1953, a convite do governo brasileiro e da Fundação para o Livro do Cego no Brasil, Keller realizou palestras no Rio de Janeiro e em São Paulo. Dentre os inúmeros artigos e livros que escreveu, foi do primeiro, traduzido para cinquenta idiomas, que selecionamos o seguinte trecho:

Não é sem hesitação que me ponho a escrever a história de minha vida. Experimento um receio supersticioso ao levantar o véu de névoa dourada que envolve minha infância. (...) Procurando coordenar as primeiras impressões, sinto que os fatos reais e a fantasia de minha imaginação se entrelaçam de tal modo que assumem, ante meus olhos, a mesma importância. Ao passo que me ficaram bem vivas algumas das impressões que precederam as trevas da minha noite eterna, aos dezoito meses, muitas das alegrias e das mágoas que depois tive quase desaparecidas de minha imaginação. (...) Disseram-me que ainda nos cueiros eu já dava mostra de minha natureza impetuosa e voluntária. Procurava imitar tudo o que via fazer os que me cercavam. Aos seis meses vejam que maravilha - dizem que eu balbuciava "How d'ye?" . Depois da moléstia, esqueci todas as palavras aprendidas no primeiro período de minha vida. A única que me ficou foi "water" (água), que pronunciei "wah-wah" até aprender a escrever. (...) Cedo porém chegou o fatídico fevereiro: veio a desgraça da doença que haveria de tornar-me cega e surda, sepultando-me na inconsciência de um recém-nascido (...) Não posso recordar-me do que se passou nos meses que se seguiram a minha enfermidade. Sei apenas que passava quase todo tempo no colo de minha mãe, ou agarrada as suas saias (...) Dedicava-me a estudar os objetos com a mão e a observar todos os movimentos em volta de mim, modo pelo qual compreendia muitas coisas. Não tardei a experimentar a necessidade de me comunicar com os outros, e comecei logo a expressar-me por meio de mímica muito simples. Fazia os sinais afirmativo e negativo com a cabeça (...) Aos poucos me acostumei ao silêncio e à treva, a ponto de pensar que o mundo era mesmo assim, até o dia que chegou aquela que deveria libertar-me. (...) Mesmo nos dias que precederam a chegada daquela que iria servir-me de professora, eu me distraía seguindo com a mão as cercas de buxo para ir colher os primeiros lírios e violetas desabrochadas que eu descobria apenas com o olfato. Ia refazer-me dos meus acessos de raiva, escondendo o rosto afogueado por entre a folhagem fresca. (...) Não consigo mais fixar a época em que percebi ser bem diferente dos outros. Posso, contudo, afirmar que foi antes da chegada de minha professora. Eu compreendia que minha mãe e suas amigas não se exprimiam por sinais como eu. Acontecia-me, por vezes, ficar entre duas pessoas que conversavam e, apalpando-as, ao impulso de uma necessidade interior, cheguei a descobrir que moviam os lábios. Acabei assim percebendo que elas dispunham de um meio de comunicar-se que me era estranho. Incomodava-me não poder compreendê-las. Comecei também, por minha vez, a mexer com os lábios, gesticulando freneticamente, sem obter resultado algum. Estes insucessos me punham num estado de cólera terrível: eu batia com os pés no chão e soltava gritos de raiva, até ficar completamente esgotada

\footnotetext{
${ }^{68}$ No Anexo C disponibilizamos uma série de imagens de Anne e Hellen, em diversos momentos de suas vidas, retiradas do site oficial desta instituição que até hoje é atuante. Disponível em : http://www.afb.org/ . Acesso $23 / 02 / 2011$.
} 
(...) Eu era forte e ágil e não tinha medo de brigar. Sabia querer, não hesitando em lutar com unhas e dentes para ter o que desejava.. O dia mais memorável de minha vida foi aquele em que a professora - Anne Mansfield Sullivan veio juntar-se a mim. Ainda hoje não posso deixar de extasiar-me com o mundo de sensações novas que tal acontecimento inaugurou em minha vida. Estávamos em 3 de março de 1887, três meses antes de eu completar 7 anos. (...) Acaso o leitor já se viu algum dia em pleno mar, num navio envolto pela cortina brancacenta de espesso nevoeiro? O navio parece que vai soçobrar a cada instante; a angústia aperta os corações; mas a sonda desce para tatear o fundo do mar, a bússola é consultada e todos os meios de salvamento entram em ação. Tal qual esse navio, assim foi minha vida até o dia em que começou minha educação, com a diferença de que eu não tinha sonda, não tinha bússola, nem qualquer outro meio de salvação. "Luz! Luz!" era o grito incompreendido de minha alma. Nesse dia, o astro luminoso raiou para mim (KELLER, 2001, p. 17-31).

\section{- ... Anne Sullivan, quem foi?}

Nasceu em Massachusetts, em 1866, morreu em Nova York, em 1936. Seus pais eram imigrantes irlandeses, paupérrimos e analfabetos. Aos 7 anos, teve a visão seriamente comprometida em razão de tracoma, doença oftálmica altamente contagiosa, causadora de comprometimentos na córnea e na conjuntiva, fotofobia, dor, lacrimejamento e a perda da visão.

Sua mãe morreu quando ela tinha oito anos de idade, deixando ainda dois outros filhos. O pai abandonou as três crianças, dois anos mais tarde e Annie jamais soube do seu paradeiro. A irmã mais moça, Mary, foi entregue a parentes enquanto Annie e o irmão de sete anos, Jimmie, foram enviados ao hospital do Estado, abrigo de indigentes em Tewksbury; Annie porque era rebelde e demasiado cega para ser útil e Jimmie porque se estava tornando irremediavelmente aleijado em conseqüência de tuberculose nos quadris.

Entraram no asilo em fevereiro de 1876 e Jimmie faleceu em maio. Annie permaneceu ali quatro anos. Ninguém de fora se interessava por ela e não possuía amigos, exceto os indigentes, seus companheiros. Foi um destes que lhe contou que havia escolas especiais para os cegos e à medida que os meses passavam - ela havia perdido a noção de tempo em Tewksbury aumentava-lhe o desejo de se instruir. Fugir ao abismo da degradação e da doença em que vivia parecia impossível até que o mau cheiro do asilo atingiu um ponto tal que a Junta Estadual de Caridade exigiu um inquérito. Os investigadores não a notaram. Os internados, porém, sabiam o nome do presidente e, quando os membros da comissão chegaram, Annie lançou-se ao seu encontro e sendo incapaz de distinguir um do outro, gritou: "Senhor Sanborn, senhor Sanborn, quero ir para a escola!"

Entrou na Instituição Perkins em outubro de 1880 e lá, aos 14 anos, começou sua instrução, aprendendo a ler com os dedos" (Nella Braddy Henney, in KELLER, 1959, p 13-14). 
Em 1886 graduou-se com destaque, sendo a oradora da turma. Dali em diante, para sobreviver, precisaria trabalhar e conseguir o próprio sustento, o que não era fácil para uma mulher naquelas condições de saúde e com temperamento um tanto quanto incomum:

In August of 1886, Michael Anagnos, Director of the Perkins School for the Blind, asked his star pupil, Anne, if she was interested in working for the Keller family in Tuscumbia, Alabama. He told her that their six-year-old daughter, Helen, had been deaf and blind since the age of 19 months because of a severe illness.

Since that time the baby had grown into a wild and increasingly uncontrollable child. The parents, Kate and Arthur Keller, had contacted the famous inventor and educator of the deaf, Alexander Graham Bell in Washington, D.C. for help. He, in turn, had put them in touch with the Perkins School for the Blind. ${ }^{69}$

Ao primeiro convite de emprego, aceitou. Recém-formada, sem experiência como professora e com grande comprometimento visual, chegou à casa dos Keller para dar início à educação formal de Helen, a fim de tentar-lhe o ensino da linguagem de sinais e do braile. Desse dia em diante, até o falecimento de Sullivan, ambas seguiram estudando e trabalhando juntas, residindo nas mesmas casas.

3 de março de 1887.

Perguntei onde estava Helen. Era com dificuldade que eu escondia a emoção desse momento. "Está ali", disse-me o capitão Keller, indicando uma menina de pé, à entrada da casa. "Ela sabe que estamos aguardando alguém e ficou inquieta desde que a mãe saiu para esperar a senhora". Mal pus o pé no degrau, a menina correu ao meu encontro com tal ímpeto que eu teria caído se o capitão Keller não estivesse atrás de mim para segurar-me. Helen apalpou meu rosto, meu vestido e a maleta de viagem, que me tirou da mão e procurou abrir. Como não abrisse facilmente, deteve os dedos no fecho, procurando o orifício da fechadura. Encontrando-o, voltou-se para mim e fez o gesto de dar volta numa chave. Sua mãe fê-la compreender que não devia mexer na maleta. Ela corou e ficou muito zangada quando a Sra. Keller quis tirar-lhe a bolsa das mãos. Distraí-a dando-lhe meu relógio. Ela se acalmou logo, e foi juntamente comigo para o meu quarto. Aí abri a maleta e ela começou a mexer, procurando, talvez, alguma coisa para si. (...) Era muito engraçado vêla pôr minha boina, virando-se e revirando-a na cabeça, diante do espelho, como se pudesse ver. (...) eu esperava encontrar uma menina pálida e franzina, Helen, porém, não é nada disso. É desenvolvida e forte, de movimentos desembaraçados. (...) É difícil descrever-lhe o rosto. Exprime inteligência, mas não tem mobilidade nem vida. (...) Raramente ri. (...) Não dá importância às carícias e até se mostra impaciente com elas. Exceto com as da mãe. Tem muito gênio e é muito voluntariosa; só seu irmão James tem procurado

\footnotetext{
69 "Em agosto de 1866, Michel Anagnos, diretor da Escola Perkins para Cegos, perguntou à aluna de destaque, se ela se interessaria por trabalhar para a família Keller na Tuscumbia, Alabama. Disse a ela que a filha do casal de 6 anos, Helen, tinha ficado surda e cega desde os 19 meses por conta de uma grave doença. Desde então, a criança havia crescido como uma criança selvagem e cada vez mais incontrolável. Os pais, Kate e Arthur Keller, haviam contatado o famoso inventor e educador de surdos, Alexander Graham Bell, em Washington D.C. para ajudá-los. Ele, em resposta, colocou-os em contato com a Escola". Fonte: http://www.afb.org/annesullivan/asmgallery.asp?GalleryID=12, acesso em 20/10/2010, tradução nossa.
} 
controlá-la. O grande problema que tenho a resolver é como discipliná-la, sem prejudicar-lhe a personalidade. Irei devagar, a princípio, procurando conquistar a amizade. Não usarei grande rigor, mas vou insistindo na obediência, desde o início. (...) Ela não fica quieta um só instante. Anda por todos os cantos, pondo as mãos em tudo, sem prestar grande atenção a coisa alguma. Pobre criança! Seu espírito tateia nas trevas. Suas mãos insatisfeitas e não-educadas destroem tudo o que apanham, porque não sabem o que fazer das coisas. Ela me ajudou a desarrumar a mala grande e ficou muito contente quando recebeu a boneca que as alunas do Perkins lhe mandaram. Aproveitei a ocasião para ensinar-lhe a primeira palavra. Procurei tirar-lhe a boneca para ensinar-lhe as letras da palavra $d-o-l-l$. Exasperei-a, e tive de forçá-la a sentar-se para fazer-lhe as letras na mão. Ela não o consentiu, lutando para libertar-se de mim, até que me cansei e decidi procurar acalmá-la. Deixei-a ir, mas não lhe dei a boneca. Como sabia que ela gostava muito de doces, fui buscar um de sua preferência. Mostrei-o a ela, escrevendo $c-a-k$-e em sua mão. Ela quis tomar o doce, mas eu o retirei, acariciando-lhe a mãozinha, onde escrevi novamente $c-a-k-e$. Afinal ela imitou meu gesto e eu the dei o doce que ela moeu num relâmpago, pensando, talvez, que eu quisesse tirá-lo. Fiz então o mesmo com a boneca. Ela escreveu as letras $d$-o-l e eu fiz o $l$ restante, dando-lhe a boneca. Ela fugiu com o presente, recusando-se a voltar à minha presença durante todo o dia. (...) Esta manhã Helen ficou muito intrigada ao perceber que eu estava escrevendo. Andou em volta de mim, apalpando o papel e metendo os dedos no tinteiro. Estes borrões são trabalho dela. (...) Não mostre essa carta a ninguém. Está muito sem capricho, porque tenho os olhos inflamados hoje. Há ainda muito o que dizer, mas falta-me tempo. Gostaria de expor-lhes o que estou fazendo com muito mais detalhes (Anne Sullivan, in KELLER, 2001, p. 193-4).

Estavam em 1887, portanto a Srta. Sullivan não tinha como atar-se às locomotivas das considerações educativas e pedagógicas derivadas dos estudos de Piaget (1896 - 1980) e Vygotsky (1896 - 1934), tidas no discurso pedagógico contemporâneo como imprescindíveis à educação ideal, rezadas nas bibliografias de concursos e seleções de professores, seja para a educação básica, quando não para o universitário. No frigir daquele momento, frente ao desafio de uma educação para além de especial, coube à jovem mulher tocar em frente com os recursos que dispunha, lançando-se ao desconhecido; haveria de suportar a empreitada à qual se dispusera não por filosofia, tampouco comiseração, senão pela mais absoluta necessidade financeira, embora o desenrolar dos acontecimentos - e isso faz parte de nossa hipótese pendular da função do educador - acabaria enodando-a, também, ao desejo em causa...

26 de janeiro de 1888.

Recebi o Boletim do Perkins, onde vejo que o Sr. Anagnos exagera sobre o meu trabalho, sem necessidade. Os fatos simples são mais convincentes. Para quê, por exemplo, adulterar minhas intenções? Ele sabe, você sabe e eu também, que minha vinda para cá não teve nenhuma finalidade filantrópica. Vim para cá tão-somente forçada pela necessidade de ganhar a vida, embora 
nem ele nem eu própria suspeitássemos que eu possuía dotes especiais para o trabalho (Idem, ibidem, p. 218).

Pouco podemos dizer sobre os estudos psicopedagógicos de Anne Sullivan. Cartas ou relatórios fazem referência apenas a certo Dr. Howe e, de passagem, a dois autores da área da psicologia, Perez e Sully, que talvez sejam James Sully (1842-1923), psicólogo inglês autor dos livros Teacher's Handbook of Psychology e Studies of Childhood e Bernard Perez, autor de livros sobre o desenvolvimento da criança. A única referência genérica feita por Keller em Lutando contra as trevas sobre os estudos da educadora na área psicopedagógica é para dizer o quanto Anne se interessava por livros sobre educação, embora não cite nenhum dos pensadores que já haviam deixado suas contribuições ao campo da educação, entre eles Montaigne, Comênio, Locke, Rousseau, Pestalozzi, Jean Itard, Herbart, Fröebel, Comte, Freud, Durkheim, Dewey, Whitehead e Maria Montessori, contemporânea de ambas.

Se Sullivan conhecia ou não o universo da psicopedagogia em voga da época, pouco pudemos saber, mas seus escritos deixam prova de que a moça, com certeza, sabia um tanto da vida de cegos e surdos, visto que experienciava em seu corpo e pela sua história um bocado daquele viver. $\mathrm{Na}$ interpretação de Lajonquière às turmas de graduação em 2007, se Sullivan deu conta de fazer o que fez, talvez não tenha sido tanto pela menina, em si, senão por si mesma, por não ter como não fazê-lo... para além do dinheiro, aquele trabalho acabou sendo uma forma de tentar acertar as contas com sua própria infância, com seu romance familiar, com a vida dura que tivera e, em última instância, com seus fantasmas, que alguns preferem traduzir como fantasias. Sobre sua infância e adolescência, conta Keller, $A$ professora pouco falava. Só aos 64 anos relataria a Helen os acontecimentos difíceis pelos quais passara, pedindo-lhe que jamais escrevesse sobre eles, em detalhes, nem os contasse a ninguém.

Antes de me contar sua história, a mestra dispensou a empregada pela tarde toda e acomodou num canto para que não nos estorvasse, o seu collie (...). Em seguida, sentamo-nos lado a lado e o terrível drama de seus primeiros anos começou a se desenrolar na palma de minhas mãos. Ali estava a bela, distinta e sensível mestra, conhecida no mundo inteiro, a personalidade a quem os grandes e os poderosos haviam prestado elevado tributo em minha presença, vertendo a narrativa de uma trágica infância passada entre seres humanos mergulhados na miséria, na degradação e na doença. (...) Identifiquei-me como o espírito de pesquisa da criança meio cega, solitária, que vivia naquele medonho ambiente e quase enlouqueci ao ouvir os terríveis soluços com que, após um silêncio de meio século, ela falou da morte de seu irmão Jimmie, ocorrida no asilo. Não pude dormir naquela noite, tão profunda era a angústia que sentia (KELLER, 1959, p. 122). 
A empreitada com a menina talvez tivesse a ver, dizemos, não com algo que se assemelhe ao furor pedagógico, descrito por Maud Mannoni em Educação Impossível (1997), mas com algo que Anne projetava e buscava levar adiante para si mesma, na tentativa de existir e elaborar um pai. Tal-vez. Realizem: Sullivan educou-se a quilômetros de distância das condições para uma educação tida e havida como ideal. E deu no que deu.

Sobre ela, afirmava Sr. Anagnos, diretor da Perkins School: "Desde cedo revelou bravura e tenacidade para lograr alcançar o que desejasse. Inspirada no exemplo do Sr. Howe, resolveu consagrar a vida à educação dos deficientes físicos" (Keller, 2001, p. 189). Nos seis meses que esperou a ordem de partida para Tuscúmbia, teria lido assiduamente toda obra do autor. No filme, é o livro desse senhor que a jovem consulta várias vezes, recomendando-o inclusive à mãe da menina.

- E quem foi esse doutor que não aparece nos livros de história da pedagogia, que jamais ouvimos falar, sobre quem Anne tanto se debruçara?...

Dr. Samuel Gridley Howe (1801-1897) nasceu em Boston, Massachusetts. Em 1824, logo depois de se formar em medicina, viajou para a Grécia para trabalhar como cirurgião do exército na guerra pela independência, a exemplo de Lord Byron, poeta romântico britânico. Depois de deixar a Grécia, a fim de completar estudos de medicina, foi estudar em Paris, onde acabou participando também da Revolução de julho de 1830. Sui generis, sua história é longa e mirabolante, certamente renderia interessante e ágil roteiro cinematográfico, pois o personagem central pareceu-nos deliciosa e lindamente amalucado. Contudo, contá-la em cronologia exata e completa alongaria por demais nossos volteios, o que nos obriga a pular certas passagens, sem maiores explicações de como, nem porque, ele que gostava tanto de lutas e revoluções, em certo momento "assenta a pua" e acaba dando um jeito de levantar recursos para receber, na casa de seu pai, crianças cegas para serem educadas. Era o começo de algo que muitos viram como insano, mas que se transformaria na Perkins School, instituição da qual foi diretor, substituído após a morte pelo já citado Sr. Anagnos. Além da criação dessa primeira escola na América, foi Howe quem abriu uma tipografia e organizou um fundo de impressão para cegos pela primeira vez nos EUA. Sua atuação é considerada fundamental na criação de um grande número de instituições de natureza similar em todo o país.

Interessante fazer notar que Anne Sullivan e Helen Keller, cada qual a seu tempo e depois juntas, feito vagões de trem, engataram nessa locomotiva de nome Howe e se transmutaram, cada qual a sua maneira, em locomotivas para tantos outros, em tantos lugares 
do mundo. O que transparece em filiação simbólica veio engatilhando, fazendo laço, lá de trás, entre sujeitos implicados em histórias que giram em torno da vida de pessoas com deficiências visuais, entre eles o próprio Grahan Bell, como descrevemos na nota de rodapé.

- ..., os enunciados encontram sua verdade nisso que é a dor de existir do sujeito...

Concluindo antes de concluir, para esta pesquisadora, Anne Sullivan não foi um protótipo de educadora construtivista-sócio-interacionista, tampouco se punha a guardar que a aluna construísse o conhecimento, quase que exclusivamente, a partir das experiências de vida, de uma maneira empírica. Nem por isso explicava as coisas em seus tim-tins, o que para ela, também não era erro, menos ainda pecado tradicional, caso acontecesse de impedir, vez ou outra, que a menina fizesse as descobertas por si mesma. Sullivan não fazia uso da partitura de hipotéticas diagnoses a respeito das Zonas de Desenvolvimento Proximal de sua educanda para, então, artesanar e tecer o que faria na intervenção educativa-pedagógica a que se propusera. Sullivan não seguia os métodos da pedagogia científica, por exemplo, como da contemporânea Maria Montessori, autora de Pedagogia científica: a descoberta da criança, cujo paradigma pedagógico era o mesmo de Jean Itard, este que se propôs a educar o menino dito "selvagem", também mudo, aparentemente surdo, entre 11 e 15 anos, encontrado por volta de 1800 numa floresta do sul da França, rememorado por Lajonquière no início da década de 90 em “O legado pedagógico de Jean Itard. A Pedagogia: ciência ou arte?"70.

70 Jean Itard foi um médico francês, residente do Instituto Nacional de Surdos-Mudos que, ao conhecer o menino encontrado nas florestas, tomou para si a incumbência de educá-lo, defendendo com convicção de que seria possível reintegrar o jovem à sociedade, embora não fosse essa a opinião de seu professor, Dr. Pinel. Embora tenha elaborado todo um programa de ensino, com objetivos e metas a serem alcançados em decorrência do método pedagógico que aplicaria ao aprendiz, não conseguiu resultados muito satisfatórios. Seis anos após o início dos trabalhos, no segundo relatório escrito ao Ministro do Interior, o médico-pedagogo admitia que pouco havia alcançado na educação daquele que, agora, já era um rapaz. Victor viveu até 1828, custeado pelo Estado Francês, sob os cuidados de uma governanta, Madame Guérin. Finalmente, desinteressado pelo garoto, Itard passou a se dedicar à educação dos surdos por quase quarenta anos, fazendo investigações nos campos da Otorrinolaringologia, da linguagem e de distúrbios como a gagueira e o mutismo.

No Brasil, após uma série de debates a respeito do tema promovidos pelo LEPSI- USP e de atividades semelhantes realizadas na Unicamp, foi lançada em 2000 a coletânea A educação de um selvagem, sob organização de Luci Banks-Leite e Izabel Galvão. Neste livro, o leitor pode encontrar, além de 6 ensaios, a importante tradução dos relatórios escritos por Itard ao governo francês.

Quase duas décadas depois de fazer publicar no Brasil o primeiro texto a respeito de Itard/Victor, Lajonquière volta a escrever sobre o caso, analisando o ideário que deu sustentação à iniciativa médicopedagógica de Itard e que, segundo ele, “ainda opera silencioso na memória genética comum à espécie dos pedagogos ortodoxos de hoje" (LAJONQUIÈRE, 2010, p. 122). Nesta que compôs como a terceira parte do livro intitulada Do que não deve ser feito ao que pode acontecer numa educação, o autor retoma e avança na análise da educação de Victor por Itard, como ainda, para nossa surpresa e alegria, oferece seus primeiros escritos sobre a experiência educativa de Helen Keller por Anne Sullivan, o que só foi possível graças às vicissitudes da vida do professor quando, finalmente, aceitou assistir ao filme com o qual havíamos perseguido-o por mais de três pares de anos, desde o início de nossa graduação. Na academia, por locomotivas e vagões a trilhar pela linha de nossas pesquisas, acabamos formando um casal muito fértil, apesar de improvável, sui generis e prá lá de antinômico: Jean Itard e Anne Sullivan. 
Anne não era psicóloga, não se nomeava pedagoga, menos ainda incipiente pesquisadora da educação especial de cegos e surdos, embora hoje saibamos que foi. Era simplesmente uma moça que não tinha família na retaguarda, precisando trabalhar para sustentar-se; dona de uma inteligência altiva, com limitações visuais graves, determinada, viril e que tomou para si o desafio de fazer uma menina cega-surda participar do mundo dos humanos como gente, sem expô-la como bibelô, aberração ou troféu. Destino bastante diferente do que foi reservado a Victor. Podemos dizer que pelo legado que deixou, Helen Keller tornou-se uma mulher que ex-istiu, basta ler seus livros, conhecer suas opiniões políticas, sua atuação e incursões pelo mundo. Quanto a Sullivan, o mesmo poderá ser dito. Sem rezar práticas instituídas legitimadas pelo discurso científico, acadêmico ou médico, sua implicação em causa respondia inventando artesanatos "pedagógicos" para um saber-fazer educ(a)tivo, - o que pode não parecer grande, embora seja, porque envolve autoria e estilo.

O que o discurso hegemônico contemporâneo tem por certo e incorpora como Zona de Desenvolvimento Proximal, tipo de campo de excelência para a intervenção pedagógica, tentamos pensar como a interface do reconhecimento de um estilo, no sentido de que o estilo é o Outro a quem nos dirigimos, como veremos pouco mais à diante. Se discordamos, pela via da psicanálise, que o sujeito se desenvolva tal qual uma mônada, como trabalhar "pedagogicamente" o cognitivo em nome das Zonas Proximais de Desenvolvimento?... seria um contra-senso... Mesmo porque o próprio mecanismo cognitivo da equilibração majorante $^{71}$ descrito por Piaget e relembrado por Lajonquière, recalcado pelos psicopedagogos, entretanto, é fundamental, embora funcione de maneira incerta e imprevisível, fazendo admitir a existência daquele operador tero tanto no ensinar, como no aprender, motivo pelo qual, mais comum do que seria desejável, endereçamos uma aprendizagem aqui e o efeito saia refratado ${ }^{72}$ acolá. Que a mediação tenha um lugar de importância reconhecida, não contestamos, no entanto podemos entendê-la por outro crivo.

Estas mediações são de diversos tipos e o conjunto delas recebeu, em Lacan, o nome de simbólico, ou de ordem simbólica. Num primeiro momento, Lacan considerou que esta mediação poderia ser o trabalho ou a luta por fazer reconhecer e por reconhecer-se nos Ideais do Eu. Esta mediação seria

\footnotetext{
${ }^{71}$ Piaget nomeia equilibração majorante o princípio funcional da gênese epistêmica. Segundo Lajonquière em "Para se ler De Piaget a Freud", o próprio Piaget "demonstrou que a estruturação cognitiva não é passível de "aceleração" empírica, bem como que a lógica construtivista das epistemes não responde linear e mecanicamente às intervenções "externas", pois há em operação no interior do processo um inconsciente cognitivo.” In: De Piaget a Freud: para uma clínica do aprender. Petrópolis: Vozes, 2010.

${ }^{72}$ Ver CAMARGO, A. C. C. S. Demanda educativa, retornos e a inoperância dos métodos de ensino. In: VI Colóquio LEPSI de Psicanálise e Educação, 2006, São Paulo. An 6 Col. LEPSI IP/FE-USP 2006, 2006.
} 
exemplificada pela passagem do sujeito da família à sociedade. Logo Lacan substitui esta ideia pela tese de que o mediador principal a ser reconhecido na relação intersubjetiva é o desejo. O desejo é o desejo de reconhecimento, é desejo de ter seu desejo reconhecido, e por isso, ele é desejo de desejo do Outro. Aqui começa a surgir um dos principais atributos do simbólico em Lacan, a saber, a negatividade. É pelo trabalho da negatividade que o desejo progride. A positivação do desejo em um objeto corresponde a sua alienação neste objeto ${ }^{73}$ (negrito nosso).

- Positivação do desejo em um objeto..., o perdido objeto a... ter o desejo reconhecido pelo desejo do Outro na alienação ao objeto causa de desejo... essa a matéria-prima daquele anzol ?...

O estilo, digamos, é o que em nosso modelo hipotético funcionaria como pino e encaixe para o pequeno $a$, lugar por onde o pêndulo da função do educador se pendura, possibilitando que um vagão/sujeito enlace-se a outro, este que serve de locomotiva - ou de mestre, analista, histérico(a) - viabilizando no aprender o trabalho inconsciente aberto às vicissitudes da equilibração majorante, quando o sujeito ao mesmo tempo que circula os objetos do conhecimento, segue em busca do pequeno $a$ em causa, detalhe que nos fez grafar educ(a)tio, tal qual fez Lacan com o a alocando-o no vazio central do nó borromeano. $^{74}$

Em suma, o modo de endereçamento de Sullivan a Helen distava do discurso da pedagogia científica de Maria Montessori, da psicopedagogia ortopédica de Itard ou do sócio-construtivismo atual, esses que entendemos como vagões bacomenianos. Não eram esses os assento de seu discurso. Embora estudasse com afinco um certo Dr. Howe, o discurso daquela moça distava da matriz obsessiva, nem era anônimo, menos ainda de uma

\footnotetext{
${ }^{73}$ DUNKER, C. I. L.. Introdução à Psicanálise Lacaniana, conceitos e contextos. Texto cedido pelo autor.
}

74 Segundo Roudinesco e Plon, o nó borromeano é um modelo estrutural, fundamentado na topologia e efetuando um deslocamento radical do simbólico para o real. "Foi em 9 de fevereiro de 1972 que surgiu pela primeira vez no discurso lacaniano a expressão nó borromeano, que remetia à história da ilustre família Borromeu. As armas dessa dinastia milanesa, com efeito, compunham-se de três anéis em forma de trevo, simbolizando uma tríplice aliança. Se um dos anéis se retirasse, os outros dois ficariam soltos, e cada um remetia ao poder de um dos três ramos da família. A partir dessa data, os exercícios topológicos baseados no trançado de nós, cada qual simbolizando um elemento da trilogia (real/simbólico/imaginário), começaram a assumir um lugar considerável no ensino lacaniano." (1998, p. 541) . Na definição evocada por Lacan no seminário 19 ... Ou pior (1971-72), "Cadeia de três e tal que em se destacando um dos seus anéis os dois outros já não podem se manter ligados". "Na cadeia borromeana 'clássica' (a três), todos os elos estão em igualdade de posição: em se desamarrando um deles, todos se soltam. Lacan conseguia enfim uma forma de apresentar as três instâncias do sujeito da linguagem: Real, Simbólico, Imaginário, sem uma "hierarquia" entre si. No centro seria o lugar de seu objeto a - o objeto causador de desejo - lugar vago, e ao mesmo tempo tão cobiçado". VICTORA, Ligia Gomes, in "Oficina de Topologia - O nó borromeano de Lacan”, Associação Psicanalítica de Porto Alegre. Disponível em:

http://webcache.googleusercontent.com/search?q=cache:9GgdVNbfkJoJ:www.appoa.com.br/noticia detalhe.php \%3Fnoticiaid \%3D65\%26PHPSESSID\%3D4ce5a9d2a3ca8ada1ca646d575385143+objeto $+\mathrm{a}+$ no + centro $+\mathrm{n} \% \mathrm{C} 3$ \%B3+borromeu\&cd=1\&hl=pt-BR\&ct=clnk\&gl=br . Acesso 3/10/2010. 
tecnocrata da para-educação. Seu trabalho tinha uma autoria, possivelmente combinada pelos tons dissonantes de sua palavra, e do jeito um tanto excêntrico de ser... Possivelmente, matizes do giro discursivo em que professava ora como histérica, ora como mestre, ora universitária, ora sujeito suposto saber. Impregnâncias.

Como psicanalista, estou destinado a me interessar mais pelos processos emocionais que pelos intelectuais, mais pela vida mental inconsciente que pela consciente. Minha emoção ao encontrar meu velho mestre-escola adverte-me de que antes de tudo, devo admitir uma coisa: é difícil dizer se o que exerceu mais influência sobre nós e teve importância maior foi a nossa preocupação pelas ciências que nos eram ensinadas, ou pela personalidade de nossos mestres. É verdade, no mínimo, que esta segunda preocupação constituía uma corrente oculta e constante em todos nós e, para muitos, os caminhos das ciências passavam apenas através de nossos professores. Alguns detiveram-se a meio caminho dessa estrada e para uns poucos - porque não admitir outros tantos? - ela foi por causa disso definitivamente bloqueada.

Nós os cortejávamos ou lhes virávamos as costas; imaginávamos neles simpatias e antipatias que provavelmente não existiam; estudávamos seus caráteres [caracteres] e sobre estes formávamos ou deformávamos os nossos. Eles provocavam nossa mais enérgica oposição e forçavam-nos a uma submissão completa; bisbilhotávamos suas pequenas fraquezas e orgulhávamos-nos de sua excelência, seu conhecimento e sua justiça. No fundo, sentíamos grande afeição por eles, se nos davam algum fundamento para ela, embora não possa dizer quantos se davam conta disso. Mas não se pode negar que nossa posição em relação a eles era notável, uma posição que bem pode ter tido suas inconveniências para os interessados. Estávamos, desde o princípio, igualmente inclinados a amá-los e a odiá-los, a criticá-los e a respeitá-los. A psicanálise deu nome de 'ambivalência' a essa facilidade para atitudes contraditórias e não tem dificuldade em indicar a fonte de sentimentos ambivalentes desse tipo (FREUD , 1996 [1914], V. XIII, p. 248, acréscimo nosso).

- A propósito I: locomotiva, nos elementos de sua composição, tem-se loc (de lócus, local) + mov (idéia de movimento).

- A propósito II: pedagogo: ped (lançar-se, buscar, tentar atingir, aproximar-se, alcançar, desejar, requerer, solicitar) + agogo (nas minas da Antiguidade grega e romana, aquedutos, canais construidos para dar vazão às águas. Novamente, a idéia de ducto/de eductio. Pedagogo: o que lança-se a buscar, atingir, solicitar, o ducto, o canal para dar vazão e fazer anzóis e engates?). 
8 de maio de 1887.

Agora não preciso mais do meu material de jardim-de-infância. Entendo que é melhor trazer as crianças em contato com a natureza, deixando que elas escolham e associem suas impressões. Num ambiente fechado, sentada ao pé da professora de voz meiga, que lhe manda fazer muralhas e torres com blocos de madeira ou arco-íris com tiras de papel de cor, elas adquirem noções artificiais. Helen está aprendendo os adjetivos e advérbios com a mesma facilidade com que aprendeu os substantivos. A ideia precede sempre a palavra. Muito antes de me conhecer, ela já tinha sinais próprios para indicar 'grande' e 'pequeno'. Quando queria um objeto pequeno e the traziam um grande, segurava um pedacinho da pele da mão esquerda entre o polegar e o indicador da direita. Quando queria uma coisa grande, abria bem os dedos de ambas as mãos em concha, aproximando uma da outra, como se quisesse segurar uma bola grande. (...) Hoje pela manhã, empregou a conjunção "e" pela primeira vez. (...) Desde que comecei o ensino livre, pelas coisas da natureza, tenho notado que Helen aprende muito mais depressa. Penso que é desperdiçar tempo ficar interrogando o aluno sobre a lição anterior, só pelo prazer de sentir que ela aprende o que lhe ensinamos. Parece-me mais razoável supor que o aluno vai bem e que a semente que lançamos hoje germinará um dia. É muito melhor para a criança e evita muitas amolações (Anne Sullivan, in KELLER, 2001, p. 202-3).

\subsection{Os discursos em Lacan e em Anne Sullivan}

\subsubsection{A estrutura do discurso}

O que a análise mostra, se é que mostra alguma coisa (...) é precisamente isso, não se transgride nada. Entrar de fininho não é transgredir. Ver uma porta entreaberta não é transpô-la. (...) não se trata de transgressão, mas antes de irrupção, queda no campo de algo que é da ordem do gozo - um bônus (LACAN, 1992, p. 18).

Segunda-feira à tarde.

Nesta manhã tive que lutar com Hellen. Procuro evitar essas cenas o quanto posso, mas nem sempre o consigo. Ela não é quietinha como parece. Durante as refeições, fica metendo a mão no prato dos outros, beliscando pedacinhos e comendo. Hoje começou a fazer isso comigo, e entendi que não devia consentir. Ela embirrou muito e tive de contrariá-la. Foi uma coisa horrível. A família saiu da mesa. Fechei a porta e fiquei sozinha com a menina procurando comer, mas a comida quase não me passava na garganta. Helen 
deitou-se no chão, gritando, debatendo-se e procurando puxar minha cadeira. Ficou assim por meia hora, levantando-se depois para ver o que eu estava fazendo. Deixei-a perceber que estava comendo, mas não consenti que pusesse a mão no meu prato. Ela começou a beliscar-me e eu ia dando-lhe um tapinha a cada beslicão. Saiu então, apalpando em volta da mesa, e vendo que não havia ninguém, ficou pensativa. Veio sentar-se em seu lugar e começou a comer com os dedos, atirando ao chão a colher que lhe dei. Tirei-a da cadeira com força, fazendo-a apanhar a colher. Forcei-a a pegar no talher e levá-la à boca, até que ela resolveu comer por si mesma. Tive ainda de lutar para fazê-la dobrar o guardanapo. Para ver-se livre de mim, atirou-o no chão e saiu correndo para a porta. Como, porém, achou-a fechada, começou a dar pontapés e a gritar desesperadamente. Foi uma trabalheira fazê-la voltar e dobrar o guardanapo. Deixei-a brincar ao ar livre, subi para meu quarto, exausta, chorei muito e fiquei aliviada. Adeus, minha querida; não fique preocupada comigo, que hei de levar adiante a tarefa que me impus (Anne Sullivan, in KELLER, 2001, p. 194).

Vejamos como a teoria psicanalítica sobre o discurso nos ajuda a pensar o assento da palavra de Sullivan endereçada a Helen.

Entre 1969 e 1970, Lacan profere a teoria dos quatro discursos - do ${ }^{75}$ mestre, da histérica, da universidade e do analista, - publicada em 1991 sob o título O Seminário 17: o avesso da psicanálise. Pareá-la à análise do discurso da lingüística ou da comunicação de Michel Pêcheux, Mikhail Bakhtin, Michel Foucault, dentre outros, seria um equívoco. Da teoria da análise de discurso proposta por Lacan, não se privilegia a análise de figuras de conteúdo, mas principalmente dos aspectos formais (cf. Dunker, 2005). "O discurso deve ser considerado basicamente como um sistema de circulação e repetição. Isso significa que das infinitas possibilidades de expressão e criação, oferecidas pela linguagem, poucos são os lugares necessários para delimitar sua estrutura" (Idem, ibidem). O que Lacan chamou de discursos foram as formas das pessoas se enlaçarem socialmente, interessado para além da palavra, ou seja, na estrutura da linguagem - já que é possível discursar sem palavras - e, em última instância, no campo do gozo. Por conseguinte, os discursos são modalidades de laço social, mas também de gozo, de endereçamento.

Mesmo que não se diga nada, no momento em que se está dentro de uma relação com outra pessoa, se está inserido num discurso em que os atos importam mais do que as palavras, onde aparecem modalidades de gozo distintas (...) [e como] o campo do gozo é, antes de tudo, um campo operatório e conceitual 'aparelhado' pela linguagem, os aparelhos para tratar o

\footnotetext{
75 “(...) o sentido do genitivo objetivo: o discurso do mestre é o discurso sobre o Mestre (...). O discurso do analista é a mesma coisa, fala-se do analista... (LACAN, Seminário de 1971-72 - Colóquio de Sainte-Anne sobre Le savoir du psychanalyste).
} 
gozo são os laços sociais, que Lacan denomina 'discursos' (QUINET, 2001, acréscimo nosso $)^{76}$.

O discurso como laço social é um modo de aparelhar o gozo com a linguagem na medida em que o processo civilizatório, para permitir o estabelecimento das relações entre as pessoas, implica a renúncia da tendência pulsional em tratar o outro como um objeto a ser consumido: sexualmente e fatalmente. Pois a inclinação do homem é ser o lobo do outro homem, ou seja, abusar dele sexualmente, explorá-lo, torturá-lo, matá-lo saciando no outro sua pulsão de morte erotizada. A civilização exige do sujeito uma renúncia pulsional. Todo laço social implica um enquadramento da pulsão resultando em uma perda real de gozo. Todo discurso é, portanto, um aparelho: aparelho de gozo (QUINET, 2002, p. 32).

O campo do gozo com seus discursos, seria a resposta de Lacan ao mal-estar na civilização elaborada depois de maio de 68 na França, na contestação geral da autoridade. Em o Mal-Estar na Civilização, Freud afirmava ser a relação entre as pessoas a maior fonte de sofrimento humano; na retomada do texto freudiano, Lacan passa a representar esse malestar com aquilo que nomina "objeto $a$ ", ou pequeno $a^{77}$, parte integrante da teoria dos quatro discursos, elemento heterogêneo que expressa a parte excluída da linguagem, tudo aquilo que a civilização exige que o homem renuncie - os objetos de suas pulsões - por conseguinte, o mal-estar justamente acaba precipitando por este resto de real que advém dos laços sociais.

Para Elizabeth Roudinesco, entretanto,

Essa nova teoria da discursividade não fazia senão prolongar uma interrogação que perseguia Lacan (...) como se constrói o amor das massas pelos tiranos? Por que toda "libertação" é impossível fora de uma adesão à lei? Em outras palavras: diante de Sartre, e na linha direta do ensinamento foucaultiano, Lacan colocava a questão da essência da liberdade humana do ponto de vista da descoberta freudiana: como pode um sujeito pretender a liberdade quando ele é determinado pela existência de um inconsciente que o impede de ser livre em seus atos e em suas palavras, mas jamais o impede de engajar-se em favor de um combate pela liberdade, etc? Em vez de responder, ele entregava-se a uma longa meditação sobre a natureza da revolução (...) Afirmava que a revolução sempre acabava por engendrar um mestre mais feroz que o que ela havia abolido. A propósito dos acontecimentos de maio, sublinhava que a contestação conduzira à supressão na universidade da antiga função do mestre para substituí-la por um sistema tirânico fundado no ideal da comunicação e da relação pedagógica. Nada mais verdadeiro, já que se sabe hoje que a revolução das barricadas foi um dos momentos da substituição, na universidade, dos intelectuais pelos tecnocratas (ROUDINESCO, 2008, p. 470-471).

\footnotetext{
${ }^{76}$ Textos obtidos pela internet nem sempre se encontram subdivididos em páginas, motivo pelo qual, em algumas citações, o número da(s) mesma(s) não consta $(\mathrm{m})$ especificado(s). Em outros, cedidos pelos próprios autores, o mesmo pode ocorrer, como na citação de Dunker (2005), feita no parágrafo anterior.
}

\footnotetext{
${ }^{77}$ Rever nota de rodapé 17 , pág. 26.
} 
Para tratar sobre os discursos, Lacan criou quatro matemas ${ }^{78}$, ou seja, algoritmos ${ }^{79}$, cada qual composto de quatro elementos constantes, posicionados de quatro maneiras diferentes, de forma que a variação da modalidade discursiva se altera de acordo com o lugar que cada elemento ocupa na estrutura fixa do discurso. São quatro lugares, cada qual com uma função: no lugar da verdade, função de verdade mesmo; no lugar do agente, função de semblante ${ }^{80}$; no lugar do outro, função do gozo ${ }^{81}$; no lugar da produção, função de maisde-gozar ${ }^{82}$. "Os lugares dos discursos são sempre fixos porque todo e qualquer discurso é sempre movido por uma verdade, sua mola propulsora, sobre a qual está assentado um agente, que se dirige a um outro a fim de obter deste uma produção" (COUTINHO JORGE, 2003, p. 46, grifo nosso).

A estrutura fixa do discurso foi montada por Lacan da seguinte forma:

\begin{abstract}
78 Matema é um tipo de escrita com letras e símbolos matemáticos, denominada pelo próprio Lacan álgebra lacaniana, cujo objetivo é atingir uma formalização de conceitos, uma escrita, capaz da transmissão integral de, ao menos, um mínimo daquilo que se decanta da experiência psicanalítica, (...) independente da fala daquele que a transmite (COUTINHO JORGE, 2003, p. 42-43).
\end{abstract}

${ }^{79}$ No Houaiss, há diversas acepções para algoritmo: sequência finita de regras, raciocínios ou operações que, aplicada a um número finito de dados, permite solucionar classes semelhantes de problemas (p.ex.: algoritmo para a extração de uma raiz cúbica) ; processo de cálculo; encadeamento das ações necessárias ao cumprimento de uma tarefa; processo efetivo, que produz uma solução para um problema num número finito de etapas; mecanismo que utiliza representações análogas para resolver problemas ou atingir um fim, noutros campos do raciocínio e da lógica; conjunto das regras e procedimentos lógicos perfeitamente definidos que levam à solução de um problema em um número finito de etapas.

${ }^{80}$ Semblante: Dimensão do que pode aparecer da posição subjetiva, na medida em que a psicanálise não opõe essa aparência a uma essência, mas a liga dialeticamente à verdade. (...) O semblante constitui bem a dimensão daquilo que aparece. Mas esta não deve ser desqualificada como tal. O semblante não é falso-semblante. Lacan diz mesmo que "o semblante que se dá, para aquilo que é, é a função primária da verdade" (Séminaire XVIII, D'um discours qui ne serait pas du semblant, 1971) (Roland Chemama. In: CHEMAMA ;VANDERMERSCH, 2007, p. 341) ; (...) o semblante ocupa esse lugar que a verdade supõe; a distorção entre sujeito e enunciado e sujeito da enunciação torna impossível a coincidência entre esses dois registros. Em seu discurso, o sujeito estará tão-somente representado, e ele articula um discurso de lugar-tenente em relação à verdade de seu desejo. A divisão do sujeito institui portanto uma falha aberta a todos os logros; o eu $(\mathrm{Je})$ que persiste no discurso oculta o sujeito do desejo. Os muitos lugares-tenentes pelos quais o sujeito se representa se atualizam em representações imaginárias ; o moi (eu imaginário) se toma pelo $J e$, dirá Lacan, construção que o estádio do espelho inaugura (KAUFMANN, 1996, p. 462).

${ }^{81}$ Gozo: "Raramente usado por Sigmund Freud, o termo gozo tornou-se um conceito na obra de Jacques Lacan. Inicialmente ligado ao prazer sexual, o conceito de gozo implica a ideia de uma transgressão da lei: desafio, submissão ou escárnio. O gozo, portanto, participa da perversão, teorizada por Lacan como um dos componentes estruturais do funcionamento psíquico, distinto das perversões sexuais. (...) o gozo não é apenas sinônimo de prazer, mas é sustentado por uma identificação e articulado como a ideia de repetição, tal como esta seria empregado mais tarde em Mais-além do princípio de prazer, por ocasião da elaboração do conceito de pulsão de morte" (ROUDINESCO ; PLON, 1998, p. 299).

82 (...) há um paralelo possível entre o estatuto fundamentalmente perdido do objeto, para o sujeito, e a maisvalia, designada por K. Marx como aquilo a que o trabalhador deve renunciar, mas também o capitalista, em sua maior parte, se ele deve reinvesti-la na produção. Daí o nome de mais-de-gozar, que Lacan dá, então, ao objeto $a$, em função dessa analogia (Roland Chemama, in CHEMAMA ; VANDERMERSCH, 2007, p.103). 


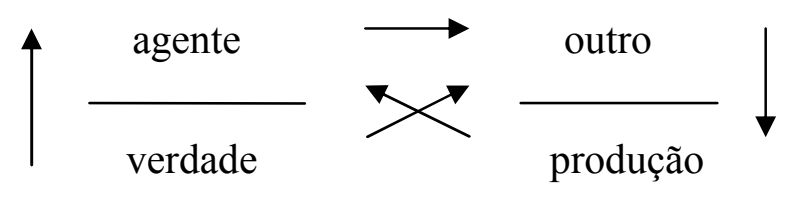

Quanto aos elementos que se alternam nos lugares fixos do discurso, Lacan nomeiaos: $\boldsymbol{S} 1$, ou significante mestre, referência singular para o sujeito que funciona como um selo, como marca fundadora que, segundo Maurano (2007), exerce um comando feroz sobre o sujeito e tem por função representá-lo no mundo da linguagem junto ao conjunto dos outros significantes, daí sua aptidão a promover o laço social; $\boldsymbol{S} 2$, ou o saber inconsciente, conjunto de significantes do Outro que sucede o $S 1$, compondo a cadeia da linguagem propriamente dita; $\boldsymbol{a}$, ou pequeno $a$, objeto pulsional causa do desejo, para sempre perdido, perseguido pelo sujeito na tentativa de tamponar a angústia humana da falta-a-ser. É o a que aponta os interesses do sujeito, as questões de valor para ele implicadas, segundo Maurano (2007), objeto que causa nosso desejo, abordado ainda por Lacan como objeto que promete um gozo a mais, um "a-mais-de-gozar" que perseguimos, dado a insuficiência do gozo que se nos apresenta como impossível; e $\$$, ou sujeito barrado, cindido pela radicalidade do inconsciente a impedi-lo de saber-se e falar-se por completo, de ter controle sobre o aparelho psíquico, de viver a plenitude instintiva do ser animal, impondo-lhe a condição humana de ser desnaturado; indica ainda, segundo Maurano (2007), que não há sujeito autônomo, pleno, sendo a fala que nele se tece o que vem em suplência ao que lhe falta para viver em meio à Torre de Babel.

O que produz um sujeito, isto é, não, em geral, um homem ou um indivíduo, mas um ser dependente da linguagem, é que um significante o vai representar junto a todos os outros significantes, e, por isso mesmo, determiná-lo. Porém, a partir disso, há um resto. De fato, desde que se inscreve na linguagem, o sujeito não tem mais acesso direto ao objeto. Ele entra na dependência da demanda, e, quanto ao seu desejo, este só pode ser dito entre as linhas. Disso decorre o conceito de objeto $a$, que Lacan elabora e que designa não o objeto supostamente disponível da necessidade, da consumação ou da troca, mas um objeto radicalmente perdido (Roland Chemama, in CHEMAMA ; VANDERMERSCH, 2007, p. 103).

No Seminário 20: Mais, ainda (1972-1973), Lacan explica que os vetores presentes no matemas enlaçam os elementos dois a dois, enquanto a direção das setas aponta o sentido da determinação entre eles: a verdade determina o agente na função de semblante; agente/semblante determina o outro na função gozo (fálico); outro/gozo determina o produto na função mais-de-gozar; produto/mais-de-gozar determina o agente na função de semblante; 
e, enfim, verdade que determina tanto o agente na função semblante, quanto o outro na função gozo.

O discurso se funda sobre as leis da linguagem e a relação com a fala induz lugares que inscrevem em ocos os termos oriundos dessas leis. A partir do momento em que uma fala se exprime, ela organiza um universo tal que se engendra uma relação fixa de quatro lugares: aquele que fala (agente) e aquele que recebe a fala (outro), o efeito produzido (produto ou mais-de-gozar) e o quarto é o da verdade que articula a relação dos três primeiros termos. $\mathrm{O}$ conjunto forma o núcleo sobre o qual repousa o sistema simbólico: “(...) é claro que a Fala só começa com a passagem do fingimento para a ordem do significante, e que o significante exige um outro lugar, o lugar do Outro, o Outro-testemunha, a testemunha Outra que não é nenhum dos parceiros - para que a Fala que ele suporta possa mentir, isto é, se propor como verdade (Écrits: Subversion du sujet et dialectique du sésir)" (KAUFMANN, 1996, p. 462).

Importante observar que Lacan deixa sem vetorizar a posição do produto/ mais-degozar na determinação da posição da verdade, mantendo esta indeterminada.

(...) "La verdad que se há comenzado a entrever solamente con el discurso analítico... es lo que llamo $\phi x$...", por lo cual esta vigência de la verdad implica necesariamente una nueva restricción en el juego de vectores: hay que suprimir el vector de abajo, el que conectaria el lugar del plus-de-goce con el lugar de la verdad. Esa conexión es imposible, la verdad no puede recibir ningún tipo de determinaciones de ningún outro lugar del discurso. Que en el lugar de la verdad Lacan inscriba al falo simbólico $\phi x$ quiere decir que há culminado la operación de castración del tetraedro. Esta figura, cuerpo platônico por excelência y sostén de cualquier idea sobre el espacio que se pretenda (...), esta figura perfecta resulta conservada en cuanto número cuatro, pero profundamente alterada (castrada, dijimos) en cuanto a todas las operaciones vectoriales que podrían suponer simetria y reciprocidad. Esa armonía funcional, central en la idea platônica, es gravemente subvertida por la teoria psicanalítica (ALEMAN ; LARRIERA, 1998, p. 164).

Caso a verdade estivesse determinada por qualquer elemento, deixaria de ser a mola propulsora do discurso do agente, este que por estrutura se assenta sobre a barra do recalque. Fisgado pela linguagem, do infans cindido faz-se o sujeito da palavra, que pensa onde não é, porém é onde não pensa pensar, já que a estrutura da linguagem funciona pela lógica não racional da hiância ${ }^{83}$ significante, em conformidade ao que o avesso da psicanálise ensina: pelo que falha no discurso, pelos restos precipitados da enunciação, escorre e escapa a verdade inconsciente do desejo recalcado.

De acordo com Chemama, quando o significante é concebido como autônomo em relação à significação, ou seja, quando se reconhece que a palavra, além de nomear um

\footnotetext{
${ }^{83}$ Hiância, termo que não aparece nos dicionários. Substantivo derivado de hiato, remete à ideia de intervalo, de falha, de descontinuidade.
} 
referente, possa se referir a outras coisas, assume uma função completamente diferente da significação, porque irá representar o sujeito e mais, ainda, determiná-lo. Essa é a verdade da psicanálise, como explicava Melman à plateia. O jogo de palavras é dado pelo fato de aquilo que representa não ser o referente da palavra, mas precisamente uma sequência acústica que pode assumir diferentes sentidos. Falar, assim, deixa a estrita função comunicativa para ampliar-se à noção de transmissão.

(...) tais significantes, que se associam e se repetem sem qualquer controle do eu, que se ordenam em cadeias determinadas com rigor, da mesma forma como a gramática determina a ordem da frase, revelam-se, ao mesmo tempo, totalmente constrangedores para o sujeito humano. No caso, a questão do significante remete à da repetição: retorno regular de expressões, de sequências fonéticas, de simples letras que escandem a vida do sujeito, prontas a mudar de sentido a cada vez que ocorrem, que insistem sem qualquer significação definida (Roland Chemama, in: CHEMAMA; VANDERMERSCH, 2007, p. 347-8).

Para Lacan, a "verdade de um discurso corresponde ao ponto de incompletude do discurso em relação a ele mesmo. Ou seja, a verdade de um discurso é o impossível que ele não consegue dominar, não é conteúdo, mas lugar por definição vazio" (DUNKER, 2005).

Caso fosse determinada por qualquer elemento, a verdade seria a dele, como acontece no Discurso do Capitalista, o quinto discurso do ensino de Lacan que perverte a lógica de funcionamento dos outros quatro, atuando contra o liame social, precipitando segregação e isolamento. Nele, a determinação do agente se faz no sentido contrário, invertendo o sentido da seta do agente para a verdade, passando assim a determiná-la, foracluindo a barra do recalque, a castração. A verdade do Discurso do Capitalista não é outra, enfim, que a relação entre sujeito ao objeto.

2 de junho de 1887.

Estamos muito preocupados com Helen: ela anda muito nervosa, sem apetite, e não dorme à noite. O médico acha que seu cérebro trabalha demais. Que fazer para impedi-la de pensar? Ela fala com as mãos da manhã à noite. Se evito conversar, fica escrevendo na mão esquerda, mostrando vivo interesse nessa conversa consigo mesma. (...) Supunha que Helen não tivesse ideia alguma do que fosse uma carta. Ela tem-me acompanhado ao correio, mas pensei que não entendesse o que eu ia fazer. Um dia, porém, trouxe-me uma tira toda cheia de letras e, procurando metê-la num envelope, disse: "Carta para Frank". (...) Aqui vai uma confissão em segredo para você: estou certa de que a educação de Helen irá muito além da de Laura Bridgman. Vejo em minha discípula uma notável capacidade, que conto poder aproveitar. Não sei porque, mas tenho disso plena convicção. Não compreendo, mas, quando surgem dificuldades, resolvo-as prontamente. Parece que adivinho seus pensamentos. Helen está despertando a atenção de todos os que a vêem, como uma criança bem fora do comum. Contudo, é necessário muitíssimo cuidado com o que se tem dito a respeito dela. De minha parte continuarei a escrever a 
você, expondo francamente o que faço e o que penso, mas com a condição de você não mostrar minhas cartas a ninguém. Enquanto eu puder, minha querida Helen não servirá para os noticiários escandalosos (Anne Sullivan, in KELLER, 2001, p. 205-6, negrito nosso).

Que assento é esse que nos convida não ao estudo de caso, mas ao contorno do dispositivo discursivo da mestra no advento dessa educação? Sullivan certamente endereçava-se em posição diferenciada tanto daquela que adotava os Keller, quanto desta em que se encontra embalada boa parte dos educadores brasileiros na atualidade. Vejamos.

Segundo Dunker (2005), não se pode tomar para si um discurso, como agente, sem que se esteja assujeitado por uma dada ideologia de produção de sujeitos. "Inversamente, ser sujeito é o mesmo que ser capaz de reproduzir e assujeitar-se a um discurso", visto que o discurso como rede sócio-simbólica pré-existe em relação aos seres que dele se apropriam. Ao falar, o sujeito agente na função de semblante, necessariamente, toma a posição de acordo com o elemento que dá a forma do seu discurso sobre o outro, este sobre o qual goza ao visar produzir algo, motivo pelo qual discursou. Na narrativa, segundo o autor, o agente pode ser um personagem, um ator, ou um autor, posições que correspondem a níveis distintos de apropriação do discurso. Quando dos escritos de Sullivan apreendemos determinado registro discursivo marcado por uma autenticidade que lhe confere valor de verdade e função de autoria - radicalmente distinta da matriz científica dos relatórios de Jean Itard ao Estado francês sobre Victor de Aveyron -, perguntamo-nos de que lugar aquela mulher professava isto que atribuímos o estilo de seu discurso pedagógico; a quem o endereçava; o que produzia; assentada em quê?

Mal ela enviou a Perkins a descrição de seus primeiros resultados, os jornais de Boston publicaram notícias exageradas sobre Helen. Em carta a uma amiga, logo no primeiro período de trabalhos com Helen, assim se expressa a Srta. Sullivan: "Um jornal em Boston publicou um artigo tolo acerca de Helen. É absurdo dizer que a menina já está falando corretamente. Folgo bastante em ignorar a série de parvoíces que se está escrevendo sobre meu trabalho com Helen. Os resultados que obtenho ainda não convêm ao noticiário berrante dos jornais. Assim, eles enfeitam o que escrevem com as mais grosseiras fantasias. Um deles disse, outro dia, que Helen já está demonstrando problemas de geometria. Qualquer dia, um deles dirá que ela está escrevendo um tratado sobre a origem do mundo" (John Macy, in KELLER, 2001, p. 188).

Pelas cartas de Anne, mais de uma vez, é possível perceber a irritação que lhe causava o assédio da imprensa e a tentativa de fazer da menina uma atração. Em relação aos desdobramentos com Victor, o mesmo não pode ser dito. Nos primeiros dias após sua 
captura, foi exposto à visitação pelos moradores da região. Em seguida, quando o Estado francês tomou para si incumbir-se dele, aí sim o menino se torna, literalmente, um objeto de pesquisa para um pool de cientistas. Nada parecido aconteceu com a menina Keller. Anne falava mais com a menina, do que sobre a menina, nisto que extrapola a mera diferença preposicional, como aponta Lajonquière em seu último livro (2010, p. 215-217). Falar com alguém implica implicar-se nos possíveis tropeços do discurso inconsciente, falar sobre, não.

Segundo Maurano (2007), os discursos propostos por Lacan são expressões da forma como o sujeito se relaciona tanto com os significantes - marcas não apenas sonoras, por onde se fareja o sentido das coisas - , quanto com o objeto. "Assim, o discurso está ligado aos interesses do sujeito, o que é revelado pela sua maneira de conjugar basicamente os quatro elementos do discurso".

A teoria dos quatro discursos introduzida por Lacan é uma extensão da articulação entre inconsciente e linguagem, produzida no início de seu ensino, para o campo dos liames sociais. Assim como Lacan demonstrou, em seu fecundo retorno a Freud, que o sujeito do inconsciente, revelado pela psicanálise, é feito de significante e de sua lógica, o liame social se constitui igualmente na linguagem e obedece a suas leis (COUTINHO JORGE, 2003, p. 40).

Safatle (2007, p. 41) faz lembrar que Lacan, a partir de 1953, ao integrar o conceito de inconsciente a sua teoria de causalidade psíquica descrita até então através da relação do sujeito com imagens ordenadoras de processos de socialização, o faz de maneira muito particular: "A partir de agora, Lacan retornará ao conceito freudiano fundamental. Um retorno bem peculiar, já que esse inconsciente não virá de Freud. Ele virá do estruturalismo.” Dessa forma, afirma o autor, Lacan livra-se de uma noção psicológica de inconsciente ligado a fatos psicológicos como a memória, a atenção, a sensação ou a intencionalidade e o inconsciente passa a ser compreendido como um sistema de regras, normas e leis socialmente partilhadas. Quando Lacan resume "o inconsciente é estruturado como linguagem", demonstra ser a linguagem quem ordena e organiza previamente o campo de toda experiência possível, de forma que também determina tanto o agir, quanto o pensar do sujeito.

Tudo se passa como se as relações com o outro, nossas ações ordinárias, escondessem as mediações das estruturas sociolinguísticas que determinam a conduta e os processos de produção de sentido. Tal ilusão nos faria esquecer como temos relações com a estrutura antes de termos relações com outros indivíduos. Como se a verdadeira relação subjetiva fosse entre o sujeito e a estrutura, e não entre o sujeito e os outros. Daí porque Lacan distinguirá as "relações autenticamente intersubjetivas" (que ocorrem na confrontação entre 
sujeito e estrutura) e a intersubjetividade imaginária, própria à relação entre o sujeito e o outro (SAFATLE, 2007, p. 43-4).

- A mediação simbólica legitimada pelo paradigma comunicativo não promove exatamente isso, intersubjetividade imaginária?...

Assim, transpassado pela linguagem, por meio dos deslocamentos da cadeia significante, o sujeito se constitui imerso no estofo simbólico e imaginário do Outro, em meio à papa real, transmutando em acessibilidades simbólicas e imaginárias a realidade real do mundo, significando, dando nomes, qualificando, circunstanciando, fazendo bordas onde existe nada, vazio.

- Circular o toro ${ }^{84}$, fazer circular a palavra em torno do real, da instância da letra... este um dispositivo discursivo educ(a)tivo da clínica do aprender...

Por meio da linguagem e da discursividade, o sujeito segue na vida girando em torno do que lhe escapa, tentando acertar as contas com a inexequibilidade em ser todo, a falta-aser que o angustia e o locomove.

Através da linguagem há a tentativa de dar conta do impossível que marca o humano; falar é gozar, diz Lacan, referindo o quanto há de tamponamento da falta no uso da linguagem. Nesta referida busca, a teoria lacaniana descreve quatro modalidades por meio das quais se tenta fazer algo com este impossível, com o saber em última instância E é sobre a posição que os sujeitos tomam em relação a este saber que estes discursos são articulados (ZILIOTTO, 2004).

Da renúncia resultante do corte da castração, impedido de desfrutar o prazer de certos objetos investidos de muito valor, o que era infans passa à palavra e torna-se tecível para o laço social: advém como sujeito. Desta feita, tanto estrutura inconsciente do sujeito, quanto as relações humanas do liame social ordenam-se e são essencialmente fundadas pelo mesmo denominador comum: a lógica da linguagem.

- Função princeps do educador... falar com o educando...

\footnotetext{
${ }^{84}$ Toro: "A topologia combinatória é um ramo da matemática que teve origem em Desargues e Leibniz e se desenvolveu com Moebius, Félix Klein e Henri Poincaré. Bourbaki fez dela o terceiro ramo da matemática "no limite do campo matemático". Lacan tomou dessa topologia diferentes superfícies - banda de Moebius, toro, cross-cap, garrafa de Klein - pra explicitar certo número de termos centrais da experiência psicanalítica - desejo, demanda, objeto $a$, falo, identificação, e mais tarde, transferência e, é claro, repetição e pulsão de morte. Tratavase de construir uma estética diversa da de Kant que teria, segundo Lacan, permanecido na falsa evidência da geometria euclidiana e, paralelamente, de elaborar uma nova lógica, que fosse fundamentalmente uma lógica da falta. (...) O toro é uma superfície sem borda, superfície fechada de uma única face, engendrada pela rotação de um círculo gerador. (...) O toro comporta dois vazios, o vazio central e o vazio "interior", ou gerador, que permite traçar dois tipos de trajeto irredutíveis (ao contrário do que ocorreria com uma esfera ou um plano infinito, eles não são redutíveis a um ponto, não são nulificáveis). Um deles, rodeia o círculo gerador, o outro, rodeia o vazio central [como uma boia circular de criança]'(KAUFMANN, 1996, p. 528-529, acréscimo nosso).
} 


\subsubsection{O discurso do mestre, discurso inconsciente}

Em $O$ avesso da psicanálise, ao introduzir o ensino dos "esqueminhas quadrípodes giratórios, (...) esse aparelho de quatro patas, com quatro posições, [que] pode servir para definir quatro discursos radicais" (1991, p. 19), Lacan afirma, por razões históricas, que devia começar pelo discurso do mestre, o que em nosso caso vem a calhar, porque remete à discursividade que poderia ser atribuida em grande parte ao endereçamento de Sullivan aos Keller, mas especificamente a Helen.

O primeiro laço social é instaurado por um mestre: não por um mestre de escola, mas por aquele ou aquela que tem autoridade, isto é, que enuncia um significante-mestre no imperativo, de modo que o outro se ponha em marcha. É a primeira experiência humana uma vez que nascemos crianças e não adultos. A mãe, o pai e muitos outros em posição de agente instauram um laço dominante-dominado através da linguagem. Assim, certos significantes fundamentais constituem o inconsciente do outro, na medida mesma em que a linguagem e não o instinto é a condição do inconsciente. A palavra de ordem, o comando no imperativo faz andar o corpo da criança, do adolescente, do adulto. (...) o "faça isto!" é recebido completado do “...para ser isto!”. É esta a identificação segundo a sequência dos S1: identificação a tal einziger Zug, diz Freud, traço unário do Ichideal: educação, modelização, colonização, transmissão de geração em geração, de acordo com um ideal de domínio sobre si mesmo e sobre o outro (é a mesma!) (JULIEN, 2004, p. 184-185).

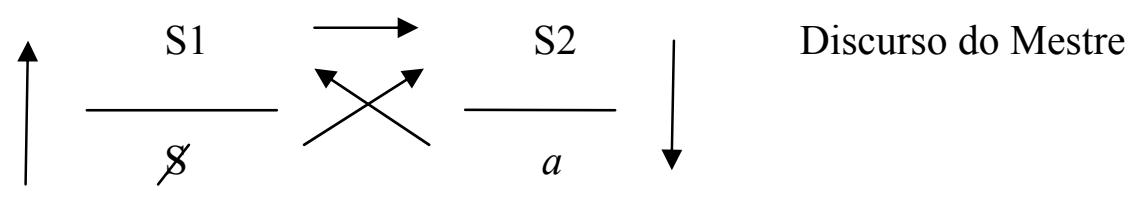

No discurso do mestre, na posição do sujeito agente, encontra-se S1, significante mestre que opera sobre o outro, fazendo funcionar o registro avesso ao da psicanálise ${ }^{85}$. Na posição de mestre, o sujeito fala como se tivesse a certeza de quem sabe sobre o outro, embora tenha sob a barra do recalque o inconsciente na posição da verdade, ou seja, o malestar inquieto do sujeito castrado.

\footnotetext{
85 "Para a psicanálise o sujeito está implicado em todo ato que diz respeito a si, embora aqueles que a consultem nem sempre saibam disso. Por esse motivo e desde o início, a análise visa criar condições para o sujeito se interrogar sobre as causas dos episódios que o incomodam. Entregando-se à elaboração de uma teoria sobre seus sintomas, é ele quem deve reconstruir - e não o analista - um saber ainda não sabido sobre o processo de determinação singular dos acontecimentos "pessoais", ainda que tal saber guarde todo seu poder de efeitos subjetivos enquanto estiver sendo operado por aquele que o produz, ou seja, o próprio analisante, pois na mão de terceiros, revela-se ineficaz" (cf. LAJONQUIÈRE, 1996, p. 28). Esse seria o avesso proposto pela psicanálise, ou seja, não ditar a verdade, porque não a tem. Se alguém a carrega, é o analisante, único a poder tentar dizê-la.
} 
Quando aquele que fala toma a posição de S1, a verdade meio-dita ${ }^{86}$ do agente, pretensamente um enunciado - em verdade-(re)velada: enunciação -, transparece como verdade absoluta a qual, além de saber sobre o Outro, pode indicar o caminho para se produzir, ou encontrar o objeto perdido para mais gozar. Ainda que o dito do mestre esteja ancorado nas próprias experiências subjetivas de um sujeito recalcado, é ele quem enuncia, como senhor, uma ordem: o mestre não pede, manda. $\mathrm{O}$ imperativo que impõe com todo seu poder de persuasão e convencimento o desejo do mestre ao outro, embora surja da verdade recalcada do sujeito, visa nada menos que submissão e obediência do outro objetalizado.

Há de fato uma pergunta a ser feita. O senhor que opera essa operação de deslocamento, de transferência bancária, do saber do escravo, será que ele tem vontade de saber? (...) Um verdadeiro senhor não deseja saber absolutamente nada - ele deseja que as coisas andem. E por que haveria ele de querer saber? Há coisas mais divertidas. Como terá chegado o filósofo a inspirar o desejo de saber ao senhor? (LACAN, 1991, p. 22-23).

11 de março de 1887.

Estou morando sozinha com Helen, numa casa pequenina de campo, de propriedade da família. Sempre achei que não poderia fazer nada com minha discípula em companhia de sua gente, que a deixa fazer tudo o que quer. Ela se habituou a trazer todo mundo sujeito a sua vontade: pai, mãe e os negrinhos $^{87}$ (sic) que brincam com ela. Qualquer desejo seu contrariado resulta numa tremenda gritaria e má-criação, difícil de conter. Helen não cedia um só ponto a minha vontade. Para fazê-la pentear o cabelo, lavar as mãos ou abotoar os sapatos, eu tinha sempre que empregar força e brigar com ela. A família inteira acudia pressurosa, especialmente seu pai, que não podia vê-la chorar. Preferiam ceder aos caprichos dela para deixá-la em paz, mostrando-se contrários a minha insistência em obter que a menina me obedecesse. Sem essa obediência eu não poderia ensinar-lhe coisa alguma. Como já lhe disse, pensei que pudesse ir aos poucos conquistando a amizade de minha discípula, como se faz com as crianças que ouvem e vêem. Compreendo agora, porém, que ela não sente a minha simpatia. Aceita como obrigação o que lhe faço e recusa-se a receber minhas carícias. Parece impossível despertar nela a ternura e a afeição de criança. Eis, minha boa

\footnotetext{
${ }^{86}$ Para Lacan, a verdade nunca será dita por completo, será sempre semi-dita, porque barrada pela linguagem e pelo saber-não-sabido do inconsciente, relembra Alberti (2000) a respeito da verdade do sintoma - verdade sempre velada, embora seja ela, no fundo, o que sustenta não apenas o sintoma, mas também o discurso, ainda que através do semblante - exceto no discurso do analista - pois "o discurso impõe a necessidade ao homem de a ele se submeter pelo semblante, faz-de-conta que tem valor de verdade". Segundo Maurano (2007), como a verdade passa pela linguagem e a linguagem tem uma estrutura de ficção, por conseguinte, aquela só pode ser semi-dita, porque essa é a lei interna de toda enunciação sobre a verdade e é o que faz com que, no final das contas, a "besteirada" e a verdade sejam idênticas (sic).

${ }^{87}$ Embora a abolição da escravidão no EUA tenha ocorrido em 1863, o preconceito racial de Sullivan nesta passagem fica estampado.
} 
amiga, para o que a gente estuda e se forma. No momento de aplicar as teorias, tudo falha. Temos é de confiar nessas capacidades inatas que só descobrimos em nós quando chega a hora de pô-las em ação (Anne Sullivan, in KELLER, 2001, p. 194-5).

- Música atonal para os ouvidos! No momento de aplicar as teorias, tudo falha, diz a mestra!, Ió! Ió! Baco, Ióóóó!..Evoé!!!

Anne Sullivan, sem dúvida, desejava que as coisas "andassem" e, nesse aspecto, posicionava-se com virilidade, discursando a partir do lugar de mestre, pondo sua discípula a trabalhar em nome de um desejo possivelmente enlaçado aos fantasmas de seu romance familiar americano-irlandês. Não raro, encontramos em seus escritos passagens que descrevem as ações educativas nas quais atos aconteciam. No filme, cenas são construídas para ilustrar como a educadora, a todo custo, procurava sustentar sua posição utilizando estratégias diversas. Ora teimava em ensinar o alfabeto à menina que se punha a fugir; ora tinha que se esquivar das reações físicas violentas de Helen; ora dava explicações aos familiares sobre o porquê de seus procedimentos. E nem por isso, sozinha em seu quarto, à noite, com seus cadernos, cartas e pesadelos, não se deixava perder em pensamentos de insegurança, pedidos de ajuda a Deus, choros, principalmente após momentos críticos de embate e impasse. Nisso, também, apontamos o registro do mestre, que endereça ordens e certezas, mas na verdade, mantém-se ouvindo os ecos de um sujeito cindido, faltoso, assentado sob o recalque. Esse era um dos assentos discursivos de Anne Sullivan, que à diferença de Itard, não se reconhecia como toda. Anne girava nos discursos, pois dava-se a liberdade de, nem sempre, professar enquanto mestre... mulher de idiossincrasias ... estamos tentando demonstrar.

22 de maio de 1887.

Helen é uma criatura tão original e tão desejosa de aprender que meu trabalho se torna cada vez mais interessante. Apesar de ainda não fazer três meses que aprendeu a primeira palavra, ela já sabe mais de trezentas, além de muitas frases correntes. Que grande privilégio o meu, ver desabrochar e fortalecer-se o espírito dessa criança invulgar! Sinto-me já impotente para a tarefa. Tenho a cabeça cheia de planos, mas não sei pô-los em ordem. Se alguém pudesse ajudar-me! Preciso de professor, quase tanto quanto Helen. Estou certa de que a educação de tal menina será o orgulho de minha vida, caso eu tenha forças para levá-la adiante. Preciso ensinar Helen a fazer uso dos livros: você poderia arranjar-me a Psicologia de Perez e a de Sully com o Sr. Anagnos? (Anne Sullivan, in KELLER, 2001, p. 204).

Assim, o discurso do mestre estabelece laço social entre aquele que manda e aquele que trabalha ao articular o desejo do agente ao desejo do outro (escravo/aluno), vida e morte, 
trabalho e casa, objeto e gozo, ainda que o saber transformador - que é o trabalho - esteja do lado do outro objetalizado, sutileza que faz a diferença.

O discurso do mestre é o laço civilizador que exige a renúncia pulsional, promovendo rechaço do gozo que retorna sob a forma do supereu, do qual o sentimento de culpa do sujeito é o índice que se manifesta através do olhar que vigia e da voz que critica. O discurso do mestre produz os dejetos da civilização - o que escapa à simbolização - sob a forma de mais-de-gozar (QUINET, 2001).

Contra-mão ao discurso do capitalista, o discurso do mestre, mesmo se autoritário, não é sem Lei, nem trabalha a favor da foraclusão da castração, muito pelo contrário, nos dá mostras dela: não fosse o escravo, o mestre desapareceria, perderia a razão de ser, ou melhor, perderia a mestria, já que do trabalho do escravo depende o mestre, escancarando que este não é mesmo todo. Que o discurso do mestre seja regulador, não resta dúvida, porém segregador de jeito algum, função ocupada pelo capitalista. Seria o discurso do mestre, então, o que põe a andar uma educação na palavra plena do educador? Parece-nos que sim... mas não só... não todo...

A partir do discurso do mestre, retroagindo os quatro elementos em um quarto de giro, três vezes, dão-se outros três discursos: da Universidade, do Analista e da Histeria, embora haja ainda o Discurso do Capitalista, este que configura uma mutação perversa do discurso do mestre, cujo funcionamento subverte a ordem da estrutura proposta por Lacan.

\subsection{3 - Discursos universitário, da ciência, da educação}

A partir do primeiro giro anti-horário do discurso do mestre, tem-se o que o autor denomina Discurso da Universidade, no qual o lugar do agente é ocupado por S2 - saber que fala em nome da cadeia de significantes - em direção ao outro objetalizado, não mais persuasível ou sugestionável, mas tomado como sujeito pensante, de preferência em conformidade ao conhecimento do agente que discursa, este representante da cultura estabelecida a quem o educando deve se sujeitar, alienando-se ao discurso proferido, reiterando o que é professado:

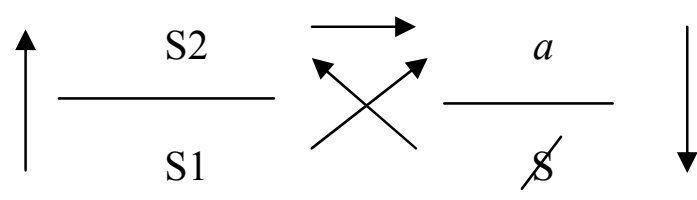

Discurso da Universidade 
Nesta forma discursiva, o significante mestre S1 posicionado no lugar da verdade, passa a ter valor de mandato. S1 é deposto da posição de agente barrado sustentado pela verdade do $\$$, como era no discurso do mestre, para assumir o lugar da verdade dos enunciados legitimados pelo saber acadêmico. Por conseguinte, no discurso da universidade teorizado por Lacan, não sobraria lugar para o sujeito da enunciação, já que o que resta como posição de produção do mais-de-gozar é a iteração, como determina a seta que vai de $\not$ a S2. Em nome da ciência e dos conhecimentos aferidos por ela, o que é imposto aos alunos é que renunciem sua palavra, precisamente a enunciação de sujeito cindido, para que aprendam e respondam tanto às normas, como aos programas e saberes validados pela comunidade universitária, a fim de produzirem mais e mais conhecimento.

O discurso do mestre moderno é o discurso universitário: o mestre foi substituído pelo saber universal científico. Consequência: tirania do saber, que exige, a qualquer custo, a obediência ao mandamento do saber, a ordem que se apresenta como a verdade da ciência. Essa ordem pode ser assim formulada: "Tudo pelo saber!" ou "Saiba tudo sobre tudo, sem nada deixar escapar". Podemos continuar a formulação do imperativo epistemológico: "Não importa o que aconteça, continue avançando; continue trabalhando para o saber". "Não importa os meios nem os fins - não deixe de produzir saber". Eis a representação que ordena a fala implícita na conquista da ciência; ele é o significante-mestre que ocupa todo o lugar da verdade no discurso universitário - a verdade do sujeito - é rejeitada em prol do mandamento de tudo saber. O mestre da ciência universitária é o saber e nada pode detê-la como o tentam os comitês de ética criados para nela colocar uma barreira, um freio, uma regulação (QUINET, 2002, p. 20).

No entanto, fazemos notar, no lugar da produção dessa forma de discurso, ou seja, no lugar de mais-de-gozar, encontra-se de qualquer maneira o sujeito barrado que, apesar de sofrer o mandato da reiteração do saber estabelecido, continua falante, portanto desejoso, escorregadio, incontrolável, imprevisível, isso que remete, tanto na universidade, quanto nas escolas da educação básica, às aprendizagens e produções acadêmicas "tortas", primas mesmas do que trabalhamos na Clínica do Aprender ${ }^{88}$. Nesse ponto, convém lembrarmos a observação de Kupfer (2000) sobre o trabalho do professor:

Ele deve ser capaz, para usar a metáfora de Freud, de ensinar o catecismo a selvagens, acreditando no que faz, com paixão mesmo, sem desconhecer que seus selvagens, às escondidas (vale dizer, nos domínios do inconsciente), continuarão adorando seus deuses antigos. Ou seja, [seus alunos] manterão a fidelidade a modos de pensar subjetivos. Ouvirão o que lhes ensinam de acordo como seus desejos, seus recortes particulares. Ouvirão o que thes convier e jogarão fora o resto, sem que isso implique uma rebeldia consciente,

\footnotetext{
${ }^{88}$ Termo cunhado por Lajonquière para o trabalho que se volta aos impasses do aprender escolar.
} 
uma manifestação perversa ou delinquente [ou ainda deficitária] (...) O [des] encontro entre o que foi ensinado e a subjetividade de cada um é que torna possível o pensamento renovado, a criação, a geração de novos conhecimentos. Esse mundo desejante, que habita diferentemente cada um de nós, (...) estará preservado cada vez que um professor se dispuser a desocupar o lugar de poder em que um aluno o coloca necessariamente no início de uma relação pedagógica, (...) saberá que estão em jogo forças que ele não conhece em profundidade, mas que são muito importantes para a superação do professor como figura de autoridade e indispensáveis para o surgimento do aluno como ser pensante (KUPFER, 2000, p. 98-99, acréscimos nosso).

De fato, embora escola e universidade sejam lugares para postar alunos à sujeição de conhecimentos já estabelecidos pela cultura, sem dúvida são lugares que promovem conflito cognitivo, de forma que o sujeito, em posição de aluno, sempre está exposto à dúvida, ao mal-entendido, à sensação de ignorância, de descrédito, senão de estranhamento - dinâmicas capazes de fazer suas representações psíquicas girar em torno do ainda incompreensível, quando não do inaceitável enquanto enunciado final e fechado. Lugares de reiteração, sim, embora não apenas, já que aprender, ensinar e estudar produz efeitos inesperados para além do que é planejado, pedagogicamente ou não, seja na escola, ou na universidade.

Assim, concordamos com a autora:

(...) nem tudo que ocorre na Universidade é discurso universitário. (...) Nós que tramitamos no circuito acadêmico e que tentamos elaborar teses na Universidade, sabemos o quanto nos custa querermos, não propriamente apresentar uma verdade a ser defendida, mas sim dizer algo de estruturalmente rigoroso. Dar aulas comprometendo-se com a parcialidade da verdade, com sua estrutura de ficção, implica na transmissão de um saber sem saber, ou seja, na transmissão de um enigma. Um enigma é um dizer pela metade. É um dizer fisgado pela verdade, mas que não elide o abismo que há entre esta e o saber (MAURANO, 2007, negrito nosso).

Talvez possamos considerar dois discursos distintos: o universitário cientificista bancário, posto a serviço do poder econômico, político e religioso (cf. JULIEN, 2002, p.186); e o da Universidade, este que talvez possamos entender como Discurso da Ciência. "A fórmula do discurso universitário (ou discurso "da" universidade) intervém no Seminário 17 em contraponto ao discurso da ciência, na medida em que supostamente manifesta aquilo de que este último se certifica" (KAUFMANN, 1996, p. 562). Pois se a elaboração teórica dos enunciados encontram a verdade na dor de existir, como vimos com Melman, talvez Quinet (2002) tenha razão ao afirmar que "o que se espera da ciência é efetivamente a produção de saber sobre o real".

Assim, ainda que o discurso da ciência esteja alicerçado, até certo ponto, no discurso universitário, não se confunde com ele, como afirma Maurano. Ao discurso científico, 
reserva-se na universidade um lugar especial, embora não possamos dizer que tudo produzido ali seja efetivado como Ciência.

Miller ressalta que na Universidade se ensina em nome de um saber que não é forçosamente ciência, mas está a ela ligado por uma coerência, e por relações que comportam uma certa estabilidade. Nessa perspectiva, o discurso da ciência é tomado como o que elide toda a potência dinâmica, o problema é que aí, facilmente, se cai na tautologia e elimina-se todo o dinamismo do trabalho da verdade. O discurso analítico vem questionar, então, para que serve um discurso que exclui o dinamismo da verdade (MAURANO, 2007).

Por conseguinte, se o que determina a verdade recalcada do discurso da universidade é o significante mestre, longe estará o discurso da ciência da neutralidade que tanto pretende almejar. "Sendo ele o significante que tem por função promover o laço social, por sua própria referência ao social, revela também o compromisso com o que o sustenta, e que vem, portanto, agir como motivação da produção do saber científico." (Idem). Que o \$\$ na posição de mais-de-gozar não determine a verdade desse discurso - esse que é o furo do discurso universitário -, não nos impede de pensar que, ali posicionado, o educando escreva e responda, parcialmente e durante certo tempo, da forma que lhe ordenam fazê-lo, segundo exigências procedimentais universitárias ou escolares. Mesmo assim, nas entranhas de suas representações mais recônditas, como acentuou Kupfer, nada impede que o aluno mantenha a brasa incandescente do desassossego de suas buscas, ainda que em enunciação barrada. Isso, talvez, possamos reconhecer como semblante de aluno... Pois que não tenha alcançado ainda a legitimidade acadêmica para a livre-enunciação, não significa que não venha obtê-la, quando títulos e créditos conquistados permitirão sua entrada e possível estada entre o grupo de legitimadores do conhecimento que, por um tempo, talvez, também tiveram que encontrar subterfúgios para dar vazão a suas perturbações intelectuais em lugar de apenas reiterar os enunciados já validados. Caso contrário, o que justificaria a tentativa de desdobrar neste longo e disperso movimento escrito a desconstrução discursiva hegemônica em campo pedagógico?

Todavia outro aspecto incomoda: o educar constitui-se como discurso universitário?

Embora os registros discursivos propostos por Lacan possam ser relacionados às atividades que Freud adjetivava como impossíveis - governar, educar e analisar -, supomos impreciso apontar o discurso da educação ou da escola como correlatos ao discurso universitário. Fosse verdade, o processo educativo pouco diferiria de uma espécie de download psíquico, o que não acontece enquanto não nos endereçamos a robôs.

Verifiquemos uma passagem de Quinet sobre esta questão: 
Governar corresponde ao discurso do mestre/senhor em que é o poder que domina; Educar constitui o discurso universitário dominado pelo saber; Analisar corresponde ao laço social inventado no início deste século por Freud em que o analista se apaga como sujeito por ser apenas causa libidinal do processo analítico. E o discurso da histeria é aquele que é dominado pelo sujeito da interrogação (no caso da neurose histérica, trata-se da interrogação sobre o desejo) que faz o mestre não só querer saber, mas produzir saber (QUINET, 2002, p. 32).

Foi o orientador deste trabalho quem chamou nossa atenção, por parecer-lhe inexato afirmar que o discurso da educação esteja em sinonímia ao discurso universitário. Que o dispositivo do discurso universitário possa ser atribuído ao discurso da pedagogia atual, não resta dúvida. Contudo, dizer o mesmo sobre o educar não corresponde, como procurou demonstrar em Infância e Ilusão (Psico)Pedagógica. Vejamos o que podemos acrescentar e o que podemos rememorar.

Quando falamos de educação e de pedagogia, falamos do quê?

O termo Educação circunscreve pelo menos três aspectos: constitui uma área de atuação profissional, um campo de estudos inter e multidisciplinares, além de participar do processo civilizatório e humanizante. Contudo, educar não se restringe à "pedagogizar", uma vez que a humanização não está circunscrita ao locus escolar, de modo que o pedagogo não se configura como único agente. De fato, não só a escola educa, ensina ou transmite marcas de desejo aos mais novos, mas também a família, os amigos, os que vão à rua e todas as instituições por onde circula o Outro. Educar, para muitos, além dos objetivos de instrução, mantém-se na perspectiva da socialização, preparando e modelando o indivíduo para o convívio social:

De Platão a Durkheim, passando por Kant, a escola continua sendo o espaço e o tempo da aquisição dos "bons hábitos", dos quais dependem não só o surgimento de um indivíduo conforme às normas, mas ainda o da "alma coletiva". Compreende-se, então que Durkheim tenha feito esta observação: "Em vez de servir à emancipação do indivíduo, para libertá-lo do meio que o envolve, (a moral) tem como função essencial transformá-lo em parte integrante de um todo e, por conseguinte, retirar-lhe algo da liberdade de seus movimentos" (IMBERT, 2001, p. 22-23).

Nesse sentido, educar seria adaptar o indivíduo à sociedade. Entretanto, vejamos o que Norbert Elias escreve sobre as mônadas e o processo civilizador, isto que também podemos entender como uma das faces da educação:

(...) é necessária uma crítica à moderna imagem do homem para que possamos compreender o processo civilizador. (...) Enquanto encararmos o ser humano individual como um continente fechado, com uma casca externa e um núcleo escondido no seu interior, não poderemos compreender o processo civilizador que se prolonga por várias gerações, no curso das quais a estrutura da 
personalidade do ser humano individual muda sem que mude a natureza dele. (...) Enquanto o conceito de indivíduo estiver ligado à autopercepção do "ego" em uma gaiola fechada, dificilmente poderemos conceber a "sociedade" como outra coisa que um conjunto de mônadas sem janelas. Conceitos como "estrutura social", "processo social", ou "desenvolvimento social" parecem então, na melhor das hipóteses, criações artificiais dos sociólogos, como as construções "ideais típicas" de que os cientistas necessitam para instaurar alguma ordem, pelo menos no pensamento, no que parece, em verdade, ser uma acumulação inteiramente desorganizada e desestruturada de agentes individuais absolutamente independentes. $\mathrm{O}$ real estado das coisas é o exato oposto. (...) A imagem do homem como "personalidade fechada" é substituída aqui pela de "personalidade aberta", que possui maior ou menor grau (mas nunca absoluto ou total) de autonomia face a de outras pessoas e que, na realidade, durante toda a vida é fundamentalmente orientada para outras pessoas e dependente delas (ELIAS, 1994, p. 248-249).

Essa rede de interdependências entre os seres seria o que os liga, formando o nexo do que Elias não denomina adaptação, mas configuração, estrutura de pessoas mutuamente orientadas e dependentes.

Uma vez que as pessoas são mais ou menos dependentes entre si, inicialmente por ação da natureza e mais tarde através da aprendizagem social, da educação, socialização e necessidades recíprocas socialmente geradas, elas existem, poderíamos nos arriscar a dizer, apenas como pluralidades, apenas como configurações (Idem, ibidem, p. 249).

Mais apropriado do que conceber os homens à imagem do indivíduo adaptável à realidade social, seria compreender essa mesma realidade como a configuração surgida da interdependência de numerosas pessoas em grupos ou sociedades de tipos diferentes entre si. Para exemplificar o que seria uma configuração, o autor escolhe as danças de salão, no lugar de imaginarmos Estados, cidades, famílias ou sistemas como o capitalista, o comunista, ou o feudal, embora também pudéssemos.

Tal como as demais configurações sociais, a da dança é relativamente independente dos indivíduos específicos que a formam aqui e agora, mas não dos indivíduos como tais. Seria absurdo dizer que as danças são construções mentais abstraídas de observações de indivíduos considerados separadamente. Da mesma maneira que as pequenas configurações da dança mudam tornando-se ora mais lentas, ora mais rápidas - também assim, gradualmente ou com maior subitaneidade, acontece com as configurações de numerosas unidades sociais (Idem, ibidem, p. 250).

Tal como a matriz educativa encampada por Durkheim tem por objetivo, em última instância, regular a modelagem do homem para a preservação e prorrogação da harmonia do corpo social via definição de regras, ou seja, numa matriz adaptativa, Francis Imbert aponta 
outra vertente para a função do educador, mais voltada para o que Elias denominou como processo civilizador. Segundo Imbert, querendo ou não, o educador há de lidar com as regras, mesmo porque não deixa de ser um representante da lei social, mas principalmente deverá encarnar a Lei que estabelece a diferença entre o homem e o animal, a Lei da proibição do incesto.

Por se encontrar do lado da lei - garantia do humano - , o educador tem a obrigação de descolar-se de qualquer posição que o erigisse em guardião das regras. (...) Por isso a função de educador é realmente transgressora. Em pleno âmago da ordem instituída, de suas salvaguardas, de sua violência e de suas habituais sanções, o educador dá testemunho de Outro engajamento: nem guardião, nem reparador, seu objetivo não consiste em uma instalação de conformidade ou em uma "regularização", na medida em que essas duas funções visam exageradamente o recalque do sujeito. (...) A educação implica em uma transgressão, uma distância, em relação às intenções de modelagem e moralização. No entanto, essa transgressão e essa distância não visam a abolição da lei que acarretaria a supressão das diferenças e a identificação imaginária com o outro; na realidade, ela entranha um pôr em ato a lei (IMBERT, 2001, p. 139).

Assim, o ato educativo em contraposição à socialização adaptativa, equivaleria a tomar as coisas em referência a um Outro e não tratar de repetir o discurso e as práticas das regras instituídas, tampouco refletir as imagens fascinantes de um fora-da-lei, mas garantir "o aberto" necessário à emergência do sujeito, afirma Imbert. A função do educador estaria justamente em sustentar um engajamento ético em oposição tanto às intenções de moralização, quanto aos fascínios imaginários, nisto que talvez possamos indicar ir ao encontro do que Elias denomina configuração de uma construção social:

(...) Para ele [educador], não se trata de denunciar as más formas, os eus (moi) irregulares, tampouco elogiá-los, mas interpelar, para além do eu (moi) e de suas implicações imaginárias, o sujeito portador de uma fala e de um desejo singulares. A educação pressupõe tal engajamento em uma práxis em que cada qual consegue separar-se das definições e designações que trabalham por conta das propriedades do eu; neste caso, a práxis educativa é entendida como processo de inscrição das rupturas que suportam o poder de conduzir-se como sujeito (Idem, ibidem, p. 140, acréscimos nossos).

A distinção ética/moral conduziria, portanto, a uma nova diferença fundamental, precisamente aquela entre regra (a lei-código, a lei institucional) e a lei simbólica. Enquanto a regra é o princípio constitutivo dos "hábitos" e das formalizações de um Eu magistral, a ética opõe à regra (e a seus efeitos imaginários) a eficácia da lei que permite aos homens se separarem, além de se sentirem e viverem diferentes, afirma o autor. Enquanto o desafio da regra é a fabricação-de-imagem, ou ainda a edificação de um Eu cuja função consiste em criar 
ligações e subjugar, o desafio da lei é a ex-sistência do sujeito pela inscrição de uma separação que diferencia, desliga e liberta o sujeito, sendo que a inscrição inaugural dessa lei fundadora do desejo e da palavra é a interdição do incesto que regula a distância do Sujeito à Coisa - das Ding - , espaço ocupado pela mãe (cf. Idem, ibidem, p. 23-24).

Exatamente nos aspectos em que a empreitada de moralização (de educação) continua subsistindo o cordão umbilical por novos vínculos "muito mais sólidos", o projeto ético tem como único objetivo cortar tais vínculos.

Tal corte verifica-se porque o projeto ético reinscreve, no campo das práticas, o reconhecimento da liberdade e singularidade essenciais do sujeito; $\mathrm{e}$, de modo mais preciso, porque às regras que criam ligações e subjugam, ele opõe a eficácia da lei que é de origem das separações, das castrações simbólicas produtoras da palavra e do desejo.

(...) Desde agora, poderíamos estabelecer que, no campo educativo, a interpelação ética entende-se como a atualização da lei, inter-dição de uma fala que, ao mesmo tempo, confessa e interrompe instantaneamente o jogo das pulsões e a fruição imaginária de que se alimenta o par educativo (Idem, ibidem, p. 26-27).

Por outro lado, por Pedagogia é comum que se entenda o conjunto de estudos agrupados e designados como ciências da educação, ainda que certos autores falem em "pedagogia científica" ou em "ciência da educação" (cf. CARVALHO, 2001, p. 28). Segundo José Sérgio Fonseca de Carvalho, o discurso pedagógico estaria estruturado em alicerces de estudos sistematizados sobre os procedimentos de ensino e aprendizagem e também instituições educacionais, em estudos elaborados por cientistas dos mais diversos ramos de investigação, como a sociologia, a psicologia, antropologia, história, economia, entre outras, embora haja predominância das pesquisas em psicologia do desenvolvimento, da aprendizagem e em sociologia da educação. Nos moldes de Durkheim, por ser do intuito pedagógico dirigir a ação educativa, a pedagogia configura-se como uma teoria prática, apresentando-se sob a forma de uma mistura de padrões descritivos, normativos e exortativos, como analisa Carvalho. Para o autor, os discursos pedagógicos parecem ter desenvolvido historicamente a peculiaridade de se apropriar das produções do discurso científico, ainda que a apropriação de resultados da atividade científica faça-se independente dos produtos em relação ao modo específico de sua produção, como por exemplo a transposição de conceitos, visões gerais e perspectivas desvinculadas das especificidades do contexto escolar. Por exemplo:

Falar de um aluno não coincide com falar de um sujeito epistêmico, ainda que possamos classificar e determinar tal aluno dentro dos parâmetros de qualquer psicologia do desenvolvimento, assim como de qualquer teoria econômica ou sociológica. Sua condição de aluno, no entanto, só pode emergir de relações 
institucionais determinadas pelo contexto escolar. Por decorrência, a compreensão dessa condição não é possível em abstração desse contexto (Idem, ibidem, p. 36).

No doutoramento em que se voltou sobre as diferentes configurações assumidas pela pedagogia dita científica, Maria Amélia Santoro Franco (2008) referendou Herbart (1776 1841) como o responsável por qualificar a pedagogia como ciência da educação, inserindo o pensador na seguinte cronologia pinçada por nós: Francis Bacon (1561-1626), Comênio (1592-1670), Descartes (1596-1650), Itard (1774-1838), Maria Montessori (1870-1952). Atentemos: Herbart e Itard contemporâneos! As publicações de Herbart, segundo a autora, são consideradas as primeiras obras científicas da pedagogia, atribuindo à psicologia a base experimental para funcionar como propedêutica à pedagogia, imprimindo-lhe o que seria a orientação ética da educação, no entender daquele autor. Para Franco, por centralizar a proposta científica da pedagogia na instrução, inicia-se com Herbart a redução do educacional ao instrucional, isto que pretendemos, precisamente, estilhaçar ao apontar o registro ortodoxo-obsessivo da pedagogia costumeira.

Que a pedagogia sempre tenha sido uma reflexão mais ou menos sistematizada sobre os fins e os meios da educação não é novidade, mas que na modernidade ela seja sonhada como intervenção passível de se adequar ao desenvolvimento natural da criança, esse é um aporte desenvolvido por Lajonquière há anos, que nos locomove em vagões. Nesse sentido, discurso pedagógico e discurso universitário com certeza encontram sinonímia, uma vez que o discurso psicopedagógico hegemônico se alia à pedagogia ortodoxa das metodologias de ensino para justificar "cientificamente" as prescrições sobre o quê fazer da ação educativa, além de como , quando e por quê, isso que o autor afirma ser o corolário do processo de psicologização da reflexão pedagógica moderna (cf. LAJONQUIÈRE, 1999, p. 25). Por reflexão (psico)pedagógica, esclarece, "entendemos aquela que se estrutura em torno da pergunta sobre a pertinência psicológica do fazer adulto com vistas ao desenvolvimento das potencialidades supostas na criança e no jovem" (Idem, ibidem, p. 31). Todavia, adverte :

(...) se a educação hoje converte-se a priori em um fenômeno de difícil acontecimento, tal coisa se deve ao império do ideário (psico)pedagógico contemporâneo. Nesse contexto, cabe afirmar que a impossibilidade para a qual Freud nos alertou não é, em absoluto, essa mesma. A impossibilidade apontada por Freud é aquela embutida em todo ato educativo para além de toda discussão acerca de sua natureza proporcional. Mais ainda, trata-se de uma impossibilidade de direito embutida em todo ato - educar, analisar e governar - que faz laço ou discurso. Trata-se, de uma impossibilidade que implica estarmos certos de antemão de que "os resultados serão insatisfatórios" (Freud, 1937b, p. 275-287) ou, em outras palavras, que o ponto de chegada não reitera o de partida (Idem, ibidem, p. 26). 
A forma com que o espírito moderno acaba lidando com esse mal-estar, ao invés de apontar para uma articulação fértil da diferença do que se desdobrou através do discurso e que poderia advir como uma sublimação do resto implicado na insatisfação em relação aos resultados, indica Lajonquière, é que, pelo fato do aluno não se encaixar ao enquadre pedagógico, o que acontece em decorrência do rechaço desse resto e da mesma impossibilidade que retorna no real é acabar minando, justamente, o desdobramento do processo educativo que, assim, termina se endereçando a uma massificação crescente do gozo, atentando contra o próprio princípio da educação, ou seja, conduzindo a impasses no processo de subjetivação inerente à função educativa (cf. Idem, ibidem, p. 26).

A cientificidade psicopedagógica autorizada a saber cada vez mais sobre a natureza do educando, põe-se a falar sobre ele, diagnosticando-o, nomeando-lhe o real que insiste em se inscrever quando o sujeito, sempre movido a pulsão, não responde a contento à gama de estímulos e mediações justificadas pelo discurso da cientificidade.

Dessa forma, quem sabe sobre a educação e portanto fala como especialista na matéria é o (psico)pedagogo - suposto hoje detentor de uma série de saberes "psi" aplicados que possibilitam calcular os efeitos psicodesenvolvimentistas das metódicas intervenções "educativas" colocadas em ação (Idem, ibidem, p. 29).

Entretanto, como estamos dizendo...

(...) o interesse em ajustar a intervenção a um suposto estado natural das capacidades dos escolares implica na renúncia ao ato. Isto é, implica na demissão do adulto da posição do educador, pois, em lugar de invocar o impossível de um sonho - como diria Rubem Alves - ou de um desejo, resigna-se a "tocar" a educação do "possível psicológico" (Idem, ibidem, p. 33)

De forma que podemos parear a crítica de Lajonquière a crítica que Elias teceu em relação ao homem tomado como mônada:

Se a pedagogia moderna perde-se na reflexão a ponto de acabar renunciando à educação, tal coisa deriva do fato de se acreditar na tese da individualidade psicológica como resultante do desenvolvimento ajustado de capacidades orgânicas que amadureceriam graças a uma estimulação correta conforme o tempo (Idem, ibidem, p. 32)

E enfim, mais uma aproximação, desta vez com o pedagogo obsessivo ortodoxo.

(...) que afirma uma pedagogia que se preze moderna? Que dizem os manuais para ser um bom pai ou um bom professor vendidos nos shoppings? Afirmam que a intervenção junto à criança tem que ser justificada. Tal coisa quer dizer "cientificamente ajustada" de forma a evitarmos proibições à toa ou fora de lugar (...). Assim, teríamos uma intervenção natural e normal a cada 
momento e, portanto, a obrigação de se pensar duas vezes antes de intervirmos para não correr o risco de que aquilo que poderia ser normal acabe se revelando frustrante por conta desse destempero psicomaturacional (Idem, ibidem, p. 34).

E como vimos anteriormente, o obsessivo ortodoxo não é exatamente aquele que se atém à segurança dos enunciados, das rezas, forcluindo a castração?

$\mathrm{O}$ adulto que age em nome da natureza não o faz em nome do desejo, desse mistério que desponta por trás de toda arbitrariedade, de toda assimetria, de toda falta de relação ou adequação. Em suma, o adulto atua como um servidor obediente aos mandatos naturais que apontam tornar real um ideal de natureza (Idem, ibidem, p. 36).

Entretanto, se vimos com Imbert que a função do educador implica a ética da atualização da lei promotora da palavra e do desejo, obviamente que nem tudo nos campos do educar é discurso universitário, pois uma educação pode se desdobrar com vistas a outra realidade, não a da materialidade física do mundo, mas a do Real do sujeito, isto que Lajonquière pôde nos explicar com preciosidade lapidar, via e-mail em trocas orientandas, que “...a educação efetiva um sujeito como pulsar»"89.

(...) a realidade da qual Freud falava, não era bem a realidade tal qual estamos acostumados a pensar. Se assim fosse, o mote da substituição de um princípio por outro do funcionamento psíquico faria da psicanálise uma psicoterapia adaptativa qualquer. Trata-se, ao contrário, da realidade do desejo que condena o homem a estar sempre meio fora de foco consigo mesmo e, portanto, lançado à impossibilidade de pretender ser também sempre outro (LAJONQUIÈRE, 2010, p. 56-57).

E como levar a cabo tal educação senão desatrelando-se das ilusões tecnocientíficas que recusam a realidade da pulsão e do desejo?

Como educar para a realidade? Para o desejo? Para o reconhecimento do impossível? Enfim, como se educa? Pois, endereçando a palavra a uma criança. Falando? Sim! Como? Como especialista? Não, como simples mortal. Como alguém que reconhece para si que não pode não falar - em certos momentos - aquilo que está falando. Porque nessa precisa palavra, conjugam-se suas esperanças e seus medos. Portanto, se a palavra não fosse (mal)dita, o adulto saltaria por cima de sua castração. A palavra com chances de educar é essa palavra marca da sujeição do adulto à castração. Isto é, essa palavra testemunho do que escapa à ciência do sujeito. (...) Uma das figuras daquilo que escapa ao adulto quando endereça sua fala a uma criança é, justamente, o controle dos efeitos dessa fala. Ou seja, o que escapa é a mesmíssima educação. (...) Portanto, um educador atravessado pela psicanálise ou, se preferirmos, tocado pela experiência freudiana, em algum momento poderá dizer a seco - sem ouropéis pedagógicos: Vá! Aí o sujeito

\footnotetext{
${ }^{89} \mathrm{Em} 21 / \mathrm{Nov} / 2010$.
} 
tem chances de advir. Mas não há garantias, pois nesse instante, a máxima faustina - " deves adquirir aquilo que herdas" - , que Freud gostava de lembrar de Goethe, entra em cena mostrando todo seu valor... todo seu valor educativo (Idem, ibidem, p. 66-67).

Logo, se o discurso universitário segue seu recurso em linha reta, com vistas à produção de sempre cada vez mais e mais saber, seja sobre o aluno objetalizado, seja sobre qualquer outro objeto investigativo, enquanto por outro lado, o discurso capitalista segue em looping, o discurso de uma educação funciona em giro. Quiçá também em movimento pendular, como estamos tentamos demonstrar com Sullivan e Keller.

Mas voltemos um pouco ainda sobre o discurso universitário, já que a pedagogia ortodoxa é sua correlata, embora "uma" educação, necessariamente, não.

Enquanto o discurso do mestre é comandado por um significante mestre apresentado ao outro como $O$ Saber para satisfazer o desejo (cf. NOGUEIRA, 1999), o discurso universitário segue o comando do saber estabelecido na pretensão de dar conta do desejo adaptado e, portanto, adequado. Todavia, por seu funcionamento lábil e inconsciente, ainda que o desejo possa ser realizado, não será jamais satisfeito, quanto mais adaptado ou adequado. A desnatureza mesma do desejo é precisamente sua inadequação. Adequado e natural é o instinto, não a pulsão...

No discurso universitário são os títulos que garantem o valor de um saber. O que é bem diferente de dizer que é a inquietação do sujeito sempre dividido, embaraçado, que está no lugar da verdade no discurso do mestre. Ao contrário, no discurso universitário, o saber se conta em títulos acadêmicos, pouco importando se esses títulos efetivamente condizem a algum estofo do sujeito (ALBERTI, 2000).

Moralidade lacaniana: o discurso universitário produz sujeitos aos quais se dirige como a "créditos". Pretende dominar a verdade por meio da técnica e concebe o saber como uma distribuição pluridisciplinar: age portanto em nome do próprio saber (ROUDINESCO, 2008, p. 470).

Interessante observar, nos Anexos do Seminário 17: O avesso da psicanálise, as respostas de Lacan às intervenções na maioria das vezes bastante agressivas dos universitários de Vincennes. Dentre vários adjetivos endereçados a ele, talvez os mais elogiosos tenham sido "um belo palhaço, célebre, que fala para nada dizer". Dentre as breves respostas que Lacan dá aos estudantes, tomamos a liberdade de selecionar o que, nesse momento, parece vir a calhar:

Vocês são o produto da Universidade, e comprovam que a mais-valia são vocês, quando menos no seguinte, que não apenas consentem, mas aplaudem, e ao que eu não teria por que fazer objeções - é que saem dali vocês próprios 
equiparados a mais ou menos créditos. Vocês vêm aqui tornar-se créditos. Saem daqui etiquetados como créditos, unidades de valor. (...) A propriedade de cada um desses esqueminhas de quatro patas é a de deixar uma hiância. No plano do discurso do mestre, é precisamente a da recuperação da mais-valia. No plano do discurso universitário, é uma outra. E esta é a que atormenta vocês. Não que o saber que lhes é dado não seja estruturado e sólido, tanto que só lhes resta fazer uma coisa, entrelaçarem-se dentro dele com os que trabalham, quer dizer, aqueles que ensinam a vocês, na condição de meios de produção e simultaneamente de mais-valia. Quanto ao discurso da histérica, foi este que permitiu a passagem decisiva, dando seu sentido ao que Marx historicamente articulou. Que é, a saber, existirem acontecimentos históricos que só podem ser julgados em termos de sintomas. Não se viu aonde isso chegaria até o dia em que se dispôs do discurso da histérica para fazer a passagem com uma outra coisa, que é o discurso do psicanalista. O psicanalista, de início, teve apenas que escutar o que a histérica dizia (LACAN, 1992, p. 212-214).

A hiância que tanto atormenta os estudantes - Lacan não explicita, mas transmite advém da posição do universitário, cuja verdade da enunciação deve ser recalcada para dar vazão ao que é produzido enquanto iteração, feito mais-valia produzida, mas renunciada ao gasto, reinvestida como deve ser para aumentar o capital. Discurso universitário compatível com o do capitalista, quando o conhecimento se torna ecolálico, bancário e cientificista. Embora, frisamos nós, não precisem ser exatamente esses os discursos em pauta no educar.

Segundo Roudinesco (2008, p. 471-72), o Seminário 17: O avesso da psicanálise continha uma grande lição de lucidez por parte de seu autor, pois foi naquele ano em que Lacan interrogou-se ao mesmo tempo:

(...) sobre o devir de uma universidade cada vez mais reduzida a uma função psicopedagógica, e sobre as condições de transmissão do saber freudiano numa sociedade em que as massas substituíam doravante as elites [eruditas]. Após ter sido Sócrates, Lacan imaginava-se um rei Ubu, como se já pressentisse, no auge da glória, a implosão crepuscular de seu próprio pensamento (acréscimo nosso).

(Continuação da carta de 8 de maio de 1887.)

(...) Ainda há pouco, Helen veio correndo pela escada acima e, entrando no quarto muito agitada, escreveu as palavras "cachorro e bebê", depois do que contou os cinco dedos da mão, chupando-os em seguida. Pensei que um dos cães tivesse machucado sua irmãzinha [Mildred], mas a cara dela me tranquilizou. Não conseguindo interpretar o que dizia, resolvi acompanhá-la, e ela me levou até a casinhola dos cachorros, onde uma cadela acabava de ter cinco bichinhos que mamavam. Interessou-se vivamente por eles, escrevendo muitas vezes "mãe-cachorro" e "filhote". Como notou que eles estavam de olhos fechados, escreveu "olhos fechados" e "não dormem" .(...) Começou a indicar os filhotes um por um, repetindo depois a operação nos dedos, o que me deu a ideia de ensinar-lhe a palavra "cinco". Então ela levantou um 
dedinho, escrevendo a palavra "bebê". Como achei que Helen estava pensando em Mildred, escrevi em sua mão "um bebê e cinco filhotes". Depois de brincar um pouco com os cachorrinhos, lembrou-se de que eles deviam ter nomes como as pessoas, começando então a indicar um por um, perguntando que nome tinham. Tendo-lhe dito que perguntasse ao pai, respondeu-me: "Não-mãe". Vi que ela acha que as mães entendem melhor de qualquer recém-nascido do que os pais. Como notasse que um filhote era bem pequeno, escreveu "pequeno", fazendo o sinal antigo. Aproveitei para ensinar-lhe 'muito pequeno'. Positivamente, Helen compreendeu a significação de 'muito', porque ficou empregando a palavra corretamente. Já no caminho, encontrando uma pedrinha, escreveu: "pedra muito pequena". Logo depois começou a dar passos largos para escrever "grande", a dar outros menores empregando "pequenos" e enfim, outros miúdos para dizer "muito pequenos" (Anne Sullivan, in KELLER, 2001, p. 202-3, acréscimo nosso).

- Nesta que não deixa de ser uma narrativa, por exemplo, o leitor encontra traços de quais discursos?

Retomando ao funcionamento dos "pequenos quadrípodes" - que uma didática, quando não magnânima, também interessa -, voltemos às setas. Como havíamos dito anteriormente, as setas nos matemas dos discursos indicam a direção do circuito entre os elementos, como também a determinação entre os mesmos. Nos discursos do mestre, da universidade, do analista e da histeria, é da verdade sob a barra do recalque que saem duas setas, uma em direção ao agente e outra em direção ao outro, sem, no entanto, receber nenhuma em sua direção. Por sua vez, o agente que se dirige ao outro, determina-o para, a seguir, receber a determinação do produto do discurso proferido; enquanto o que está na posição de outro determina aquilo que produz e, concomitantemente, recebe a determinação do que está no lugar da verdade. Cabe ressaltar, mais uma e uma vez, que em nenhum momento o produto determina a verdade, deixando uma abertura, ou uma falha no circuito das flechas. O que de fato faz a diferença. Ao sair em busca de algo que deseja, o sujeito pode até atingir seu alvo a contento, contudo o objeto circulado no enlaçamento carregará sempre uma diferença de não ser exatamente aquilo que se imaginou a priori, fato que deixa um resto, isso que Lacan aponta como a produção de uma mais-valia de gozo, a ser reinvestida pelo registro do desejo em novas tentativas de buscas e enlaces ao camaleônico e fugaz objeto $\boldsymbol{a}$. De maneira singular, posto que a verdade só pode ser meio-dita, também o objeto causa de desejo, nos parece, só pode ser meio-achado... o que não é de todo mal, já que esta é justamente uma garantia para que civilização siga seu trajeto de procuras e (des)encontros, de enlaces e desenlaces, de fazer cultura-sobre-cultura.

De qualquer maneira, mostram os matemas, é pelo furo dos discursos que se enlaçam os sujeitos, fazendo tramas e tecidos no processo civilizatório, na exigência constante da 
renúncia pulsional e da impossibilidade de se aplacarem sujeito e objeto, este que é o custo do desejo. Tal aplacamento, todavia, encontra seu termo no dispositivo discursivo capitalista, por ser este um discurso sem Lei:

(...) que não tem regulação alguma e que, longe de regular as relações entre os homens, segrega. Sua única via de tratar as diferenças é pela segregação imposta pelo mercado, determinando os que têm ou não acesso aos produtos da ciência. Daí a proliferação do sem: terra, teto, emprego, comida, documentos, etc (QUINET, 2001).

Quando o discurso modula-se em nome do registro universitário a validar análises e conclusões através de metodologias empírico-quantitativas, não é raro que se incorra não no discurso da Ciência, ou da Universidade, mas no do Capitalista, como escutamos nos discursos do economista e da tecnocrata lá de trás:

(...) quando o discurso do mestre se coloca a serviço do cientificismo, (...) reduz tudo a números, a estatísticas, a unidades de valor e o outro passa a ser mera unidade de valor de forma que até mesmo o mais-de-gozar passa a ser contabilizado (ALBERTI, 2000).

\subsubsection{Discurso do Capitalista}

Observemos a metamorfose perversa do mestre ao capitalista:
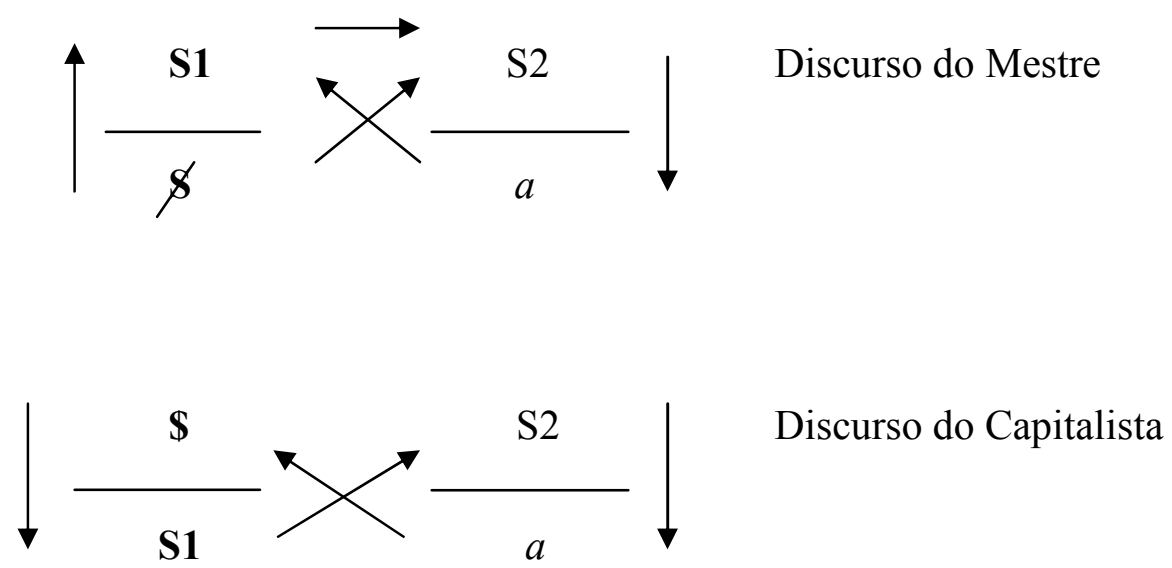

É preciso notar a sutil mudança feita na direção da seta entre as posições do agente e da verdade. No discurso do capitalista, o agente $\$$ passa a determinar a verdade, 
manipulando-a, na desconsideração do recalque, como havíamos dito. O matema que antes tropeçava no impossível, agora gira em looping, porque suturado o furo, a bainha, a hiância. $\mathrm{Na}$ corrupção do lugar da verdade, desaparece a verdade-verdadeira e resta o gozodogozodogozodogozoœ.

1 de janeiro de 1888 .

É uma grande coisa a gente sentir que tem alguma utilidade neste mundo e que está sendo necessária a outro ser. A maneira como Helen depende de mim para quase tudo enche-me de alegria. A semana do Natal foi muito trabalhosa por aqui. Helen foi convidada a todas as festas infantis, e eu a levei a quase todas. Quero que ela trave conhecimento com as crianças, convivendo com elas o mais possível. Várias crianças já se orgulham de saber falar com ela pelo alfabeto manual. (...) Há várias semanas só temos conversado e contado histórias sobre o Natal. Não procuro explicar, palavra por palavra, as leituras a Helen, preferindo que as constantes repetições acabem por fazê-la descobrir o sentido de muitos vocábulos. A leitura e a conversação não devem ser tornadas estéreis pela constante dissecação de palavras isoladas. Cumpre procurar o prazer da idéia, acima de tudo. Desejo que Helen fale pelo desejo de dizer-me alguma coisa que pensa ou sente, e não pela obrigação de formar frases com determinadas palavras. Quando ela se acha embaraçada por não encontrar como exprimir o que quer, ajudo-a de modo que chegue ao fim. A ansiedade e o interesse que sente por transmitir suas idéias vão levando de vencida os obstáculos, sem o exame detalhado das palavras. Creio que se me forçassem a definir as palavras mais simples que uso constantemente, eu acabaria no primeiro ano do curso primário para débeis mentais (Anne Sullivan, in KELLER, 2001, p. 216-7).

Foi na conferência de Milão, em 12 de maio de 1972, que Lacan mostrou a inversão no matema do mestre em discurso do capitalista.

El semblante ya no es significante amo que recibe su determinación de la verdad, sino que es el sujeto, entronizado como agente, quien opera sobre el significante amo colocado en el lugar de la verdad. Tal manipulación de la verdad es un rechazo de la castración del discurso conducente a establecer una circularidad sin interrupciones. Por este motivo, y por el hecho de que el circuito se halla orientado hacia la izquierda [ao contrário dos outros quatro discursos], hablamos de "círculo siniestro" (ALEMÁN ; LARRIERA, 1996, p. 178).

De fato, afirma Lacan (1991, p. 188-189) alicerçado na Dialética do Senhor e do Escravo, de Hegel e em O Capital, de Marx:

Alguma coisa mudou no discurso do mestre a partir de um certo momento da história. Não vamos esquentar a cabeça para saber se foi por causa de Lutero, ou de Calvino, ou de não sei que tráfico de navios em torno de Gênova, ou no Mar Mediterrâneo, ou alhures, pois o importante é que a partir de um certo 
dia, o mais-de-gozar se conta, se totaliza. Eis quando começa o que chamamos a acumulação de capital.

Em lugar da castração, o discurso capitalista promove o onanismo do consumo rápido e descartável de quinquilharias, parceiros, teorias, mas também dos multiprodutos da indústria cultural através da objetalização do outro transformado em consumidor, formatado para aumentar o capital. O mercado escolar, por exemplo, quando toma o sujeito em processo de crescimento e humanização no registro de $A$-Criança $a^{90}$, como descrito por Lajonquière recentemente, não acaba produzindo grande parte do alunado exatamente nesta posição de gadget ou fetiche? Nesse discurso, S1 se dirige a S2, pondo o gozo deste a seu serviço, formando o circuito que se retroalimenta. Eis de fato o circuito sinistro e perverso que não exige renúncia, mas ao contrário, que instiga a pulsão, impondo ao sujeito determinadas relações com a demanda, sem se dar conta que, ao fazê-lo, está na sustentação da pulsão de morte (cf. ALBERTI, 2000).

O mal-estar, portanto, é o produto dos discursos dominantes em nossa civilização: discurso do mestre, universitário e do capitalista (...) O mal-estar da civilização dominada pela ciência, como a nossa, se apresenta hoje como doenças predominantemente oriundas do discurso do capitalista, a nova e hegemônica modalidade do discurso do mestre que promove um autismo induzido e um empuxo ao onanismo, fazendo a economia do desejo do Outro e estimulando a ilusão de completude (QUINET, 2001).

Sintomas provocados pelo rechaço do desejo e pela recusa à palavra enunciada pelo sujeito $^{91}$. Sintomas, também nos campos da educação: enquanto aos educandos um rol de deficiências e dificuldades são nomeadas e distribuídas nos consultórios "psis", a síndrome de Burnout está reservada também a professores exaustos e deprimidos. "Ladainhas" de professor? Não, desconsideração obscena de burocratas da educação. Rechaço do sujeito legitimado pelo discurso capitalista, encampado pelo Estado. O fracasso em larga escala, apontando para vários agentes: instâncias governamentais, diretores, coordenadores, funcionários, educandos, pais. Para-educadores de todos os naipes, farmacêutica de última geração, todos chamados a ajudar na sustentação do trabalho que, antes, se mantinha

\footnotetext{
${ }^{90}$ A-Criança , segundo o autor, é uma construção fantasística do mundo moderno, que toma a criança como ser desprovido de qualquer marca do desejo sexual e infantil, produto da naturalização violenta da infância. "Esse ser natural, dotado de direitos e necessidades educativas mais ou menos especiais, porém sempre clamante de satisfação, virou parâmetro comportamental onipresente na vida junto a esses seres pequenos, que temos o hábito, até agora, de chamarmos de crianças" (LAJONQUIÈRE, 2010, p. 19). Sobre A-Criança, a racionalidade tecnocientificista tudo põe a investigar e a saber, instrumentando o adulto no endereçamento supostamente adequado a tal criatura, esta que se supõe, então, imutável e fora do tempo. Desta feita, $A$-Criança, é tomada bem como a criança que não existe, embora o "adulto" pós- moderno insista em afirmá-la.

${ }^{91}$ A esse respeito, ver Richard Sennet, A corrosão do caráter : Consequências pessoais do trabalho no novo capitalismo, Record, 2005.
} 
circunscrito aos desdobramentos possíveis no ambiente escolar, sendo os impasses dissolvidos (ou não), sem maiores diagnoses, nem medicações. Ao candidato a estudante, diplomas como tíquetes que prometem a entrada no mercado de trabalho são ofertados, embora muitas vezes não passem de ledo engodo. Além de oferecer titulações de todos os naipes - cada vez mais baratas e rápidas -, a escolarização obrigatória que um dia foi inventada em nome da igualdade de oportunidades e direitos do cidadão republicano serve, hoje, à movimentação do mercado da educação, cooptando na criação de produtos e instituições destinados a dar conta das ditas necessidades educativas especiais, não só físicas, mas também "psíquicas". Exemplos são as escolas especializadas na clientela diagnosticada como disléxica, hiperativa, deficitária na atenção, agora também com pânico escolar, sem falarmos na nova leva de psicotrópicos para-pedagógicos cujo consumo crescente em nível mundial se faz em nome da atenção e calma necessárias a uma educação planejada e pregada como ideal.

Sintomas.

- Mas dá-lhes Ritalina, porque nas baladas, nossos TDAHHHHHHprendem rapidamente a tomá-la em grupo, intercalada com destilados. Evoé, Baco!!! Ió! Ió! Ió!

\subsection{5 - Discursos da Histeria e do Analista}

Por fim, o Discurso da Histeria:

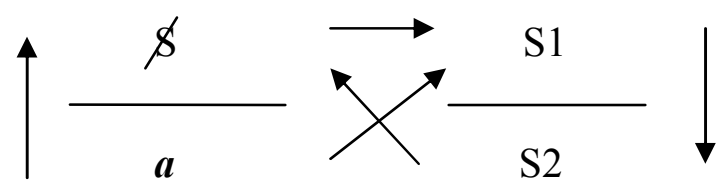

Aqui, o sujeito barrado está também na posição de agente, mas sobre o recalque daquilo que faz falta, o objeto $a$, Shá verdade. A seta, de baixo para cima, faz que o pequeno $a$ esteja na determinação do discurso do agente, por onde escorrega a enunciação em direção ao saber do significante mestre, S1, colocado na posição de objeto como aquele que sabe, supostamente capaz de entregar ao agente do discurso o saber produzido sobre ele, $\$$, como demonstra a flecha que sai de S2 em direção ao $\$$. Este seria o circuito do funcionamento psíquico da histeria em análise, quando o analisante imagina e demanda ao 
outro (analista) que trabalhe por ele, produzindo um saber que explicite o real que o mantém rodando em círculos, seu sintoma - o que é de fato impossível, porque o analista não sabe, embora se ofereça no lugar de sujeito suposto saber. Assim, o "efeito deste discurso é provocar o saber, porque desafia a autoridade, a teoria estabelecida, propondo insistentemente a dúvida sobre o saber do Outro" (ZILIOTTO, 2004).

A histérica, partindo de sua divisão subjetiva, questiona o mestre, ou seja, questiona tudo o que está estabelecido, e é inegável que tal posição discursiva produz resultados preciosos para o saber e a ciência. O próprio advento da psicanálise é efeito desse posicionamento (MAURANO, 2007).

Por conseguinte, o discurso da histeria guardaria proximidade ao discurso da ciência pela estrutura de produção de saber, embora seja necessário distinguir a histeria referida à neurose , da forma de relacionamento humano em que um sujeito provoca no outro o desejo e a criação de um saber sobre o real (cf. QUINET , 2002, p. 32).

A ciência também pode entrar na categoria de discurso como enquadramento do gozo na medida em que tem por finalidade a conquista do real, ou seja, a colonização do real pelos aparelhos simbólicos que as formas matemáticas representam. (...) em contraposição a uma ciência universalizante, só é possível uma ética do particular como propõe a psicanálise, que inclua o sujeito cuja essência, segundo Espinoza, é o desejo (Idem, ibidem, p. 33).

Se prestarmos atenção às flechas do matema no discurso da histeria, veremos que a posição do outro a quem é atribuído o suposto saber, S1, recebe a seta de determinação do pequeno $a$ localizado abaixo do recalque de $\$$, de forma que, em verdade, S1 não detém o saber sobre o agente, uma vez que ambos, $\$$ e S1, sofrem a determinação da castração e da falta-a-ser. Eis por onde o discurso da histérica enlaça-se no discurso do analista, como foi possível a Freud dar essa demonstração já que, em semblante, aprendeu a ocupar o lugar de sujeito suposto saber imposto pelas histéricas, sem identificar-se todavia com ele, por darse conta que não detinha o saber suposto sobre o gozo delas, apesar delas acharem que sim. Por razões que talvez a razão desconheça, de alguma forma Freud intuiu que somente os próprios pacientes poderiam produzir, enquanto $\mathrm{S} 1$, uma re-significação mestra para si. Recalcando o saber estabelecido da medicina, portanto S2, ao mesmo tempo em que fazia o paciente discorrer livremente sobre aquilo que o fazia sofrer, Freud acabou inaugurando outra forma de discurso cujo agente, na posição de pequeno $a$ - o analista - , abria mão da fala de mestre (embora fosse neurologista!) para escutar o bem-dizer da meia-verdade do $\$$, tal como ocorreu quando Anna O, em pedido-mando, sugerindo-lhe que ficasse quieto para somente ouvi-la falar, a fim de poder fazer o que metaforizou como "limpeza da chaminé". Assim foi 
inventado o talking cure, associação livre de representações configurada como matriz da terapêutica psicanalítica. Em última instância, espécie de tentativa de cura cujos instrumentos por excelência, fala e linguagem, são postos para circular o toro do real.

Ainda que não possamos dizer se Anne Sullivan era histérica ou não, porque pouco importa, o discurso da histeria mostra-se presente também em seus dispositivos discursivos, como atestam a leitura atenta dos escritos de mestra e aluna.

Resta-nos ainda o discurso do analista, o quarto de giro anti-horário em relação ao discurso histérico.

Enquanto o discurso da histeria é comandado pelo sujeito questionador no sentido de fazer com que o outro produza o saber, o discurso analítico é comandado pelo analista posicionado na função de objeto causa do desejo do analisante, portanto como semblante, na tentativa de encaminhar o analisante à produção de um Outro significante mestre, como podemos apreender no matema abaixo:

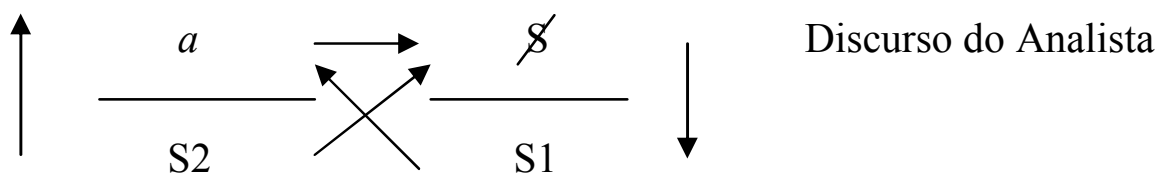

O psicanalista se dirige ao outro de uma forma radicalmente nova na cultura, tomando-o como sujeito falante capaz de produzir os significantes primordiais fundadores da sua própria história, (cf. COUTINHO JORGE, 2003, p. 49). Nesse sentido, é o único discurso que considera o outro como sujeito do desejo, de maneira distinta ao discurso da universidade - quando esse considera o outro como objeto a ser dominado pelo saber estabelecido pela comunidade acadêmica, tal como ocorreu com Victor de Aveyron -; do discurso do capitalista - que considera o outro como mero objeto para o consumo -; do discurso do mestre - que toma o outro como um ser servil - ; e da histérica - para quem o outro é sujeito suposto saber. Por conseguinte, enquanto no discurso universitário o agente fala sobre o sujeito melhor seria dizer sobre o indivíduo - no discurso do analista o agente, em semblante, fala com o sujeito.

O discurso do analista se coloca como a modalidade de tratamento [leia-se terapêutica] do mal-estar que considera o outro como um sujeito - sujeito do inconsciente, do desejo, mas também de direito e da história. Contra o 
imperativo do discurso do capitalista, a psicanálise propõe essa falta que se chama desejo, sempre singular e plural, e a gestão não do capital financeiro, mas do capital da libido que por definição está sempre no negativo. E contra a segregação que dele deriva, ela traz a ética da diferença (QUINET, 2001, acréscimo nosso).

Em Televisão, texto de 1974, Lacan se refere pela última vez ao discurso do capitalista, dizendo: "Quanto mais somos santos mais rimos, é o meu princípio, ou seja, é a saída do discurso do capitalista, o que não constituirá um progresso se for somente para alguns". Segundo Alberti (2000), o santo a que Lacan se refere é o lugar do psicanalista enquanto rebotalho que não faz caridade, mas que se torna a única saída para o looping do aplacamento sujeito-objeto/objeto-sujeito pois, ao se oferecer ao analisante enquanto objeto causa de desejo, evitando identificar-se ao discurso do analisante, faz com que barre o discurso do capitalista pelo qual o sujeito se crê agente não se dando conta de que age somente a partir da determinação dos objetos de consumo oferecidos para aplacar-lhe a faltaa-ser, ainda que, em função do capital como se encontra, ainda se imagine no controle desse viver consumidor. Por isso o riso irônico do analista, que no intuito de restituir a verdade à histeria, recusa-se a creditar nas verdades que não são.

28 de agosto de 1887.

O espírito de Helen não para. Novos filhotes, novos bezerros e novas crianças são motivos para seus dilúvios de "por quê" e "onde". Outro dia, nasceu uma criança em Ivy Green, e lá veio a menina com uma série de perguntas sobre a origem das crianças. "Onde Leila arranjou o filhinho?", "Como é que o doutor sabe onde estão os bebês?", "Leila pediu seu filhinho ao doutor?", "Onde é que o doutor arranjou Guy e Prince?" (dois filhotes), "Por que é que Elisabeth é irmã de Evelyn?". Com essas e outras perguntas, Helen deixa-me constantemente embaraçada. Acho-me no dever de explicarlhe os fatos com clareza, evitando tolices que só podem obstar o desenvolvimento de seu intelecto. Desde o início, tenho procurado sempre dizer as coisas à minha aluna com o máximo de verdade, à altura de sua compreensão. Antes de dar-lhe as lições, leio os livros, procurando vencer minha deplorável ignorância em alguns assuntos de física e história natural. Falo-lhe em linguagem simples e sincera. Eu a fiz plantar grãos de feijão e sementes de melancia, para que ela observasse a germinação e eu lhe explicasse o processo de crescimento das plantas. Disse-lhe que a terra e o calor aquecem estas sementes, até que elas tenham força para brotar. Fazendo então analogia com os ovos, expliquei que assim a galinha guarda o ovo aquecido dentro de si, até que ele tenha força para sair e transformar-se em pinto. Assim, de comparação em comparação vou penetrando com ela nos mistérios da vida. Disse-lhe que "o ovo é o berço da vida"; que alguns animais criam os ovos dentro de si, pondo-os depois em lugares onde sabem que podem acabar de germinar; e que outros, como os cães e as criaturas humanas, conservam o ovo dentro de si até que dele saia, já pronto, o filho. Expliquei-lhe que, se assim não fosse, a vida na Terra acabaria. Passando 
embora o mais brevemente possível, sobre a função sexual, dei-lhe a entender que o amor é o grande continuador da vida. A facilidade com que minha aluna compreende todas essas explicações, apesar de minhas insuficiências, acabou por convencer-me de que ao nascer, a criança já traz incubadas as experiências da espécie. É como se tais experiências fossem filmes fotográficos, que vão sendo revelados pelo uso da linguagem e pelas faculdades intelectuais (Anne Sullivan, in KELLER, 2001, p. 210-11).

- Para educ(a)r, Annie soube inventar para si e para Helen a arte de circular o toro. 


\section{Aula}

Nosso professor de latim, Mestre Aristeu, era magro e do Piauí. Falou que estava cansado de genitivos, dativos, ablativos e de outras desinências. Gostaria agora de escrever um livro. Usaria um idioma de larvas incendiadas. Epa! o prof. falseou-ciciou um colega. Idioma de larvas incendiadas! Mestre Aristeu continuou: quisera uma linguagem que obedecesse a desordem das falas infantis do que as ordens gramaticais. Desfazer o normal há de ser uma norma. Pois eu quisera modificar nosso idioma com as minhas particularidades. Eu queria só descobrir e não descrever. O imprevisto fosse mais atraente do que o dejá visto. O desespero fosse mais atraente do que a esperança. Epa! o prof. desalterou de novo - outro colega nosso denunciou. Porque o desespero é sempre o que não se espera. Verbi gratia: um tropicão na pedra ou uma sintaxe insólita. O que eu não gosto é de uma palavra de tanque. Porque as palavras do tanque são estagnadas, estanques, acostumadas. E podem até pegar mofo. Quisera um idioma de larvas incendiadas. Palavras que fossem de fontes e não de tanques. E um pouco exaltado o nosso prof. disse: Falo de poesia, meus queridos alunos. Poesia é o mel das palavras! Eu sou um enxame! Epa!... Nisso entra o diretor do Colégio que assistira a aula de fora. Falou: Seo enxame espere-me no meu gabinete. O senhor está ensinando bobagens aos nossos alunos. O nosso mestre foi saindo da sala, meio rindo a chorar.

Manoel de Barros

Memórias Inventadas: A Segunda Infância 


\section{Um olhar}

Eu tinha uma namorada que via errado. O que ela via não era uma garça na beira do rio. O que ela via era um rio na beira da garça. Ela despraticava as normas. Dizia que seu avesso era mais visível do que um poste. Com ela as coisas tinham que mudar de comportamento. Aliás, a moça me contou uma vez que tinha encontros diários com as contradições. Acho que essa frequência nos desencontros ajudava o seu ver oblíquo. Falou por acréscimo que ela não contemplava as paisagens. Que eram as paisagens que a contemplavam. Chegou a ir no oculista. Não era um defeito físico falou o diagnóstico. Induziu que poderia ser uma disfunção da alma. Mas ela falou que a ciência não tem lógica. Porque viver não tem lógica - como diria a nossa Lispector. Veja isso: Rimbaud botou a Beleza nos joelhos e viu que a Beleza é amarga. Tem lógica? Também ela quis trocar por duas andorinhas os urubus que avoavam no Ocaso de seu avô. O Ocaso de seu avô tinha virado uma praga de urubu. Ela queria trocar porque as andorinhas eram amoráveis e os urubus eram carniceiros. Ela não tinha certeza se essa troca podia ser feita. O pai falou que verbalmente podia. Que era só despraticar as normas. Achei certo.

Manoel de Barros

Memórias Inventadas: A Segunda Infância 


\section{O ato educ(a)tivo de Anne Sullivan}

Fala-se da dificuldade entre forma e conteúdo, em matéria de escrever; até se diz: o conteúdo é bom, mas a forma não etc. Mas, por Deus, o problema é que não há de um lado um conteúdo e de outro

a forma. Assim seria fácil: seria como relatar através da forma o que já existisse livre, o conteúdo. Mas a luta entre a forma e o conteúdo luta por se formar. Para falar a verdade, não se pode pensar num conteúdo sem forma. A intuição é a funda reflexão inconsciente que prescinde de forma enquanto ela própria, antes de subir à tona,

se trabalha. Parece-me que a forma já aparece quando o ser todo está com o conteúdo maduro, já que se quer dividir o pensar ou o escrever em duas fases. A dificuldade de forma está no próprio constituir-se do conteúdo, no próprio pensar ou sentir, que não saberiam existir sem sua forma adequada e às vezes única.

Clarice Lispector

Em Estrutura e Constituição da Clínica Psicanalítica ${ }^{92}$, Dunker apresenta sua hipótese arqueológica sobre a evolução histórica dos conceitos que caracterizam a Psicanálise não apenas como terapêutica, mas como discurso e forma de saber. A tese oferece uma longa viagem por tempos e pensamentos, alinhavando ao estofo da Psicanálise legados de Homero, Empédocles, Sófocles, Epicuro, Aristóteles, Montaigne, Descartes, Kant, Hegel, Heiddeger, Foucault, entre outros. Para a argumentação que tentamos construir, uma das conclusões sobre a clínica psicanalítica nos interessa sobremaneira porque nos parece possível remetê-la, também, ao âmbito do educar, qual seja, que ela não deve ser compreendida como ciência, mas como experiência.

No capítulo sobre a formação do espaço patológico, Dunker afirma encontrar “(...) na antropologia kantiana uma forma de descrição, classificação e análise inteiramente baseada no uso cultural específico da linguagem" (p. 171), quando as palavras, segundo seu emprego e

\footnotetext{
${ }^{92} \mathrm{O}$ texto citado foi disponibilizado pelo autor aos alunos da disciplina Problemas da Metapsicologia Lacaniana ministrada no IPUSP, em 2007; constou da bibliografia básica para as discussões em sala de aula e elaboração de seminários em grupo, sendo a tese apresentada para o concurso de livre-docência. Em final de 2010, sob o título "Constitution of Psychoanalitic Clinic - history of its structure and power", o livro foi publicado na Inglaterra e na Irlanda.
} 
uso comum passam a formar a matéria a ser examinada nas doenças e afecções mentais. A importância conferida por Lacan ao significante, por exemplo, tal como é efetivamente pronunciado pelo paciente na experiência analítica, tomaria a mesma direção. Segundo Dunker, o que ocorre na clínica psicanalítica trata-se de uma explicitação da linguagem em sua relação com a acepção forte do termo experiência (erfahrung):

A palavra vem de fahren, viajar, vaguear ou realizar uma jornada. Ambiguamente ele designa tanto o processo quanto seu resultado em ambiguidade similar à que encontramos no termo cura. Como falar de uma viagem que fiz? Posso contar as vivências (Erlebnis) que tive, os momentos intensos e as sensações inusitadas, posso apresentar registros ou arquivos e invocar testemunhas, mas a mera descrição do deslocamento no espaço e a ocupação do tempo não fazem de minha viagem uma verdadeira experiência. $\mathrm{O}$ que interessa para saber se houve experiência é saber como essa viagem me transformou, como depois dela não sou mais o mesmo que era antes; como me apreendi de forma exterior, a partir de fora, a partir de onde não sou, como o radical "ex" de "experiência" sugere. Mas também como vagueei, como experimentei a incerteza, a prova, a tentativa em torno de algo, conforme o radical "peri" de "experiência" indica. Portanto, a experiência não é o empírico nem o fenômeno, não é o dado imediato da consciência, nem mesmo a apresentação controlada dos objetos. A experiência é sempre um percurso do sujeito, a partir do qual se torna o que ele é (DUNKER, 2007, p. 172).

Sendo que a condição da experiência

(...) não é a realidade, nem apenas a distância ética entre o ser e o dever, ou a separação entre o dever e o poder, mas o conflito, a disparidade e a contradição que caracterizam a ocupação deste espaço pelas formas do desejo e da satisfação (Idem, ibidem, p. 176).

Por nos ajudar a pensar o trabalho pedagógico-educativo que Anne Sullivan pôde oferecer aos Keller, a si mesma, à educação especial e à pedagogia de modo geral, tomamos a liberdade de apontarmos o processo educativo também enquanto experiência e percurso, não por motivo de cura ou tratamento, mas de prática subjetivação.

Visto que para nós a palavra constitui o instrumento educativo por excelência, endereçar-se ao outro na função de educador parece inclinar-se muito mais à tentativa de levar o sujeito, pela palavra, a vagamundear pela cultura na articulação entre passado, presente e futuro, do que manter-se na reprodução de procedimentos pedagógicos padrões ancorados naquilo que o discurso universitário prega como gênese e funcionamento da inteligência humana com vistas a atingir a aprendizagem ideal - registro que não ultrapassa o âmbito do par estímulo-resposta, portanto. Endereçar-se ao outro na função de educador, para longe das fronteiras procedimentais padrões, parece guardar proximidades com ao erfahrung descrito acima, na tentativa de levar e trazer o aluno a vaguear com ele, educador, 
em torno deste ou daquele objeto socialmente valorizado pela cultura, numa experiência capaz, ou não, de provocar transformações subjetivas. Porque aluno não é objeto para download, há que se levar em conta a possibilidade de sua recusa, de resistir a responder em consonância à demanda educativa, seja de modo consciente, ou não. Cabe ao educador, entretanto, tentar e retentar o acesso. Não por acaso Antônio Cândido defendeu, por exemplo, a literatura como um Direito Humano no interior do processo educativo, justamente porque é um recurso da cultura que permite, seja qual espécie de fabulação, humanizar, independentemente do uso que o aluno fará dela.

No âmbito da instrução escolar o livro chega a gerar conflitos, porque o seu efeito transcende as normas estabelecidas. Numa palestra feita há mais de quinze anos em reunião da Sociedade Brasileira para o Progresso da Ciência sobre o papel da literatura na formação do homem, chamei a atenção entre outras coisas para os aspectos paradoxais desse papel, na medida em que os educadores ao mesmo tempo preconizam e temem o efeito dos textos literários. De fato (dizia eu), há "conflito entre a ideia convencional de uma literatura ${ }^{93}$ que eleva e edifica (segundo os padrões oficiais) e a sua poderosa força indiscriminada de iniciação na vida, com uma variada complexidade nem sempre desejada pelos educadores. Ela não corrompe nem edifica, portanto; mas, trazendo livremente em si o que chamamos o bem e o que chamamos o mal, humaniza em sentido profundo, porque faz viver. A função da literatura está ligada à complexidade da sua natureza, que explica inclusive o papel contraditório mas humanizador (talvez humanizador porque contraditório) (CANDIDO, 2004, p. 176).

E complementa:

(...) A literatura pode formar; mas não segundo a pedagogia oficial. (...) Longe de ser um apêndice da instrução moral e cívica, (...), ela age com o impacto indiscriminado da própria vida e educa como ela. (...) Dado que a literatura ensina na medida em que atua com toda a sua gama, é artificial querer que ela funcione como os manuais de virtude e boa conduta. E a sociedade não pode senão escolher o que em cada momento lhe parece adaptado aos seus fins, pois mesmo as obras consideradas indispensáveis para a formação do moço trazem frequentemente aquilo que as convenções desejariam banir. (...) É um dos meios por que o jovem entra em contato com realidades que se tenciona escamotear-lhe. (...) Um certo tipo de função psicológica é talvez a primeira coisa que nos ocorre quando pensamos no papel da literatura. A produção e fruição desta se baseiam numa espécie de necessidade universal de ficção e de fantasia, que decerto é coextensiva ao homem, pois aparece invariavelmente

\footnotetext{
93 "Chamarei de literatura, de maneira mais ampla possível, todas as criações de toque poético, ficcional ou dramático, em todos os níveis de uma sociedade, em todos os tipos de cultura, desde o que chamamos folclore, lenda, até as formas mais complexas e difíceis das grandes civilizações. Vista desse modo, a Literatura aparece claramente como manifestação universal de todos os homens em todos os tempos. Não há povo e não há homem que possa viver sem ela, isto é, sem encontrar em contato com alguma espécie de fabulação" (CANDIDO, 2004, p. 174).
} 
em sua vida, como indivíduo e como grupo, ao lado da satisfação das necessidades mais elementares (CANDIDO, 1972, p. 805).

De qualquer maneira, caso a psique humana funcione mesmo como uma espécie de maquinário - ou aparelho psíquico, como nomeou Freud - , a dificuldade e a beleza é que, também na dinâmica do aprender, ou seja, nessa que pode verdadeiramente se tornar erfahrung, o leitmotiv dos fenômenos "inteligentes" ou neuronais encontrar-se-á muito além das propriedades bio-físico-químicas do cérebro, já que o combustível para aparelho tão complexo e plástico, com ligações pelos caminhos de todo corpo, compõe-se também de libido $^{94}$, detalhe substancial capaz de subverter toda ordem e progresso.

*_*_*

Uma das primeiras lições a se aprender com o estudo da psicanálise é que a escolha das palavras nunca se mostra desimportante. Em escritos com intenções acadêmicas, mais que obrigação metodológica, é tal qual cuidado de verossimilhanças para quem pretende escrever literaturas, entendi. Logo, se escolhemos ato (educ(a)tivo), foi para não utilizar ação (educativa), já que Lacan faz uma diferença entre os termos, aparentemente sinônimos. Para além do sentido de movimento, porque também não deixa de ser, precisa Lacan, ato significa alguma coisa que traz consigo, nos meandros da ação, uma mudança, algo inaugural, marcando a diferença. Sullivan não fazia outra coisa que marcar e remarcar a diferença.

Os livros que não se achavam em Braile tinham de ser lidos em minha mão, depressa bastante para me deixarem em dia com os estudos. Tinha assim, de estudar lentamente, e esgotando a paciência por não poder ler, por mim mesma, o que precisava, tantas vezes quantas desejasse. Miss Sullivam estava sempre ao meu lado, não apenas lendo livros, mas repetindo as aulas na minha mão, ou procurando palavras nos dicionários de Latim, Alemão e Francês. Não estava familiarizada com nenhuma dessas línguas. Até hoje fico pasmada, pensando como, com sua vista tão curta, pôde ela levar a cabo trabalho tão árduo (KELLER, 1953, p. 25).

Freud adjetivou falhos os atos psíquicos inconscientes em que o desejo recalcado retorna, manifestando-se por escape, geralmente de modo perturbador, uma vez que o eu tido

\footnotetext{
${ }^{94}$ Libido: "Energia postulada por Freud como substrato das transformações da pulsão sexual quanto ao objeto (deslocamento dos investimentos), quanto à meta (sublimação, por exemplo) e quanto à fonte da excitação sexual (diversidade das zonas erógenas). O termo "libido" significa em latim vontade, desejo" (LAPLANCHE e PONTALIS, 2001, p. 265-266); "Termos latino (libido=desejo), inicialmente utilizado por Moriz Benedikt e, mais tarde, pelos fundadores da sexologia (Albert Moll e Richard von Krafft-Ebing), para designar uma energia própria do instinto sexual, ou libido sexualis. Sigmund Freud retomou o termo numa acepção inteiramente distinta, para designar a manifestação da pulsão sexual na vida psíquica e, por extensão, a sexualidade humana em geral e a infantil em particular, entendida como causalidade psíquica (neurose), disposição polimorfa (perversão), amor-próprio (narcisismo) e sublimação" (ROUDINESCO ; PLON, 1998, p. 471).
} 
como consciente (moi) não está precavido para tais acontecimentos em meio às ações cotidianas. Que o sujeito possa planejar suas ações, está posto, porém que seja capaz de evitar atos, nem tanto. Por esse motivo, Freud situou o ato falho como uma formação de compromisso entre o consciente e o recalcado, portanto como uma espécie de prova da castração.

Do ponto de vista da psicanálise, o que é um ato? $\mathrm{O}$ ato falho poderia dar disso uma primeira ideia. Quando o sujeito "involuntariamente" quebra um objeto que detesta, o ato "falho" é, de fato, particularmente bem-sucedido, tanto mais que, no caso, o desejo inconsciente vai manifestamente mais longe que as intenções do indivíduo. Porém, sem dúvida, é sobretudo em uma retomada significante que $\mathrm{o}$ ato falho tem valor de ato. Todos podem tropeçar. Porém só haverá ato se o sujeito reconhecer que deu "um passo em falso" (Choula Dorgeuille, in CHEMAMA ; VANDERMERSCH, 2005, p. 45).

E porque atribuir a Sullivan a autoria disso que reconhecemos como um ato educ(a)tivo? Onde estaria esse "passo em falso", se apenas ela fôra capaz de educar a menina, mesmo sem saber exatamente como, fazendo precipitar efeitos expressivos de subjetivação? A resposta, acabamos de dar: ela soube fazer, porque não sabia que sabia que não havia saber sobre o que fazer, então, simplesmente, deixou de fazer o que sabia que não deveria ser feito, mesmo sem o saber. E fez.

Tenho o privilégio de não saber quase tudo.

E isso explica

o resto.

Manoel de Barros (2010, p. 461).

De próprio punho, escreve Sullivan, não sabia ao certo como inventava tudo, mas fato é que dava tento, suas ações pedagógicas e educativas não lhe custavam extensos projetos, nem complexas elucubrações assentadas em teorias de última geração. Seja pelo viés de ações, ou de atos, Sullivan deliberadamente levava a cabo sua empreitada, e nesse aspecto, já dissemos, mostrava-se bastante viril: não se fazia valer de uma equipe multidisciplinar, aplainando o caminho, com médicos e psis de toda especialidade, nem educadores especiais ofertando-lhe métodos e paramentos pedagógicos capazes de estimular da melhor maneira possível os neurônios de Helen. Ela mesma se autorizava a partir de um savoir-faire que invencionava, a partir do Outro, arriscando-se em outros trilhos...

Freud detecta o ato falho igualmente em certos fenômenos psíquicos como: ideias espontâneas - como o chiste e a associação livre -, os sonhos, os atos sintomáticos, acidentais. Muitas vezes eles são acompanhados por "uma multidão de pequenos fenômenos secundários" que põem em jogo o corpo, o 
gestual, a emoção visível num rosto, a impaciência, a repetição do ato falho ou um segundo lapso. $\mathrm{O}$ ato falho não deve em nenhum caso ser decifrado em sua forma, mas na intenção a que serve. (...) vemos que o ato falho tem um papel defensivo em relação a certas representações capazes de perturbar 0 equilíbrio psíquico do sujeito" (KAUFMANN, 1996, p. 55-56).

- ... o ato não deve ser decifrado em sua forma, mas na intenção a que serve... o ato falho tem um papel defensivo em relação a certas representações capazes de perturbar o equilíbrio psíquico do sujeito...

Contudo, se atuava junto a Helen, perguntamo-nos, Anne Sullivan defendia-se do quê?... Sabemos que somente ela poderia responder tal indagação, mas conhecendo um pouco da história da moça, talvez pudéssemos arriscar um palpite selvagem... defendia-se da morte, aquela que alcançou antes do tempo sua mãe, o pequeno irmão e que também poderia servir a ela, encurtando-lhe a vida. Morte real da qual buscou fugir a todo custo, inferimos, inventando modos de subsistir, já que as condições que a receberam em vida não foram das mais promissoras.

A data mais cara para mim, no ano, é a de sua chegada a minha casa pela primeira vez. Ela era uma mulher jovem e só. Cega, desde criança, acabava de recobrar a vista em parte. Junto a mim, tudo lhe era estranho. Estava a 1.500 milhas apartada dos amigos, numa cidadezinha estranha, quase devastada pela guerra civil. Sem outro equipamento que o seu extraordinário espírito e coração animoso, manietada pela visão imperfeita, trazendo apenas o treinamento haurido no relatório do trabalho do Dr. Howe com Laura Bridgman. Sem auxílio, nem conselho, nem qualquer experiência anterior de ensino, ela teve de lutar contra alguns dos mais complicados problemas num dos mais difíceis setores da educação. No seu preparo, havia deficiências e claros que ela própria tinha que preencher com sabedoria. Talvez por causa disso mesmo, ela sabia pôr tanta leveza nos seus ensinamentos (KELLER, 1953, p. 261).

Sigamos com a ajuda dos dicionários, porque a noção de ato também aparece no termo acting-out:

Acting-out: noção criada pelos psicanalistas de língua inglesa e depois retomada tal e qual em francês, para traduzir o que Freud denomina de colocação em prática ou em ato, segundo o verbo alemão agieren. (...) Foi em 1914 que Freud propôs a palavra agieren (pouco corrente em alemão) para designar o mecanismo pelo qual um sujeito põe em prática pulsões, fantasias e desejos (ROUDINESCO ; PLON, 1998, p. 5-6).

- “Agieren”, mecanismo pelo qual um sujeito põe em prática pulsões, fantasias e desejos.

Acting out: Agir dado a decifrar a um outro, principalmente o psicanalista, em um endereçamento, na maioria das vezes, inconsciente; o acting-out deve ser claramente distinguido da passagem ao ato. Para Freud, o agieren tentaria encobrir os atos de um sujeito, tanto dentro como fora da análise. O termo agieren deixa naturalmente pairar uma ambiguidade, pois recobre duas significações: a de mexer, agir, praticar uma ação, e a de reatualizar, na 
transferência, uma ação anterior. Exatamente nesse caso, para Freud, o agieren viria no lugar de uma "rememoração": portanto, agir em vez de se lembrar, de colocar em palavras. $\mathrm{O}$ inglês acting-out respeita essa ambiguidade. De fato, significa tanto representar uma peça, um papel, dar a ver, mostrar, como agir, tomar medidas. (...) Para Lacan, um ato é sempre significante. $\mathrm{O}$ ato sempre inaugura um corte estruturante, que permite a um sujeito se encontrar, no a posteriori, radicalmente transformado, diferente do que era antes desse ato (Choula Emrich, in CHEMAMA ; VANDERMERSCH, 2007, p. 20).

- Agieren: Ambiguidade de significações: mexer, praticar uma ação e também reatualizar, na transferência, uma ação anterior... aquilo que pode vir no lugar de uma "rememoração", ou seja, no lugar da enunciação.... agieren significa, então, tanto dar a ver, mostrar, representar peça ou papel, como tomar medidas... agir...

Ana Lidya Bezerra Santiago, ao discorrer sobre a inibição intelectual em seu doutoramento, escreve um trabalho valioso a quem se volta à educação, especialmente àqueles angustiados com os escorregadios ditos "problemas de aprendizagem". É ela quem oferece a seguinte explicação:

No seminário A Angústia (1962-1963), Lacan desenvolve uma reflexão sobre a função da causa do desejo, situando-a como uma função ligada ao real de um movimento, real de uma ação, seja esta motora ou de outra ordem. Considera que toda ação do sujeito no mundo visa reencontrar o objeto primordial e é animada pela função do desejo. (...) Pode-se dizer (parafraseando Freud, na Interpreção dos Sonhos (1900-19901)) que o ato real, no presente, se modela por um desejo indestrutível à imagem do passado, à imagem de uma experiência de satisfação, que se projeta, no futuro, como realizável (SANTIAGO, 2000, p. 229 e 230).

- ... ato é sempre significante... inaugura um corte estruturante, que permite a um sujeito se encontrar, no a posteriori, radicalmente transformado, diferente do que era antes dele.... Agierem conecta-se, assim, ao Erfahrung de experiência... o ato real, no presente, se modela por um desejo indestrutível à imagem do passado, à imagem de uma experiência de satisfação, que se projeta, no futuro, como realizável...

15 de maio de 1888.

Foi motivo de indagação dos eruditos o modo como logrei ensinar os nomes abstratos a Helen. Tenho para mim que é tão difícil ensinar o concreto quanto o abstrato, porque ambos correspondem a ideias que Helen tem no cérebro, como toda gente. E eu, pobre ignorante, pus-me a ensinar aos homens cultos coisas assim: "Dando-se um doce à criança, espera-se o momento em que ela começa a lamber os lábios e a dar mostra de enorme satisfação com a gustação do doce, para então fazer-lhe na mão a palavra 'doce', que ficará assim eternamente associada à sensação de doçura. Quando se repetir esse conjunto de letras, a criança lembra-se imediatamente daquela sensação e a palavra passa, deste modo, a representar a ideia para ela" (Anne Sullivan, in KELLER, 2001, p. 222-223). 
Segundo Quinet (2001), os quatro discursos determinam formas distintas de ato: o governamental, o educativo (que preferimos substituir por "universitário"), o histérico e o analítico. Cada modalidade de ato caracteriza-se, como vimos, por seu agente: a lei (S1), o saber (S2), o sintoma (\$) e o objeto $a(a)$. Sobre o ato de educar, afirma, este é o tratamento do outro objetivado pelo saber, que pode ocorrer não apenas na sala de aula, uma vez que não é o cenário que define os discursos, nem tampouco as palavras, mas sim o ato. Por exemplo:

O ato histérico é fazer desejar, o que mostra algo que todos vivemos, ou seja, que cortejar, seduzir, atrair, azarar, faz laço social. O ato é sempre histérico quando produz no outro o desejo, inclusive o desejo de saber, e promove a verdade do gozo sexual. $\mathrm{O}$ ato analítico ocorre nesse laço inédito em que são promovidas a desidentificação aos ideais do Outro e a libertação do sujeito do poder mortífero das palavras. (...) $\mathrm{O}$ ato histérico se dirige ao outro como um mestre para estimular seu desejo. $\mathrm{O}$ ato analítico trata o outro como sujeito (QUINET, 2001).

Ou seja, pela via do ato, Anne permitiu esculpir-se como professora e educadora muito além da ação pedagógica ortodoxa, girando nos discursos, inventando para si um existir que acrescentou à cultura, fertilizando de maneira sui generis o campo educacional. Nesse sentido, mostrou-se tão ou mais "cientista" do que muitos teóricos, dando provas de um saber de endereçamento que oscilava entre o mestre, o analista e a histérica. A lógica da hiância subjetiva aparecia em seu trabalho, como ocorre com qualquer professor dado a falar. A diferença é que, talvez, tenha sabido não rechaçá-la, de modo que utilizou-se dessa vazão, impregnando o laço educativo de desejo, não através de um método - não perdia tempo com eles -, mas pela aposta que preferiu fazer em gastar tempo com coisas mais interessantes e prazerosas, como chegou a escrever.

Se o ato educ(a)tivo de Sullivan pôde impregnar em laço verdadeiramente pedagógico-educativo, inferimos, talvez tenha sido pela metatransmissão de sua palavra plena, inconscientemente, no percurso que trilhava junto a Helen, por onde precipitavam pequenas porções de realização de desejos, na jornada em torno do objeto perdido, o pequeno $a$, por onde pende a função do $e d u c(a) d o r$, conforme estamos tentando ilustrar.

- "Mancar"95: tropeçar no hiato? ... .atu(a)ação..?...

\footnotetext{
95 Sobre mancar/claudicar, é com um verso de al-Hariri, que Freud termina "Além do princípio do prazer " (1920), citado também na carta a Fliess de 20 de outubro de 1895: “ Ao que não podemos chegar voando, temos que alcançar mancando... claudicar não é pecado".
} 


\title{
3.1 Sullivan mancava, ou da ferida narcísica do pedagogo ortodoxo
}

\author{
O primeiro livro de Helen Keller, A história de minha vida, foi publicado em 1903
} graças à ajuda editorial de John Albert Macy ${ }^{96}$, com quem Anne Sullivan se casaria dois anos depois. Embora não seja um livro acadêmico, muito menos de qualidades literárias, justifica sua escolha na ancoragem de nossas inflexões por supormos conter enunciações de Helen, Sullivan e do próprio Macy, professor universitário que apresentou a Keller autores como Tolstoi, Anatole France e Karl Marx, entre outros. Ainda que a tradução possa ter ceifado algo desses documentos, o conjunto que compõe o livro mantém uma assinatura, um estilo, principalmente nos escritos de Sullivan, cujo efeito só pode ser causado através de sua leitura. São textos elaborados longe dos matizes da ciência e da literatura, chegando às vezes a resvalar no que poderíamos atribuir a uma escrita de toucador. Se diversos trechos disponibilizados aqui se apresentam um tanto extensos - e isso é uma escolha não muito metodológica, muito menos universitária, sabemos bem -, talvez seja devido à enunciação nem sempre se comportar de maneira frugal, quanto menos dada a resumos e recortes sem que perca nuances de sua verdade.

Mas até que ponto estas fontes são dadas à escuta, ou à validação de referência acadêmica?

Joyce não falou, ele escreveu, e a psicanálise é essencialmente uma praxis fundada na fala. Isso não significa que não se possa tomar textos literários ou não - para análise e/ou como esteio para avanços teóricos, como

\footnotetext{
96 “ A primeira parte do História de Minha Vida (HMV) foi escrita sob a forma de exercícios de composição para aula do Prof. Copeland, no Radcliffe College. Nunca tive ideia de publicá-los e até hoje não sei como o Sr. Bok veio a ter interesse por eles. Só sei que, certa manhã, fui chamada na minha aula de latim, para avistar-me com o Sr. Guilherme Alexandre do Jornal Doméstico das Senhoras. Se bem me lembro, este cavalheiro disse-me que o Sr. Bok queria publicar a $H M V$ em capítulos mensais. (...) falou com tanto otimismo da facilidade com que os exercícios poderiam ser organizados para os capítulos mensais, que eu assinei o contrato para escrever $H M V$ para o Jornal por 3.000 dólares, sem saber bem o que fazia. No momento não pensei em mais nada senão nos 3.000 dólares. Como eram mágicas essas três palavras!...Tudo foi muito bem no começo, porque já tinha um bocado de exercícios feitos e corrigidos pelo professor. (...) Não tardou, porém, o dia em que vi esgotados os temas convenientes (...) não sendo traquejada na colaboração em jornais, não sabia dividir a matéria de acordo com o espaço reservado. Só entrei a sentir o peso do rigor dos prazos para a entrega, quando os telegramas começaram a chegar como bandos de pássaros turbulentos: "Precisamos do capítulo seguinte imediatamente". "Não há ligação entre a página 6 e a 7. Telegrafe o que falta". (...) As cousas iam muito mal, quando a minha amiga Leonore Kinney (...) falou-me de John Macy. Descreveu-me como pessoa de alta inteligência - exatamente o cavaleiro andante de que eu precisava para libertar-me das garras do dilema que me cruciava. Na época, o Sr. Macy era professor de Inglês na Universidade de Harvard. Também dava aulas em Radcliffe, mas eu não o conhecia. Leonore promoveu o nosso encontro. Gostei muito dele; era curioso, inteligente e gentil. Entendeu minhas dificuldades e pôs-se logo a livrar-me delas. Entramos prontamente no exame do material por mim acumulado, ainda num estado de verdadeira nebulosa. Com rapidez e habilidade, ele deu ordem aos pedaços rebeldes. Em poucas horas, fizemos um capítulo coerente, de leitura bem tolerável. Desse dia em diante, o jornal teve os originais a tempo e hora" (KELLER, 1953, p. 21-22).
} 
fez Freud. O Presidente Schreber não foi paciente de Freud, mas foi a análise de seu livro de memórias que permitiu que ele formulasse a noção de delírio como tentativa de cura, fundamental para a teoria da psicose. Lacan, ao fazer de alguns textos literários objeto de suas elucubrações ${ }^{97}$, tomou o cuidado de dizer que não se tratava de uma aplicação da psicanálise à arte, que sempre recusou, mas, inversamente, de uma aplicação da arte à psicanálise, uma vez que o artista sempre precede o psicanalista e lhe abre os caminhos ${ }^{98}$. É nesta perspectiva que retoma Joyce, interessado não em fazer uma análise do conteúdo de sua obra - isto deixa ao cargo de Jacques Aubert, especialista em Joyce, que, a seu convite, faz uma longa intervenção em seu seminário - ou uma psicobiografia do autor, mas em analisar a posição de Joyce em relação à escrita e a à letra.

Neste seminário, Lacan afirma que a escrita o interessa porque, "historicamente, foi por pequenos pedaços de escrita que se penetrou no real, a saber, que se cessou de imaginar. A escrita de letrinhas, letrinhas matemáticas, é isso que sustenta o real" (LACAN, Seminário 23, O Sinthoma, lição de 13/01/1976). À diferença da fala que traz a questão da verdade, do dizer verdadeiro, "quando se escreve pode-se bem tocar no real, mas não no verdadeiro", diz Lacan (Idem, 10/02/1972) (RINALDI, 2006).

O livro é composto de três partes. Na primeira, Keller conta sobre si; na segunda, cartas suas são disponibilizadas ao leitor; na terceira, John Macy faz a apresentação de Helen e Sullivan e, em seguida, oferta ao leitor um apanhado de cartas escritas pela professora às amigas do Instituto Perkins, juntamente com alguns trechos dos relatórios entregues ao Sr. Anagnos, diretor da instituição. Pela verdade que o conjunto deixa transparecer e pela singularidade dessa experiência educativa embora famosa, já quase esquecida, interessou-nos resgatá-la e trazê-la aqui, não por "temperamento de laboratório", mas de biblioteca e escarafuncho.

No início do século XX, era comum que cegos-surdos fossem considerados como idiotas e por isso privados de educação. No corrido de nossa argumentação, não fizemos referência ainda àquela que foi professora de Sullivan, quando esta estudou no Perkins - o que devemos cumprir, uma vez que escolhemos locomotivas e vagões para ilustrar a ideia de elo, de elã, do movimento de ir em busca do outro como pseudópodes, envolvendo e deixando-se envolver, enovelando, novelando histórias.

(...) fico às vezes imaginando o que seria a minha vida se o Dr. Samuel Griedley Howe não tivesse percebido que o espírito imortal de Laura Bridgman não havia sucumbido à supressão dos sentidos. Antes do trabalho do Dr. Howe com Laura, os cegos-surdos como eu, eram considerados idiotas

\footnotetext{
${ }^{97}$ Por exemplo: “A carta roubada" e "Juventude de Gide ou a letra e o desejo" em Escritos (1966).

98 “A única vantagem que um psicanalista tem o direito de tirar de sua posição, ainda que essa lhe tenha sido reconhecida como tal, é a de recordar com Freud que, em sua matéria, o artista sempre o precede, e que não há por que fazer-se psicólogo ali onde o artista lhe trilha o caminho" (Lacan, 1965, p. 8-9).
} 
pela jurisprudência. (...) À primeira vista, minhas experiências pareciam tão paralelas às de Laura, que muitas vezes fomos comparadas. Tínhamos mais ou menos a mesma idade, quando perdemos a vista e o ouvido. Também nos assemelhávamos na circunstância de que, pela extrema bondade de nossos pais e amigos, crescemos ambas irrequietas, voluntariosas e destruidoras, à falta de meios de expressão dos nossos desejos. Foi quando Laura tinha sete anos, que o Dr. Howe veio em seu socorro. Diz ele que encontrou uma criança bemformada, temperamento sanguíneo e nervoso, bela cabeça grande, sadia e ativa. Nas suas cartas, Miss Sullivan descreve-me quase nessas mesmas palavras. Por estranho que pareça, nós ambas tínhamos olhos azuis e cabelos castanho-claro. E eu, também tinha sete anos de idade, ao começar a ser educada. Aqui termina a semelhança, pois fomos educadas de maneira diversa. Aí está um assunto em que gostaria de entrar mais a fundo, mas, é óbvio, não sou eu a pessoa mais indicada para comparar minha própria educação com a de Laura ou de outros cegos-surdos. Deixo a tarefa aos que estão mais livres para falar. Pelo que tenho lido sobre Laura, posso garantir que ela foi viva, curiosa, sendo capaz de superar-me, se tivesse tido a minha professora (KELLER, 1953, p. 190-192).

Laura Bridgman foi a primeira criança cega-surda nos Estados Unidos a ser educada pelo médico Samuel Griedley Howe, embora jamais tenha saído para uma vida fora dos muros do Perkins, como Sullivan observa em uma de suas cartas, quando pretendia encaminhar de forma diferente o futuro de sua aluna, apesar de não ser este o esperado pelo Sr. Michael Anagnos:

O Sr. Anagnos - sucessor do Dr. Howe no Instituto Perkins - esforçou-se por convencer-nos de que eu devia permanecer nesse Instituto, com o que não concordou minha professora, entendendo que o internato me seria prejudicial. Essa mestra sempre foi de opinião que não se deviam arrebanhar num mesmo lugar as crianças defeituosas [sic], mas sempre que possível dar-lhes ambiente normal. Por mim, o Instituto Perkins me teria sido muito agradável, por vários motivos. Além de gostar do Sr. Anagnos como de um pai, e de as crianças aí saberem falar comigo pelas mãos, eu me dava bem no meio de meninas cegas. Ao Sr. Anagnos devo algumas das recordações mais felizes da minha meninice. Acima de tudo, foi ele quem me enviou Miss Sullivan. Diante da insistência da professora em me levar para outros colégios à busca de instrução, aquele bondoso senhor retirou-nos o apoio. Tenho certeza de que se ele ainda vivesse, haveria de ver que Miss Sullivan estava com a razão (Idem, ibidem, p. 69, acréscimo nosso).

Segundo Macy, para chegar à "alma" da criança, Howe apostara na capacidade tátil da menina, prendendo nos objetos cartões com palavras escritas em letras de alto relevo. Tendo a menina conseguido associar palavras e objetos, conta-se que o médico começou, então, a decompor os vocábulos em letras:

O êxito de tais experiências convenceu o cientista de que a criança podia aprender o mecanismo da linguagem escrita, apesar do cérebro estar pior do que o de um bebê, pois crescera sem os influxos do meio ambiente. Em seguida, o diretor mandou que uma professora ensinasse à menina o alfabeto 
manual, que passou logo a ser o meio de comunicação. (...) Mantendo sempre a atitude do verdadeiro cientista, o diretor registrou metodicamente o resultado de seus trabalho, com o espírito de quem labuta num laboratório. Para a ciência, é pena que não se tenha feito idêntico registro do desenvolvimento da Srta Keller. Aliás, isso foi, até certo ponto, determinado pela grande diferença entre Laura e Helen. A primeira foi sempre objeto de estudos de material de laboratório; Helen, ao contrário, com seu rápido desenvolvimento intelectual, impôs logo enormes tarefas às mestras, que tinham de satisfazer-lhes as exigências dos espíritos, ficando, assim, sem tempo para levantar um minucioso relatório do trabalho. A Srta Sullivan sentiu essa falta desde os primeiros anos de contato com a discípula, lamentando-se bastante, pois estava certa de que Helen seria muito mais interessante do que Laura. Além do mais, a Srta Sullivan não possuía temperamento de laboratório. Uma vez vencida a dificuldade, o processo empregado para a vitória perdia, para ela, o interesse ante a satisfação do sucesso e a perspectiva de novos triunfos. Dois outros fatos desviaram a mestra de registrar seu trabalho: sua deficiência de visão para escrever e o mau uso que fizeram de suas primeiras comunicações (John Macy, in, KELLER, 2001, p. 187).

No trecho acima dois registros nos chamam a atenção. Em primeiro lugar, a matriz hegemônica sobre o desenvolvimento psicológico; em segundo, a consideração quase pesarosa sobre o espírito "pouco científico" de Anne Sullivan, por não ter "temperamento de laboratório". No entanto, ao educador, serão mesmo imprescindíveis tais características ou não passam de meras exigências pós-modernas acrescentadas ao rol de habilidades do pedagogo ortodoxo?

- Miss Sullivan, além de quase cega, “mancava”... estava mais para improvisos de Isadora Duncan do que da bailarina-pedagoga-ideal ...

\title{
CIRANDA DA BAILARINA ${ }^{99}$
}

\author{
Procurando bem \\ Todo mundo tem pereba \\ Marca de bexiga ou vacina \\ E tem piriri, tem lombriga, tem ameba \\ Só a bailarina que não tem \\ E não tem coceira \\ Berruga nem frieira \\ Nem falta de maneira \\ Ela não tem \\ Futucando bem \\ Todo mundo tem piolho \\ Ou tem cheiro de creolina
}

\footnotetext{
99 “Ciranda da Bailarina”, música e letra de Edu Lobo e Chico Buarque de Holanda, para o balé O Grande Circo Místico.
} 
Todo mundo tem um irmão meio zarolho

Só a bailarina que não tem

Nem unha encardida

Nem dente com comida

Nem casca de ferida

Ela não tem

Não livra ninguém

Todo mundo tem remela

Quando acorda às seis da matina

Teve escarlatina

Ou tem febre amarela

Só a bailarina é que não tem

Medo de subir, gente

Medo de cair, gente

Medo de vertigem

Quem não tem

Confessando bem

Todo mundo faz pecado

Logo assim que a missa termina

Todo mundo tem um primeiro namorado

Só a bailarina que não tem

Sujo atrás da orelha

Bigode com groselha

Calcinha um pouco velha

Ela não tem

O padre também

Pode até ficar vermelho

Se o vento levanta a batina

Reparando bem, todo mundo tem pentelho

Só a bailarina que não tem

Sala sem mobília

Goteira na vasilha

Problema na família

Quem não tem

Procurando bem

Todo mundo tem pereba

Marca de bexiga ou vacina

E tem piriri, tem lombriga, tem ameba

Só a bailarina que não tem

Justamente, talvez por faltar aptidão para laboratório e ciência, ou melhor, para o discurso universitário, felizmente Annie e Keller, ao contrário de Jean Itard e Victor de Aveyron $^{100}$, puderam triunfar. Ainda que tentasse - e isto é e não é uma suposição -,

${ }^{100}$ Uma análise interessante sobre esse fracasso educativo foi escrito por Lajonquière sob o título "ITARD VICTOR: ou do que não deve ser feito na educação das crianças". In: BANKS-LEITE, L. /; GALVÃO, I. $A$ educação de um selvagem. São Paulo: Cortez, 2000. 
Sullivan não alimentava sua prática educ(a)tiva com a ração anônima, surda, obliterada e insossa do discurso médico-(psico)pedagógico, como fez Itard. Era dada a enrolar palavras em tato, como nos conta uma Keller com 50 anos, provavelmente deixando nas entrelinhas da palma da mão aquele algo a mais que videntes e ouvintes só conseguem captar pelo plus imaterial da prosódia e do olhar.

Os relatos de Miss Sullivan de notícias, paisagens ou costumes eram espontâneos, simples, saborosos, como bombons dourados passados, um a um, para as minhas mãos (KELLER, 1953, p. 43).

$*_{-} *_{-} *$

Em De Piaget a Freud, ao discorrer sobre a ilusão que anima o discurso pedagógico hegemônico, Lajonquière escreve sobre a voracidade da reflexão pedagógica que contribui para traçar a linha divisória entre aquilo que, na área educacional, entende-se por "aprendizagem" e "desenvolvimento":

$\mathrm{Na}$ tentativa desmesurada de alimentar o pragmatismo que há tempos a caracteriza, procura também apoio no discurso da biologia. Isto em absoluto é uma novidade, já que, nos tempos do iluminismo, a pedagogia apelou à medicina e à psiquiatria para poder constituir-se como uma bendita ciência positivista. Desta forma, a (psico)pedagogia e seus profissionais desenham três formas de posturas extremas: 1. Excluem qualquer tipo de intermediação [entre Estímulo e Resposta]; 2. Consideram algum tipo de intermediação psicológica sujeita a controle; e 3. Acreditam que a chave da aprendizagem está dada pela lógica maturacionista do organismo (LAJONQUIÈRE, 1992, p. 16, acréscimos nossos).

Assim, raciocina o autor, quando se pensa em alguma coisa interferindo no fenômeno estímulo-resposta que levam o aluno a patinar no aprender, por exemplo, supõe-se que seja algo bloqueando seu desenvolvimento, o qual, assim que for removido ou transmutado, voltará a operar, possibilitando a retomada da aquisição de conhecimento. Este funcionamento seria compatível com a mônada, indivíduo biologicamente armado de potencialidades que se desenvolvem graças ao processo endógeno de maturação intelectual, afetiva e neurológica do organismo alavancado pelo contato do mesmo com o meio físico, familiar e social, de onde são aportados, ou não, os recursos necessários para que o desenvolvimento se efetive sem maiores desventuras. Outra matriz do pensar hegemônico das aprendizagens, não monádico mas diádico, segundo Lajonquière, ao contrário, supõe 
que nada se interponha entre estímulo-reposta, enfatizando a inter-relação entre indivíduo e sociedade - conforme encontra-se na teorização de Vygotsky. Assim,

(...) como se fossem duas entidades (coisas) pré-constituídas de forma tal que o problema teórico que restaria resolver seria conceitualizar os diversos modos de adequação de ambos termos opostos. Complementação? Superioridade de um sobre o outro? E assim, até o cansaço, sem que por isso se perceba que, colocado o problema teórico em termos de pré-constituição, não pode ele escapar ao destino que cabe à clássica pergunta a respeito da preeminência do ovo ou da galinha (Idem, ibidem, p.17).

Em nota de rodapé, a respeito da dicotomia entre indivíduo e sociedade, cara tanto a Piaget quanto a Vygotsky, Lajonquière esclarece:

(...) o discurso freudo-lacaniano sobre o inconsciente qualifica o dicotômico modelo indivíduo-sociedade como sendo um verdadeiro obstáculo epistemológico que impede pensar a psicanálise como uma "teoria não subjetivista da subjetividade" (M. Pêcheux). É nesse sentido, precisamente, que a psicanálise pode se incluir dentro de uma tradição de pensamento dialético que coloca a pergunta pelos mecanismos de assujeitamento e de constituição do indivíduo como um efeito imaginário-ideológico ao serviço do desconhecimento dos determinantes constitutivos da subjetividade. (...) na medida em que as funções [intelectuais] podem desenvolver-se no tempo cronológico, o sujeito (do desejo) se constitui em relação de continuidade e simultaneidade com o Outro, conforme a articulação lógica da experiência especular e do complexo de Édipo (Idem, ibidem, p.28, acréscimo nosso).

- Por isso perguntávamos qual o tempo para a constituição de um sujeito, porque na medida em que as funções intelectuais podem desenvolver-se no tempo cronológico, o sujeito do desejo se constitui em relação de continuidade e simultaneidade com o Outro, no tempo lógico, conforme a articulação da experiência especular e do complexo de Édipo em reedições... cascas da cebola sendo acopladas ao redor do centro sem semente,quando as coisas saem a contento... quando não, distúrbios globais do desenvolvimento, independentemente da cronologia....

Luciano Elia explicita que sujeito - no sentido de categoria nocional elaborada teoricamente, designada por uma palavra que lhe dá unicidade, precisão e rigor, considerada dentro do corpus teórico da psicanálise como categoria essencial - não deixa de ser um conceito, precisamente lacaniano, pois nem Freud, nem os pós-freudianos utilizaram o termo ao articular os adventos da ciência e do sujeito, como fez Jacques Lacan.

A “ciência moderna", em si um pleonasmo, adverte, resulta de um corte discursivo que rompe com o que se chama episteme antiga. Através deste corte, teríamos passado do mundo fechado ao universo infinito (cf. ELIA, 2007, p. 11), isso que Lacan denomina "mutação 
decisiva que, por intermédio da física, fundou A ciência no sentido moderno, sentido que se postula como absoluto." (LACAN, 1998, p. 869). Até então, a razão de ser das coisas era entendida como a expressão do livre arbítrio divino, assim como de suas intenções.

Esta visão passional apagou-se no decorrer do século XVII. Newton dá o último tiro, como herdeiro dos trabalhos de Copérnico, Kepler e Galileu. (...) a Philosophia naturalis [newtoniana] implica uma matematização radical tanto da natureza, quanto do ato de fazer ciência. Assim, se a natureza possui uma sintaxe matemática, a física deixa de ser uma empresa minuciosa de observação das qualidades sensíveis à maneira do fazer aristotélico. Doravante, na ciência não há mais lugar para as qualidades, os sabores, os aromas, os atos de fala divinos e as melodias; agora é a vez das proporções, das quantidades, das fórmulas, isto é, das letras e dos números. Neste contexto, o cientista já não mais se deixa levar pela observação dos pequenos detalhes; agora ele passa a ter um papel ativo, agora se entrega ao frenesi imaginativo do cálculo. (...) Newton é o ponto de ancoragem da ciência moderna (...) herdeiro e sistematizador de certas ideias astronômico-físicas que vêm se consolidando ao longo do século XVII e que delimitam o que se considera, por oposição aos tempos antigos e medievais, não só a maneira moderna de pensar o mundo, mas também a forma moderna de se fazer ciência (LAJONQUIÈRE, 1994, p. 58, acréscimo nosso).

Se o sujeito que encontra sua primeira formulação no campo da filosofia responde ao gesto de Galileu no campo científico, Descartes, contudo, mantém ainda a imagem de Deus como garantia epistêmica. Segundo Lajonquière, o sujeito cartesiano ou a subjetividade que se articula no frenesi da dúvida se reduz a uma espécie de motor significante,

(...) máquina pensante, ou a um puro topos lógico no "interior" do qual ocorrem permutações de letras e números que geram enunciados da ordem do significado, do imaginário. Um deles, claro está, é o próprio enunciado eu penso, eu duvido, eu estou duvidando... eu sou minha dúvida. Desta forma, ao mesmo tempo em que o cogito é o resíduo de uma operação de esvaziamento imaginário - ou seja, um sujeito escavado pela dúvida, sem a vestimenta das suas representações - ele se pensa - ele acaba "sendo", acaba "ancorando-se" - numa proposição. Em poucas palavras, de um lado temos uma espécie de dúvida descarnada - uma falta radical em ser, um pensar - e do outro um enunciado - um pensamento imaginário. É precisamente neste contexto que Descartes volta a introduzir Deus em cena. (...) Descartes pergunta-se: "como poderia saber que duvido, que desejo, isto é, que me falta algo, e que não sou em absoluto perfeito...?". Na terceira meditação, conclui que tal coisa é possível pela existência da ideia de Deus como um ser soberanamente perfeito. Em resumo, a mão de Deus sustenta a criatura no articular de sua dúvida enquanto ferramenta epistêmica. Assim, a certeza que fundamenta todas as outras é a ideia clara e distinta da existência de um ser perfeito; ou seja, a garantia da certeza, o fundamento do duvidar, a verdade da qual se deduzem as demais verdades, passa a ter a cara de Deus (Idem, ibidem, p.60). 
Entretanto, argumenta Elia (2007, p. 11), é muito diferente pensar que os objetos caem porque o lugar natural do mais pesado é estar em baixo em vez de compreender que, em decorrência de uma força gravitacional, aqueles objetos ficam "em baixo" porque são atraídos pelo corpo cuja massa é muito maior do que a deles.

$-\ldots ? ! \ldots$

O pensamento contorce-se, ou melhor, contorce-se o sujeito do pensamento. Saem feridas as perspectivas sensoriais, perceptivas, das certezas observáveis.

A partir desse abalo, de que se pode estar seguro, afinal? É no ponto de angústia, por assim dizer, desse momento, que Descartes, fazendo da dúvida seu método, responde algo que pode ser enunciado assim: "posso não estar certo de que, ao duvidar de tudo, inclusive do fato de que estou duvidando, continuarei duvidando, e assim, a única certeza que posso ter é a de que duvido" (ELIA, 2007, p. 12).

"A emergência da angústia é a emergência do sujeito" afirma Elia a respeito da aparição do sujeito no momento em que a ciência moderna advém, separada da filosofia. Com o cogito de Descartes, “Cogito, ergo sum” (penso, logo sou), pela primeira vez na filosofia o discurso do saber se volta para o agente do saber, permitindo tomá-lo, ele próprio, como questão, ou seja, colocando em questão o próprio pensar sobre o ser, que se torna assim, pensável. Contudo,

A humanidade precisaria esperar mais de três séculos por Freud e pela psicanálise para dispor de elementos que lhe permitissem entender a relação entre essas duas formas de emergência, a do sujeito e a da angústia, a ponto de poder enunciar que essa relação é de equivalência (Idem, ibidem, p.13, grifo nosso).

A teoria da constituição subjetiva em oposição à maturação é ponto de honra para Lacan, porque prescreve uma negação fundamental: o ser humano em essência não é, mas efetiva uma falta-a-ser ${ }^{101}$.

Um século depois de Descartes, Kant responderia, filosoficamente, ao gesto de Newton:

Em Kant, o sujeito não aparecerá mais como uma res ${ }^{102}$, substância consistente como em Descartes, mas como um Vazio que, no campo do Entendimento, introduz a Razão, momento em que o sujeito é um sujeito transcendental, não-individual nem psicológico, sem que para isso seja

\footnotetext{
${ }^{101}$ Roudinesco e Plon também utilizam falha-a-ser, rever pág. 29, nota de rodapé 20.

${ }^{102}$ Res, em latim, significa coisa.
} 
necessário recorrer à res divina. O sujeito transcendental de Kant se aproxima mais do inconsciente freudiano do que qualquer noção psicológica de indivíduo psicofísico (Idem, ibidem, p.14).

Ainda que um organismo humano possa se desenvolver biologicamente como um relógio, ou melhor, como uma mônada sem janelas, na imagem de Norbert Elias - a ver: crianças denominadas "selvagens" como Victor de Aveyron ou aquelas ditas com "distúrbios globais do desenvolvimento", ainda que não façam uso da palavra, continuam crescendo rumo a puberdades - , um sujeito à linguagem e à palavra não advém a menos que, até determinado momento de sua vida incipiente, ocorra uma perda fundamental, um corte inaugural, a partir do qual terá início a metamorfose constitutiva do infans em sujeito do desejo, esse que a partir da falta, ascende à fala e segue depois na busca, durante sua existência, de reviver a primeira experiência de satisfação, segundo Freud, na tentativa de reencontrar o objeto perdido, segundo Lacan. Satisfação passageira que deixou marcado no corpo e na psique o registro de um primeiro objeto de satisfação que já se foi, deixando em seu lugar, como resto ricocheteado, o furo original resultante do encetamento de uma mãe pela evocação de um pai, ou melhor, de um homem que, em via de interdições, lembra e faz saber: antes de se transmutar em mãe, aquela havia se lançado como mulher, ou melhore, antes da chegada de sua-majestade-o-bebê, já havia falo, desejo, troca sexual. Chamando aquela de volta, racha a célula narcísica mãe-filho, metatransmitindo à criança e à mulher o teor da proibição do incesto, Lei fundante da humanidade, fundante também do inconsciente e, logicamente, do sujeito do desejo, sujeito que é, paradoxalmente, também da ciência e da angústia. Eujemoi escreve:

Esta que não por um acaso chama de Mãe

Antes de sê-lo

Veio ter comigo

Travessou Cortesã

Então desejei

Fazer vir inteira

Abrir flor

Eramesmumamulher

$-\ldots ? ! \ldots$

Sim, permiti quedar-se contigo,

Porque não era para tudo

Nem todo sempre...

Mas, eia! Já é fim

Tens a boca grande 
Em feitio de pequeno jacaré

Porque falo, deseja-me

E como sou mais forte, crescido que tu

Pego de volta a moça, de tudo meu

Para em toda minha

- ...?! ... Simples assim?

Sim! Como meu teu primeiro não:

NÃO!

$-\ldots ? ! \ldots$

Na Conferência XVIII (1917[1916-17]), no final do texto "Fixação em Traumas - O inconsciente", Freud tece comentário sobre a resistência provocada pela teoria psicanalítica, explicando o que ficou conhecido e difundido como ferida narcísica, isso que descreve como o resultado de um golpe sofrido pela megalomania humana:

(...) a resistência contra nós se baseia tão somente na compreensível dificuldade que constitui o inconsciente ou na relativa inacessibilidade das experiências que proporcionam provas do mesmo. A origem dessa resistência, segundo penso, situa-se em algo mais profundo. No transcorrer dos séculos, o ingênuo amor-próprio dos homens teve de submeter-se a dois grandes golpes desferidos pela ciência. O primeiro foi quando souberam que a nossa Terra não era o centro do universo, mas o diminuto fragmento de um sistema cósmico de uma vastidão que mal se pode imaginar. Isto estabelece conexão, em nossas mentes, com o nome de Copérnico, embora algo semelhante já tivesse sido afirmado pela ciência de Alexandria. $\mathrm{O}$ segundo golpe foi dado quando a investigação biológica destruiu o lugar supostamente privilegiado do homem na criação, e provou sua descendência do reino animal e sua inextirpável natureza animal. Esta nova avaliação foi realizada em nossos dias, por Darwin, Wallace e seus predecessores, embora não sem a mais violenta oposição contemporânea. Mas a megalomania humana terá sofrido seu terceiro golpe, o mais violento, a partir da pesquisa psicológica da época atual, que procura provar que o ego não é senhor nem mesmo em sua própria casa, devendo, porém, contentar-se com escassas informações acerca do que acontece inconscientemente em sua mente. Os psicanalistas não foram os primeiros e nem os únicos que fizeram essa invocação à introspecção; todavia, parece ser nosso destino conferir-lhe expressão mais vigorosa e apoiá-la com material empírico que é encontrado em todas as pessoas.

$-\ldots ? ! \ldots$

Se esses são os três golpes que retorceram as certezas do sujeito moderno, voltemos então a tocar na ferida narcísica em campo pedagógico, ligada àquela terceira apontada pelo psicanalista. Não sendo o "eu” senhor em sua própria casa, tampouco um "indivíduo que amadurece naturalmente", crianças e adultos não avançam cognitivamente graças à 
adequação de metodologias de ensino e de aprendizagens ideais. Fosse assim, os sistemas de ensino apostilados ${ }^{103}$, por exemplo, cada vez mais adotados por escolas particulares e públicas do país, psicopedagogicamente tão “adequados" aos níveis cognitivos de cada faixa etária, assim como às diretrizes curriculares produzidas pelo MEC, estariam garantindo alguma melhoria do ensino, o que não parece ocorrer, embora aqueçam o mercado editorial educacional, oferecendo às escolas e professores um produto pré-fabricado, padronizado, capaz de economizar tempo e tutano na elaboração do projeto pedagógico, independente de qual seja o contexto escolar da instituição que os adota - o que não deixa de ser um posicionamento político.

$\mathrm{Na}$ contramão daqueles que postulam como educação ideal aquela que busca coadunar-se ao suposto desenvolvimento cognitivo do aluno, calibrando ações pedagógicas na pretensão de acertar o motor da inteligência, prevenindo e evitando traumas e fissuras no aprender, lembramos que o sujeito é constituído, não de outra forma, a partir deles: "a emergência da angústia é a emergência do sujeito", repetimos Elia. Primeiro vem o "trauma" de suportar a separação da célula mãe-filho alavancada por um terceiro encarnado na função de pai; antes, durante ou depois, vem a "fissura" atordoante da criança, dando-se conta da diferença anatômica entre os sexos, quando o mundo passa a ser imaginariamente dividido entre os que têm e os que não têm pênis. Os dotados, percebendo que outros não são, passam a temer por sua perda; já os que não possuem - como costuma acontecer com bebês aparelhados com vagina - ressentem-se da falta do curioso instrumento até que possam saber que foram dotados de outros bens. Desejo de saber, afinal, por que uns têm e outros não? Como se arranjam os que não têm? O que fazem com aquilo, aqueles que têm? E como conseguir um, se não se tem?.... Fantasmas... Fantasias... teorias sexuais infantis produzidas pelo desejo de saber e pela angústia provocada pela diferença. Todavia, a ortodoxia em campo pedagógico resiste e nada quer saber que o sujeito surge e segue em subjetivações, mesmo em real, é pelo abalo, no exercício de tentar juntar as peças do que não se encaixa direito, de compreeder o que se mantém enigmático, tentando aparar as arestas das certezas cotidianamente estilhaçadas - o que nem sempre é possível, para desconforto principalmente dos que tentam aprender. Traumas e fissuras fazem parte do processo de subjetivação e não há como ser de outra forma, mesmo porque a castração reapresenta-se no frigir inexorável do

\footnotetext{
103 Diferente do livro didático que estampa na capa o nome de seu(s) autor(es) e contém conhecimentos de apenas uma disciplina escolar, as apostilas de "sistemas de ensino" são confeccionadas com a autoria de uma instituição, cuja inspiração parece ter sido a do modelo utilizado por certos cursos pré-vestibulares, compondose de um aglomerado sequencial de material didático, de todas as disciplinas curriculares, organizados por bimestres.
} 
dia a dia, quando as coisas do mundo e da vida, em dinâmica de vicissitudes, insistem em não seguir pelos rumos que o sujeito determina ou projeta. Educar, portanto, é ensi(g)nar a suportar a castração. E dar provas dela, enquanto "adulto". Adulto não-todo.

$\mathrm{Na}$ tela argumentativa do que tentamos formular, eis por onde se encaixa e porque nos interessa a "mancada científica" de Anne Sullivan, esta que não se atinha aos moldes de cientista empírico-positivista, figura que tudo observa, tudo anota, quantifica, qualifica, planeja, desejando controlar a natureza, visando ordens e progressos. Natureza que no caso do sujeito, sequer existe, porque, se há sujeito, só foi porque perdeu-se o instinto e passou a ser desnatural, quando ascendeu à fala e começou a falhar, a duvidar, e esquecer, a atuar, desnaturando-se, virando projétil de ser humano. Natural, já dissemos, é uma galinha, que não erra nas galinhices, nem na emissão do cocoricór.

- Imaginemos a dificuldade que enfrentaria um governo brasileiro caso ousasse propor a retirada da frase estampada na bandeira nacional...

Sim, Sullivan "mancava", dava ombros ao discurso universitário, este que tudo quer saber e produzir para depois lançar à venda o que se transforma em tecnologia capitalista comercializável na educação, na saúde, na moda, na cultura, ou em qualquer outra fatia do mercado, este que é uma draga de quinquilharias tecnocientíficas. Na contramão dos apelos que sofria, fosse por parte da imprensa, fosse pelo instituto Perkins, a educadora "acertava" quando dificultava a exposição da menina para que não a tomassem como objeto de especulação midiática, embora pudesse ter se servido disso, caso o intuito fosse atingir notoriedade e lucro. Na contra-mão, o que lemos nos livros é uma Sullivan contida para falar sobre Helen, embora eloquente para falar com ela, posicionando-se a léguas do discurso universitário cientificista, também do capitalista, alternando, sim, discursos em registros que variavam entre o mestre, a histeria, o analista. Na leitura dos escritos, inferimos, transparece a suspicácia de Sullivan ao que a psicanálise denomina como escuta, essa capacidade hábil de reconhecer o desejo do outro, ressaltando a singularidade de sentidos da palavra enunciada, escutando nos intervalos do silêncio e dos atos falhos. Assim, abria-se. Ofertavase. Conseguia fazer-se entrar. E sair. Entrarsair, entrarsair... e educ(a)va.

De qualquer maneira, a "mancada" de não haver elaborado minuciosos relatórios “científicos" nos conformes solicitados pelo diretor da Perkins atesta que, ao invés de produzir um material para divulgar os feitos extraordinários da aluna egressa de sucesso, que de fato foi, mais importante para aquela professora era implicar-se no que acontecia dia após dia entre ambas e aqueles que estavam por perto. A "mancada", portanto, não era 
defeito nem era acerto, melhor dizendo, excerto de acerto. Quando Anne Sullivan acenava com momentos de indecisão, por exemplo, ao não saber ao certo quais seriam os próximos passos, ao chorar após um enfrentamento mais violento com a aluna, não fazia menos que acenar com a falta, com a hiância do sujeito do desejo, dando provas da castração, reconhecendo-se não-toda, portanto "mancando", ou melhor, tropeçando no hiato. Quando conseguia junto a Helen algo do que havia intencionado, imediatamente passava à diante sem maiores registros nem descrições detalhadas - sua atu $(a)$ ção - , porque o que a locomovia não era a espera pelo resultado de suas certezas, nem a iteração metodológica, mas o caminho incerto que tomava aquilo que propunha à aluna como prática educativa e pedagógica e, consequentemente, tudo o mais que poderia inventar para fazer a menina avançar, se fosse possível.

No filme, diversas cenas mostram a personagem às voltas com suas angústias e limitações. Guardando a reserva das vistas alheias, por exemplo, o espectador assiste a Anne benzer-se antes de "entrar em cena", perguntando-se no que fora que se metera, chorando, dizendo para si mesma que não sabia mais o que fazer, procurando nos dicionários a grafia correta de palavras para ensinar à aluna, tendo pesadelos com o irmão caçula a lhe pedir que tomasse conta dele e não o abandonasse, reconhecendo que, tanto quanto Helen, ela mesma precisava da ajuda de um professor. Nesse sentido, apesar de viril, reconhecia-se nãotoda fálica, o que a marcava como mulher, aberta à precipitação do Desejo-da-Mãe, como adiante intentamos mostrar.

Em uma cena do filme, após ser observada pelo irmão da menina quando estavam ambas na casa, afastadas por alguns dias do convívio familiar, temos o seguinte diálogo:

(...)

- Você não desiste fácil... Como vai fazer?

- E eu sei? Perdi a cabeça e estamos aqui ${ }^{104}$. Estou contando com ela. Ela está louca para saber.

- O quê?

- Qualquer coisa, tudo.

- Talvez ela ensine você (irônico).

- É claro...

- Por que não desiste?

- Porque se desistisse, eu estaria morta.

(...)

\footnotetext{
${ }^{104}$ Foi numa das primeiras aulas ouvidas ainda em tempos da graduação que ouvi o Prof. Lajonquière dizer, para meu absoluto espanto, que não havia como educar uma criança, caso o adulto implicado nesta educação não estivesse disposto a "perder a cabeça" de vez em quando. Confesso que precisei de alguns anos para compreender o que ele transmitiu. De certa forma, este escrito não passa de uma tentativa de colocar em palavras, na forma mais acadêmica que me foi possível, este percurso.
} 
De volta à casa da família, ao receber do pai de Helen o primeiro salário acompanhado de agradecimentos, fala do pouco que conseguira até então, o que a deixava bastante insatisfeita:

- Até agora ensinei a ela uma só coisa: NÃO. Não faça isso, não faça aquilo... - É mais do que conseguimos - responde o pai.

- Eu queria ensinar a Helen a linguagem porque, sem ela, obedecer não é um dom. Obediência sem compreensão é uma cegueira. (...) Não sei mais o que fazer. E continuar o que tenho feito é ter fé que dentro dela isso esteja esperando como água debaixo da terra. O mundo não é fácil, não quero que ela só obedeça. Mas deixar que faça tudo o que quer é uma mentira para ela. Você precisa ficar entre essa mentira e ela - ele, em olhos baixos, concorda. E eu que queria saber do que iria viver, como sobreviveria...

- Você consegue - diz o Sr. Keller, batendo-lhe nos ombros, com um leve sorriso.

- O problema é saber se sobrevivo a isso!? - também sorri...

Charles Melman tem uma fala sobre o impossível na educação que não pudemos evitar. No mesmo evento realizado pela Escola Lacaniana de Psicanálise do Rio de Janeiro, anteriormente citado, alguém da plateia levanta a pergunta sobre qual seria a ação, a função do discurso analítico em relação à educação?

Governar, educar e psicanalisar são impossíveis quando se exercem a partir do discurso do mestre. Qual é o tipo de discurso que poderia torná-los possíveis? Porque é verdade: somos mal governados, mal educados e não somos bem psicanalisados. Então, qual é o tipo de discurso que poderíamos ter para tentar melhorar isto, porque, você tem razão, isto tem relação com o impossível; talvez, se nós começarmos não pelo fim, quer dizer, pelo impossível, para descobrir que há impossível mas, se colocarmos o impossível no começo, quer dizer, que seja registrado na cultura que aquilo que é nosso motor, nossa fonte de energia é o impossível, e que todos os meios que tomemos para tentar curar este impossível custam muito caro, de um modo ou de outro. Talvez [se] começarmos na cultura a sermos capazes de reconhecer o que a psicanálise vem esclarecer, mostrar, talvez isto modifique nosso modo de fazer, que é sempre o de tentar curar, suturar este impossível. (...) para governar, educar e psicanalisar é preciso começar por saber o que é o discurso do mestre, e é preciso também saber o que é o discurso do psicanalista. Penso que vocês conhecem a escrita absolutamente notável que Lacan deu do discurso capitalista, é formidável! É a partir daí que precisamos nos colocar a questão: o que podemos fazer? (MELMAN, 2001, p. 64-65, acréscimo e grifos nossos).

Ao que indica a história contada nos livros, Anne Sullivan dava-se ao enfrentamento com o impossível desde que nascera, e talvez por isso estivesse viva, ainda, exercendo agora um trabalho que dignificava sua ex-istência. Ninguém a ensinou, ela recriou e aprendeu para 
fazer, das tripas, coração. Numa das primeiras cenas do filme, depois de ter sido trancada por Helen em um quarto e acabar descobrindo o esconderijo em que a menina pusera a chave, fala-lhe ao pé do ouvido, mesmo sabendo que não poderia ser ouvida, mas talvez escutada: "Pensa que vai se livrar de mim, não é? ... Não tenho outra coisa a fazer, nem aonde ir...". Sr. Anagnos havia avisado-lhe antes que subisse ao trem para Tuscúmbia: "Lá será difícil”, ao que a moça responde, de pronto, por de trás de seus óculos escuros e olhos recém-operados, lacrimejantes: "Sempre foi!".

- "Dificil? Muito. Impossivel? Talvez. Mas reconhecer o impossivel que nos organiza é uma de nossas responsabilidades” (PEREIRA, 2007, p. 25).

Em suma, a "mancada" da aprendiz de professora, parece-nos, era manter aberta a fissura subjetiva em que se instala o pequeno $a$, por onde se pendura o fio simbólico capaz de enlaçar educadora e aluna, tal qual não foi possível entre o científico-pedagogo-civilizadorobturado, Dr. Itard, e o infans Victor, nomeado desde o início "selvagem de Aveyron".

Caso a função do educador possa mesmo estar sustentada pela imaterialidade do pequeno $a$, como propomos escancarar, não é de espantar que provoque angústia e aversão nosso questionamento a respeito da imprescindibilidade dos métodos de ensino, pois o que fazemos é colocar em xeque a ortodoxia pedagógica, cutucando a ferida narcísica nos campos da educação, já que a respeito disso o discurso universitário mantém a infantilidade de nada querer saber, como faz o obsessivo a respeito da perda do objeto $a$, que ele denega ${ }^{105}$.

O fantasma, vocês conhecem a fórmula tal como Lacan a escreve: $\mathrm{S} / \diamond a$. Quer dizer que o sujeito, enquanto sujeito do inconsciente, não existe. Só existe quando há a perda desse objeto pequeno $a$. A condição de existência do sujeito é a organização, na cadeia escrita, de um corte, uma letra que cai e dá lugar à existência de um sujeito. E se não houver esta queda do objeto $a$, não haverá na cadeia nenhum lugar para que possa existir um sujeito. No caso do obsessivo, este objeto $a$, ele não quer largá-lo, não quer se separar dele. Como eu dizia há pouco, ele é um constipado e retém este objeto $a$. Ao mesmo tempo, ele forclui a existência do sujeito. Portanto, ao mesmo tempo, realiza sua ausência como sujeito. (MELMAN, 2004, p. 109).

Ao ortodoxo/obsessivo é menos angustiante que a Terra mantenha-se plana, no centro do Universo restrito ao Sistema Solar, de preferência em formato de chapéu de mulher, como provocou Lacan, do que a ver-se com a castração, gerada pela renúncia, pela perda primeira

\footnotetext{
${ }^{105}$ Denegação: termo proposto por Sigmund Freud para caracterizar um mecanismo de defesa através do qual o sujeito exprime negativamente um desejo ou uma ideia cuja presença ou existência ele recalca (ROUDINESCO \& PLON, 1998, p. 145).
} 
do objeto $a$. Vejamos a comparação de Melman sobre a questão do desejo insatisfeito na histérica e do desejo impossível de satisfazer, no obsessivo:

\begin{abstract}
Desejo que permanece insatisfeito na histérica, isso acho que a gente compreende bem. Se a histérica quer ficar insatisfeita é justamente porque o que ela queria era a castração que viria fundar seu desejo próprio e não ser sempre tributária, ser um eco em resposta ao desejo dos outros e dever gozar segundo o gozo dos outros, inclusive pela questão do gozo parcial. (...) A questão do desejo impossível de ser satisfeito para o obsessivo é que, no momento em que ele atinge o objeto pequeno $a$, o sujeito se eclipsa, o sujeito desaparece porque o sujeito enquanto tal só existe enquanto permanece à distância do objeto pequeno $a$; o que faz que o sujeito morra no momento em que atinge seu objeto. (Idem, ibidem, p.123).
\end{abstract}

O problema é que quem paga pela denegação da castração no exercício pedagógico não é só o pedagogo, mas principalmente o selvagem de Aveyron, por exemplo ou, atualmente, o exército dos com "déficit de atenção", dos "hiperativos", dos "disléxicos", dos com "síndrome do pânico escolar", e de quem mais for capturado nas redes discursivas paraeducadoras dos diagnósticos à manga da pós-modernidade científica em campos interdisciplinares da educação e da medicina alopática. Em relação a esta denegação,

Poderíamos dizer que o que dá o estilo da relação do obsessivo a outrem é, precisamente, apresentar-se sempre como se se anulasse, se apagasse, como se ele deixasse a força, a virilidade ao outro, mas também como se fosse sua própria discrição, seu próprio apagamento a condição da virilidade do outro, ao mesmo tempo que tem todo este voto de morte ao lugar do outro para poder vir, enfim, a este lugar (Idem, ibidem, p. 118).

Neste ponto, novavelha cena retorna do recalcado, "pedindo" para ser re-escrita: Defesa da monografia supracitada, final de 2005. Profa. Denice Catani, titular da Faculdade de Educação da Universidade de São Paulo, a quem tanto agradecemos pelas observações rigorosas ao nosso trabalho durante a banca avaliadora do mesmo, depois de tecer com generosidade comentários elogiosos a respeito da escrita, e do estilo, dizendo que lhe havia lembrado os ensaios de Montaigne, pergunta sem rodeios: Ana Carolina, você questiona os métodos de ensino, diz que educar não é uma questão metodológica, mas no lugar, põe/propõe o quê?

Mal-estar no auditório composto por familiares, colegas da graduação, uma ou outro estudante de pedagogia. Acompanhada como sempre de Je e Moi, na procura de uma fala em resposta, começamos a tentar responder, porque a resposta não estava pronta para vir imediata, pois não havíamos pensado exatamente nesses termos e no entanto, instâncias internas cutucavam as entranhas: 
- O quarto capitulo! Está lá, o início da resposta, "Se a educação não for uma questão de método...", com alguns itens e subitens que procuravam desdobrar “...questão de quê??"; a resposta começara a ser dada, imaginávamos, mas talvez não de modo suficiente: "...Em contraponto às metodologias do ensino, modos de endereçamento, estética, estilo", sem dizer do "Drops em prosa, Roseano: Mire veja - olhe”...

Confusão mental, perdição aparente. Sideração. Estado de suspensão da fala, imagino também do olhar. Sangue esquentando o rosto, transpirando mãos. Amolecimento dos braços, pernas, palpitação. Piaget estivesse por dentro, na observação empírica de eujemoi, diria:

- Eis um exemplo universitário de desequilíbrio cognitivo, em tentativas de equilibração majorante...

Certamente era o que ocorria, como vem acontecendo, aliás, antes mesmo da pesquisa para esta dissertação, quando a seleção de material bibliográfico, sem saber-sabendo, já havia começado, como pudemos constatar après coup. Isto que Ana Carolina no set da análise clínica, em tom de brincadeira, costumou nomear a Cabeça - espécie de personagem imaginada para o conjunto disjunto de eujemoi - , vem há tempos por iniciativa subjetiva, ou melhor, por força pulsional, nos parece, construindo representações, escolhendo imagens, procurando textos, assistindo a filmes, catalogando cenas do que acontece na clínica do aprender junto aos alunos em transferência e contra-transferência, numa constante tentativa não propriamente consciente, de tentar juntar peças até então desconexas, desencaixadas, acerca do que precipita da atividade educativo-pedagógica em que se lança e da qual não sinaliza querer emigrar até que consiga compreender e ofertar à cultura, e a si mesma, uma espécie de bricolagem do que retrata poder ser a função de educador. No trabalho de pôr-se em fala com o outro e para o outro, durante anos, por ventura-talvez Dona Cabeça tenha se habituado ao prazer de experimentar o céu aberto de um tipo de giro automotor não propriamente circular, mas fractal, em costuras de retalhos recolhidos na estranha arte de ensi $(\mathrm{g})$ nar...

- A Cultura! ...?!...

Pelo que me lembro, ou reinvento, foi essa a resposta dada à respeitada professora, porque a memória falha, também manca, mas nada em seu lugar apresenta-se com outro quantum de verdade, ainda que uma vez imaginária. Historicizamos:

- ...?!... Cultura em geral... Formação com mais consistência para o professor, no lugar dos métodos de ensino. Que o professor aprenda sobre o ensino da Matemática, das 
línguas, da Biologia e da Botânica; que aprenda por vários ângulos, modos e trejeitos, por exemplo, a Geometria que deverá ensinar, a Geografia que deverá passar, a parte da História da humanidade que deverá contar; que o professor aprenda não só a ler, mas principalmente a escrever na graça difícil das palavras do português; ou então, por prazer, jogue-se a investigar os mistérios dos celerados, das baleias, do Teorema de Pitágoras; do sentido das equações do segundo grau e da variedade e história dos símbolos matemáticos $^{106}$; dos labirintos da sintaxe em conexão com as classes gramaticais; do ritmo e da sonoridade na conjugação dos verbos; que se demore um pouco na beleza de um número irracional e pelo menos sinta, como lembrou Sara Paín ${ }^{107}$, o mistério do infinito que ele propõe; que se debruce por um tempo a pensar nos compassos e descompassos da globalização; ou na nanotecnologia; no rolar de cabeças da Revolução Francesa e nos ideais iluministas que não se realizaram até hoje; na voracidade cruel do capitalismo; que se perca e se reconheça, se puder, na beleza e na tristeza dos grandes poetas e prosadores, senão universais, pelo menos da literatura brasileira, que tem livros tão belos e já dão um bom começo; que se pergunte o porquê das línguas mortas; das vertentes dos movimentos artísticos da pintura, da música, da literatura; que se interesse pela incrível história do teatro e, por que não da própria Pedagogia? Enfim, que se intere de algumas palhetas do todotudo que compõe no Outro a Cultura de uma civilização, senão de várias, para além das disciplinas escolares, talvez tentar entender o porquê de serem estas e não outras, ainda, as eleitas para compor e formatar o currículo escolar...

Ainda que a vontade mais íntima de verdade-verdadeira era em nada não ter respondido nada, deixado o furo ali, só furado mesmo, embora desejasse vomitar o que talvez viesse em rompante deseducado, para a ocasião, justamente à professora que, com elegância e delicadeza, sob a voz doce e calma que lhe é particular, através de sua justa pergunta permitiu-nos escrever, tanto tempo depois, o que vem a seguir, em regurgito nada universitário:

- Sei lá eujemoi!, sabe-se lá o que será posto no lugar dos métodos de ensino?, pedagogos não-ortodoxos na formação de outros não-ortodoxos é que deverão escolher, elencar, dedilhar o que parece importante, isso que é uma estrada longa e prazerosa para se tomar. Porque apontar um buraco, uma falha, não quer dizer "Olha, tenho aqui na minha maleta de caixeiro viajante um produto que deixa o ovo em pé...”, não!. Só estou aqui apontando um buraco, um pequeno e escuro buraco... Que mal pode haver termos que nos haver, vez por outra, com os buracos? (Essa parte é para ser escrita só no final, quando estivermos às voltas com a Origem do Mundo, Ana Carolina ... ai ai ai, por que a Cabeça insiste em pensar fora de ordem?, fora dos métodos, aos borbotões?..., você, eujemoi, está em meio à escrita dissertativa, não pode se controlar?...Sim, poder posso, quase aprendi na

\footnotetext{
${ }^{106}$ Por exemplo, quem inventou o sinal para substituir o conjunto de palavra é igual a, o senhor sabe? Pois foi um matemático inglês, Robert Recorde, argumentando que nunca vira na vida coisas mais parecidas do que duas retas paralelas. Então, indicou em suas obras que duas quantidades são iguais da seguinte forma:

$8======6+2 ; 24: 6========2.2$ Então, os matemáticos logo passaram a utilizar esse sinal, mas de um modo simplificado, mais curto: $8=6+2 ; 24: 6=4$. (cf. BOYER,C. B. História da Matemática. São Paulo: Edgard Blucher Ltda, 1974)

107 "Conversando com Sara Paín”, in Estilos da Clínica, ano1, número 1: Dossiê Psicoses e Instituição. IPUSP, São Paulo, 1996.
} 
escola - responde o coro subjetivo -, mas dá licença de arriscar e também nos autorizar a não querer nos comportar tão nos conformes, descruzando as pernas como uma boa moça?).

Se apontamos o buraco - retomando - , foi só para dizer, aos pés de Guimarães Rosa, na companhia dos textos freudolacanianos, que "mirem-vejam-olhem": educar fosse uma questão de método a coisa toda seria tão mais simples, tãotão mais fácil, tãotãotão mais sem graça, também... e já que não se pode mais dormir em paz porque a ilusão está sendo tirada debaixo dos pés, bom, aí, quem sabe, para tentar alinhavar esse buraco, já que obturá-lo seria mesmomesmo impossível - porque é estrutural ao sujeito, repetimos - bem, se for admissível ao menos tentar alinhavá-lo, talvez, possamos aceitar como fio invisível esse objeto pouco provável em utilidades, a não ser para fazer pensar sobre o impossível e nos pôr a estudar um pouco mais... o que vai no lugar dos métodos de ensino, talvez seja mesmo aquele pequeno $a^{108} \ldots$

- Pronto, um objeto!, porque se há buraco, há de haver um objeto, pois como poderia haver bainha, não fosse pela espada... e vice-versa?

$-\ldots ? ! \ldots$

\subsection{Em nome da ciência moderna, o esvaziamento do estofo ${ }^{109}$ educativo}

A professora não era coerente. No entanto, foi a única mulher que eu conheci intimamente capaz de se entregar às asperezas de uma discussão e sair vitoriosa. Era preciso cautela com suas impetuosas réplicas quando falava

\footnotetext{
${ }^{108}$ Pequeno a: "Termo introduzido por Lacan, em 1960, para designar o objeto desejado pelo sujeito e que se furta a ele a ponto de ser não-representado, ou de se tornar um "resto" não simbolizável. Nessas condições, ele aparece como uma "falha-a-ser", ou então de forma fragmentada, através de quatro objetos parciais desligados do corpo: o seio, objeto de sucção, as fezes (matéria fecal), objeto de excreção, e a voz e o olhar, objetos do próprio desejo." (ROUDINESCO ; PLON, 1998, p. 551). "Freud conduziu a questão do objeto na psicanálise à de um objeto perdido em jogo na repetição, e Lacan acrescentou a isso a questão do traço que inscreve a repetição. (...) o objeto perdido na repetição leva também à questão do ato em que ele pode estar em jogo" (KAUFMANN, 1996, p. 377). Ver nota de rodapé n. 17, pág. 26.
}

109 Estofo: Termo retomado de Lacan para a metáfora do ponto capitonê (point de capiton) ao ponto de basta, o que na linguagem se faz representar pela pontuação, produzindo sentido pela retroação. Capitonner, em português, traduz-se por acolchoar, estofar, sendo o ponto capitonê aquele que une as duas faces de um estofado, geralmente com botões costurados de forma geométrica, em intervalos regulares, dando firmeza e acabamento estético à estrutura. "Novas formas de enlace, sem o apoio do Nome-do-Pai, podem funcionar como ponto de capitonê, sustentando a estabilização e a construção de laços com o Outro", in MONTEIRO, Cleide Pereira; QUEIROZ, Edilene Freire de. A clínica psicanalítica das psicoses em instituições de saúde mental.

Psicol. clin., Rio de Janeiro, v. 18, n. 1, 2006 . Disponível em:

$<$ http://www.scielo.br/scielo.php?script=sci_arttext\&pid=S0103-56652006000100009\&lng=en\&nrm=iso $>$. access on 15 Dec. 2010. doi: 10.1590/S0103-56652006000100009. Acesso em 15/12/2010. 
com demasiada firmeza ou entusiasmo em favor disto ou daquilo. Aborreciase com o lugar-comum em qualquer assunto: educação, política, religião ou qualquer outra esfera de intercâmbio social. Uma conversa arrastada sobre Ciência ou Filosofia era um suplício para seus nervos, mas a palestra agradável de um Mark Twain ou de um Dr. Alexandre Graham Bell prendialhe a atenção sobre um tema profundo, durante um tempo suficiente para fazêla sentir-se arejada e inspirada. Detestava a retórica, mas era sensível a qualquer expressão das faculdades superiores de outrem. Eu procurava não discutir com ela - e poucas vezes o conseguia - pois sabia que ela me faria ficar confusa e sem argumentos, principalmente quando ela estava zangada ou com a imaginação inflamada. Os seus comentários brotavam espontaneamente, de modo convincente e incisivo, deixando-me "ofuscada, encantada e muda ao mesmo tempo". Não falava como um poeta, exceto quando descrevia para mim as belezas arrebatadoras da Natureza, mas secretamente anotava fragmentos de poesia, à medida que estes lhe ocorriam. (p.79) (...) Um dia ela me disse: "De vez em quando mudo as minhas teorias sobre a vida e isto mantém o tédio à distância". Ela não era coerente, como já declarei, e não compreendia que afastar de si, impulsivamente, as suas próprias conclusões era como desenterrar sementes para ver se estão germinando. Suponho que a sua ideia era de que todos os dias perdemos algo de nós mesmos. As nossas ilusões se desfazem, os nossos ideais mudam, as amizades se dissipam e tudo aquilo que nos é familiar como que escorre por entre os nossos dedos. Tornamo-nos estranhos ao eu que viveu como se não fosse nós próprios. Contudo, o que a protegeu contra os conceitos desprovidos de sensação foi o seu inextinguível amor pela beleza exterior, e contra as sensações desprovidas de conceitos, foram a vontade dominadora, a pertinaz recordação da sua infância e adolescência e das personagens e incidentes em torno dos quais se centralizou a sua vida, naquela época. (KELLER, 1959, p. 94-95).

Em Um mundo sem limites: ensaio para uma clínica psicanalítica do social (Companhia de Freud, 2004), Jean Pierre Lebrun põe-se a pensar o contexto de um mundo construído sobre os implícitos do discurso da ciência, destacando uma série de traços que marcam e constituem o social no qual funcionamos. Entre as características estão: 1) perda do bom senso, saber interno ao sujeito que não precisa de conhecimentos exteriores para funcionar como uma espécie de bússola resultante da instalação da ordem simbólica humana a nos dar o sentido de limite; 2) supervalorização da eficácia via tecnicização, cujo objetivo é o domínio do real, introduzindo no real como impossível um novo possível, confundindo querer o impossível com o tornar tudo possível; 3) supremacia da binaridade, ou tudo ou nada, origem da dificuldade que temos em encontrar nuances, em poder determinar responsabilidades compartilhadas, desaparecendo, assim, a possibilidade do discernimento da dialetização possível dos contraditórios; 4) prevalência da servidão voluntária com relação a enunciados acéfalos, que se apresentam como se nada mais devessem à enunciação, cujo efeito é promover o saber da última moda, prescindindo de reter o trajeto histórico que foi necessário para chegar a tais produções, estas que acabam por ser 
transformadas em enunciados para o consumo e a repetição nos discursos universitário e capitalista; 5) saber o que é bom para todos, ditando em nome do científico, o que é válido e universalizante; 6) recusa de reconhecer uma ausência de sentido ao sentido da existência, justamente o que nos dá a condição de encarar a tarefa árdua de inventar um sentido para viver enquanto homem moderno afastado de respostas oferecidas pela religião; 7) atolamento no imaginário pela predominância do registro visual e do simbólico virtual em detrimento da atualização da ordem simbólica, esta que remete à fala, à palavra que, por funcionar na estrutura da linguagem, impõe perda, inadequação da palavra à coisa, exigindo do sujeito um trabalho de simbolização para poder transformá-la em uma falta que deixe a desejar, ratificando a indisponibilidade do objeto e o encontro com a alteridade; 8) evitamento, apagamento da diferença dos lugares estruturais em defesa da simetria, da mesmidade, em ultima instância, a foraclusão do falo, rechaço do mal-entendido, da disparidade, da alteridade, da dissimetria, de forma que os sujeitos passam a ser como se fossem iguais, por onde torna-se imaginariamente possível a "relação"; e 9) dispositivo tecnocientífico fazendo crer que o objeto pulsional pode ser alcançado, efetivando, assim, a pulsão de morte, esta que em verdade é pulsão incestuosa, denominada também, pelo autor, como pulsão de homeostase ou de imobilidade, semelhante ao torpor de uma pulsão que fecha o sistema sobre si mesmo e engaja numa dinâmica que é a da entropia.

É nisso que ela $\left[a\right.$ pulsão de morte $\left.{ }^{110}\right]$ está em estreita conivência com o tecnocientífico. Ao deixar crer numa possível realização pulsional, a tecnociência se torna cúmplice da pulsão de morte e é essa cumplicidade que o simbólico não desarma mais, acarretando a confusão de renunciar a seu desejo e renunciar a gozar do objeto primordial do desejo (LEBRUN, 2001, p. 125126, acréscimo nosso).

Lebrun neste trabalho, procura esclarecer o "mal-estar na civilização" atual identificando em nosso social marcado pelos implícitos do discurso tecnocientífico a secreta adesão a "um mundo sem limite", este que termina autorizando a contravenção da Lei da linguagem, a mesma que nos especifica enquanto humanos. O desabono da função paterna, a

\footnotetext{
${ }^{110}$ Pulsão de morte: “Quanto mais Freud avança em sua obra, mais considera a noção de pulsão de morte, indispensável à psicanálise, chegando a constituir quase toda sua base conceitual. Em particular, julga que ela é a base do princípio primordial de funcionamento do aparelho psíquico. Este último repousa na tarefa - jamais concluída, sempre recomeçada - que consiste em reduzir a excitação e, portanto, a tensão do organismo ao menor nível possível. À primeira vista, é a busca da satisfação - o princípio do prazer - que submete o sujeito pela descarga pulsional, a esse ponto de estiagem. Porém, Freud também viu nisso, fundamentalmente, a expressão da pulsão de morte, pois esse retorno ao ponto de partida, ao nível mínimo de excitação, de alguma forma, é o eco da tendência que leva o organismo a retornar às origens, a seu estado primordial de não-vida, isto é, de morte" (Brigitte Balbure, in CHEMAMA ; VANDERMERSCH, 2007, p. 324).
} 
infiltração por um simbólico virtual, o abalo da responsabilidade e da desinscrição da referência, além das consequências que o fascínio pelo método científico impõe, tudo isso acaba compondo mecanismos que operam na sociedade atual, resultando numa série de sintomas a exigir de nós posicionamento ético e político frente a isto que mais parece uma recusa em assumir as consequências do fato de ser falante (cf. Idem, ibidem: p. 20). As "novas patologias da alma" - toxicomanias, os estados ditos limites ou a colocação do corpo em jogo - , acrescidas de fatos sociais constatados - como a multiplicação de seitas, o recrudescimento da transgressão dos interditos do incesto e do assassinato, ou ainda, a exclusão social - diriam respeito exatamente

(...) à possibilidade específica que um social subvertido pelo desenvolvimento da ciência proporciona ao sujeito: "aproveitar" implícitos promovidos pelo discurso tecnocientífico para aí encontrar o álibi para contravir as leis da linguagem e as implicações do que falar quer dizer (Idem, ibidem, p.21).

Imediatamente nossos pensamentos se voltam ao fracasso escolar apontado por Maria Helena Souza Patto ${ }^{111}$ na década de 90, fracasso já anunciado por Maud Mannoni na década de 70 como sendo uma espécie de resto do funcionamento perverso da educação na produção de um exército de reserva cujos sujeitos são crianças e adolescentes dissonantes ou refratários aos processos educativos. Naquela época, Mannoni já detectava como problemática a presença, no educar, da tecnociência acéfala, anódina, anônima, em sua dimensão política:

Colhidos na armadilha dos sistemas, das técnicas e de um absoluto científico, impotentes para avaliar os nossos conhecimentos em termos relativos, nós mesmos tecemos a teia de uma situação paranoica que dá acesso para as violentas dilacerações de nossa época. (...) Através da recusa (recusa escolar, recusa de se adaptar às normas, recusa de viver), os jovens apontam o que lhes parece intolerável em nosso sistema de valores. (...) A cultura escolar tornouse como que uma parada no jogo das qualificações, das orientações, das seleções políticas e sociais. O jovem recebe-a como um passaporte, um salvoconduto que deve mostrar nos guichês, sem que tenha a sensação de que ela lhe pertence. (...) O rastreamento obrigatório dos chamados distúrbios mentais desde a mais tenra idade cria uma situação em que a escola terá como sequência o hospital. Os desajustados, que são cada vez mais numerosos, devem ser considerados um sintoma da doença das instituições. Numa formação que tem por finalidade exclusiva a produção e a competição e que se representa como propiciadora dos meios da vida, começa-se a discernir que ela impede de viver. (...) A nossa crença na técnica impede-nos de efetuar uma verdadeira mudança pedagógica. (...) $\mathrm{O}$ ensinamento a extrair da Escola de

111 PATTO, M. H. S. A produção do fracasso escolar: histórias de submissão e rebeldia. São Paulo: T.A. Queiroz, 1991. 
Barbiana $^{112}$ é que a sociedade fabrica (e "trata") o fracasso escolar como se tivesse necessidade de um sistema que assegure a produção de uma elite (para profissões nobres) e de serventes para garantir a mão de obra de que a elite a classe dominante - precisa (MANNONI, 1977, p. 48 - 52).

Sobre o histórico da ciência, Lebrun defende que, para chegar ao que conhecemos hoje, a humanidade assistiu a três momentos, sendo o primeiro deles na Grécia do século VI antes de nossa era, quando já se visava uma episteme dedutiva, sob a forma de um discurso que fizesse desaparecer qualquer traço de interlocutividade, a fim de que fosse atingida a objetividade, desembaraçando a ciência da dimensão retórica, utilizando a linguagem como ferramenta para a comunicação de descobertas, começando, assim, a operar a formatação da produção científica de enunciados, excluindo o enunciador como sujeito. No segundo momento, uma vez estabelecido o cogito de Descartes, aquilo que os gregos pretendiam tornase mais próximo do realizável. A ciência passa a se constituir não mais pelas percepções, mas pelas próprias ideias. Graças a Descartes e, antes dele, a Galileu, produziu-se

(...) o nascimento do que Heidegger chamou de "projeto matemático da natureza"; essa ideia que aparece pela primeira vez em 1623, quando Galileu afirma que a natureza é descrita em linguagem matemática. Trata-se, aí, de uma petição de princípio, escolha antecipada de matematização do mundo, de redução da cientificidade das ciências ao horizonte matemático, e é nesse sentido da história que se localiza o caráter decisivo do corte com os gregos que levará a uma outra figura da verdade, aquela que Max Plank resumirá, ao afirmar: "É verdadeiro o que é demonstrável". O procedimentos do Discurso do método [de Descartes] ressoa com aquele do Diálogo sobre os dois maiores sistemas do mundo ${ }^{113}$ e inaugura o da ciência, e, por isso, o da

\footnotetext{
${ }^{112}$ Segundo Maud Mannoni, a Escola de Barbiana foi uma experiência histórica da pedagogia contemporânea a recusar com êxito o mito da infância. Ao minúsculo vilarejo nas montanhas de Vicchio, em Mugello, Itália, um certo padre de nome Dom Lorenzo Milani foi enviado por entrar em discordância com a cúria de Florença. Chegando lá, na própria igreja, formou uma escola de tempo integral para ensinar as crianças rejeitadas pela Educação Nacional porque eram filhos de camponeses e falavam uma língua materna que não a usada nas escolas italianas. Conta Mannoni que lá as crianças eram mergulhadas na leitura de jornais, na contestação dos programas escolares e no estudo oral de línguas vivas; que o trabalho era quase um trabalho de força, mas realizado com entusiasmo; as crianças eram colocadas em posição de ser, simultaneamente, ensinadas e ensinantes, cada uma devendo ajudar outra menos dotada; as que levavam mais tempo para compreender as lições, sentiam-se como as preferidas e eram tratadas como as primeiras da classe - enquanto não tivessem entendido tudo, as outras não avançavam. Não havia recreio, dias de folga, nem mesmo ao domingo - o que não importunava, porque aquelas crianças sabiam que o trabalho na roça era muito mais pesado. 'A escola será sempre melhor que lidar com merda', dito de um professor que certo dia visitara Barbiana, fora gravado sobre a porta da escola, pois ali sabia-se que pelo mundo havia, como ainda há, milhões de pequenos camponeses dispostos a subscrevê-la. Aquelas crianças, conta Maud Mannoni, que teriam permanecido fora do sistema escolar se não fosse a iniciativa de Dom Milani, não só tiveram êxito nos exames nacionais, como se tornaram em grande parte ensinantes revolucionários. Como local de ensino, Barbiana desapareceu com a morte do padre. No entanto, o livro escrito por ele e seus alunos é encontrado com facilidade nos bons sebos do Brasil. Trata-se de livro-manifesto, famoso no final da década de 60, Carta a uma professora: Pelos rapazes de Barbiana, Portugal: Editora Presença, 1982.
}

113 Texto de Galileu Galilei, publicado em 1632, escrito em forma de diálogo entre três personagens, que comparam os modelos astronômicos de Copérnico e Ptolomeu. 
civilização científica, pois o que ela funda é a possibilidade de um saber que não está mais estorvado pela questão da verdade: é um saber sem verdade (LEBRUN, 2001, p. 58, acréscimo nosso).

Então, Lebrun oferece ao leitor a tradução do que Lacan precisa sobre o procedimento de Descartes. Trata-se de um parágrafo do Seminário XII, Problèmes cruciaux pour la psychanalyse (1964-1965), sessão de 10 de junho de 1965, que tomamos a liberdade de transcrever, já que não foi publicado ainda em português:

(...) não é um procedimento de verdade; o que indica, o que constitui sua fecundidade é que, justamente, ele se propôs uma visada, um fim que é o de uma certeza, mas que, no que se refere à verdade, se desencarrega dela no grande Outro, em Deus, para dizer tudo. Não há nenhuma necessidade interna à verdade, a própria verdade de que dois e dois são quatro é a verdade porque Deus quis que assim fosse. É a rejeição da verdade para fora da dialética do sujeito e do saber que é, propriamente falando, o nervo da fecundidade do procedimento cartesiano, pois Descartes pode ainda, durante um certo tempo, conservar, ele, pensador, a golilha ${ }^{114} \mathrm{da}$ segurança tradicional das verdades eternas, elas são assim porque Deus assim quer. No entanto, de certa forma, também se desembaraça dela e, pela via aberta, a ciência entra e progride, constituindo um saber que não tem mais que se embaraçar com seus fundamentos de verdade (...). O procedimento de Descartes não se aguentaria um instante se não houvesse essa enorme acumulação que seguiu o saber, um saber sempre ligado, tomado como que num agarramento ao fato crítico, porque o ponto de partida desse saber está ligado às possibilidades de constituir a verdade; chamarei esse saber de antes de Descartes um estado préacumulativo do saber, a partir de Descartes, o saber, o da ciência, se constitui sob o modo de produção do saber (LEBRUN, 2001, p.59).

Daí em diante, como verdade e saber não estão mais obrigados a, incessantemente, se confrontar poderão enfim ser capitalizados, afirma Lebrun. Trata-se da mutação do discurso do mestre ao do capitalista no qual a inversão dos vetores, conforme vimos anteriormente, faz com que a posição de verdade não seja mais indeterminada e fonte do discurso, mas produzida pelo agente.

O saber pode, doravante, sem colocar em perigo sua validade, "esquecer" a questão da verdade. O procedimento de Descartes implica, pois, um movimento de auto-suficiência que, por não ser estorvado pela dimensão da verdade, pôde se tornar operante. Até então, era preciso retornar à confrontação com a coisa existente como estando na origem do saber, no lugar em que o saber se ancorava na relação com a verdade. É evidente que um tal movimento era paralisante e que foi por dele se liberar que pôde se constituir o saber da ciência moderna. O que constitui a força e a potência do procedimento científico moderno é, pois, haver podido libertar-se de sua

\footnotetext{
114 Golilha: Argola de ferro fixada num poste ou pelourinho, à qual se prendiam criminosos ou escravos pelo pescoço; argola; cabeção com volta engomada; gargantilha de ferro, fixada na antepara de uma coberta, onde se prendia um marinheiro indisciplinado pelo pescoço, mantendo-o de castigo, em pé, por certo tempo.
} 
relação com a verdade da enunciação e, a partir daí, poder se tomar como sua própria origem para progredir (Idem, ibidem, p. 59).

Assim, é conquistada a certeza sobre a qual o saber pode se construir e até ser acumulado, sendo esse movimento duplo de proceder que o homem da ciência moderna enuncia: o de afirmar para logo esquecer que houve enunciação, retendo apenas os enunciados que produziu. Tudo se passa como se desejasse apagar o dizer para só guardar os ditos suscetíveis de serem transmitidos. A partir dessa possibilidade, então, estes se verificam acumuláveis, feito matéria-prima para a ecolalia conceitual.

Nesse movimento, deve ser "esquecido" que o que produziu esse enunciado
foi uma bricolagem, uma confrontação com um real, uma enunciação, um
sujeito. A ciência se encarrega, então, de esquecer o "dizer" para só reter o
"dito". É nesse sentido que o discurso da ciência moderna, inaugurado por
Descartes, é a realização do que já os gregos queriam, quando visavam pela
episteme um discurso esvaziado de qualquer traço de interlocutividade. No
entanto, pelo fato dessa organização, o procedimento da ciência moderna
comporta um implícito maior, a saber, a subversão das relações entre os
registros do Real e do Simbólico (Idem, ibidem , p.60).

Se os gregos tentavam simbolicamente dar conta de um real, tentando compreender racionalmente os fenômenos naturais que observavam, diz Lebrun, evidentemente os poucos meios que tinham e a ausência de um procedimento metodológico aos moldes do cogito faziam que Real e Simbólico estivessem sempre intrincados. Entretanto, o projeto de encontrar na linguagem matemática meios para descrever a natureza permitiu ao cientista, daí em diante, instalar um simbólico que, sozinho, eludindo a enunciação, pretendeu dar conta do real, esquecendo que era exatamente dali que ele partia, conforme fez lembrar Melman sobre a verdade dos enunciados e a dor de existir.

O nascimento da ciência moderna como matemático-experimental supõe, então, a extração de um simbólico, mas ao fazer isso, coloca esse simbólico em posição originária; é o que se repetirá em cada ato do cientista; em cada um dos procedimentos da ciência, tudo o que está implicado no cogito se reproduz (Idem, ibidem, p. 62).

Enfim, depois dos dois momentos da ciência em que Lebrun distingue, primeiramente, o discurso do homem da ciência - aquele da primeira geração em que a enunciação ainda estava presente, embora houvesse votos que desaparecesse - e, em segundo lugar, o discurso científico - o que primava pelo apagamento da enunciação, promovendo apenas a autoridade dos enunciados -, chega-se enfim ao terceiro momento, o do discurso tecnocientífico, cujo neologismo "tecnociência" procura designar a submissão da ciência ao que constitui a essência da técnica, equivalendo dizer que é na realização técnica da ciência que encontramos 
o que a especifica, permitindo daí em diante lidar apenas com enunciados, sem o vestígio do apagamento da enunciação. Diferente do cientificismo (este que o autor identifica como uma doença do segundo momento da ciência, quando a autoridade daquele que se enuncia ainda tem bastante peso para poder objetar à pura e simples submissão aos enunciados), o terceiro momento da ciência alcançado pela humanidade seria este mecanismo que "rola por si mesmo", impondo suas leis, veiculando implicitamente seus pressupostos, alterando tanto o bom senso comum, quanto o sentido de que nem tudo é possível, precisamente, o sentido de limite, o ponto de basta - que desaparece. Porque a tecnociência, daí em diante, promete tornar tudo possível, ao mesmo tempo (lógico) em que esvazia o estofo e afrouxa o laço com o Outro. Os efeitos da elisão de enunciação como modalidade constituinte do laço social pelo qual o saber se sedimenta e torna-se anônimo, afirma Lebrun, são que sua progressão deixa de seguir o cajado do mestre e passa a ser deixada a si mesma, acéfala, auto-engendrando-se, engrenando, por isso, efeitos imprevistos.

Se o discurso da ciência [leia-se universitário] implica, segundo Melman ${ }^{115}$, a foraclusão do Falo, não há nada de surpreendente em que retorne no real, sob a forma de violência desvairada, o que foi foracluído no simbólico. (...) Nossa organização social de hoje, com o colocar em pé de igualdade todos os enunciados, com essa evitação da disparidade entre enunciação e enunciados, induz o apagamento da dissimetria dos lugares e quer apagar as diferenças (...) Apagar a diferença dos lugares, a dos sexos e a das gerações, só tem como efeito embrulhar as referências simbólicas, indispensáveis a nossa vida social; e, com o risco de passar por reacionário, vai ser preciso reassumir o lugar da enunciação e não ceder ao fascínio de um mundo regulado exclusivamente por enunciados. Paradoxalmente, pois, essa obrigação da palavra - que se poderia chamar de dever fálico - é o que constitui a coluna vertebral do laço social. (Idem, ibidem, p.128-129, acréscimo nosso).

Há algum tempo temos questionado a imprescindibilidade dos métodos de ensino para o exercício do educar, este que é um paradigma caro à pedagogia desde a exaltação do método científico surgido no seio da ciência moderna. Paradigma consoante à concepção de mente proposta por Descartes (1596-1650) - o cogito -, que permeia a estrutura da escola moderna, conforme afirma em História da Pedagogia, Franco Cambi (1995, p. 279-311), norteando concepções de ensino-aprendizagem e da ação pedagógica através da elaboração racionalista de currículos e programas com vistas a formar um modelo de homem ideal. Paradigma reforçado pelos estudos da psicologia cognitiva dos anos 50 e substanciado ainda pela pedagogia científica positivista-experimental difundida, entre outros, por Auguste Comte, Maria Montessori e John Dewey, o que teria levando a pedagogia, a partir do século XIX a

\footnotetext{
${ }^{115}$ Charles Melman, "Lecture raisonnée et critique des oeuvres de Freud et de Lacan", seminário 1996-1997, sessão de 10 de outubro de 1996, inédito.
} 
(...) admitir no centro dos problemas educativos a aprendizagem e o desenvolvimento cognitivo, como também as estruturas de uma "teoria da instrução". Tomou corpo, assim, uma nova concepção de pedagogia, pouco atenta aos problemas sociais da educação e muito atenta aos da aprendizagem e da instrução, sobretudo científica. Concepção que se articulou em pesquisas psicopedagógicas sobre a aprendizagem e a construção de linguagem e dos conceitos; em pesquisas de teoria da instrução que se coloca como mediadora entre aprendizagens e ensino, indicando a este os procedimentos mais gerais; em pesquisas didáticas, gerais e especiais, que produziram teorias do currículo, taxonomias dos objetivos escolares de aprendizagem, análises estruturais das diversas didáticas disciplinares, dando vida assim a um processo bastante complexo que mudou radicalmente a concepção da pedagogia nos últimos decênios, especializando-se no sentido científico e técnico (escolar-instrutivo). Os grandes intérpretes dessa virada psicopedagógica foram, sobretudo, Piaget, Vygotsky e Jerome Bruner. (CAMBI, 1995, p. 608-609).

Assim sendo, não é de estranhar que o discurso psico-pedagógico hegemônico defenda e exalte (ainda) o domínio teórico-técnico disto que configura "uma espécie de "fundamento" da nova pedagogia cognitiva" (cf. Idem, ibidem, p. 609). A epistemologia genética, a título de exemplo, parece interessar sobremaneira educadores e agentes formadores certos de que, com esse conhecimento, terão a chave de acesso ao desenvolvimento da inteligência humana, capaz de otimizar e adequar a intervenção pedagógica no desvendamento do exato ensinar e do ideal aprender, ou vice versa, do ideal ensinar e do exato aprender. Lajonquière, desde os anos 90, vem argumentando sobre o quanto esta maneira cientificista de enfrentar o desafio da educação acaba por acarretar a renúncia ao ato genuinamente educativo por parte do adulto, ainda que este o faça sem saber, por voto narcísico, na procura de satisfazer todas as demandas da criança a quem nada supostamente deve faltar - Sua majestade o bebê! ${ }^{116}$ - não apenas na educação informal, mas

\footnotetext{
${ }^{116}$ Freud escreve em Sobre o narcisismo: uma introdução (1914): (...) Se prestarmos atenção à atitude de pais afetuosos para com os filhos, temos de reconhecer que ela é uma revivescência e reprodução de seu próprio narcisismo, que de há muito abandonaram. $\mathrm{O}$ indicador digno de confiança constituído pela supervalorização, que já reconhecemos como um estigma narcisista no caso da escolha objetal, domina, como todos nós sabemos, sua atitude emocional. Assim eles se acham sob a compulsão de atribuir todas as perfeições ao filho - o que uma observação sóbria não permitiria - e de ocultar e esquecer todas as deficiências dele. (Incidentalmente, a negação da sexualidade nas crianças está relacionada a isso.) Além disso, sentem-se inclinados a suspender, em favor da criança, o funcionamento de todas as aquisições culturais que seu próprio narcisismo foi forçado a respeitar, e a renovar em nome dela as reivindicações aos privilégios de há muito por eles próprios abandonados. A criança terá mais divertimentos que seus pais; ela não ficará sujeita às necessidades que eles reconheceram como supremas na vida. A doença, a morte, a renúncia ao prazer, restrições à sua vontade própria não a atingirão; as leis da natureza e da sociedade serão ab-rogadas em seu favor; ela será mais uma vez realmente o centro e o âmago da criação - Sua Majestade o Bebê, como outrora nós mesmos nos imaginávamos. A criança concretizará os sonhos dourados que os pais jamais realizaram — o menino se tornará um grande homem e um herói em lugar do pai, e a menina se casará com um príncipe como compensação para sua mãe. No ponto mais sensível do sistema narcisista, a imortalidade do ego, tão oprimida pela realidade, a segurança é alcançada por meio do refúgio na criança. $\mathrm{O}$ amor dos pais, tão comovedor e no fundo tão infantil, nada mais é senão o narcisismo dos pais renascido, o qual, transformado em amor objetal, inequivocamente revela sua natureza anterior (itálico nosso).
} 
também nos limites da educação escolar, onde a pedagogia científica psicocognitiva opera o educar sob a pretensa legitimidade da ciência.

(...) $\mathrm{O}$ adulto de hoje padece de uma certa propensão a degradar o estatuto simbólico da educação, pois cada vez que se endereça a uma criança, alimentando semelhante ilusão [de que nada lhe falte], acaba fazendo o possível para poupá-la das limitações inerentes à mesma. Mais ainda, é por essa razão que o adulto não pode não experimentar uma espécie de horror ao ato educativo, parafraseando Lacan, visto que as restrições nele embutidas ecoam subjetivamente como uma ferida narcísica. O grau de pertinência suposta ao discurso (psico)pedagógico hegemônico é precisamente proporcional ao tamanho desse horror. Com efeito, a ilusão central em torno da qual esse discurso se articula é aquela de ser possível programar a fabricação de um ser ideal-natural. Na medida dessa crença animada por semelhante voto narcísico, a educação, bem como o cotidiano escolar, passam a estar tencionados conforme um cálculo prospectivo. (...) O adulto não educa em razão de um dever-ser sempre a cumprir que emana do passado, senão em nome da quase certeza futurista embutida em toda teorização metódicopsicológica desenvolvimentista. (...) Assim sendo, o fato de o adulto invocar as previsões, bem como as prescrições inerentes às teorizações metodológicodesenvolvimentistas, acaba esvaziando o ato educativo. (...) Nesse sentido, se o ato educativo articula-se de sorte que recusa o desejo que lhe outorga precisamente sustentação, então a transmissão de saberes e conhecimentos se desgarra. (LAJONQUIĖRE, 1999, p. 191, acréscimo nosso).

Por este viés, talvez os métodos de ensino possam ser tomados não mais como ferramentas imprescindíveis da escola, mas pelo que realmente são ao servirem de instrumental moderno a prometer, no acidentado e fértil terreno de alteridade entre sujeitos professores e alunos, terraplenagem pedagógica para a produção educativa industrial. Se a abordagem metodológica dos conteúdos pedagógicos contribui para o ideário de uma educação ideal $^{117}$, não é senão esvaziando e empobrecendo o estofo imaginário-simbólico pelo qual se articula o ideal de uma educação, este que, pelo avesso do modelo ${ }^{118}$, poderá encontrar sustentação via objeto causa de desejo no (des)encontro com a impossibilidade estrutural no educar, via ato educ(a)tivo, quando um sujeito endereça-se a educandos oferecendo-se para ocupar, com o corpo e a palavra, temporariamente, lugar de identificação não parental, porém de mestre, de professor, de artesão da Cultura, de sujeito suposto saber, a professar convicções e apostas veiculadas por meio da verdade mais recôndita, talvez Real:

\footnotetext{
117 “A Educação Ideal é um mandato imaginário, que pretende ter respostas para tudo, não há espaço para o imprevisto, para a criação, enfim para o desejo, a única possibilidade para aquele que recebe este mandato é ficar no lugar de objeto que completa o Outro mandante. O ideal de uma educação é de ordem simbólica, articula uma demanda que é enigmática, tem proibição, abrindo a possibilidade para o desejo, para o imprevisto, para o improviso, para o surgimento do sujeito" (PETRI, 2003, p. 25).
}

${ }^{118}$ Ver, de Marcelo Ricardo Pereira, O avesso do modelo: Bons professores e a psicanálise. Petrópolis: Vozes, 2003 . 
precipitação de um estilo. Objeto causa do desejo em campos de educ(a)r, pelo qual sustentase o pêndulo da função do educador, a oscilar entre um desejo e um Nome, como tentaremos demonstrar adiante.

Assim, a crença perene na metodologia de ensino, ao que parece, tem a função de suturar a ferida narcísica a fim de diminuir a angústia de quem é convocado, por profissão, a falar com e para alunos e deparar-se, tanto do lado de lá, quando do lado de cá, com o que é estranho, inesperado, difícil de ser contornado - obsceno talvez fosse a palavra certa - em especial, com a indisposição do aluno para o aprender, assim como com a indisposição do adulto para implicar-se no ensi(g)nar. Para quem apreendeu da psicanálise o sentido radical do funcionamento inconsciente, tal crença torna-se oca, desprovida de qualquer esperança, passando a operar em sutil, mas determinante arrefecimento do furor pedagógico que pulsiona o espírito pedagogo. O âmago da questão educ(a)tiva não está posto aí, na maneira mais moderna, científica e adequada de se endereçar ao educando. Caso nos mantivéssemos emplastrados a essa crença, teríamos que voltar, imaginariamente, a renunciar à responsabilidade ao que falar implica, o que, para o bem ou para o mal, por questões de ordem ética e política, já não nos cabe.

Duvido que alguém tenha sido mais investigada que eu, por médicos, psicólogos, fisiologistas e neurologistas. Só sei de duas espécies de testes por que ainda não passei. Até hoje, não fui vivissecada, nem psicanalisada. Para os cientistas, eu sou objeto de análise, como qualquer aerólito, mancha solar ou átomo!... Acho que devo à Divina Providência o não ter sido ainda decomposta em íons e elétrons. (...) Os cientistas, meus algozes, apresentamse munidos dos mais variados aparelhos, com enormes nomes gregos, formas esquisitas e de surpreendente engenho. Como gênios diabólicos, eles cobrem todas as minhas faltas, mesmo as menores idiossincrasias, tudo catalogando, para facilitar depois a tagarelice dos indiscretos de todo o mundo. (...)

Quando os testes começam, a gente tem de arrepanhar toda a coragem, para esperar o assalto de ferrinhos que vêm pousar sobre o corpo. Com precisão mecânica, eles beliscam, espetam, apertam, comprimem, ferroam e zunem. Um aparelho conta a respiração, o outro, a pulsação, o outro toma a temperatura; outro diz se a gente cora, outro indica quando se chora ou se ri; se se sente medo ou se se tem raiva; o que se sente quando se é rodada como grande peão de madeira, ou quando a gente é transformada numa imensa bateria, soltando centelhas divertidas. Resignadamente, a gente entrega os pulsos para serem atados em borrachas, que eles começam a soprar, perguntando: "Está apertando muito, ou não?" - "Oh, não; isso não machuca. Meu braço está quase paralisado!...”

Em seguida, vem a procissão dos testes vibratórios, diapasões, tímpanos, etc. Um irmão gêmeo do aspirador começa a subir pelas costas da gente. É uma orquestra de vibrações do grau $n$ - verdadeiro pandemônio. Depois vem o pequeno Palas-estesiômetro, para medir o número de vibrações que a gente pode perceber.

Então a cabeça da gente é aparafusada num aparelho, e as articulações, movidas com rapidez. Perguntam qual é o dedo, qual é a junta que está sendo 
movida, se move para cima ou para baixo, etc. A gente diz o que vem à cabeça, confiando a verdade ao instrumento.

E os testes continuam horas e horas, ficando a gente sempre com a impressão de que não acreditam nos nossos depoimentos. Há sempre um cochicho monótono, quando fazem a verificação dos resultados, deixando a impressão de que esperavam muito mais de nós. No início dos testes, a gente acredita que vai vencer os que têm vista e ouvido por larga margem. Mas os aparelhos, tal como aquelas crianças de que falamos, dizem a verdade - seu aparelho sensorial restante, em nada difere dos dos outros. Nada de extraordinário, a não ser a própria deficiência. Em vão, procuramos resguardar nossas possibilidades, explicando aos inquisidores que as nossas impressões do mundo não vêm apenas dos sentidos, mas do maravilhoso processo imaginativo e da associação de ideias que entram no nosso espírito aos pedaços, com as nossas experiências físicas caóticas, sincronizadas afinal em conjuntos harmoniosos, que são as concepções do universo.

O que eu gostaria de ver inventado é o aparelho que determine o que se passa no espírito quando se pensa. Embora fale assim com alguma amargura das experimentações que tive de suportar de vez em quando, estou satisfeita pela pequena contribuição que pude dar às pesquisas desse gênero. Entendo que a natureza das impressões sensoriais e dos conceitos delas derivados, bem como os processos que transformam a elaboração mental em palavras, serão um dia fixados com precisão considerável, senão total. Se, ao cabo, esse assunto tão importante receber alguma luz nova no mundo, com as experiências que o Dr. Tilney andou fazendo comigo, dar-me-ei por bem recompensada da perda do tempo e do pequeno sacrifício físico que fiz. Mesmo que isto não se dê, terei sempre lucrado muito, pois com as experiências, fiquei conhecendo o Dr. Tilney (Keller, 1953, p. 199-200).

\subsection{No estilo de educar, o assento do pequeno $a$}

Em Introdução à Psicanálise Lacaniana, conceitos e contextos, para apresentar alguns conceitos fundamentais da teoria, Dunker (2006) discorre sobre a noção de estilo, isto que denomina como uma categoria lacaniana capaz de desconstruir o entendimento psicológico popular do termo, geralmente utilizado como atributo, sinônimo de personalidade ou classe, essência perceptível que diferencia uma pessoa e a faz única, idêntica a si mesma, algo que se deseja possuir ou encontrar no outro, por indicar autenticidade. Tal maneira de entender estilo é oposta à de Lacan, afirma o autor, pois segundo ele, estilo não seria algo que está no sujeito, ou que este possui, mas algo que estaria no objeto a quem o sujeito falante se endereça, daí o estilo ser o homem a quem nos dirigimos, conforme pode-se ler na abertura de Escritos.:

O estilo é o homem; vamos aderir a essa fórmula, somente ao estendê-la: o homem a quem nos endereçamos? Isso seria simplesmente satisfazer a este princípio por nós promovido: na linguagem nossa mensagem nos vem do 
Outro, e para enunciá-lo até o fim: de forma invertida. (E lembremos que esse princípio se aplicou à sua própria enunciação, pois, tendo sido emitido por nós, foi de um outro, interlocutor eminente, que recebeu seu melhor cunho.) (...) É o objeto que responde à pergunta sobre o estilo que formulamos logo de saída. A esse lugar que, para Buffon, era marcado pelo homem, chamamos de queda desse objeto, reveladora por isolá-lo, ao mesmo tempo, como causa do desejo em que o sujeito se eclipsa e como suporte do sujeito entre verdade e saber. Queremos com o percurso que estes textos são os marcos e com o estilo que seu endereçamento impõe, levar o leitor a uma consequência em que ele precise colocar algo de si (LACAN, 1966, p. 9-11).

- Estilo, instrumento de palavra para levar o outro a colocar algo de si...

O que significa me dirigir a vocês?, indaga Dunker (2006). Dirigir-se a alguém significa voltar-se a um outro escolhido para falar-lhe, endereçando-lhe uma demanda, um pedido de atenção, supondo que, além de sabermos a quem estamos nos dirigindo, ainda temos certeza do que estamos enviando enquanto mensagem comunicada. Entretanto, o que ocorre no entre humanos, não é exato, assim...

Quinet (s.d), ao escrever sobre a questão do estilo em psicanálise, também afirma que o estilo é o Outro a quem eu me endereço, ao mesmo tempo lugar de onde recebo minha própria mensagem de forma invertida. Contudo, para esse autor, o Outro pode ser entendido, em duas acepções: como o Outro social que comanda um estilo generalizável não muito longe da moda, ou como o Outro do Inconsciente, sendo este o estilo efetivamente tributário das leis do inconsciente. "Não há forma de estilo, por mais elaborado que seja, em que o inconsciente não abunde" ${ }^{\prime 19}$, por isso a correção de Lacan à frase de Buffon - O estilo é o homem a quem nos endereçamos - , pois Buffon situa o estilo tributário do pequeno outro, enquanto Lacan o articula ao Outro do Inconsciente, de tal forma que a mensagem que o sujeito envia ao outro, ao pequeno outro, é na verdade uma mensagem que lhe vem do inconsciente como discurso do Outro.

O estilo não é o próprio homem. O estilo não é o Outro. O estilo é o objeto $a$, causa de desejo. Se é remeter o estilo ao Outro da linguagem, isto se deve à articulação entre o gozo e o significante. (...) Em psicanálise, a questão de estilo se articula tanto com a verdade quanto com o saber (QUINET, s.d).

Tomado assim, estilo é via da manifestação da verdade, mas não aquela em função do sintoma, senão a que toca o real através do bem-dizer, como pode vir a ocorrer no final de uma análise, quando o Outro que era todo para o sujeito, recebe a condição de também

\footnotetext{
${ }^{119}$ Lacan, 1998 [1966], p. 469.
} 
barrado. Esse ponto de falta no Outro, a barra, seria o correlato topológico do objeto $a$, causa do desejo, que o sujeito encontra no final da análise a partir da travessia da fantasia ${ }^{120}$, uma vez que era esta quem sustentava a suposição da existência do Outro, como afirma o autor. Daí que não se possa antecipar como será o estilo do sujeito no final da análise... pois chegar ao final de uma análise é deparar-se exatamente com isso, com um real bem dito, "\$eu” real bem dito:

A conciliação com o sintoma no final da análise implica, por um lado, não recalcar a verdade do sintoma, mas sim bem dizê-la, e, por outro, habituar-se com seu relato, reduzindo a um caroço ou núcleo irredutível. Mas qual é o efeito dessa redução? Este é um efeito sobre o mal-estar que o sintoma provocava. (...) Em resumo, o bem dizer do sintoma a que leva uma análise conduzida até seu final é a condição de saber lidar com ele, ponto a partir do qual podemos introduzir a questão do estilo (Idem, ibidem, s. d.).

Estilo, portanto, teria a ver com a lida da emergência do real, isso que até certo ponto mantém-se sem significado. Através do estilo, emerge a verdade que não é outra senão a do desejo, que provém do real. A configuração de um estilo, nos parece, precipita da forma como o sujeito implica-se (ou não) no circundar do toro, da falta-a-ser, pela enunciação, esse

(...) o modo de dizer de cada um, o modo de manejar os enunciados e as proposições, aquilo que vem a mais no enunciado por onde circula o mais-degozar, esse suplemento do enunciado. A verdade como tal, por sua estrutura de semi-dizer, que não se encontra toda no dito, participa da enunciação (Idem, ibidem).

\footnotetext{
${ }^{120}$ Fantasia, phantasie (alemão), fantasme (francês), fantasy, phantasy (inglês): Phantasie foi utilizado por Freud, segundo Roudinesco e Plon, primeiro no sentido corrente (fantasia ou imaginação), depois como um conceito, a partir de 1897: “(...) designa a vida imaginária do sujeito e a maneira como este representa para si mesmo sua história ou a história de suas origens: fala-se então de fantasia originária. Em francês, a palavra fantasme foi forjada pelos primeiros tradutores da obra freudiana, num sentido conceitual não relacionado com a palavra [vernácula] fantaisie. Deriva do grego phantasma (aparição, transformada em "fantasma" no latim) e do adjetivo fantasmatique [fantasmático], outrora próximo, por sua significação de fantomatique [fantasmal, fantasmagórico]. (...) De maneira geral, Lacan retoma por sua conta o conceito freudiano de fantasia, mas sublinha desde muito cedo sua função defensiva. Nos seminários dos anos 1956-1957, a fantasia é assimilada ao que ele passa a denominar de "parada na imagem", maneira de impedir o surgimento de um episódio traumático. Imagem cristalizada, modo de defesa contra a castração, a fantasia é descrita por Lacan, entretanto - o que difere fundamentalmente da perspectiva kleiniana - , no âmbito de uma estrutura significante, e, por conseguinte, não pode ser reduzida ao registro do imaginário. Além da diversidade das fantasias de cada sujeito, Lacan postula a existência de uma estrutura teórica geral, a fantasia fundamental, cuja "travessia" pelo paciente assinala a eficácia da análise, materializada num remanejamento das defesas e numa modificação de sua relação com o gozo. Desde a primeira formulação do grafo lacaniano do desejo, em 1957, Lacan elabora um matema daquilo a que denomina a lógica da fantasia. Trata-se de explicar a sujeição originária do sujeito ao Outro, relação traduzida por esta pergunta eternamente sem resposta: "Que queres?" (Che voi?). O matema $\$ \triangleright \nabla a$ exprime a relação genérica e de forma variável, porém nunca simétrica, entre o sujeito do inconsciente, sujeito barrado, dividido pelo significante, que o constitui, e o objeto (pequeno) a" (ROUDINESCO ; PLON, 1998, p. 223 e 225).
} 
O estilo, inferimos - talvez por intuição desmesurada - é o que funciona como uma espécie de invólucro para encaixe do pequeno $a$, dispositivo topológico por onde encontra assento o ponto capitonê da função do educador, possibilitando que um vagão/sujeito engate-se a outro, servindo-lhe de locomotiva - ou de mestre, analista, histérico(a) - viabilizando no aprender o trabalho inconsciente do tempo lógico, na retroação de construção de sentidos via significantes, aberto às vicissitudes da vida e da equilibração majorante de cada um em direção ao circular dos objetos do conhecimento, atuando sobre o desejo, na busca pelo pequeno $a$ em causa, o que nos levou a grafar ato educ(a)tivo, e não ação educativa, tal qual Lacan o alocou no vazio central do nó borromeano. ${ }^{121}$

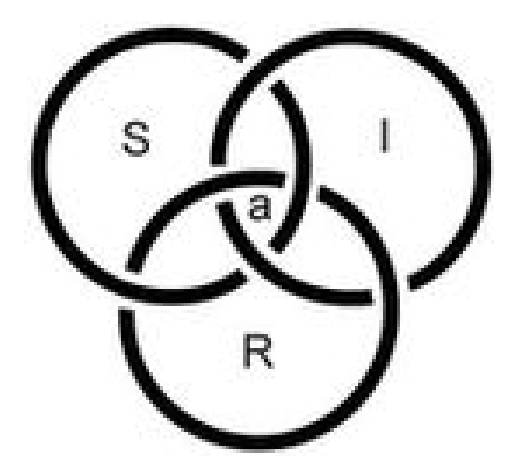

Para fazermos elo com o que virá a seguir, voltemos a Dunker, para encontrarmos que estilo está ligado à dialética do reconhecimento, reconhecimento que não é narcísico, mas que torna possível uma mediação, assim como uma educação em pedagogias não-ortodoxas, inferimos.

\subsubsection{No estofo do estilo, a dialética do reconhecimento}

Em psicanálise, a noção de demanda foi criada por Lacan como um elo para conciliar duas tradições, uma filosófica e outra psicanalítica, quando conceituou aquilo que Freud propôs enquanto idéia ou visão: o desejo. De um lado, havia a noção freudiana de Wunsch $^{122}$, traduzida por desejo, no sentido de voto ou anseio distanciado da necessidade biológica, atribuído ao inconsciente - porque ligado a reminiscências - , que se realiza na

\footnotetext{
${ }^{121}$ Ver nota 74, p. 74.

122 FREUD, Sigmund. A interpretação dos sonhos (1900). In: Edição Standard brasileira das Obras Psicológicas completas de Sigmund Freud. Rio de Janeiro: Imago, 1977.
} 
reprodução simultaneamente inconsciente e alucinatória das percepções transformadas em “signos" de satisfação, cujo caráter é sempre sexual. De outro lado, havia o que Hegel ${ }^{123}$ chamou de Begierde, entendido como desejo no sentido de

(...) apetite, tendência ou concupiscência, pelas quais se expressa a relação da consciência com o eu. Se a consciência tenta conhecer o objeto, a apreensão deste não se faz por um conhecimento, mas por um re-conhecimento. Em outras palavras, a consciência reconhece o outro na medida em que se reencontra nele. A relação com o outro passa, pois, pelo desejo (Begierde): a consciência só se reconhece num outro, isto é, num objeto imaginário, na medida em que através desse reconhecimento, instaura-se esse outro como objeto de desejo (ROUDINESCO ; PLON, 1998, p. 146).

Lacan constrói a noção de demanda para poder justamente alocar o inconsciente freudiano no lugar da consciência hegeliana descrita acima e estabelecer, assim, a ligação entre o desejo do reconhecimento e o desejo da realização inconsciente, explicando portanto que, ao demandar, o sujeito endereça ao outro demanda de amor, ou seja, desejo do desejo do outro, na medida em que busca ser reconhecido em caráter absoluto por ele (cf. Idem, ibidem, p. 146).

Quando um educador se lança a falar com o aluno, mais do que sobre ele, seja um ou mais que um, metatransmite não outra coisa que a demanda. Falar ao educando, digamos, é direcionar os pseudópodos educativos, professorais, àqueles que se entregam (ou não) ao (des)prazer de ouvir e escutar a palavra do educador, seja este encarne de mestre, histérico, obsessivo, analista, capitalista, ou universitário.

Tomemos demanda na acepção de movimento em direção a um objeto que atrai. Movimento de busca por algo investido de interesse e valor, já que o desimportante ignora-se, levando-nos a perguntar até que ponto aquele que não é feito interesse, nem valor ou importância, existe realmente e torna-se “olhável”, “escutável”, “tocável” ou reconhecível pelo aparelho psíquico do sujeito?

Pensemos: por que gastar tempo com um outro que não "eu" - esse tipo de parque interno de diversões e horrores, subdividido em instâncias psíquicas que não se entendem mas "conversam" o tempo todo entre si -, se não for justamente para enviar palavras ao destinatário pequeno outro, demandando-lhe além da atenção e ouvidos, algo a mais? Caso contrário, não haveria motivo para movimentar-se para fora e deixar em segundo plano o contínuo e instigante embate intrasubjetivo pelo qual neuróticos deliciam-se e martirizam-se. Manteríamo-nos ali, a girar sem desejo, em pleno gozo - para além do princípio do prazer. Se

\footnotetext{
${ }^{123}$ HEGEL, Georg Wilhelm Friedrich . Fenomenologia do espírito. Petrópolis: Vozes, 2003.
} 
desviamos parte do tempo a ser gasto com nosso próprio aparelho psíquico no endereçamento de palavras ao outro, no caso os alunos, educandos, é porque, neuróticos que somos, desejamos algo desse objeto e vamos buscá-lo - fato que não passa incólume ao sujeito que recebe a demanda, que também se angustia diante dela, indagando a si mesmo: $\mathrm{O}$ que quer de mim? O que em mim tanto interessa, causa?

Che vuoi?, Que queres? Forcem um pouquinho mais o funcionamento, a entrada da chave [do que a doutrina freudiana introduz sobre a subjetividade], e terão Que quer ele de mim? (Que me veut-Il?), com a ambiguidade que o francês permite no mim (me) entre o complemento indireto ou direto. Não se trata apenas de Que quer ele comigo?, mas também de uma interrogação em suspenso que concerne diretamente ao eu: Como me quer ele?, mas Que quer ele a respeito deste lugar do eu? (LACAN, 2005, p. 14, acréscimo nosso).

O problema é que o endereçamento ao outro implica a sujeição de quem fala a, pelo menos, dois tipos estrangeiros de retorno, pois os efeitos das enunciações, para o espanto de muitos, nem sempre chegam ao previsto, ainda que exista a feliz possibilidade. É bom lembrar que aqui, ao falarmos de palavras, não nos referimos apenas àquelas sonoras saídas da boca de um sujeito em direção aos ouvidos de outro(s), originadas por multicombinações fonéticas e silábicas, agrupadas em conexões sintáticas cujas significâncias unívocas traduzem representações produzidas pelos cérebros de modo a viabilizar, através do diálogo recíproco, entendimentos racionais. Não! Aqui, a palavra tem um outro estatuto, porque além de incluir o entendimento comunicativo compartilhado pelos linguistas, inclui-se o que é da ordem do conceito de significante, conforme subverteu Lacan, de maneira a incluir nas construções deslizantes da significação da fala - ou melhor, dos atos de linguagem - o nãodito, o inter-dito, o silenciável e até mesmo o que é da ordem do indizível. Se para Saussure o signo é uma unidade indissociável constituída entre significado e significante, para Lacan esses dois elementos estão separados pela barra do inconsciente, indicando duas ordens distintas. Por interpor uma resistência à significação, a barra quebra a pretensa unidade do signo, cabendo ao encadeamento da cadeia significante, no après-coup, do tempo lógico, a produção dos significados lábeis, fazendo com que nenhum significado possa ser pensado fora de sua relação a outros significantes. Por exemplo, dizer "O rapaz olhava através do buraco" é completamente diferente de dizer "O rapaz olhava". O sentido da oração só aparece com o ponto de basta, ou seja, após a última palavra haver sido proferida. O ponto de capitonê.

Voltemos então aos dois tipos estrangeiros de retorno das enunciações. 
Quando um sujeito fala a outro, seja oralmente ou na linguagem de sinais, por mímica, pela linguagem das mãos, pela pintura, música, dança, gesto, olhar ou reação fisionômica - por qualquer ato de linguagem, enfim - nada garante que o recebido será equivalente ao enviado em intenções originais, ainda que o emissor tenha se esmerado em meios e métodos. Para professores inavisados, seria bom informar, por exemplo, que as respostas a serem recebidas após uma preciosa exposição didática, ou mesmo demonstração empírica de todo "construtivista", dificilmente se enquadrarão ipsis litteris àquelas imaginadas por ele quando do envio de sua demanda em enunciação. O desvio de rotas nos entendimentos e assimilações de conteúdos escolares, por exemplo, são fenômenos que ocorrem com grande frequência, para destempero de muitos educadores. A brincadeira do telefone sem-fio faz boa ilustração disto que ocorre na transmissão de palavras entre sujeitos: cada um muda um ponto, acrescenta uma vírgula, troca uma letra, faz uma rasura, deixa um traço, de forma que a mensagem inicial se transforma e torna-se irreconhecível, para deleite do grupo quando fica sabendo, no final da roda, a ideia lançada ao ouvido do primeiro "brincador". Poderíamos aludir, também, à variância das notas de aproveitamento dos alunos de uma classe, porque apesar de serem expostos aos mesmos encaminhamentos pedagógicos, os alunos são capazes de processar as informações de forma singular, por vezes até non sense, do ponto de vista do professor e demais colegas. Problema de zona do desenvolvimento proximal ou das estruturas cognitivas, dirão os sócio-construtivistas, problemas de dislexia, disgrafia, déficit de atenção, hiperatividade, baixo quociente de inteligência, estrutura familiar, senão outros, dirão os atualizados para-educadores, médicos e pretensos conhecedores do funcionamento psíquico. Coisas da equilibração majorante, diremos nós...

- "Eus" universitários, senhores tudosaber nas casas dos outros...

Porém, ver o currículo chegar a um ponto não vislumbrado pelo educador não é a única possibilidade de desvio para o endereçamento da demanda educativa. Outra possibilidade se faz presente nos trâmites do educar e talvez possa ser interessante que o "adulto" se inteire dela pois, quando ocorre, é o educador que articula a pergunta: o que este não crescido quer de mim?, embora isso possa ser uma inversão de seu próprio pedido e não, necessariamente, de uma demanda que o aluno realmente lhe fez, visto que o trabalho docente está aberto à profusão de fantasias especulares de ambos os lados. Vai saber...

Por estarem afeitas aos deslizamentos de sentidos, não há como impedir que, vez em quando, palavras lançadas ao outro, repentinamente circulem o objeto buscado, deem meia- 
volta e retornem em direção ao aparelho psíquico daquele que fala, feito mensagem invertida $^{124}$, movimento primo ao que ocorre quando o infantil (isto que sobra dos tempos de infância e permanece vivo para o gozo das disputas intrapsíquicas) retorna do recalcado, causando mal-estar. Nesses momentos, deparamo-nos sem aviso prévio com as crianças impulsivas que não esperávamos reencontrar dentro de nós, como apontou, em 1930, o educador e psicanalista Bernfeld (cf. FILLOUX, 2002, p. 90), por julgarmos que estavam mortas e enterradas, fruto do trabalho realizado pelo amadurecimento racional do "adulto" que, agora civilizado e crescido, imagina-se livre do indomesticável. Pura ilusão - o que nas palavras de Freud em O Futuro de uma Ilusão não passa de crença alimentada por um desejo - , no caso, desejo de não ser mais habitado pelo infantil, esse estrangeiro Outro, a enviar de forma invertida as próprias mensagens recalcadas, amortecidas, subliminares.

Em suma, por melhor preparado que esteja o educador, seguindo à risca os preceitos didático-metodológicos que estudou e aprendeu em sua formação sempresempre continuada, em rol de preceitos tidos como ideais, o retorno da demanda educativa endereçada ao aluno sempre sujeito, pero nem sempre tomado como - pode escapar repentinamente pela culatra e atingir o educador em seu íntimo, bem onde jamais esperou. A peleja que a demanda educativa lhe impõe passa exatamente por aí. Então, vale o lembrete:

Dedicar-se à infância e, ao mesmo tempo, defender-se é o destino que poderia chamar de profissional e até apaixonante das pedagogias. O risco do ofício ${ }^{125}$ é, justamente, ter de ser confrontado com essas três crianças [a real, a ideal e a recalcada], com os próprios recalques e com suas próprias pulsões infantis, soterradas no seu inconsciente. A criança real o faz retornar às duas crianças que existem nele. E essa criança que tem diante de si: ou vai encontrar o ideal, maravilhoso que imagina ter sido, ou, então, será confrontado com a criança recalcada e, então, vai contra-transferir. Ou, ainda, vai esperar que a criança real, restaure nele a criança ideal. E nessa ótica, ele próprio estará numa situação de projeção identificadora e poderá viver, de modo difícil, esta situação (FILLOUX, 2002, p. 91, acréscimo nosso).

\footnotetext{
${ }^{124}$ LACAN, Jacques. (1966). "Função e campo da fala e da linguagem em psicanálise”, in Escritos. Rio de Janeiro: Jorge Zahar, 1998, p. 238-324.

125 Referência ao texto de Daniel Hameline, não traduzindo para o português, "Les risques du métier, psychanalyse de l'enseignement", in Attention! écoles, Paris, Fleures, 1972, no qual o autor, ao retomar a temática de S. Bernfeld, avança na questão sobre o voto pedagógico, a vocação do professor. Hameline defende a ideia de que esta é uma vocação difícil, suspeita, além de fatigante e deprimente, pois por deter a capacidade latente de reativação das neuroses - fator não encontrado em grau semelhante na média das profissões - torna-se uma profissão das mais ameaçadoras psicologicamente, já que pode estar ligada também às perturbações encontradas na conduta da percepção de si mesmo, de outrem ou da vivência dos relacionamentos intersubjetivos.
} 
Sendo assim, caso o educador não tenha feito as pazes com os desejos pulsionais da criança que um dia foi, dificilmente fará de sua atuação profissional algo diferente de um tormento para seus alunos e de gozo para si, pois o contato transferencial e contratransferencial com estes fará ebulir toda a gama inconsciente que, por estar numa faixa etária numericamente avançada, considera-se adulto e não se priva de exigir da criança real, postada em sua frente, que encarne a criança ideal que ele mesmo não conseguiu cumprir. Em casos assim, não há metodologia de ensino que evite e suture os descompassos que irão surgir no dia a dia desse professor, e/ou educador, ainda que seus alunos estejam esperando por sua intervenção nas ditas e supostamente localizadas zonas proximais de desenvolvimento, ávidos por estímulos que impulsionem sua inteligência a galgar um nível superior nas estruturas cognitivas. Com método ou sem método, a metatransmissão entre inconscientes acontecerá, simplesmente porque é inevitável, ensina a psicanálise. Se em algumas ocasiões esse metatransmitir será aliado do professor, pela via da transferência positiva, em outras poderá em nada ajudar, dificultando ainda mais a tarefa incerta do educar, a transcorrer sempre na via de mão dupla, moebiana, do ensinar e do aprender, a partir do quê não é possível prever as formas de cada sujeito se apropriar daquilo que lhes tenta mostrar corpo e palavra do professor, corpo e palavra do aluno, também. Antecipando o próximo capítulo, a primeira ilustração do pêndulo de educar.
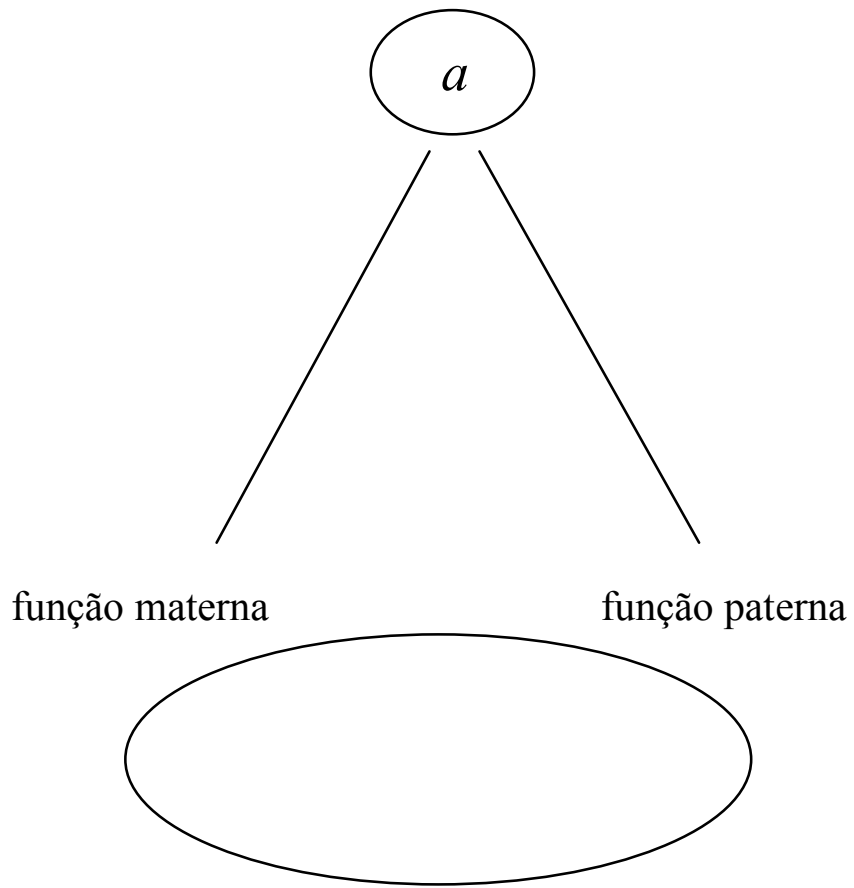


\section{Um doutor}

Um doutor veio formado de São Paulo. Almofadinha.

Suspensórios, colete, botina preta de presilhas.

E um trejeito no andar de pomba rolinha. No verbo

diga-se de logo, usava naftalina. Por caso, era

um pernóstico no falar. Pessoas simples da cidade

lhe admiravam a pose de doutor. Eu só via o casco.

Fomos de tarde no Bar O Ponto. Ele, meu pai e este

que vos fala. Este que vos fala era um rebelde

adolescente. De pronto, o Doutor falou pra meu

pai: Meus parabéns Seo João, parece que seu filho

agora endireitou! E meu pai: Ele nunca foi torto.

Pintou um clima de urubu com mandioca entre nós.

O doutor pisou no rabo, eu pensei. Ele ainda

perguntou: E o comunismo dele? Tá quarando

na beira do rio entre as capivaras, o pai respondeu.

O doutor se levantou da mesa e saiu com seu

andar de vespa magoada

Manoel de Barros

Memórias Inventadas: A Segunda Infância 


\title{
4. O pêndulo de educar
}

\author{
Às vezes tenho a impressão de que \\ escrevo por simples curiosidade intensa. \\ É que, ao escrever, eu me dou as mais \\ inesperadas surpresas. É na hora de \\ escrever que muitas vezes fico consciente \\ das coisas, das quais, sendo inconscientes, \\ eu não sabia que sabia. \\ Clarice Lispector
}

Desde o início temos procurado circular a hipótese, ou talvez simplesmente metaforizar, de que a função do educador, pelo endereçamento ${ }^{126}$ da palavra ao educando, sustenta-se no funcionamento pendular entre dois extremos.

Em meados de 2010, parte deste trabalho foi submetida à banca de qualificação composta pelos professores Maria Cecília Cortez Christiano de Souza (FEUSP) e Christian Ingo Dunker (IPUSP), de quem recebeu considerações de apreço, críticas e sugestões, pelas quais reiteramos os agradecimentos. Ao final de sua arguição, Dunker perguntou por onde tínhamos a intenção de seguir. Respondi que tencionava continuar na trilha do que vinha elaborando como um modelo - pendular - para representar a função do educador como uma espécie de reeditor do que um dia fôra apresentado ao infans, à criança e ao adolescente, na trama edípica familiar, enquanto desejo-da-mãe e nome(s)-do-Pai. A contra-resposta foi de grande serventia: o pêndulo descrito poderia ser tomado ou aceito como um modelo (científico)? E se fosse - tivemos que ampliar - , até ponto seria aplicável aos questionamentos que nos locomovem a respeito da função do educador? Foi preciso averiguar.

\section{1 - Um protomodelo}

Luís Fernando Sayão (CNEN/CIN - Centro de Informações Nucleares da Comissão Nacional de Energia Nuclear), responde pela autoria de um texto essencial a esta discussão.

\footnotetext{
${ }^{126}$ No trabalho anterior, mais precisamente no quarto capítulo de Educar: uma questão metodológica (2006), desenvolvemos o tema do modo de endereçamento, conceito tirado dos teóricos de cinema, segundo Elisabeth Ellsworth, desenvolvido por eles para lidar de uma forma específica com questões que, além de atravessar os estudos cinematográficos, também estão presentes na crítica de arte e literatura, sociologia, antropologia, história e educação, questões que têm a ver, digamos, com a relação entre o "social" e o subjetivo.
} 
Trata-se de Modelos teóricos em ciência da informação - abstração e método científico, em cuja primeira parte encontra-se o que, atualmente, é aceito pela comunidade científica como definição de "modelo". Começa assim:

$\mathrm{Na}$ busca de novos esclarecimentos e conhecimentos de novos fenômenos e eventos, o ser humano não os identifica somente pelas sensações ou pelas manifestações imediatas, mas recorre à reflexão e ao conhecimento acumulado, através da formulação de hipóteses e da estruturação de modelos. Dessa forma, a abstração constitui uma ferramenta poderosa no exercício eterno de aquisição de conhecimento, uma vez que, para se compreender a imensa variedade de formas, estruturas, comportamentos e fenômenos residentes no nosso universo, é necessário selecionar aqueles de maior relevância para o problema objeto de investigação e elaborar para eles descrições adequadas. Constroem-se, assim, esquemas abstratos da realidade, nos quais as coisas são reduzidas a seus perfis mais convenientes (SAYÃO, 2001, p.82).

Ainda que os processos educativos não sejam fenômenos propriamente "novos" e o trabalho do educador/professor exista, pelo menos, desde o mundo antigo, tentar descrevêlos e analisá-los sob outro paradigma que não o hegemônico psicometodológico encontra sua valia, queremos acreditar, não apenas na viabilização de estudos pertinentes ao campo educativo em outros escopos de conhecimento, mas também por permitir, senão mesmo exigir daqueles que se voltam a estes estudos uma ruptura em termos do que se prega como ideal para essa prática social, inclusive quando pedagógica. Contudo, não estamos apresentando nada que sirva de modelo a ser seguido, menos ainda de padrão a ser imitado, no que se efetiva enquanto educação ideal. Ao defender a possibilidade de um ideal de educação pelos estudos realizados de psicanálise $\boldsymbol{n a}^{127}$ educação, afirmamos de maneira nem visionária, nem demiurga que, com o tempo e alguma sorte, talvez consigamos ajudar a concretizar uma ruptura nas condutas educativas e pedagógicas, embora já tenhamos apreendido, pelas descobertas psicanalíticas, que o homem é dado a crenças e ilusões, alerta que não nos permite ser ingênuos, muito menos otimistas, até mesmo porque pôr-se em campo em Nome(im)próprio será sempre menos cômodo e mais trabalhoso do que entregar-se às formas prontas que prometem o caminho mais curto e assertivo a ser seguido. Seja como for, revolver o que está assentado há décadas, senão há séculos (e a matriz didático-metodológica, por exemplo, é um sedimento secular), mobilizará resistências e poderá parecer, a muitos, temeroso porque, simplesmente, parece puxar o tapete das certezas continuamente

\footnotetext{
${ }^{127}$ Mais uma vez é preciso referendar o autor: "A psicanálise "aplicada" à educação consiste - em meu entender - em analisar, dissolver, as ilusões tecnocientificistas que imperam no campo educativo com vistas à educação para a realidade impossível do desejo. Talvez caiba falarmos, então, de psicanálise na educação" (LAJONQUIÈRE, 2010, p. 71, grifo nosso).
} 
reconstruídas e atualizadas sobre a educação ideal pregada na e pela matriz psicopedagógica. Todavia, não podemos não tentar .

Diferente de outrora, segundo Sayão, os cientistas de hoje já se apercebem de que suas teorias são criações da mente humana, propriedades de um mapa conceitual da realidade, mas não pertencentes ao domínio da mesma, sendo todo o esquema conceitual necessariamente limitado e aproximado como, de resto, o são as teorias científicas. Por conseguinte, o que torna a ciência tão bem-sucedida, de acordo com Fritjof Capra ${ }^{128}$ :

(...) é a descoberta de que podemos utilizar aproximações. Se nos satisfizermos com uma 'compreensão' aproximada da natureza, podemos descrever grupos selecionados de fenômenos, negligenciando outros que se mostrem menos relevantes. Assim, podemos explicar muitos fenômenos em termos de poucos e, consequentemente, compreender diferentes aspectos da natureza de forma aproximada, sem precisar entender tudo ao mesmo tempo. Esse é o método científico: todas as teorias e modelos científicos são aproximações da verdadeira natureza das coisas; o erro envolvido na aproximação é, não raro, suficientemente pequeno para tornar siginificativa essa aproximação (Idem, ibidem, p. 82-83).

Nesse sentido, acrescenta o autor, todo modelo é uma criação cultural, um "mentefato" 129 , destinado a representar a realidade ou alguns aspectos dela, a fim de tornálos observáveis e/ou descritíveis qualitativa e quantitativamente. A existência de modelos fundamenta-se, pois, "na impossibilidade cultural de descrever os objetos com perfeição, esgotando as possibilidades de observação". Não sendo transparente para o homem, o mundo se lhe apresenta como um permanente desafio à descrição de forma que, por conta dessa limitação filosófica de percepção, o fazer científico não só permite, como acaba exigindo, elaboração de modelos (cf. Idem, ibidem , p. 83).

Em nossa pesquisa, a princípio, quando escolhemos a imagem pendular para demonstrar analogamente o que reverbera da prática com a clínica do aprender amplificado pela experiência educativa e pedagógica de Sullivan e Keller, na qual a oscilação entre o desejo e um Nome era sustentada em sua radicalidade - , atentando para o que experienciamos como um movimento oscilatório e (ir)regular da função do educador ao qual não é possível se furtar - embora muitos o façam, sem se dar conta - , não havíamos pensado no experimento de Foucault, mesmo porque o desconhecíamos, mas sim no pêndulo

${ }^{128}$ O tao da física, Cultrix, 1983, p.160.

129 Segundo o matemático Ubiratan D'Ambrósio, o termo "mentifact" no sentido de "mental constructs having no direct correspondence to real objects, people, or events" foi usado primeiramente por Charles J. Lumsden e Edward O.Wilson Genes, em Mind and Culture, Harvard University Press, Cambrigde, 1981, p. 376. Disponível em: http://www.rpi.edu/ eglash/isgem.dir/texts.dir/ubi.htm. Acesso em 24/01/2011. 
simples, instrumento bastante utilizado nos estudos da Mecânica, especificamente nos que se voltam aos movimentos oscilatórios e que serviu, no século XVII, para que fosse inventado o relógio de pêndulo capaz de minimizar a segundos a margem diária de erro na contagem do tempo - cronológico.

Um pêndulo simples consiste de um fio de massa desprezível e inextensível, cuja extremidade inferior possui um corpo com certa massa, enquanto a superior é fixa em um ponto de suspensão. Quando esse corpo, não mais em repouso, é posto a pendular, oscila sob a ação da força de seu peso e da tensão com o fio, apresentando movimento periódico, além de um plano de oscilação determinado pelas condições iniciais de sua soltura. Quem descobriu a periodicidade do movimento pendular, no século XVI, foi Galileu Galilei, cujos estudos levaram-no, basicamente, a duas grandezas: o período $(T)$ - intervalo de tempo em que o objeto percorre a trajetória entre sair e retornar à posição original - e, derivada deste, a frequência $(f)$ - numericamente igual ao inverso do período $(\mathrm{f}=1 / \mathrm{T})$, caracterizada pelo número de vezes, ou ciclos, que o objeto percorre a trajetória pendular num intervalo de tempo específico. Entretanto, quando tentávamos entender e encaixar o pêndulo simples à hipótese que temos fomulada, fomos pegos de surpresa pela existência de um outro mais específico, o de Foucault, que fertilizou a perlaboração ${ }^{130}$ de nossas questões, sem anular, entretanto, a importância da figura inicial. Apostando que algo parecido possa ocorrer a outros pesquisadores que compartilhem nossa linha de pesquisa, talvez não fosse equivocado considerar a representação proposta aqui apenas como aquilo que, de fato, nos parece ser: um protomodelo, uma representação inicial, no sentido de analogia elaborada para ampliar a discussão que nos instiga.

Dentre os vários aspectos, os modelos apresentam uma analogia, sempre que possível, mas nem sempre desejável, com o objeto real. Por analogia entendese a representação de uma mesma função em diversos materiais e por meio de princípios diversos. Ela pode ser construída por meio de formalismos matemático, fenomenológico ou conceitual. É mais simplificada, permite testar hipóteses, tirar conclusões, caminhar no sentido da generalização e da particularização, através de processos de indução, e tem sempre uma vida provisória. Cada modelo expressa e justifica um método de abordagem de uma realidade física, ao mesmo tempo em que cada método subentende um modelo, nem que seja um modelo meramente operacional. Os modelos

130 Perlaboração é um termo que não se encontra nos dicionários em português: "Esse neologismo [perlaboration] foi introduzido por Jean Laplanche e Jean-Bertrannd Pontalis, em 1967, para traduzir para a língua francesa o verbo alemão durcharbeiten (elaborar, trabalhar com cuidado), empregado por Sigmund Freud para designar um trabalho inconsciente que é próprio do tratamento psicanalítico. Esse verbo e o processo que ele designa não têm, em Freud, o estatuto de conceito que lhes é justificadamente atribuído pelos autores franceses. A perlaboração (elaboração inconsciente) permite ao analisando integrar uma interpretação e superar as resistências que ela desperta. Na língua inglesa, durcharbeiten foi traduzido por working-trhough (literalmente, trabalhar através)" (ROUDINESCO ; PLON, 1998, p. 174). 
apresentam também uma dimensão heurística, na medida em que, criados para explicar e fazer compreender alguns aspectos de uma realidade, são factíveis de evolução e de assegurar a percepção de outros aspectos não imaginados antes de sua elaboração. Por outro lado, uma mesma realidade física pode possuir mais de um e diferentes modelos (...) podendo, além de suas limitações, chegar a explicações complementares ou contraditórias com outros modelos (SAYÃO, 2001 , p. 83, grifo nosso).

Se de fato, no desenrolar de nossos estudos, fizemo-nos deixar em segundo plano o pêndulo simples para utilizar o aparato do pêndulo de Foucault, outro motivo não tivemos senão, para fins de comparação, poder acrescentar dois componentes à figura inicial, como explicaremos dentro em pouco. Antes, contudo, convidamos ao entendimento da lógica daquele que figura dentre os dez mais belos experimentos da Física.

Em referência ao físico do Observatório de Paris, Jean Bernard Léon Foucault, o pêndulo de Foucault foi concebido por ele para demonstrar a rotação da Terra em relação a um referencial, acabando por demonstrar, também, a atuação de uma força fictícia, denominada força de Coriolis, responsável, por exemplo, pela forma como escoam os líquidos pelos ralos e tubulações - anti-horário no hemisfério norte, horário no hemisfério sul - , pela intensidade e rotação das massas tempestuosas, assim como pelo desvio angular descrito pelo pêndulo de Foucault a cada oscilação, o que só pôde acontecer devido a existência, nesse pêndulo, de dois referenciais, sendo um inercial e outro não.

A força de Coriolis $^{131}$, que atua de maneira transversal ao plano de oscilação do pêndulo, alterando-o, surge devido à rotação terrestre, causando uma diferença angular no plano de oscilação de acordo com a latitude em que o dispositivo se encontre instalado ${ }^{132}$.

131 Gaspard Gustave Coriolis, cientista francês, com base em estudos da mecânica de operação de máquinas, analisou movimentos relativos de engrenagens em diferentes sistemas de referências. Em 1835 publicou um estudo - Sur les équations du mouvement relatif des systèmes de corps - descrevendo, sob o ponto de vista de um observador presente em um referencial em rotação, as leis de Newton para um corpo em um sistema de referências fixo. Neste trabalho, propunha que a força total que agiria sobre o corpo no referencial fixo, quando medida pelo observador em rotação, seria constituída por forças reais devidas à gravitação, atrito, dentre outras, além das forças fictícias que não estariam presentes se o observador se encontrasse no mesmo referencial que o corpo em rotação. Na física, as forças fictícias são três: centrífuga, azimutal e esta que levou o nome de Coriolis. Atribui-se a origem dessas forças fictícias, portanto, e em especial a da força de Coriolis, à existência de pelo menos dois sistemas de referências, um dos quais deve estar, necessariamente, em rotação (cf. BORGES e BRAGA, 2010).

${ }^{132} \mathrm{O}$ pêndulo de Foucault mostra, por exemplo, que quanto mais próximo estiver da linha do Equador, ou seja, da latitude zero, menor será o ângulo de desvio provocado pela força de Coriolis, desenhando na base uma "roseta" de muito mais pontas do que um pêndulo que esteja localizado em latitude próxima aos polos Norte ou Sul. Na verdade, na latitude zero, o pêndulo nem sequer desenha mais a "roseta", porque a agulha traça na areia apenas linhas coincidentes, o que resulta um único traçado. Por esse motivo, por exemplo, os furacões tendem a se desfazer à medida que se aproximam da linha do Equador por perderem a velocidade de rotação. Disponível em: http://www.passeiweb.com/saiba_mais/voce_sabia/ciclones_furacoes. Acesso em 28/01/2011. 
Segundo Borges e Braga (2010) a deflexão ${ }^{133}$ horizontal de objetos em queda livre participou de um dos principais debates científicos no século XVII, sendo a análise correta desse problema motivada pela discussão milenar acerca da rotação da Terra em torno do próprio eixo. Um dos pioneiros, também nessa investigação, foi Galileu Galilei, idealizando um experimento em que um objeto era lançado do alto de uma torre de maneira a sofrer queda livre. Segundo Galileu, se a Terra realmente estivesse em rotação, tudo em sua superfície também estaria, incluindo a torre, que possuiria velocidade angular ligeiramente diferente em suas partes inferior e superior. Quantificando essas ideias, Galileu previu que o objeto em queda desviar-se-ia sutilmente para o leste mesmo que nenhuma força aparente, que não a gravidade, atuasse sobre o mesmo. Entretanto, a comprovação dessa outra força (mais tarde nomeada de força de Coriolis) só seria demonstrada no século XIX com o experimento idealizado e construído por esse outro cientista, Foucault, sendo a variação do ângulo do plano de oscilação provocada por ela.

- Coisas do mundo e do tempo lógico e cronológico da ciência: em torno do pêndulo de Foucault, elucubrações de três pensadores, em três séculos, encontraram-se em explicações e demonstrações.

Isto que talvez possa parecer mera digressão em nossa linha de pensamento, não obstante, alude a um aspecto importante de nossa modelagem, nada menos que a possibilidade de considerar em lugar de um, dois referenciais desacoplados, o do educador/professor e o do educando/aluno, como dinâmicas logicamente distintas, descontínuas e irredutíveis entre si, tal qual acontece entre a rotação da Terra e a força de Coriolis, embora esta última só exista em função da primeira, enquanto, de outra feita, tudo o que faz parte do planeta, desde as moléculas até as massas de ar, inexistem sem que estejam sujeitas aos efeitos da segunda. E de fato, embora dividam os mesmos espaço e tempo cronológico do educar, o tempo lógico do inconsciente do educando e do educador não parecem compartilhar da mesma dimensão. Por exemplo, se quiséssemos descrever a função do educador e a função do aluno num mesmo plano, como acontece com as retas nos planos cartesianos, dificilmente conseguiríamos, por motivos de ordem significante, pois suas retas, por conta da diferença real e desproporcional que existe entre uma criança e um adulto, ou um aluno e um professor - e este é um tema importante no último livro de Lajonquière (2010), Figuras do Infantil - essa desproporção real só poderia gerar vetores não-coplanares, motivo pelo qual não foi possível ficarmos com a figura do pêndulo simples. Este, aliás,

\footnotetext{
${ }^{133}$ Ou diferença na trajetória de um projétil; alteração ou desvio da posição natural para um dos lados, segundo o Dicionário Houaiss.
} 
talvez possa ser usado para ilustrar a matriz hegemônica psicopedagógica, em que ambos, educando e educador, mantém-se atados pelo único referencial imaginário - o da suposta realidade concreta dos fatos e das condutas tidas como adequadas ao desenvolvimento da necessidades orgânicas, psicológicas e cognitivas do indivíduo monádico - uma vez que o educador, supostamente já "desenvolvido" o bastante e ainda dotado de conhecimentos psicopedagógicos essenciais, encontra-se bem "capacitado" para estimular e interagir com o desenvolvimento natural daqueles que ainda não chegaram lá, podendo ambos girar juntos, tanto em espaço, quanto em cronologia sincronizada, motivo pelo qual o único plano de oscilação do pêndulo mostra-se suficiente, na contingência educativa que houver, motivo pelo qual seja mais palatável tanto aceitar, quanto prescrever sugestões de encaminhamentos metodológicos e didáticos descritos em forma de diretrizes para as necessidades educativas “comuns" ou especiais.

De acordo com Borges e Braga (2010), o primeiro desses pêndulos foi montado por Foucault, em 1851, na casa em que morava, onde conseguiu construí-lo de forma que oscilasse com liberdade para girar em qualquer direção. Feito isso, notou com o passar do tempo o plano de oscilações sofrendo pequenas mudanças, o que interpretou como sendo um fenômeno causado pela existência de dois referenciais: um referencial fixo - o do pêndulo - , e outro em rotação - o da Terra. A maior dificuldade para a realização da experiência consistia, entretanto, na impossibilidade de suspender o pêndulo em um ponto fora do planeta, no espaço, de forma que os referenciais não estivessem mais ligados. Então resolveu esse impasse suspendendo o pêndulo a grande altura, empregando um fio muito fino e resistente dizem que uma corda de piano - amarrado a uma esfera pesadíssima para que, assim, fossem anulados os efeitos de torção do fio, o que permitiu que o plano vertical do pêndulo se movesse de maneira separada, experimentalmente, da rotação da Terra. Depois de testar seu experimento no próprio Observatório onde trabalhava, com dimensões já superiores às testadas em casa, Foucault fez de sua demonstração um verdadeiro espetáculo público, em escala bastante ampliada, realizando-a ironicamente sob a abóbada da cúpula do Pantheon de Paris que, originalmente, fôra construído para abrigar a Igreja de Saint Geneviève. 


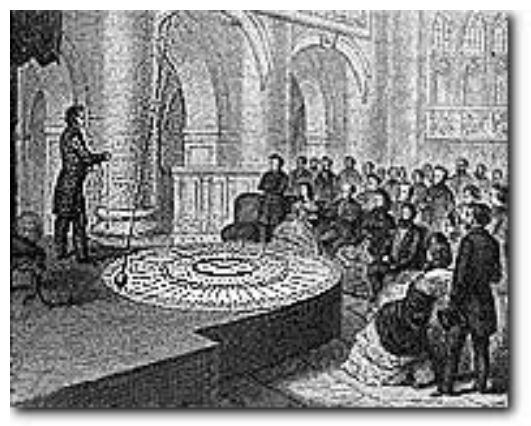

Figura 4.1-1 ${ }^{134}$ Apresentação pública do pêndulo de Foucault no Pantheon de Paris, 1851.

Do teto, fez pender um fio de aproximadamente $68 \mathrm{~m}$, sustentando no seu extremo móvel uma esfera de cobre com quase 28 quilos, com uma ponta de metal na parte de baixo, permitindo tornar visível o desvio do plano e, por consequência, provar o movimento do planeta em redor do seu eixo, dispondo sob o pêndulo uma base circular com areia, de forma que, lenta e ritmadamente, a figura de uma estrela ou roseta ia sendo desenhada, conforme o movimento pendular.

Atualmente, em laboratórios de física, é possível construir esse mesmo pêndulo em menores proporções, bastando que a extremidade superior do fio seja fixada em algum tipo de girador $^{135} \mathrm{e}$, na extremidade inferior, haja um peso com massa suficiente para permitir ao pêndulo que oscile, desta forma sujeita à direção da força de Coriolis, como mostram as Figuras 4.1-2 e 4.1-3.

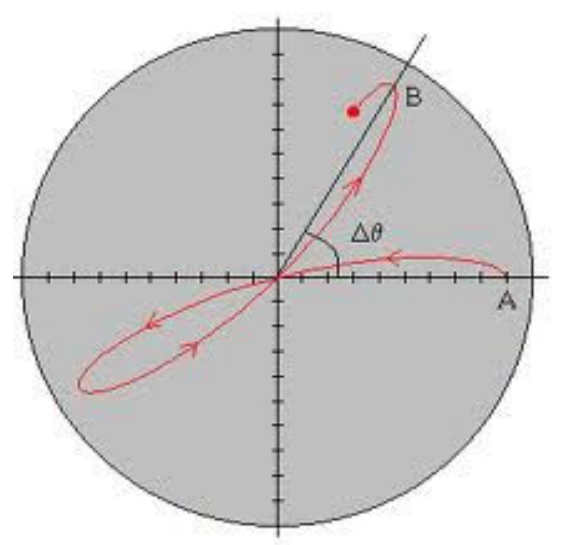

Figura 4.1-2 Desvio do plano de oscilação ${ }^{136}$

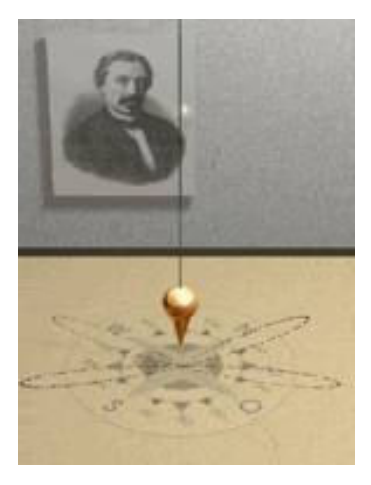

Figura 4.1-3 Pêndulo de Foucault

\footnotetext{
${ }^{134}$ Disponível em: http://www.almanaque.cnt.br/foucault.jpg . Acesso em 31/01/2011.

${ }^{135}$ No Anexo B há uma imagem de um girador fabricado nos dias de hoje.

${ }^{136}$ Disponível em http://www.fisica.ufs.br/CorpoDocente/egsantana/cinematica/coriolis1/coriolis1.htm. Acesso em $25 / 01 / 2011$.
} 
Assim, Foucault conseguiu demonstrar, sem cálculos, que a superfície abaixo do pêndulo girava, ou seja, a Terra, mas só enquanto o fio ligado ao pêndulo fosse mantido, pelas condições ideais do aparelho, livre para oscilar nas variâncias angulares, sem que girasse junto com o resto do ambiente, embora, de qualquer maneira, permanecesse sujeito à fixação, sim, em algum lugar do planeta em giro, seu ponto de suspensão, que não em algum lugar improvável do espaço sideral. Ou seja, a liberdade de oscilação do pêndulo, era nãotoda, senão relativa.

Nossa invencionice, bem provável, cause estranhamento. Contudo, fazemos lembrar que um modelo é, antes de mais nada, "uma representação de um recorte da realidade, que, de acordo com a sua função utilitária e por meio do seu modo de expressão, sua estrutura e suas igualdades e desigualdades em relação ao seu original tenta comunicar algo sobre o real" (SAYÃO, 2001, p. 86), sendo esse o nosso objetivo, que alguns talvez venham validar, enquanto outros, não.

- Toda unanimidade, já dizia Nelson Rodrigues... então não nos interessa.

No entanto, que o trabalho de educador não siga ipsis literis o funcionamento regular de um pêndulo, sabíamos desde o início, contudo negar a existência de uma certa regularidade, também não podemos, porque é o que experienciamos há um bom tempo no trabalho cotidiano com os alunos que se apresentam em dificuldades do aprender,. Então vamos ajeitando aqui, ali, permitindo dizer que uma coisa é o pêndulo de Foucault para o mundo da física e outra é para o nosso protomodelo, que funciona de maneira parecida, mas não igual, nem em materialidade, nem em objetivos. Mesmo porque, quando os modelos

(...) buscam a formalização do universo através de meios de expressões controláveis pelo homem; derivam da necessidade humana de entender a realidade aparentemente complexa do universo envolvente. São, portanto, representações simplificadas e inteligíveis do mundo, que permitem vislumbrar características essenciais de um domínio ou campo de estudo. (...) Esta simplificação exige criatividade, tanto sensorial, quanto intelectual, o que, evidentemente, implica admitir-se que, na construção de modelos, algumas características da realidade, que não se referem diretamente aos objetivos buscados, são desprezadas ou abandonadas, em função da maior inteligibilidade ou facilidade de compreensão (Idem, ibidem , p. 83).

Sem dúvida, foi este um recurso de que lançamos mão, o que pelo visto não constitui um erro. Enquanto representação de algum aspecto da realidade, ressalta ainda o autor, um modelo assume a natureza ambígua de ser igual e desigual à realidade que modela, pois possui a sua própria forma e estrutura, independentemente do original que representa, embora 
as afinidades e divergências entre o modelo e a realidade devam ser "expressáveis" e expressadas (cf. Idem, ibidem, p. 83), o que também estamos tentando.

Como observam Haggett \& Chorley ${ }^{137}$, um modelo é uma estruturação simplificada da realidade que apresenta supostamente características ou relações sob forma generalizada. Os modelos são aproximações altamente subjetivas, no sentido de não incluírem todas as observações e mensurações e medições associadas, mas, como tais, são valiosas por ocultarem detalhes secundários e permitirem o aparecimento dos aspectos fundamentais da realidade. Esta seletividade significa que os modelos têm graus variáveis de probabilidade de aplicação e um alcance limitado de condições sobre as quais se aplicam. Os de maior sucesso possuem alta probabilidade de aplicação e extensa gama de condições sob as quais aparecem apropriados. Com efeito, o valor de um modelo é muitas vezes diretamente relacionado ao seu nível de abstração (Idem, ibidem, p. 83).

E para polemizar um pouco mais, o autor afirma que modelos podem ser hipóteses não testadas ou insuficientemente testadas, como também teorias, sínteses de dados, funções, relações, equações, ideias estruturadas capazes de conectar argumentos que apresentem algum poder explanatório. São estruturações que representam a realidade, apresentando supostas características ou relações de forma generalizada (cf. Idem, ibidem , p. 84), o que para nós, sujeitos tec-no-lógicos, não deixa de ser interessante. Novamente de acordo com Haggett \& Chorley, supracitados:

(...) a característica mais importante dos modelos é que sua construção implica uma atitude altamente seletiva em relação às informações, na qual não só as interferências como os sinais menos importantes são eliminados para permitir que se observe algo da intimidade das coisas. Desta forma, os modelos podem ser considerados como aproximações seletivas que, pela eliminação de detalhes acidentais, permitem o aparecimento de alguns dos aspectos fundamentais relevantes ou interessantes do mundo real sob alguma forma generalizada. A possibilidade de ser inexato e desigual em relação ao seu original é que, em última análise, permite ao modelo revelar o que se deseja (Idem, ibidem, p. 84).

Uma última característica, que não podemos deixar de apontar, é a dos modelos serem estruturados de forma que os aspectos importantes selecionados da realidade para compô-los são explorados em termos de suas relações com outros modelos e aspectos da realidade, seguindo as características gerais das estruturas, conforme enunciado por Piaget ${ }^{138}$, ou seja,

${ }^{137}$ CHORLEY, Richard ; HAGGETT, Peter. Modelos, paradigmas e a nova geografia. In: CHORLEY, Richard/; HAGGETT, Peter. Modelos socioeconômicos em geografia. Rio de Janeiro: Livros Técnicos e Científicos / USP, 1975, p. 1-22.

${ }^{138}$ PIAGET, J. The concept of structure. In SCIENTIFIC thought: concepts, methods and procedures. Paris: Unesco, 1972, p. 35-56. 
estabelecendo que as estruturas constituem-se uma totalidade, com leis próprias independentes das características particulares dos seus elementos, mas que consistem de um sistema de operações de transformação cujo conjunto de combinações internas nunca geram produtos fora da estrutura.

(...) Essa característica dos modelos implica imediatamente a sua natureza sugestiva, no sentido de que um bom modelo traz, em si, na sua própria estrutura, sugestões para a sua própria extensão e generalização. Isto significa, primeiramente, que toda a estrutura do modelo tem maiores implicações do que um estudo de suas partes individuais e, segundo, que pelo modelo, por meio de operações e transformações proporcionadas por suas leis estruturais, podem ser feitas previsões do mundo real. Dessa forma, os modelos são instrumentos especulativos cujas implicações mais positivas conduzem a hipóteses e especulações novas no campo primário da investigação. (...) é interessante notar que, segundo Kaplan ${ }^{139}$, o que é denominado "modelo" pelos lógicos é chamado de "estrutura" pelos economistas (Idem, ibidem, p. 84).

Desta feita, a originalidade daquele experimento que partia de um pêndulo simples para atingir outros propósitos residia, justamente, na invenção do que para alguns passou des(a)percebido: a criação de artifícios para anular os efeitos de torção do fio, operando como uma desconexão do resto do planeta, o que tentamos transpor à nossa modelagem para atar metafórica e teoricamente, no estilo e no pequeno $a$, o fio que possibilita ao educador atingir esse objetivo de liberdade relativa de oscilação angular na empreitada educativa, artifício que chamou nossa atenção porque, inexistente no pêndulo simples, viabilizou inserir no protomodelo dois novos elementos, quais sejam, um lugar em permanente rotação para representar o educando na situação de tentarem educá-lo, ou seja, de estar exposto e expondo-se (ou não) a uma tentativa de educação; e um girador, para alocar justamente ali, no que pendura o fio da função do educador, com todo peso e tensão que lhes são característicos, o objeto causa de desejo, uma vez que a ideia desse dispositivo possibilita tanto ao fio do pêndulo, quanto às vicissitudes de um educador em a(tua)ção, manter-se preso e, ao mesmo tempo, relativamente livre para girar em torno do próprio eixo, na sujeição de forças fictícias, seja a de Coriolis, a do desejo ou a do laço com a parte da cultura que se esforçou por adquirir e que, agora, apresenta em semblante ao educando, como uma espécie de embaixador do mundo adulto e civilizado, laço este que, de maneira singular e inexorável, atravessa sua palavra, dando a medida de corte de seu estilo de endereçamento, tanto dos

\footnotetext{
${ }^{139}$ In KAPLAN, A. The conduct of inquiry. San Francisco: Chandler, 1964, p. 428.
} 
enunciados, quanto das enunciações. Lembremos que o estilo deriva do mesmo radical de estilete.

Aqui é preciso seguir com calma, porque não se mostra simples explanar o que estamos intentando captar e "contrangular".

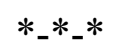

Em função de conhecimentos que o educando não detém, mas teoricamente o educador sim, uma hierarquia estrutural na educação está posta para não ser denegada ${ }^{140}$, em favor do próprio lastro da palavra educativa. Lastro, nas acepções do Dicionário Houaiss, varia um pouco, mas remete muito à função que a esfera de metal tem no pêndulo de Foucault, e que podemos também incluir em nosso protomodelo. Por lastro costuma-se entender "qualquer matéria pesada que se coloca no fundo de uma embarcação para dar-lhe equilíbrio"; pode também ser "uma camada na base de algo"; ou "um depósito em ouro que sirva de garantia ao papel-moeda". Se anuimos que a palavra educativa dependa de um lastro para pendular, assim como o pêndulo depende de um peso suficientemente grande em sua extremidade inferior para manter a oscilação constante, talvez aí possamos alocar a bagagem de conhecimento e cultura do educador, sua formação acadêmica, assim como a própria educação, seu refinamento.

Enfim, se aceitarmos que o pêndulo possa representar o educador e o disco sob ele o educando, caso o trabalho educ( $a$ )tivo seja observado da perspectiva de quem está postado na base circular no referencial aparentemente imóvel, o educando, a ser marcado pelo significantes do educador, quem aparece em movimento oscilatório entre um extremo e o outro, de maneira mais ou menos constante e em giro, completando e recomeçando sempre os 360 graus da circunferência, é o educador. Visto da outra referência, porém, do lugar por onde se pendura e gira o fio (onde um inseto poderia facilmente pousar), a perspectiva do educador seria de quem afirma que, quem está em giro, mantendo um movimento constante, é o aluno, enquanto ele, educador, não faz muito diferente do que oferecer-se a partir do mesmo lugar que seus antecessores, para riscar aquilo mesmo que educadores e professores,

\footnotetext{
${ }^{140}$ Denegação (Verneinung): "Termo proposto por Sigmund Freud para caracterizar um mecanismo de defesa através do qual o sujeito exprime negativamente um desejo ou uma ideia cuja presença ou existência ele recalca" (ROUDINESCO ; PLON, 1998, p.145); "A Verneinung na fala do paciente é indício da presença de material recalcado e da resistência contra este. É uma forma particular de lidar com a pressão da ideia recalcada para chegar à consciência, pois permite que a psique entre em contato com um conteúdo necessário ao funcionamento do sujeito, mas que, sendo inaceitável, é mantido a certa distância pela rejeição verbal e intelectual. (...) Neste sentido, Freud diz que a Verneinung é um substituto intelectual do recalque” (HANS, 1996, p. 322).
} 
desde os tempos antigos, sabem que deve ser feito, apesar das variações culturais e temporais - como por exemplo, tentar ensi(g)nar os números, a escrita, a álgebra, noções geográficas, algumas noções sobre a história do país em que se habita, a forma civilizada de se portar em sociedade, o uso das expressões polidas "com licença", "por favor", "muito obrigado", assim como aprender a esperar pela vez de falar, aprender a controlar a raiva quando se sentir injustiçado, enfim, coisas que os educadores, assim como os professores, sempre ensinaram dentro e fora das instituições escolares - mantendo-se em movimento aparentemente único, embora em realidade também em giro, sob a ação de "forças fictícias", especialmente aquelas que enlaçam o seu desejo enquanto sujeito pensador e articulador de cultura, capaz de ter prazer no estudar, no aprender, como todo professor e educador deveriam ter.

\section{- Será essa uma utopia?}

Porque dessa perspectiva talvez consiga, com mais facilidade, encontrar meios para oscilar suficientemente bem entre Cila e Caribde, entrando e saindo dos furacões que sempre se formam nas situações educativas, para os quais deverá aprender a arte de dizer sim e dizendo não, de chamar "Vem!", de mandar "Vai!", em movimento oscilante, sim, embora não periódico, nem bem regulado, motivo pelo qual o protomodelo desencaixa da exatidão com o real pêndulo de Foucault, produzindo seu quê de resto, já que a dinâmica do ensinar e do aprender não é dada na cadência dos relógios, nem dos giros planetários, mas dos acontecimentos, das pulsões e do tempo lógico do inconsciente. Caso contrário, teríamos que abrir mão do que parece irrefutável, que é o fenômeno - sempre meio fora de tempo e lugar - do amódio ${ }^{141}$ da transferência, em que o aparelho psíquico do sujeito educando se põe a atuar (ob)cenas do drama edipiano, elencando outros sujeitos-atores em cenário nada familiar, cujos protagonistas foram, originalmente, as figuras parentais, numa espécie de reedição do trígono edipiano, comentada na introdução deste trabalho. Nosso protomodelo permite assim, para além dos desenvolvimentos cronológicos, elucubrações a respeito do tempo lógico inconsciente dos efeitos de uma educação, embora tal desdobramento não seja o objetivo desta dissertação.

\footnotetext{
${ }^{141}$ Amódio: “Até seus textos mais derradeiros, como 'Análise terminável e interminável' , Freud no próprio modo como retoma os termos de Empédocles, Philia e Neikos, como equivalentes de amor e ódio, não distingue a philia de Eros, nem o ódio da agressividade. Em 1973, em seu seminário Mais, ainda, Lacan empreende o que podemos chamar de um elogio ao ódio, e produz o neologismo "amódio" (hainamoration). O ódio não é querer o mal do outro, destruí-lo; isso seria a agressividade. O ódio, a maldade, é o que cai mal quando se quer o bem do outro e as coisas dão infalivelmente errado, o outro não querendo saber de meu ser sabendo seu bem. No acesso ao ser reside a ponta extrema do amor, mas a relação de ser a ser não é uma relação de harmonia. "O verdadeiro amor desemboca no ódio", e nisso ele faz transpor o limite da amizade, do querer o bem do outro, presos à imagem do semelhante ( M. Viltard, in KAUFMANN, 1996, p. 33).
} 
De qualquer forma, cabe ao educador tentar lidar - de saída, como sugeriu Melman com o impossível constitutivo do educar, porque de maneira ou outra fez uma escolha por ocupar um lugar de mestria. E caso tenha ainda, mesmo "sem-querer-querendo", escolhido a profissão de professor, encontrando meios, na vida adulta, de voltar e manter um lugar para si dentro da escola, seja ela de nível básico ou superior, deve procurar suas implicações subjetivas para tê-lo feito porque, muito provavelmente, foi por conta de seu aparelho psíquico não ter ainda acertado os ponteiros "lógicos" com a criança que um dia foi para si e os próprios pais, conforme acenaram Siegfried Bernfeld ${ }^{142}$ e Daniel Hameline ${ }^{143}$ em textos que, infelizmente, ainda não foram traduzidos para o português, assim como o imprescindível livro de Mireille Cifali e Jeanne Moll, prefaciado por Jean Claude Filloux, publicado em 1985, em Paris, com parte dos 300 artigos de psicanalistas, pedagogos e educadores que, entre 1926 e 1937, escreveram para a revista alemã Zeitschrift für Psichoanalytische Pädagogia.

Por conseguinte, preso graças ao artefato inventado - que em nossa comparação equivale ao pequeno $a$ no centro do nó borromeano - e não às diretrizes e parâmetros tecnocientificistas da psicopedagogia ortodoxa, o pêndulo educ $(a)$ tivo fica enlaçado e não despenca em renúncia porque, sem necessariamente procurar, acaba encontrando e fazendo precipitar, pelo lastro, o sustento de sua palavra, embora não tenha instrumento mais palpável, senão ético, que o seu bom senso para aferir se já passou ou não do ponto, exagerando ou omitindo-se, seja em permissividades ou elogios, exigências ou reprimendas, tarefa que pode ser bastante perturbadora, principalmente quando esta parece ser a tônica do que acontece, cotidianamente, nas dinâmicas com os educandos, seja um aluno em particular, seja uma classe inteira, da educação básica ao nível superior.

Em suma, o que parece emergir, muito acima do preparo pedagógico minimamente suficiente para o ensino de algum recorte da cultura humanamente acumulada, é que faz parte do trabalho do educador, ou melhor, dessa função, aprender a pendular, entre o desejo (da mãe?) e um Nome, como iremos daqui a pouco nos aprofundar, para não deixar esgarçar nem o próprio aparelho psíquico, nem o do educando - por conta do furor-pedagógico de todo dia -, embora isso sempre possa acontecer, já que, teoricamente, o educador almeja que o educando aprenda, motivo pelo qual se posiciona enquanto mestre.

\footnotetext{
${ }^{142}$ BERNFELD, S. Sisyphe ou les limites de l'education. Paris: Payot, 1925.

${ }^{143}$ HAMELINE, D. Les risques du métier, psychanalyse de l'enseignement. In: Attention! écoles. Paris: Fleurus , 1972, p. 243-265.
} 
A dificuldade, contudo, é que essa abertura relativa propiciada pelo estilo de endereçamento, assentado no pequeno $a$, deve ser perlaborada pelo adulto na função de educador de maneira diversa ao que se acostumou em torno da absorção dos dispositivos metodológicos de ensino. Talvez mais importante do que tentar aprender a ensinar, por exemplo, seja aprender a ter prazer em suportar as agruras e peripécias do aprender. Aprender a ter prazer, por exemplo, no exercício do formalismo procedimental e lógico para os cálculos matemáticos, ou na leitura atenta e bem pontuada de textos com conteúdo, sintaxe e vocabulário mais elaborados, senão no entendimento das interelações existentes em determinado contexto histórico, geográfico ou filosófico multifacetado, enfim, aprender a tirar prazer do rigor de pensamento, mas também da disciplina necessária à execução de certos procedimentos, para os quais, não raramente, uma boa dose de contenção pulsional precisará ser tentada.

- Quantas vezes ouvi e continuo ouvindo, como explicação à grafia ilegivel, ao texto desconexo, às respostas matemáticas sem justificativas, senão completamente absurdas que "este é o meu m", "este é o meu jeito de escrever", "este é o meu jeito de calcular"?... Então, meio irritada, com um tom que deve ser irônico, pergunto a eles coisas do tipo:

- E desde quando o " $m$ " é seu, assim como o " $a$ ", o " $b$ ", o " $t$ " ou o "l”?; ou

- E escrever mal, é o seu "jeito"?; ou

- Mas qual foi seu "jeito" de calcular, se ele nem sequer aparece aqui?

Ao que tudo indica, um tipo de fertilidade auto-sugestiva para o trabalho do educador/professor pode, com o tempo, ser adquirida pela invenção de subterfúgios éticos e estéticos que permitam usufruir daquela liberdade relativa do educador, de modo que, aos poucos, aprenda a fabricar uma bagagem particular e junto com ela certa independência relativa, frisamos, senão seria o mais-de-gozar - para agir de forma singular aos acontecimentos inesperados e impossíveis que surgem, impreterivelmente, na dinâmica com os educandos, inventando cotidianamente um repertório de "saídas", de atalhos, a serem arquivados "na manga" para, quando for o caso, tentar sacá-los novamente, pondo-os em ação, adaptando-os a cada ocasião, senão inventando outros - o que se mostra instigante -, na tentativa de buscar traçar variações semelhantes ao desvio angular impresso na areia, conforme as condições latitudinais em que o pêndulo esteja posicionado, isso que podemos transpor às variações contingenciais da situação educativa, já que o educador não pode prever, nem escolher o estilo da transferência que lhe será endereçada, e o que o seu aparelho psíquico fará com ela, em reação, em amódio de contra-transferência. É o savoir-faire que perlaboram, em nosso entender, profissionais da educação há anos em função, especialmente 
aqueles que não vivem sob a tortura de nunca estarem certos do que devem ou podem fazer e não fazer, falar e não falar, propor ou recusar, ofertar e exigir, desdobrando uma espécie de sabedoria bastante eficaz na lida com o alunado, todavia improvável de ser transmitida e replicada por parâmetros e manuais, quaisquer que sejam. É o que demonstra, por exemplo, a pesquisa publicada sob o título $O$ avesso do modelo: bons professores e a psicanálise, de Marcelo Ricardo Pereira (2003).

Através da análise de entrevistas com professoras do Ensino Fundamental tidas e havidas como "boas" por diretoras e supervisoras de ensino, o autor relata o que a nós parece ser da ordem de uma verdade íntima e que, talvez por isso, consiga traduzir bem o que tentamos argumentar até aqui. Ao sustentarem a posição de colocar em questão a formação teórica, optando por mediar o encontro com o aluno não tanto pelo saber-teórico, mas por um saber que "se aprende na prática" - um saber-fazer -, declaram que:

(...) a portas fechadas são donas de suas "salas", que entre elas e os alunos, "da porta para dentro", estabelecem-se outras leis que não são necessariamente as da instituição. Parecem falar de outro mundo. Um mundo em que são rainhas (ou reis - ainda que sejam mulheres) e fazem semblante de mães, pais, babás, conselheiras, amigas e possíveis outras aparências que só a prática lhes possibilita vivenciar. (...) De posse apenas da formação teórica, esses papéis talvez se ruiriam. É que na classe desenvolvem modelos únicos de trabalho docente que escapam ao previsto pela formação. São modelos que dizem mais de suas particularidades do que de um sistema universal de exercício ou de exemplo a ser seguido. Dentro de cada classe, genuinamente reinam seguindo modelos que criam e que se desvanecem tão logo são postos em prática. Se se perenizam, é por um descuido. A experiência lhes impõe essa exigência: a de criar modelos singulares, mesmo que se baseiem em modelos universais ou nas ações de outrem (PEREIRA, 2003, p.69).

Assim, embora fixo àquilo que, por dever adulto e profissional, o educador não pode não se pôr a ensinar da cultura humana construída e acumulada, seja pertinente ao currículo escolar, seja relativo aos padrões civilizatórios socialmente valorizados e necessários à sobrevivência minimamente sã do planeta e do homem, o educador acaba conquistando certa liberdade para girar sobre o próprio eixo, de acordo com o que causa o seu desejo em relação à cultura diante daqueles que estão ali posicionados para aprender (ou não), uma vez que encampou para si esse dever. Reconhecer o assento da barra do recalque - em última instância a própria castração - , convencendo-se de que o controle e as previsões assertivas não existem em relação ao sujeito, nem mesmo no campo pedagógico, talvez seja a condição primeira para que o educador possa começar a construir para si, antes mesmo que para o outro, em Nome-(im)próprio, a arte cavalheiresca do pendular entre Cila e Caribde, do permitir e do proibir, do premiar e do punir. 
- Palavra um pouco forte esse "punir", não...?

- O problema não está em punir ou não punir... o problema está, digamos, em sentir muito prazer em punir, mas denegar, já que a posição de educador, vira e mexe, sem que sejamos hipócritas, oferece essa possibilidade-arapuca, assim como a do agrado, a do elogio, igualmente perigosos, porque acenam com outra espécie de armadilha que é a do narcisismo. Lembremos: Cila e Caribde são monstros, não títeres... o punir, em certos acontecimentos, é aquilo que chama para ser lançado, embora jamais deva ser mantido junto ao corpo ou à palavra do educador... a arte de pendular vai se aprendendo assim, aos poucos, com generosidade e frieza, cálculo e aposta... menu de incertezas...

No entanto, resta uma dúvida lançada pelo colega Marcelo Ricardo Pereira: se o objeto pequeno $a$ é o um resto que se desprega e cai, como acontece com as fezes, com a voz, com o seio e o olhar, segundo Lacan, como mantermos ele ali, preso no girador que sustenta nada menos que o fio do educar, já que o $a$ pode ser, também, objeto mais-de-gozar, como apontou Lacan? Porque, talvez, esse seu escorrimento, ou seja, aquilo que escapa, que resta, possa não ser apenas os arroubos obssessivos e ortodoxos de Itardes e Schereberes, embora sem dúvida seja essa uma realidade, já que ambos foram inventores de controversas matrizes pedagógicas. Não obstante, com o objeto $a$ ali posicionado, no vértice por onde se sustentam os dois extremos do pendular educativo, também se pode encampar a invenção de trabalhos educativos e pedagógicos como os que inventam as Sullivans, prescindindo das prescrições metodopsicodidáticas, na tentativa de ajeitar suficientemente bem as coisas difíceis, quando elas se apresentam e nos põe em xeque na empreitada educativa, mesmo porque o embate com o educando nem sempre é sem riscos, nem consequências, caso contrário nossa jovem e quase cega educadora não teria literalmente perdido dois dentes por conta dos trabalhos iniciais com a pequena Helen, mas tampouco estaria aqui, novamente, a ser lembrada, depois de tanto tempo.

- Vez em quando, com os alunos, depois da vigésima explicação diferenciada sobre determinado assunto que, por algum motivo, não conseguiram, se recusam ou não se dispuseram ainda a entender, apesar de todas as cores de canetas que pude usar, da maior e mais clara caligrafia que me foi possível escrever, com a tonelada de paciencia explicativa que busco do fundo de minhas lembranças de estudante em dúvida, como muitas vezes também fui; enfim, depois de tudo isso - e não me venham dizer que é possivel esperá-los construir, pela própria experiência, certos conhecimentos como a conjugação dos verbos, os diversos tipos de fatoração, a lógica dos números irracionais, entre outros - , como um último recurso, apelo para uma frase, que na verdade é uma cena - um tanto clownesca - , inventada para ser ao mesmo tempo um pouco brava, um pouco estranha, que chega inesperadamente para eles, impossivel de ser reproduzida no texto escrito por incluir na prosódia e no gestual que lhe são característicos - e que varia de aluno para aluno, mas também de dia para dia - o conjunto de um olhar vesgo, arregalado, uma boca um pouco torta, em meneio de cabeça, envolto tudo numa voz que não é a costumeira, acrescida de um suspiro de desabafo e cansaço que, na verdade, são o que são, sinalizando estarmos a um passo de encerrar a partida por WO: "Agora eu entendi!, você está querendo me 
enlouquecer!" (sic) A risada quase sádica, depois de um breve silêncio suspenso no ar, acontece, impreterivelmente, como num momento de concluir, anuindo a interpretação. E então, recompostos do susto, já que eujemoi os pegou de surpresa, provavelmente, por ordem de meu furor pedagógico - logo que pedagoga Ana Carolina também é -, tento mais uma última e derradeira vez - a que geralmente funciona -, mesmo porque, se ainda não funcionar, esperamos pela aula seguinte, quando - se preciso for - , tudo há de ser recomeçado... Eis um pouco da arte de "fazer cantarem as pedras", como disse um dia, o professor do meu professor franco-argentino que, com certeza devia saber bem o pendular, não só dos educadores, mas também das locomotivas e vagões... 


\section{Pintura}

Sempre compreendo o que faço depois que já fiz.

O que sempre faço nem seja uma aplicação de estudos. É sempre uma descoberta. Não é nada procurado. É achado mesmo. Como se andasse num brejo e desse no sapo. Acho que é defeito de nascença isso. Igual como a gente nascesse de quatro olhares ou de quatro orelhas. Um dia tentei desenhar as formas da Manhã sem lápis. Já pensou? Por primeiro havia que humanizar a Manhã. Torná-la biológica. Fazê-la mulher. Antesmente $\mathrm{Eu}$ tentara coisificar as pessoas e humanizar as coisas. Porém humanizar o tempo! Uma parte do tempo? Era dose. Entretanto eu tentei. Pintei sem lápis a Manhã de pernas abertas para o Sol. A manhã era mulher e estava de pernas abertas para o sol. Na ocasião eu aprendera em Vieira (Padre Antônio, 1604, Lisboa) eu aprendera que as imagens pintadas com palavras eram para se ver de ouvir. Então seria o caso de se ouvir a frase pra se enxergar a Manhã de pernas abertas? Estava humanizada essa beleza de tempo. E com os seus passarinhos, e as águas e o Sol a fecundar o trecho. Arrisquei fazer isso com a Manhã, na cega. Depois que meu avô me ensinou que eu pintara a Imagem erótica da Manhã. Isso fora.

Manoel de Barros

Memórias Inventadas: A Segunda Infância 


\title{
5. Os extremos da função pendular do educador
}

\author{
Somos o intervalo entre \\ o nosso desejo e aquilo \\ que os desejos dos outros \\ fizeram de nós
}

Fernando Pessoa

Faz-se necessário esclarecer o uso que compartilhamos neste trabalho do termo função, porque difere daquilo que, comumente, entende-se por seu carácter funcionalista, ou seja, como sinônimo de "papel a desempenhar", "obrigação a cumprir”, "profissão/ofício", "exercício", "utilidade". Não. Função aqui remete ao que, pelo paradigma do estruturalismo $^{144}$ utilizado por Lacan ${ }^{145}$, constitui-se como lugar vazio inscrito no discurso, com valor relativo em relação a outros elementos no interior de um sistema, de uma estrutura. Mas o que se entende, nesse paradigma, por uma estrutura?

Segundo Kamers (2005, p. 80), uma estrutura é um conjunto de elementos regidos por lei(s) própria(s), independente da lei que rege cada elemento, em separado, que a compõe. Devido a isso, em uma estrutura, a alteração de qualquer elemento do conjunto determina alterações em todos os outros, o que faz com que ela esteja sempre sujeita a sofrer transformações imprevisíveis e incontroláveis. Ao cumprir uma função dentro do sistema,

\footnotetext{
144 "Este paradigma põe em xeque a perspectiva de progresso própria à concepção evolucionista, introduzindo um pensamento de ruptura, (des)construtor do humanismo, do existencialismo e do historicismo. (...) é um paradigma constituído pela articulação e dissociação críticas de pensamentos no interior de diversas disciplinas. (...) justamente no período em que a Europa vive um momento de vanguarda e crença no progresso [década de cinquenta], o estruturalismo surge abalando seus alicerces, apontando para o descentramento, para a ruptura com a noção de consciência, ressaltando a dimensão do inconsciente e seus avessos. (...) Ao romper com o historicismo, o humanismo e o existencialismo, o paradigma estruturalista se constitui como um campo de confronto que se revela no interior das ciências humanas, no intuito de aplicar às ciências do homem as categorias das ciências da natureza, permitindo reduções científicas, portanto, universais. Nesse sentido, o estruturalismo não designa um objeto específico, mas é um termo indispensável para englobar um certo tipo de atividade e uma certa forma de linguagem, já que o estruturalismo não é uma filosofia, mas engloba várias filosofias que se explicitam de um modo contraditório" (KAMERS, 2005, p. 72-74, acréscimo nosso).
}

145 Lacan retomou os conceitos capitais da psicanálise freudiana a partir do estruturalismo linguístico de Saussure, da antropologia estrutural de Lévi-Strauss e da fonologia de Jakobson, na tentativa de reverter a dimensão psicologizante que foi tomando a leitura dos textos de Freud e a terapêutica da psicanálise em si. Na exposição de 8 de julho, de 1953, sobre "O simbólico, o real e o imaginário", o próprio Lacan situou essa trajetória sob o signo de um retorno aos textos freudianos, iniciado em 1951. Elizabeth Roudinesco (2008, p. 290) qualifica esse gesto como uma valorização ortodoxa do freudismo, o que permitiu a Lacan, já naquele ano, com "Função e campo da fala e da linguagem em psicanálise", estabelecer uma verdadeira teoria estrutural da terapêutica psicanalítica, que até então não existia. 
cada elemento detém um valor de acordo com a forma que se relaciona, ou melhor, que se opõe, que se distingue , dos demais elementos, e não conforme suas propriedades intrínsecas, motivo pelo qual o valor de uma função é sempre relativo, e não absoluto. É o que ocorre, por exemplo, com os algarismos e os valores relativos que eles assumem no sistema decimal. O algarismo 3 só representa 3, em módulo ou valor absoluto, quando está posicionado na casa das unidades simples do conjunto dos números inteiros, não em outra. Caso esteja posicionado na posição das dezenas, representará 30, na de milhar, 3.000 e assim por diante. $\mathrm{Na}$ análise sintática podemos verificar o mesmo, por exemplo, quando determinado substantivo, em uma oração, tem a função sintática de núcleo do sujeito - A bola é de Raul - , enquanto em outras orações, o mesmo substantivo, pode ter valor de núcleo do objeto direto - Raul pediu-me a bola - , ou de predicativo do sujeito - Raul é uma bola - , entre outros, o que demonstra que, na estrutura de uma oração, a função sintática de cada termo depende das relações que o mesmo guarda em relação aos demais, significado que só se precipita depois da última palavra da oração, esta que funciona como ponto de capitonê, portanto de amarração do que foi transmitido. Na estrutura discursiva de uma família, não é diferente. O pai, apesar de biologicamente homem e genitor do filho, bem pode cumprir a função do desejo da mãe e simbolicamente figurar como uma enorme boca de crocodilo para o filho, em lugar de efetivar o Nome-do-Pai ${ }^{146}$, conforme esteja posicionado, em termos significantes, em relação ao filho e também em relação à mãe deste. Ou seja, o valor da função paterna não é dado pela genitalidade do genitor, que é uma característica do homem real, nem porque ele tem como função social ser o marido da esposa que é a mãe de seus filhos, mas por uma confluência de fatores estruturais discursivos no seio daquela família, ou seja, do lugar que sua palavra é tomada (ou não) pelos demais elementos daquela estrutura. A função paterna só acontece, digamos, quando a palavra do pai real (ou do tio, do irmão, da avó, do padrasto, da própria mãe, entre outras possibilidades), dentro daquela estrutura familiar, tem o valor simbólico do pai que interdita o incesto.

No capítulo anterior, discorremos sobre aquilo que, analogamente, representamos como ponto de sustentação do pendular educativo - o estilo de endereçamento da palavra do educando ao educador, assentado no objeto $a$, objeto causa de desejo, que não deixa de ser, em última instância, desejo de saber sobre o sexo e a morte, ou seja, desejo de saber, através do Outro, o que se pode fazer de interessante na vida antes de se chegar àquela -, espécie de vértice para o ângulo que se forma na amplitude da trajetória pendular, demarcada por dois

\footnotetext{
${ }^{146}$ Nome-do-Pai: Segundo Roudinesco e Plon (1998, p. 541), termo criado por Jacques Lacan em 1953 e conceituado em 1956, para designar o significante da função paterna. Voltaremos a ele no item subsequente.
} 
extremos, que nada mais são do que o ponto em que a velocidade do pêndulo torna-se nula e a energia cinética se transforma em energia potencial, para em seguida inverter o movimento.

- Imagem interessante, porque é como se, ao chegar num desses extremos, na verdade Cila e Caribde, o educador ficasse suspenso no ar, por um breve tempo, tempo, talvez, de não fazer nada, tempo de estancar, de dar tempo ao tempo à própria função que, pela estrutura mesmo, impõe uma inversão se o educador não cair na armadilha de ficar, imaginariamente, preso ali, seja no desejo-do-pedagogo, seja no Nome-(im)próprio, estes que são, também, vetores de alienação e de separação simbólica. Porque caso fique ali, num extremo ou em outro, aprisionando o pendular, terá construído um patamar para pousar, impedindo que o pêndulo volte a "cair", na direção do ponto para o qual a força da gravidade sempre tenderá a levá-lo, o ponto de equilibrio, que se acontecer, é o fim do pendular. A posição de repouso. Pelo visto, a função pendular do educador não está dada ao repouso, a menos que venha operar aquela renúncia educativa, descrita por um tal Lajonquière ${ }^{147}$. Tarefa um tanto cruel a do educador, sendo assim, por que há tantos os que se oferecem para ocupá-la?... ${ }^{148}$

Para os extremos desse contínuo pendular do educador havíamos atribuído, a princípio, os nomes de função materna e função paterna, o que logo depois foi reformulado, por sugestão e explicação de nosso orientador, para desejo-da-mãe e nome(s)-do-pai. Ficamos com eles até o início destas sínteses finais, quando durante o escrito não foi mais possível sustentá-los. Tomamos então da liberdade de mudá-los, de forma que permitissem a descolagem necessária entre as figuras parentais e a figura do educador, que pode sim, ser desde um extremista - o pedagogo obsessivo ortodoxo - , até uma pessoa "comum", que ensi(g)na, sem maiores comprometimentos com a causa "pedagógica", digamos assim, por isso também outro extremista. Por conta disso os pontos de suspensão pendular ficaram nomeados, ao menos por enquanto, desejo-de-pedagogo e Nome-(im)próprio, o que nos resta, por fim, tentar explicar.

\footnotetext{
${ }^{147}$ LAJONQUIÈRE, L. . Dos 'erros' e em especial daquele de renunciar à educação. Estilos da Clínica (USP), São Paulo, v. 2, n. 2, p. 27-43, 1997.

148 Comumente, durante o trabalho com os alunos que procuram pela minha orientação de estudos, ao "pedir" que façam determinadas coisas que eles definitivamente não estão dispostos, costumo falar: "Fulano, aqui a professora sou eu, quando você for professor, poderá escolher o que seus alunos deverão fazer, mas aqui, não, aqui quem coloca a música na vitrola, sou eu!”. A reação é sempre de denegação, nunca de aprovação . "Eeeeeu??!? Professooooooor??!?!, NUUUUNCA vou querer ser professor!"... como se essa fosse uma profissão menor, ou nojenta - pois a cara que fazem é de asco - , incapaz de um mínimo atrativo. Então penso, e às vezes falo, "Imagina se você aguentaria, caso fosse professor, um aluno como você e seus amigos, em turma?"...e então não há como não rirmos, porque também eu, quando adolescente, era também terrível e jamais pensei que viria a ocupar profissionalmente esse lugar, embora pelas vicissitudes da vida me encontre nele desde 1982, também meio sem-querer-querendo ...
} 


\subsection{Da função materna ao desejo-de-pedagogo}

A fim de indicar o que do nosso ponto de vista tem de semelhante entre a função materna e a do educador, trazemos aqui uma série de considerações a respeito da função da mãe que entendemos passíveis de serem reeditadas em outros cenários e tempos, especificamente quando não se trata mais da primeira educação sofrida por um sujeito, encampada pelas figuras parentais, mas por outros agentes implicados na oferta de recursos discursivos capazes de dar continuidade aos processos de construção, constituição e formação do educando, para enfim, no item subsequente, fazermos o mesmo em relação à função paterna.

No entanto, vale aqui uma pergunta. Caberia mesmo afirmar que uma das funções do educador seja, também, convergir para a constituição do sujeito, quando parece que o aparelho psíquico tenha sua estruturação na primeira educação, ou seja, na educação iniciada pelas figuras parentais, em meio ao seio familiar?

Duas vezes, sim.

Primeiramente, na educação terapêutica ${ }^{149}$, quando o educador/agente de linguagem ${ }^{150}$ é chamado para ajudar a resgatar a subjetivação de uma criança com falhas na estruturação psíquica e tentar construir, com ela, recursos simbólicos capazes de agenciar as operações de alienação e separação que só podem ser feitas caso o educador exerça, para o suposto sujeito, a função de Outro, não apenas no sentido de nomeação (de acontecimentos e objetos, por exemplo), mas no sentido de instaurar o mecanismo próprio do registro simbólico, para que venha a deslizar nos significantes e deixe de se aprisionar no lugar de objeto em relação ao outro, de onde são produzidas, por exemplo, as estereotipias (cf. BRAGA, in COLLI, 2005, p. 43-64); E em segundo lugar, nas empreitadas educativas costumeiras, ou seja, não havidas como "especiais", em que o educador colabora para que o processo do recalque chegue a se completar, ideia desenvolvida por Robert Lévy, ao defender que o simbólico na criança só se desenvolve muito lentamente.

\footnotetext{
149 A educação terapêutica é uma prática clínica e educacional para crianças com transtornos globais de desenvolvimento.

${ }^{150}$ Agente de linguagem, termo cunhado por Renata Petri (2003) para designar os profissionais que se ocupam do tratamento de crianças com transtornos do desenvolvimento, capazes de dirigir-lhes demandas e também nutrir-lhes um desejo.
} 
(...) o conceito psicanalítico de infantil apresenta o grande interesse de situar a criança na época de sua constituição psíquica "na espera" de um recalque completo, que possa se produzir, ou não, de outro lugar. Mas, se os neurofisiologistas conduzem as representações do infantil para a imaturidade, a psicanálise transmite, pelo vocabulário dos clínicos, o conceito de regressão; o conceito de infantil não é assim uma representação da regressão (o que supõe uma progressão), mas um ponto de vista dinâmico do momento constitutivo do aparelho psíquico da criança com a especificidade das produções que isso acarreta do ponto de vista das produções do sintoma (LÉVY, 2008, p. 19, grifo nosso).

Segundo Kaufmann (1996, p. 446), o conceito de recalcamento (Verdrängung) na concepção freudiana não tinha originariamente outra função além de dar uma base, na estrutura do sujeito, ao fenômeno da resistência manifestado durante a intrepretação analítica, quando o paciente se recusava a exprimir seu desejo - sendo esta a manifestação da "resistência". Por outro lado, Hanns (1996, p. 363) afirma que "psicanaliticamente, verdrängung consiste em afastar da consciência algo que se manifesta e cuja satisfação geraria desprazer".

Verdrängung é habitualmente traduzido por "recalque" ou "repressão". O verbo verdrängung genericamente significa "empurrar para o lado", "desalojar"; também pode ser empregado de modo mais específico para designar a ação de "deslocar massa de água ou outro volume qualquer"(por exemplo, ao passar, o avião desloca grande volume de ar [ou um navio, que desloca grande volume de água] ). Conotativamente, verdrängung remete a uma sensação de "sufoco", de "incômodo", que leva o sujeito a desalojar o material que o incomoda. Contudo, apesar de ter sido afastado, tal material permanece junto ao sujeito, pressionando pelo retorno e exigindo a mobilização de esforço para mantê-lo longe. Tais conotações coincidem, grosso modo, com aspectos do emprego do termo no contexto psicanalítico (HANNS, 1996, p. 355, acréscimo nosso).

De acordo com este autor, o mecanismo de recalque, em Freud, pressupõe a existência de uma clivagem, uma separação, entre consciente e inconsciente, entretanto, antes que essa diferenciação ocorra, as exigências pulsionais são rechaçadas por outros mecanismos mais arcaicos, como a transformação da representação pulsional em seu contrário, ou fazendo voltar a ação da pulsão contra o próprio sujeito (Idem, ibidem, p. 365) . O momento fundante do processo de recalque propriamente dito Freud designou por Urverdrängung, ou seja, acrescentando o prefixo ur-, utilizado para designar a ancestralidade e o fato de ser o primeiro de uma linhagem. Assim, 
A Urverdrängung é um recalque-primeiro a partir do qual se seguem todos os outros recalques, esses que Freud chamou de "recalques propriamente ditos". O "recalque propriamente dito" seria então "recalque posterior" ou "recalque a reboque", também chamado por Freud de Nachdrängen. A palavra nachdrängen, empregada por vezes em lugar de verdrängung, contém o prefixo nach-, o qual, nesse contexto, expressa a idéia de acréscimo, indica que um ato drängen (pressionar, empurrar), se segue a outro, e assim sucessivamente, formando uma série. (Idem, ibidem, p. 365-6).

Por que e como ocorrem esses primeiros recalque originais, afirma Hanns, é dos pontos mais complexos. Freud se indagou a respeito, sugerindo que o recalcamento original fosse um primeiro aprisionamento, no sentido de ligação, de uma representação (ideia) a uma energia pulsional, devido ao perigo que a realização pulsional coloca para o sujeito. Esse desejo não satisfeito permaneceria imanente e, a partir daí, exerceria atração para novas representações substitutas, que, também recalcadas, a ele conectar-se-iam, e assim consecutivamente, formariam uma extensa malha ou cadeia de representações interligadas (idem, ibidem, p. 365-6).

Não podendo haver fuga da pulsão, e na medida em que a pulsão não possa ser satisfeita, instala-se uma situação precária. O recalque é um estado que exige grande empenho de força para se manter, pois a pressão pelo retorno é constante (Idem, ibidem, p. 364).

Vejamos o que Roudinesco e Plon trazem em complemento para o nosso raciocínio:

Constitutivo do inconsciente, o recalque se exerce sobre excitações internas, de origem pulsional, cuja persistência provocaria um excessivo desprazer. [Contudo] O recalque não lida com as pulsões em si, mas com seus representantes, imagens ou ideias, os quais, apesar de recalcados, continuam ativos no inconsciente, sob a forma de derivados ainda mais prontos a retornar para o consciente, na medida em que se localizam na periferia do inconsciente. $\mathrm{O}$ recalque de um representante da pulsão nunca é definitivo, portanto. Continua sempre ativo, daí um grande dispêndio energético. (...) [assim] o recalque constitui, para a pulsão e seus representantes, "um meio termo entre a fuga (resposta apropriada às excitações externas] e a condenação (que seria o apanágio do supereu). [Freud distingue então] três tempos constitutivos do recalque: (1) o recalque propriamente dito, ou recalque a posteriori; (2) o recalque originário; e (3) o retorno do recalcado nas formações do inconsciente (ROUDINESCO ; PLON, 1998, p. 648, acréscimos nossos).

O retorno do recalcado, que na teoria freudiana corresponde ao terceiro tempo do recalque, manifesta-se não só sob a forma de sintomas, mas também de sonhos, esquecimentos, atos falhos e chistes. Guardemos isso. Vejamos o que pudemos acrescentar de Pierre-Christophe Cathelineau:

O recalcamento originário é o afastamento de uma significação, a qual, em virtude da castração, não é aceita pelo inconsciente: a significação simbólica 
suportada pelo falo, objeto imaginário. Posteriormente, intervém o recalcamento propriamente dito, o recalcamento das pulsões oral, anal, escópica e invocante ${ }^{151}$, ou seja, de todas as pulsões ligadas aos orifícios reais do corpo. O recalcamento originário as arrasta consigo, ao sexualizá-las. Exige que sejam postas de lado (Pierre-Christophe Cathelineau, in CHEMAMA ; VANDERMERSCH, 2005, p. 327).

Atentemos agora para o avanço teórico de Lacan, que obviamente nos interessa, porque desemboca no pequeno $a$ e na questão do estilo, utilizado por nós para vetorizar o vértice de nosso modelo pendular:

As incitações pulsionais provêm principalmente dos orifícios reais do corpo. Sejam elas a pulsão oral, anal, escópica ou invocante, são todas "a favor, diz Lacan, do traço anatômico de uma margem ou de um bordo: lábios, "inserção dentária", margem do anus (...), até mesmo a concha da orelha." Freud ainda fala de incitações pulsionais, quando evoca essas cadeias de ideias, sinais de uma excitação orgânica, aspiradas a posteriori, pelo efeito do recalcamento originário. O recalcamento originário leva-os consigo, sendo ao mesmo tempo recalcadas, como se fosse um "golpe de lâmina", dado pelos sentidos nos orifícios corporais, suportes da excitação (Idem, ibidem, p. 328).

Segundo o autor, se admite-se , de acordo com Freud, "o primado do genital”, isto é, o fato que a "fixação" desse objeto imaginário, o falo, exige o recalcamento de todas as outras pulsões à medida que se sexualiza, pode-se admitir que o representante originalmente recalcado, do qual Freud fala, seja precisamente o falo.

Ele é o único objeto para o qual, apesar da existência do pênis, não existiria um suporte real. Ele exige, em um a posteriori lógico, o recalcamento propriamente dito. Doravante, as pulsões não genitais são relacionadas ao gozo representado pelo falo. Ele as sexualiza e as leva consigo, em sua colocação de lado. Apela para sacrifício do gozo, seja qual for o objeto. (Idem, ibidem, p. 328).

Entao Cathelineau pergunta ao leitor, em virtude de quê ocorre esse "sacrifício de gozo"? Responde: em virtude do sentido, um sentido unívoco de ser fálico e suportado pelo significante, seja ele uma palavra, uma frase, uma letra - um diagnóstico médico ou psicopedagógico, queremos crer, no campo educativo, especialmente no escolar em tempos de hegemonia psicopedagógica.

$\mathrm{Na}$ clínica psicanalítica, exeplifica o autor, a emergência na vida psíquica de uma incitação pulsional encontra automaticamente, segundo Melman (Séminaire sur la névrose obsesionnelle, 1989), "uma lâmina que a barbearia (...), que exige que renuncie a essa incitação pulsional, [para] que se torne inofensiva, anulada, transformada, desviada,

\footnotetext{
${ }^{151}$ Pulsão invocante é a que tem por objeto a voz.
} 
sublimada ou ainda, se tiver de ser realizada, isso só poderia ocorrer em certas condições, para que eventualmente disso resultasse o prazer" (acréscimo nosso).

- ...Prazer de aprender, por exemplo, e conseguir obter os resultados satisfatórios que a escola tem a oferecer, em lugar do fracasso?

- Siiiiiimmmmm... prazer de aprender... de aprender também a lidar com a incitação pulsional em meio ao cenário escolar, por que não?...

Isso também explica por que essa incitação não pode retornar na cadeia falada, a não ser como obscenidade, isto é, porque os significantes que se apoiam no recalcamento do falo podem se transformar, mesmo que a consciência tente evitá-lo, em signos de obscenidade.

Pelo recalcamento, o sujeito sacrifica todo gozo. O objeto imaginário, o falo, que significa o gozo, é posto de lado, em virtude do significante, e o sujeito sacrifica a ele todas as suas incitações. Finalmente essa aspiração das incitações pulsionais pela significação fálica colocada de lado, como também a simultânea sexualização dos significantes a ela ligados, nas diferentes pulsões, poderá muito bem se produzir sem a intervenção da função paterna. $\mathrm{O}$ recalcamento por um efeito de sentido que a criança relaciona com os enunciados significantes (Idem, ibidem, p. 328-9).

Mas, como apontou Robert Lévy, se os neurofisiologistas conduzem as representações do infantil para a imaturidade, enquanto a psicanálise transmite o infantil como ponto de vista dinâmico da constituição psíquica da criança, talvez seja possível rever a prática discursiva hegemônica, compactuada ao discurso universitário no campo escolar, disso que nos parece também sintomático, porque abriga o estancamento do funcionamento pendular do ato educ(a)tivo, fixando-o, aprisionando-o, educador e educando, no extremo do desejo-do-pedagogo, assentado na verdade de saberes médico e psicopedagógicos estabelecidos, isso que talvez nomeemos como furor diagnóstico. Assim, então, quando "Pedrinho"152 - adjetivado como imaturo, ou portador de necessidades educativas especiais com direito legal a todo leque de condições também "especiais" de avaliação e prazos - vier sem as lições de casa da semana porque, mais uma vez "esqueceu" de anotá-las na agenda ${ }^{153}$,

\footnotetext{
152 "Pedrinho" é uma espécie de personagem-passageiro dessa nossa linha de pesquisa, ou melhor, desse nosso trem de locomotivas e vagões.

153 Aqui poderíamos encaixar um enorme menu de outras justificativas, do tipo: porque não tenho agenda; porque perdi a agenda; porque roubaram minha agenda; porque não gosto de usar agenda; porque eu não uso agenda; porque não sei usar agenda; porque não costumo olhar a agenda; porque não ouvi que era para anotar as lições na agenda; porque a agenda ficou no armário da escola; porque deixei a agenda embaixo da carteira; enfim, uma cantilena que não tem fim, embora as justificativas pudessem também mudar de tema: porque não tive tempo; porque .... não sei por quê; porque tive que sair com a minha mãe para ir ao dentista, ao médico, ao futebol, ao shopping ; porque passei mal; porque não entendo o que eu tenho que fazer; porque a professora não explica a matéria; porque me deu um branco; porque esqueci o livro na escola; porque perdi o livro; porque roubaram o livro; porque não sei onde foi parar o meu caderno; porque esqueci meu material no carro do meu
} 
como a maioria de seus colegas tiveram que fazer, com grande dose de paciência e resignação para, depois em casa, forçosamente, abdicarem parte de seu tempo frente à televisão, às redes sociais da internet, ao soninho depois do almoço, às atividades esportivas, ou ao dolce far niente, dedicando esses preciosos tempos aos seus deveres escolares, já que, de alguma forma, metaforizaram não serem mais o falo de suas mamães - e, às vezes, dos papais bem, se nesse momento, ao invés de tomar essa conduta como diferente ou imatura quando na verdade, na maioria dos casos, parece ser um posicionamento subjetivo do educando frente ao que representa a instituição escolar, o educador, o professor, enfim - bem, então talvez seja possível averiguar que, mais uma vez, "Pedrinho" está apenas gozando com seu infantil, na espera do que provavelmente ainda tem em casa, o seio da mãe, ou coisa que o valha, que agora poderá vir em formato de uma grande e portentosa "mamadeira pedagógica"154 : poderá fazer as provas fora do tempo regulamentar, em sala separada do restante da turma; substituir algumas provas por trabalhos feitos em casa; levar a prova para fazer em casa; contar com uma avaliação mais condescendente com os diagnósticos médicos apresentados à direção da escola; ter um coleguinha para escrever na sua agenda as tarefas para o dia seguinte; e ser chamado para todas as recuperações a que tem direito, mesmo que no final do ano letivo o conselho de professores acabe, ainda, sendo forçado a compor as suas notas para uma aprovação que encontra embasamento nos direitos da criança e do adolescente. Eis assim, uma nova modalidade do cenário escolar: uma pequena legião dos alunos encaixados nos casos de inclusão. Mas não na Lei. Porque frente a esta, "Pedrinho" faz semblante de desentendido, pondo-se de lado, mamando agora na grande teta da escola "especial". Isso que é uma reivindicação cada vez mais recorrente e ameaçadora utilizada pelos próprios pais!

Em suma, uma coisa é o educador entender que "Pedrinho" não consegue atingir os resultados mínimos em sua escolarização por conta de ser, ainda, "muito imaturo para a idade", ou "diferente", porque supostamente carrega algum tipo de déficit no funcionamento psicológico ou neurológico; outra, bem diferente, é o educador poder reconhecer nessa profusão sempre mais ou menos igual de justificativas educandas, o significante de um posicionamento específico no interior da estrutura escolar, em última instância um posicionamento obsceno e inaceitável, porque vindo do infantil que insiste em denegar a

pai; porque eu tava com sono; porque eu estou cansado; enfim, uma lista infinita de porquês.... E por que, não? Porque, sim!

${ }^{154}$ Esta foi uma expressão cunhada por nosso orientador, proferida em aula de graduação, nos idos de 2004, se não me falha a memória. Como não temos conhecimento de tê-la escrito ainda em nenhum texto, entendemos justo fazer-lhe a referência, mais uma e uma vez... 
castração e o incesto, apesar de "Pedrinho" ter já 7, 12 ou 17 anos de idade, senão 23, nas classes do ensino superior onde, por incrível que pareça, não é incomum a demanda pela (nada)boa e costumeira "mamadeira universitária"155.

Bem, por este viés, torna-se possível admitir que a função do educador seja também a de convergir para a constituição subjetiva, mesmo pós a educação primordial, na medida em que possa trabalhar a favor da integração de um recalque completo da sexualidade infantil, já que uma série de funcionamentos tidos como "imaturos", ou "deficientes", podem, senão deveriam passar a ser considerados sintomáticos, uma vez que o esquecimento infantil como apontou Freud em A Psicopatologia da Vida Cotidiana - dá meios de compreender as amnésias que estão na base da formação dos sintomas neuróticos. Ou seja, "Pedrinho" não é exatamente um "imaturo" que com o tempo irá "amadurecer" e ficar bem, não, talvez seja mesmo uma criança, ou jovem, caminhando à deriva para cristalizar uma neurose que poderá acarretar, futuramente, distúrbios de personalidade. A escola e a pedagogia não-ortodoxa tem alguma coisa a ver com isso? Nós entendemos que sim, afinal, é nos anos iniciais de uma vida que aprendemos a funcionar psiquicamente de algum jeito, e se é dentro da escola que as crianças, até uma parte da adolescência, são postas pelos adultos “em quarentena" até que tenham condições mínimas para o convívio social em meio adulto, ou melhor, até que se configurem como sujeitos de um aparelho corporal e psíquico razoavelmente operável para a vida em sociedade, não tem como a escola não estar atenta às vicissitudes e idiossincrasias da constituição psíquica, cujo limite é o tempo, não muito curto, mas duplo, lógico e cronológico.

Desde o início de sua obra, Freud define sintoma como a etapa final da doença; é uma função de compromisso resultante de um conflito que resultou numa defesa mal-sucedida. O que é para ser recalcado se impõe ou retrocede. O problema todo é então colocado em termos de capacidade do recalque em exercer seu papel. Freud distingue dois períodos da vida: 8 a 10 anos e de 13 a 17 anos, aproximadamente, que são os momentos de transição durante os quais o recalque geralmente se produz (LÉVY, 2008, p. 58).

E como o educador compactuaria com essa necessidade constitutiva do psiquismo subjetivo de levar que o recalque completo seja, finalmente, possível? Agindo em favor da Lei da proibição do incesto, ou seja, fazendo uso dela, que representa o Nome-do-Pai, o não-do-pai, capaz de intervir como mediação, artifício e recurso, permitindo ao sujeito

\footnotetext{
${ }^{155}$ Nas seguintes modalidades, a título de exemplos: oportunidade para fazer novamente uma avaliação em que teve baixo rendimento acadêmico; não haver prova, apenas trabalhos feitos em casa; copiar ou comprar trabalhos prontos pela internet e não ser punido por isso; complementar as baixas notas que obteve com trabalhos suplementares não previstos; atribuição de notas que garantem a aprovação do aluno, mas não correspondem à qualidade tacanha da produção discente, enfim...
} 
encontrar na ordem simbólica aquilo com o que estruturar e abrigar sua sexualidade enquanto desejo (cf. Idem, ibidem, p. 62). O que, no modelo pendular, indicaria ir em direção ao extremo do Nome-(im)próprio, como um pouco mais à frente iremos argumentar.

Mas enfim, retornando aos nossos propósitos, qual a função de uma mãe?

Oferecer os cuidados reais básicos como alimentar, vestir, cuidar da higiene, da saúde, da segurança, colocar para dormir, entre outros costumes da puericultura?... Não, pois o que se sabe é que, por vezes, apesar de todos os cuidados ideais disto que compõe a maternagem, não figura em corpo presente aquela que encena, no campo da linguagem e da palavra, a função materna, embora esta comporte os tais cuidados por implicar, inicialmente, uma relação corporal com a criança, como afirma Kamers (2005, p. 172). É o que vem demonstrando, há algum tempo, a psicanálise com bebês e crianças que apresentam transtornos graves, quando se verifica uma falha na função materna, mais precisamente no oferecimento simbólico de um lugar singular e privilegiado para a criança no desejo da mulher como mãe, isso que se mostra fundamental, embora não garantidor, da estruturação subjetiva nos tempos da primeira educação, pois uma falha na função paterna também acarreta estragos.

$\mathrm{Na}$ função materna, uma mãe sustenta para seu bebê o lugar do Outro primordial. "Impelida pelo desejo, antecipará em seu bebê uma existência subjetiva que ainda não está lá, mas que virá instalar-se justamente porque foi suposta" (KUPFER, 2001, P. 49). Foi o que exemplificamos, no "diálogo" entre mãe-bebê, no início deste escrito: embora o bebê não fale, ela já fabrica para ele perguntas $\mathrm{e}(\mathrm{m})$ respostas, às quais ela mesma põe-se a tomar como demanda e respondê-las com seu saber. Dessa forma, por supor que exista mais do que um amontoado de órgãos, neurônios e carnes inconclusos, em franco desenvolvimento, fala ao bebê como a um sujeito de iguais capacidades assimilativas no campo da palavra, adaptando a fala adulta na prosódia do manhês - sempre singular - , muito provavelmente utilizando recursos inconscientes da infância que teve, ou senão, que fantasia ter tido ou querido. Por isso, quando está na maternagem, não a opera de maneira frugal, seca, nem psicotécnica, mas pelos transbordamentos daquele diálogo "louco", em que funde e encena ambas as falas, na primeira e na segunda pessoas, meio juntas, sobrepostas, atribuindo significantes mestres no trocar de fraldas, na alimentação, no banho, metaforizando gestos e barulhos muitas vezes involuntários do bebê, metamorfoseando-os em algo "querendo ser dito", antecipando que sua cria, com aqueles esperneios ou movimentos oculares, labiais, de mãos, "expressões" físionômicas, etc, esteja necessitando, querendo, pedindo, demandando 
alguma coisa, por mais amorfas ou indefinidas que pareçam a terceiros as tais manifestações, reflexas ou não.

Este saber atribuído ao bebê é o que permite ao Outro materno exercer sua necessária loucura cênica: a de deixar-se transbordar pelo bebê, colocando-se no lugar dele e falando, brincando, respondendo como se fosse ele. A loucura consiste em que a mãe fala, brinca ou responde como o bebê (antecipando-o como sujeito) e como ela própria (supondo que seu bebê entende o que ela quer lhe perguntar). Confirma-se assim, felizmente, um diálogo "maluco" (desde que ficcional) em que o Outro materno se coloca na posição do recém-chegado e dali interroga a sua posição de mãe. É ela quem responde à sua própria demanda fingindo ser o bebê. Trata-se aqui de uma dupla negação simbolizante: por um lado o Outro (materno) nega seu lugar e se coloca na posição do bebê e, pelo outro, nega e desloca o lugar do bebê para, ocupando essa posição, falar para a mãe que obviamente é ela própria (ocupando e negando ambos os lugares), num diálogo invertido, ficcional, "louco" e fundador (LEVIN, 2005, p. 33).

Sendo assim, uma mãe não toma toda essa "produção" corporal como meros efeitos fisiológicos de um organismo em crescimento, ela os toma como se fossem significantes, lançando e laçando seu filho em meio ao campo da linguagem e da palavra. E por que algumas mães fazem isso, até com certa tranquilidade e divertimento, enquanto outras simplesmente não conseguem?

Uma das versões que Lacan dá para a mãe é a de que ela é insaciável e ameaçadora por seu poder sem lei. Esta insaciabilidade refere-se ao modo próprio de a mulher tentar tamponar a falta, substituindo o falo pelo filho, operação que vai fracassar, pois vai sempre haver um resto irredutível de insatisfação (FARIAS ; LIMA, 2004, p. 21).

Para a mãe, a criança, longe de ser apenas a criança, é também o falo. Ao tomar este valor de falo, ela se identifica com o significante do desejo materno. (...) $\mathrm{O}$ falo, Lacan o demonstra, não deve ser confundido com $\mathrm{o}$ pênis. Tem uma função decisiva, que parece ser mais relevante para as mulheres que para os homens. Seguindo o percurso freudiano, ele indica o fato de, entre as faltas de objetos essenciais para a mulher, estar o falo, estreitamente ligado a sua relação com o filho: "Se a mulher encontra na criança uma satisfação, é, muito precisamente, na medida em que encontra nesta algo que atenua, mais ou menos bem, sua necessidade de falo, algo que a satura" (LACAN, 1957, p. 71) (FARIAS ; LIMA, 2004, p. 19).

"Mais ou menos bem", porque a criança que nasce, sempre chega meio fora de foco em relação àquilo que, inconscientemente, a mãe e o pai projetam para ser um filho ideal, o que encontra seu exemplo máximo no nascimento de bebês com comprometimentos neurológicos ou físicos sérios, como a síndrome de Down, a surdez, ou mesmo algum comprometimento adquirido como a paralisia ou outro traumatismo severo. Nessas 
condições, não raro, a mulher como mãe não consegue sequer advir ou, se já havia iniciado esta invenção, entra em colapso e deixa de reconhecer-se naquele filho que, até então, era objeto de identificação. Segundo Kupfer (2001, p. 49-51), o psicanalista sabe, por exemplo, que uma criança com distúrbios neurológicos (natos ou adquiridos), encontrará sérias dificuldades para encontrar uma mãe que "pilote" o corpo do filho, até que este se torne um equipamento mais ou menos operante, uma vez que somente o encontro e o reconhecimento mútuos da mãe-bebê abrem essa possibilidade.

Mais que isso, esse equipamento sequer existirá se não houver quem o construa. Assim, poderemos estar diante de um equipamento defeituoso, que uma mãe poderá "saber" pilotar, enquanto outras ali sucumbiriam. Poderemos estar diante de um equipamento completamente inoperante e uma mãe não poderá humanizá-lo de jeito nenhum, em que pesem seus esforços. Falhou a função materna, não porque a mãe não tivesse condições de exercê-la, mas porque seu bebê não podia absorvê-la (KUPFER, 2001, p. 50).

Mas também podemos estar diante de um aparelho com todas suas funções operáveis, ou seja, "normais" e o bebê, ao nascer, desencaixar do ideal sonhado pela mãe, ou senão, fazer acordar seus fantasmas do infantil - esse outro recalcado, avesso, também um dia esperado pelos pais da mãe, mas que esta também não pôde ser, e recalcou, retornando e sendo reconhecido agora por ela, imaginariamente, na criança que gerou, e que não terá como, a partir daí, se encaixar na imagem especular criada por aquela própria mulher, sua genitora, esta que funcionará como uma espécie de mulher-não-mãe, deixando o corpo do pequeno ser à deriva, já que não o investe (mais) de valor fálico. Nesse caso, não é raro ocorrer aquilo que alguns teóricos chamam, segundo Kupfer, de falhas na especularização, de onde surgem traços autistas associados, muitas vezes, a outras patologias.

O melhor exemplo disso é o surgimento de traços autistas na síndrome de Down. (...) Para as mãe das crianças Down, é muito difícil reconhecê-las como filhos. Mais que isso, não podem reconhecer-se neles. Não podem sublinhar neles um traço imaginário que prezam ou de alguém com quem se identificam. Isto impede o reconhecimento recíproco e a consequente inscrição em uma filiação (Idem, ibidem, p. 50).

Nesse sentido, é por onde avança Lajonquière, quando escreve sobre as formas de recepção de uma criança no seio familiar:

A chegada do recém-nascido ao mundo adulto feito familiar é revestida de inquietante estrangeiridade uma vez que anima o retorno inesperado da condição infantil, supostamente ultrapassada pelos adultos de plantão. A criança pode ser acolhida como testemunho da castração do mundo adulto da castração do Outro - e, assim, abrir a possibilidade de se instalar um 
processo de familiarização do recém-chegado. Porém, o nascimento deste, entretanto, na contramão da familiaridade, pode dar lugar às figuras disjuntas da extraterritorialidade e selvageria. Nestas, o caráter inquietante da estrangeiridade infantil acaba se deslizando até virar uma estranheza de impossível reconhecimento ou metáfora (LAJONQUIĖRE, 2010, p. 205206).

Ou seja, um bebê, antes mesmo de chegar ao mundo, já tem para si um lugar na estrutura do dispositivo discursivo familiar. Entretanto, para ser tomado ali, pela mãe, deverá alienar-se nesse lugar desejado e configurado - por ela - para um objeto: ele, o bebê-falo. Às vezes, isso se mostra impossível, outras vezes não. Por isso, aos que entendem o funcionamento mãe-bebê como uma relação simbiótica, harmônica e fusional, Marie Claude Fourment-Aptekman faz a seguinte observação:

Se Freud é o criador da hipótese da indistinção fusional mãe-filho no início da vida, Lacan a retoma dando-lhe uma outra dimensão: esta indistinção não é um vínculo dual de tipo simbiótico, mas obedeceria mais a uma lógica da carência. Segundo Lacan, para o bebê, alguma coisa falta, há um lugar de vazio, e a criança preenche esse vazio identificando-se imaginariamente com o objeto que se supõe faltar à mãe, isto é o falo (FOURMENT-APTEKMAN, in BERNARDINO, 2006, p. 115).

Para ilustrar a citação que acabamos de fazer, utilizaremos uma escultura de Caetano Fraccaroli esculpida em enorme e único bloco de mármore branco, intitulada "Mãe", com a qual venceu, em 1964, um concurso nacional sobre o tema, promovido pelo Diários e Emissoras Associados, de Assis Chateaubriand, que pode ser vista na Praça Buenos Aires, em Higienópolis, São Paulo, dentre um conjunto de outras esculturas espalhadas pelos jardins. Embora acostumados a visitar com certa regularidade o local - muito utilizado para que crianças pequenas tomem sol e brinquem aos pés do altar, digo, aos pés da "Mãe" - , dos bancos dispostos em círculo ao redor da imensa figura, nunca até então havíamos prestado atenção no detalhe que pudemos, finalmente, sintetizar e fazer precipitar em uma série de desdobramentos durante o período final deste escrito.

A“Mãe" fica no ponto mais alto da praça, escondida uma clareira rodeada por árvores, disposta como se fosse um obelisco, o que teria contrariado a vontade do próprio escultor que a queria num local em declive, em meio a um gramado (c.f. MALERONKA, 2000, p.47). Para que os visitantes cheguem até ela, é preciso subir as alamedas ensombreadas até o grande círculo, onde a escultura resplandece, feito imagem religiosa a céu aberto. Instalada dessa maneira, de tão impactante, parece cumprir não a função de uma obra de arte, mas a função de um monumento. 


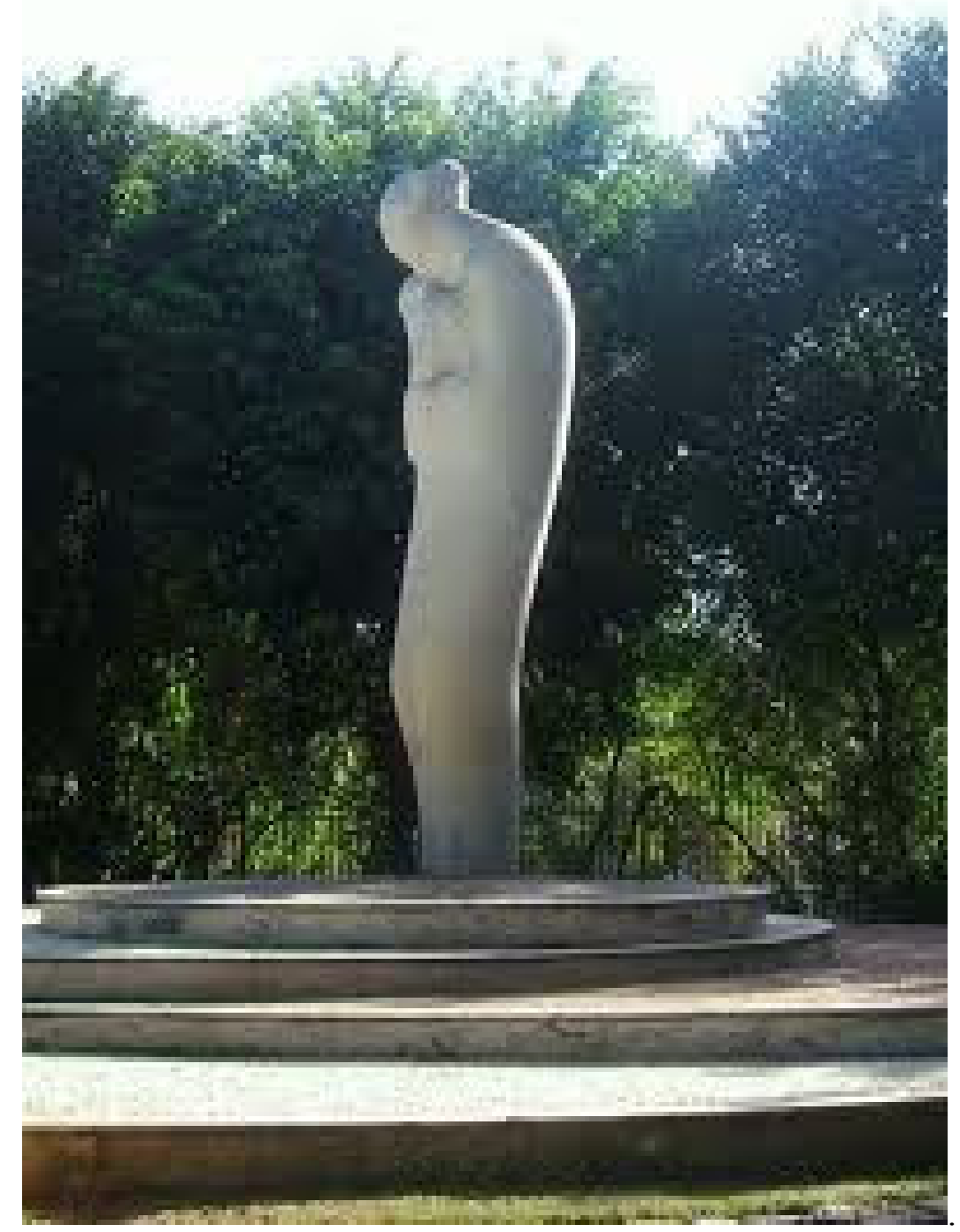

Figura 5.1 - 1 "Mãe", escultura em mármore, de Caetano Fraccaroli

Não podendo ser vista de longe, nem de de nehum dos portões que dão acesso à praça, o visitante de primeira viagem que se depara, sem esperar, com tão grande e resplandecente objeto, não tem como evitar um efeito de suspensão.

Observando-a de frente, podemos distinguir uma figura estilizada de mulher, em cujos braços está um bebê ao colo, tendo parte de seu rosto "colado" ao dele. Observando-a em giro, entretanto, novos contornos vão aparecendo, como vemos na sequência de imagens da Figura 5.1-2, até que se fique de frente para as costas da mulher, fazendo-se "ver", então, o que bem podemos interpretar como sendo um enorme falo. 

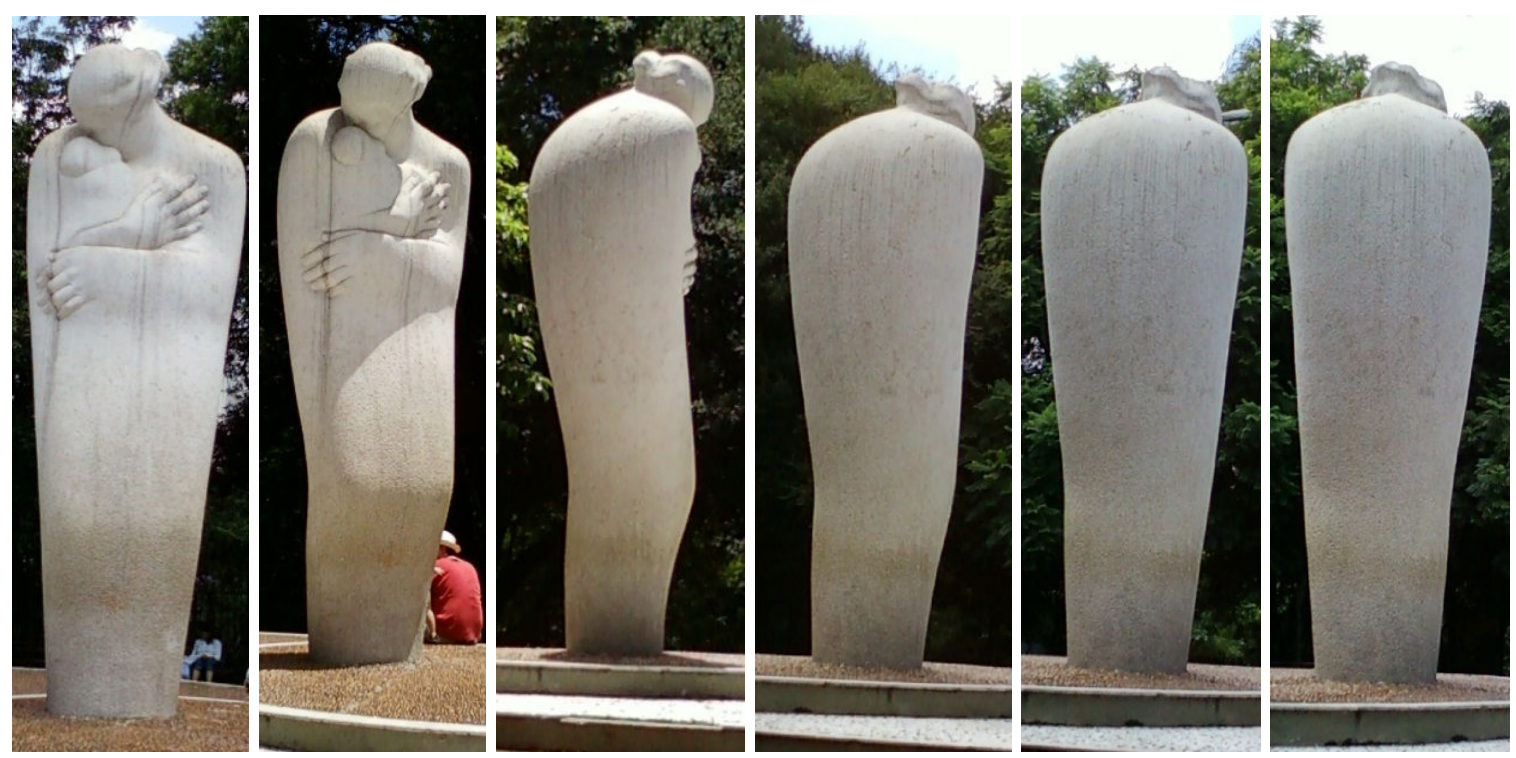

Figura 5.1-2 Na sequência de fotos em giro de $180^{\circ}$, a escultura"Mãe" vista por trás

Depois de verificarmos a possibilidade deste "avesso fálico", de fato começamos a inflectir sobre outros elementos da escultura, em novas perspectivas, como por exemplo: 1) o corpo do filho parece emergir do corpo da mãe, como se estivesse, ainda em parte, fundido a ela, embora já não todo, como se estivesse sendo puxado para fora, via olhar, beijos, manhês, cheirar, para "nascer" mais uma vez, não do ventre, mas de um brotar, de um diferenciar-se a partir do próprio corpo dela, na espera de, algum tempo depois, ter o corpo delineado, finalmente separado e destinto. Neste que é um deslizamento de sentidos, como ocorre quando estamos na categoria da terceiridade ${ }^{156}$, descrita por Pierce, bem poderíamos dizer que

\footnotetext{
156 Através da análise do modo como as coisas aparecem à consciência, considerando como experiência de pensamento tudo aquilo que se impõe ao reconhecimento humano, por volta de 1867, a partir do estudo da lógica, Charles Sanders Peirce postulou que tudo o que aparece à mente obedece a uma gradação de categorias universais de pensamento: qualidade, relação/reação e representação/mediação, denominadas por ele com uma terminologia específica aos seus estudos, sendo elas as categorias de primeiridade, secundidade e terceiridade. Peirce reduzia a essas três categorias a multiplicidade e a diversidade encontradas nos fenômenos, inclusive os da natureza. (...) Podemos dizer que a categoria de primeiridade corresponde apenas a uma parte do fenômeno, sua qualidade no instante presente em que ele acontece, sua possibilidade de ser. Primeiridade tem a ver com o acaso, com o que é original, livre, espontâneo, novo, precedente de toda síntese e diferenciação. Pura qualidade de ser das coisas. Nela, o fenômeno é presente e imediato, sem representações. A impressão primeira é indivisível, não analisada, por isso inocente, já que não foi ainda pensada, tampouco falada - quando isto ocorrer, já teremos saído da primeiridade, em si aquilo que passa por nossa mente em um átimo de segundo antes de criarmos qualquer tipo de pensamento subjetivo a seu respeito, como qualidades existentes no mundo que aparecem ou são percebidas/sentidas antes de passarem pela articulação de nossos pensamentos inevitáveis, todavia. (...) A categoria de primeiridade indica essa forma rudimentar, vaga, imprecisa e indeterminada de se perceber as coisas, pois quando nos pusermos a falar delas, já estaremos selecionando e construindo representações, entrando nos níveis de secundidade e terceiridade. Quando o sentimento ou a impressão ainda está indivisível, e não foi dita ou pensada, está em primeiridade, porém quando essa sensação produz seu efeito em nós, provocando reações, conflitos, ainda que anteriores à mediação do pensamento articulado, então estamos no campo do que é segundo, da secundidade, pois as reações são subsequentes à pura percepção, que é primeiridade. Na secundidade, encontramos aquilo que é provocador, mote de pensamentos subsequentes. Reação sem pensamento deliberado, pois quando adentrarmos aí, já estaremos em terceiridade. (...) A terceiridade, como já foi citado anteriormente, corresponde ao processo de mediação interpretativa das
} 
aqui o educto se apresenta, fazendo sair, "puxando" para fora esse projeto de corpo e sujeito e como dizia Kupfer, fazendo borda, fazendo limite -, senão pelo beijo, pelo olhar, o cheirar, o manhar que fez entrar, pelo educatio, a palavra que recorta, o estilete, o estilo daquela mãe; 2) outro detalhe a causar estranheza: o tamanho avantajado das mãos e concomitante detalhamento dos dedos, já que nenhuma parte da mulher ou da criança foi tão naturalmente esculpida, sendo o resto do conjunto muito mais "estilizado". Por que o artista teria feito assim? Haveria nessas mãos, talvez, a intenção de simbolizar e valorizar os cuidados da maternagem? Ou, para além dela, a sensualidade do toque que erogeniza o corpo polimorfo do bebê pelos cuidados primordiais? ; 3) seja também em relação aos atributos de feminilidade daquela mulher, como no detalhe do penteado, dos cabelos dela, que ou estão curtos, porque estão cortados, ou porque foram presos, combinando com o corpo sem cintura, em postura curvada por sobre o filho, aludindo às trasnformações da mulher que se toma nesse momento mais como "mãe", do que propriamente como mulher que se enfeita em atributos de feminilidade para um homem?; 4) o encontro dos rostos, por sua vez, que seria? Dependendo do ângulo de observação, também sugere mais do que uma interpretação: mãe-cheira-filho, mãe-beija-têmpora-do-filho, ou filho-e-mãe-se-beijam? Não esqueçamos de que o artista gostaria que tivéssemos acesso, também, aos ângulos de cima para baixo para a visão das cabeças da mãe e do filho, o que é pouco provável devido à forma como a mesma foi instalada nesta praça, só permitindo a observação na perspectiva de baixo para cima. De qualquer modo, conseguimos uma única imagem da escultura captada de cima para baixo, quando esta não se encontrava no local atual de instalação, e que disponibilizamos à esquerda da sequência a seguir, na Figura 5.1-3.

experiências vividas ou dos fenômenos observados por nós. Estar na terceiridade é fazer a síntese intelectual, a elaboração cognitiva que aproxima primeiridade e secundidade em representações e interpretações. A ideia mais simples de terceiridade, segundo Pierce, é a de signo (ou representação). De acordo com Lucia Santaella, "Diante de qualquer fenômeno, isto é, para conhecer e compreender qualquer coisa, a consciência produz um signo, ou seja, um pensamento como mediação irrecusável entre nós e os fenômenos. (...) o simples ato de olhar já está carregado de interpretação, visto que é sempre o resultado de uma elaboração cognitiva, fruto de uma mediação sígnica que possibilita nossa orientação no espaço por um reconhecimento e assentimento diante das coisas que só o signo permite. Em síntese: compreender, interpretar é traduzir um pensamento em outro pensamento num movimento ininterrupto, pois só podemos pensar um pensamento em outro pensamento. É porque o signo está numa relação a três termos que sua ação pode ser bilateral: de um lado, representa o que está fora dele, seu objeto, e de outro lado, dirige-se para alguém em cuja mente se processará sua remessa para um outro signo ou pensamento, onde seu sentido se traduz. E esse sentido, para ser interpretado, tem de ser traduzido em outro signo e, assim, ad infinitum" (SANTAELLA, 1983, p. 51 e 52). 

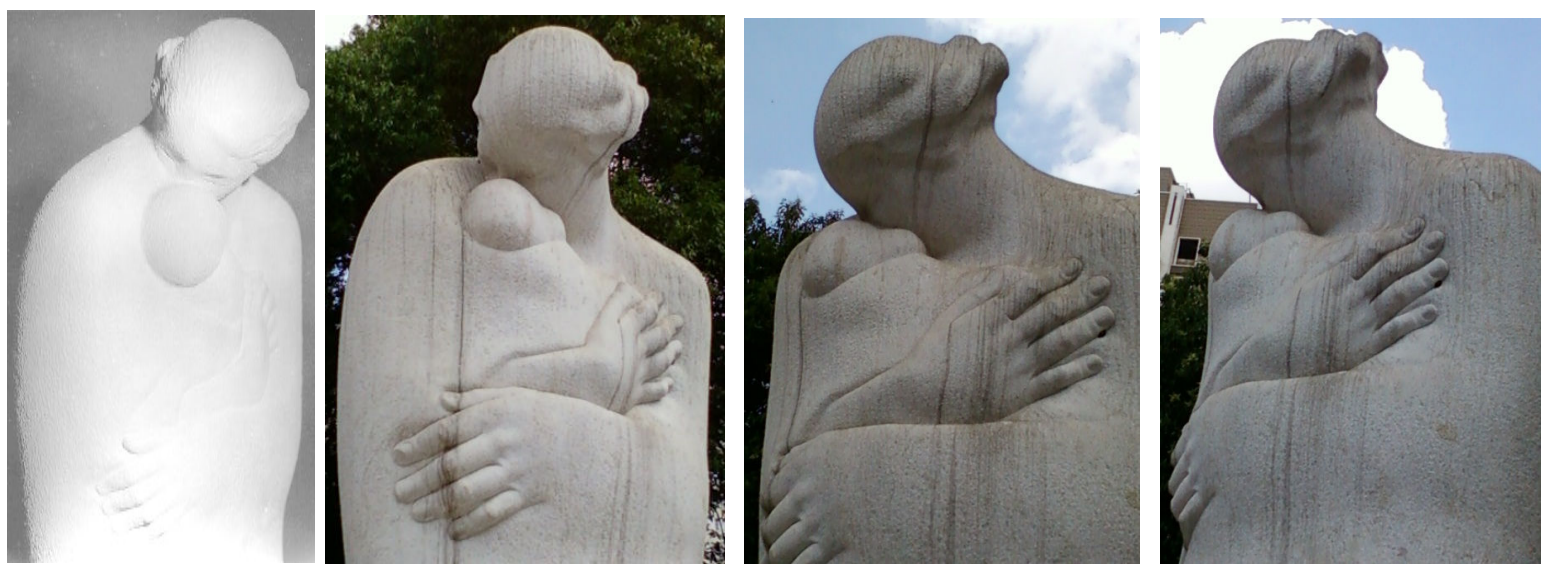

Figura 5.1-3 Parte superior da escultura "Mãe", em ângulos diferentes

Enfim, que mãe é essa, fálica, que nos interroga, a partir do Outro, quando tentávamos definir a função do educador? É a mãe-toda? Certamente não, porque nos parece que já anuncia um desprendimento do filho, motivo pelo qual acabamos desistindo de manter o desejo-da-mãe num dos extremos do pendular da função do educador, "Mãe, é uma só" e educador algum poderia reeditar sua função, o que nos fez declinar para desejo-de-pedagogo por conta de uma estrutura educativa não-familiar e também daquilo que Maud Mannoni apontava como furor pedagógico, , que tal qual o desejo-da-mãe, acaba sendo, também, desejo de devoração, porque reedita um desejo sem limite de saber e fazer sobre o outro, feito atuação de pedagogo obssessivo e ortodoxo funcionando como uma grande boca de crocodilo, como viu-se em Itard, "legitimada" não mais em nome da maternidade, mas pelo discurso universitário, discurso tecnocientificista. A diferença estaria no objeto do desejo, um sendo o filho, do qual a mãe tudo sabe, e o outro o educando, de quem tudo se fala, porque dele também tudo se sabe, com a "legitimidade" aferida pelos diagnósticos, em geral, nãodiferenciais, o que não deixa de configurar uma outra obscenidade - diagnóstica, digamos.

A propósito, sobre o desejo da mãe, Lacan afirma:

Cada vez mais, os psicanalistas embarcam em algo que é, de fato, extremamente importante, a saber, o papel da mãe. Essas coisas, meu Deus, já comecei a abordá-las.

O papel da mãe é o desejo da mãe. É capital. O desejo da mãe não é algo que possa se suportar assim, que lhes seja indiferente. Carreia sempre estragos. Um grande crocodilo em cuja boca vocês estão - a mãe é isso. Não se sabe o que lhe pode dar na telha, de estalo fechar sua bocarra. O desejo da mãe é isso.

Então tentei explicar que havia algo de tranquilizador. Digo-lhes coisas simples, estou improvisando, devo dizer. Há um rolo, de pedra, é claro, que lá está em potência, no nível de borracha, e isso retém, isso emperra. É o que se chama falo. É o rolo que os põe a salvo se, de repente, aquilo se fecha (LACAN, 1998, p. 118). 
- Não há como negar, Lacan tinha um senso de humor bastante refinado. Qual teria sido a prosódia ao enunciar em alto e bom som, que na boca da mãe, enquanto mulher, ele coloca, nada menos que ... um rolo, de pedra, é claro, que lá está em potência... o que é um jeito muito elegante de dizer a coisa, seu estilo, porque poderia ter usado a linguagem chula, o que talvez não se permitisse diante de um auditório, na posição de um professor e acadêmico.

Sobre os estilos de Lacan, Gilbert Diatkine dirá:

Muitos de seus textos, de estilo clássico, são de leitura fácil, sem serem perfeitamente claros. Outras passagens são escritas com uma veia francamente humorística. Lacan cita Alphonse Allais, Préver, Jarry, Courteline. No meio de uma difícil demonstração ou de uma polêmica apaixonada, desconcentra sua plateia, demonstrando, como uma brincadeira, que não está falando sério. Gosta de mistificar - o nome seminário XXI é intitulado "Les non-dupes errent" se afirmado, toda sua obra como pura mistificação. Emprega todos os tipos de comédia: o humor, o dito espirituoso, que se transfomra em uma técnica interpretativa e em um meio de pesquisa, e sobretudo a ironia, que às vezes se transforma em sarcasmo ou até mesmo insulto. Lacan, de fato, possui uma particularidade singular em uma disciplina na qual as polêmicas sempre foram violentas, de insultar, às vezes de forma grosseira, seus adversários. Muitas vezes, o sarcasmo substitui o argumento científico (DIATKINE, 1999, p. 14).

Mas sigamos um pouco mais, porque parece importante, já que para o desejo-da-mãe está o desejo-do-filho, como vimos na questão do recalque incompleto, quando o infantil insiste em nada querer saber da castração, enquanto nos perguntamos, também pela metonímia e metáfora, em função de quê estará o desejo-do-pedagogo... Talvez para o desejo-do-cafécomleite no campo educativo, ou seja, aquele educando que tal qual criancinha muito pequena, está ali, misturados aos demais, mas bem poderia não estar, porque a mínima diferença faz, já que as crianças maiores acordam entre si sua presença e a permitem, mas só no faz-de-conta, porque na realidade essa criancinha fica apartada da brincadeira dos “maiores”, podendo, então, fazer qualquer coisa, uma vez que nada ou tudo que fizer valerá o mesmo, o que para as crianças que já percebem esse jogo dentro do jogo - na verdade um engodo - tomam-no como um insulto, motivo de suas reivindicações para que possam participar, de verdade, da brincadeira, valendo-se mais do que nada:

O complexo de Édipo, tal como nos é contado por Freud quando se refere a Sófocles, não é em absoluto tratado como um mito. É a historieta de Sófocles sem, como veremos, o trágico. Segundo Freud, o que revelou a peça de Sófocles é que se dorme com a mãe quando se matou o pai - assassinato do

\footnotetext{
${ }^{157}$ Dupe, em francês, pode ser traduzido por "pato", "tolo", de modo a fazer o soar "Les Noms du père" como "Les non-dupes errent", algo do tipo "os não-tolos/patos erram".
} 
pai e gozo da mãe, a ser entendido nos sentidos objetivo e subjetivo. A gente goza com a mãe e a mãe goza. Que Édipo não saiba absolutamente que matou o pai, nem tampouco que faça sua mãe gozar, ou que goze com ela, nada disso muda a questão posto que é, justamente, um belo exemplo de inconsciente (LACAN, 1998, p. 119-120).

Então, voltemos ao que a psicanálise de crianças vem dizendo a respeito desse que pode ser um momento da função materna, mas não todos, quando chama a atenção e faz notar que a criança, dentro da estrutura, também irá ocupar um lugar de valor funcional, impossível de saber de antemão, a não ser a posteriori, a respeito de como a criança vai se engajar, se introduzir e se substituir ao apetite materno pelo falo faltoso, no registro que cumprirá, portanto, a função simbólica de filho, pois de duas, uma: ou posicionar-se-á no lugar de ocupar a metáfora do amor da mãe pelo pai, ou funcionará como a metonímia do desejo materno pelo falo, de onde se extrai as seguintes consequências:

No texto "Duas notas sobre a criança", Lacan (1969) afirma que a criança pode ocupar o lugar de sintoma do casal parental ou pode realizar a presença do objeto $a$ no fantasma materno. No primeiro caso, houve a articulação do par conjugal, com a presença de uma mãe, que, pela via de suas próprias faltas, abriu um lugar para a mediação paterna, para a presença de um pai que pode vetorizar a transmissão de um desejo, que não seja anônimo.

No segundo caso, a função do pai não operou e não houve substituição metafórica, e a criança, como correlato do fantasma da mãe, vem saturar o "modo de falta em que se especifica o desejo (da mãe), qualquer que seja sua estrutura especial: neurótica, perversa ou psicótica" (LACAN, 1969, p. 5) (FARIAS ; LIMA, 2004, p. 22)

Em seguida, as autoras explicam que, ao saturar o modo de falta da mãe, a criança dálhe corpo por meio de um traço particular, ou de seu próprio corpo, ofertando-se como objeto que condensa o gozo da mãe, condensando sobre seu ser a verdade do objeto materno. Ao nascer, “(...) a criança surge para a mãe no real, como objeto de sua existência. O que pode ser articulado com o que Lacan nomeia real, irredutível, irrepresentável na relação entre a mãe e a criança" (Idem, ibidem, p. 23). No entanto,

Entre a mãe e a mulher existe um hiato, aliás muito sensível na experiência. Às vezes, o fillho fálico é passível de tamponar, de silenciar a exigência feminina, como vemos nos casos em que essa maternidade modifica radicalmente a posição erótica da mãe. No essencial, porém, o dom do filho só raramente permite fechar a questão do desejo. O filho, como resto da relação sexual, realmente pode obturar em parte a falta fálica da mulher, mas não é a causa do desejo feminino que está em jogo no corpo a corpo sexual (SOLLER, 2006, p. 35).

Daí a diferenciação feita pela autora entre o desejo-da-mãe e o amor materno, atentando que o primeiro deve ser entendido como desejo sexuado, ou em outras palavras, 
desejo de mulher (Idem, ibidem, p. 99). E o que arrefece esse desejo de mulher, isso que Soller formula magistralmente como sendo o desejo de gozar o quanto deseja (cf. Idem, ibidem, p.36)?

O ser mãe resolve essa falta [fálica] através do ter, sob a forma do filho, substituto do objeto fálico que lhe falta. No entanto, o ser mulher da mãe não se resolve inteiramente no ter fálico substitutivo (...). Justamente na medida em que seu desejo diverge para o homem, é mais a ser ou a receber esse falo que a mulher aspira: a sê-lo, através do amor que faliciza, e a recebê-lo, por intermédio do órgão com que ela goza, mas nos dois casos, ao preço de não o ter (cf. Idem, ibidem, p.100, acréscimo nosso).

Assim, a configuração da relação estruturada entre o homem e mulher dentro de uma família irá determinar o lugar da criança na estrutura, e para que tudo saia mais ou menos a contento na constituição psíquica da criança, a relação especular mãe-fillho, inexoravelmente, deverá sofrer uma intervenção, um corte simbólico

(...) já que toda e qualquer relação a dois está sempre mais ou menos marcada pelo estilo do imaginário; e que para que uma relação tome seu valor simbólico, é preciso que haja a mediação de uma terceira personagem que realize, em relação ao sujeito, o elemento graças a que sua relação ao objeto pode ser mantida a uma certa distância (LACAN, 1953).

Para tanto, o pai deverá estar, segundo Lacan (1974-5), père-versamente orientado de modo a fazer de uma mulher o objeto $a$, que cause o seu desejo. Assim, essa père-version indica uma versão, uma orientação, rumo ao pai (cf. FARIAS ; LIMA, 2004, p 23) - pèreversion que substituirá a perversão na mulher de ter filhos, segundo Sauret (1997), o que permite haver uma subtração de gozo da mulher, possível de ser transmitido à criança.

Entre a relação imaginária e a relação simbólica, há toda a distância que há na culpabilidade. É por isso, a experiência mostra, que a culpabilidade sempre tem a preferência sobre a angústia. A angústia está, em si mesma, desde logo, isso sabemos através dos progressos da doutrina e da teoria de Freud, ela está sempre ligada a uma perda, isto é, a uma transformação do eu (moi), isto é, a uma relação a dois prestes a esvanecer e à qual deva suceder algo que o sujeito não pode abordar sem uma certa vertigem. Isso é que é a natureza e o registro da angústia. Assim que o terceiro se introduz, que entra na relação narcísica, introduz a possibilidade de uma mediação no real pelo intermédio essencialmente da personagem que, em relação ao sujeito, representa uma personagem transcendente, em outras palavras, uma imagem de mestria, por meio da qual seu desejo e cumprimento podem se realizar simbolicamente. (...) O sujeito está completa e especialmente exposto, (...) a esta espécie de vertigem que surge, e sente a necessidade de afastá-la [portanto de recalcála], de fazer alguma coisa transcendente (LACAN, 1953, acréscimo e negrito nossos) 
Quando indagado por alguém do auditório sobre o que seria esse "transcendente", eis a resposta dada por Lacan:

É isto: que na relação com seu semelhante, como tal, na relação a dois, na relação narcísica, sempre há, para o sujeito, algo desvanecido. Ele sente, afinal de contas, que é o outro e que o outro é ele. E este sujeito definido reciprocamente é um dos tempos essenciais da constituição do sujeito humano. É um tempo em que ele não quer subsistir, ainda que sua estrutura esteja sempre no ponto de aparecer, e muito em certas estruturas neuróticas. A imagem especular se aplica ao máximo. O sujeito não é senão o reflexo de si mesmo. A necessidade de constituir um ponto que constitua o que é transcendente é justamente o outro enquanto outro (Idem, ibidem).

E para completar, o que é absolutamente incrível termos achado, como se andássemos num brejo, a la Manoel de Barros, e déssemos no sapo sem ter procurado, eis o que recebemos de forma invertida do Outro em Lacan, quando tenta explicar que o totemismo é o modo de relação humana mais primitivo do homem absorver da substância do seu semelhante, sem precisar devorá-lo, como no canibalismo:

Aí vocês veem bem qual é a função do totemismo. É de fazer dele um sujeito transcendente àquele. (...) Aí encontramos várias questões sobre um dos pontos que mais nos interessam: a relação entre crianças e adultos. Os adultos, para a criança, são transcedentais na medida em que eles são iniciados. O mais estranho é que as crianças não são menos transcedentais para os adultos. Isto é, por um sistema de reflexão característico de toda e qualquer relação, a criança se torna, para os adultos, a causa de todos os mistérios. É a sede desta espécie de confusão das línguas entre crianças e adultos, e um dos pontos mais essenciais que devemos levar em conta, quando se trata de intervenção sobre as crianças (Idem, ibidem).

$*_{-} *_{-} *$

Kamers (2005) assinala desde o início de seu trabalho, que é possível perceber na psicanálise uma espécie de privilégio dado à função paterna em detrimento da função materna em relação ao processo constitutivo do sujeito, como se a função paterna cumprisse uma função de pivô (cf. MENA, 2004, p. 3) da constituição subjetiva da criança, de modo a relegar a função materna ao segundo plano, sendo recorrente ouvir, inclusive, que "qualquer um" pode vir a encarnar o lugar da mãe - o que no seu entender é um engano, e no nosso também, o que precisa ser explicado.

Pela lógica do nosso protomodelo, seria como admitir, por equivalência, que “qualquer um" pode ocupar o lugar do educador, ou mesmo de pai, o que de maneira alguma 
costuma acontecer. Porque de alguma forma, o endereçamento pendular de um educador, assim como a palavra de uma mãe, de um pai, deve ter um peso, um lastro estrutural, como visto anteriormente, o que no caso do educador se configura pela intimidade que demonstra ter com a cultura, ou em outras palavras, com o laço que faz com ela e que transparece no estilo de seus enunciados e enunciações, lastro singular - queremos crer - que dará maior ou menor poder de impregnação à sua palavra de mestre, pelo refinamento adquirido (ou não) enquanto sujeito que representa a cultura para os não iniciados, educador que, ao inventar-se, cuidou de si mesmo e acabou construindo, em seu percurso de vida, aquele estranho objeto brilhante e difuso chamado agalma ${ }^{158}$ que a nós, parece o selo de um estilo. Por esse motivo, as considerações de Kamers a respeito da função materna reverberam naquilo que entendemos ser a função de educador, no sentido de um valor que estará ou não em condições de ocupar esse lugar de identificação, de ágalma, como se dá com Alcibíades em relação a Sócrates, quem, definitivamente, não há de ter sido uma pessoa "comum".

Nesse ponto, um tanto provocativo, perguntamos, até que ponto uma pessoa tão “comum" assim, no sentido de sujeito que não guarde nada dentro de si que remeta à preciosidade enigmática de um ágalma, ainda que insurgente, pode encampar a palavra impregnante de um educador?

- O problema é saber como este tesouro vai parar ali dentro..., ou melhor, o que é possivel ser feito, na formação de um educador, para que ele teça esse objeto valioso de

\footnotetext{
${ }^{158}$ Ágalma ou agalma: Brilho fálico do objeto $a$, em que o desejável se define, não como fim, mas como causa do desejo. A palavra "ágalma" oriunda da poesia épica grega, tornou-se um dos conceitos mais fecundos da teorização lacaniana do desejo de transferência. Esse termo foi destacado por Louis Genet, em seu artigo " $L a$ notion mytique de la valeur em Grèce" (Journal de Psychologie, out.-dez. 1948). Ele designa um certo número de objetos mobiliários preciosos e brilhantes. Ágalma vem de agallein, "enfeitar", e "honrar", e de aglaé, "a brilhante". Em tal projeto de arqueologia da noção de valor, Louis Genet mostra como os agalmata são objetos de troca e de transmissão (...) Sua origem, sempre misteriosa - surgimento do mar, encontro e prodígio, núpcias divinas -, faz deles as insígnias do poder, mas também de sua perda sempre possível. (...) Nos primórdios da época mercantil, o objeto precioso, representação e signo do valor, indica a origem da moeda, na medida em que ela escapa à pura racionalidade das trocas e das transmissões calculáveis. O ágalma é, pois, de saída, o que vale na e pela troca, próprio a situar o desejável em sua natureza de comércio e de linguagem. Lacan em seu seminário de 1960-1961, Le transfert dans sa disparité subjective, sa prétendue situations, ses excursions techniques, introduz a noção de ágalma a propósito do amor de transferência: qual a relação do sujeito do inconsciente com o objeto de seu desejo? (Christiane Lacôte, in: CHEMAMA ; VANDERMERSCH, 2007, p. 26); O que seduz Alcibíades em Sócrates é seu ágalma; Alcibíades compara Sócrates com a estatueta grotesca de Sileno; Lacan observa que, nessa época, objetos desse gênero eram também receptáculos, caixas de joias; o ágalma é, portanto, não apenas objeto precioso, mas também objeto escondido "no interior"; enfim, como objeto de oferenda, ele é aquilo com que se pode captar, seduzir a atenção divina. Em sua lição 10 do Seminário 8: a transferência, Lacan disse isto: "Se esse objeto os apaixona, é porque lá dentro, escondido nele, está o objeto do desejo, ágalma (o peso, a coisa pela qual é interessante saber onde está esse famoso objeto, saber sua função e saber onde ele opera, tanto na inter - como na intra-subjetividade), e na medida em que esse objeto privilegiado do desejo é alguma coisa que, para cada um, culmina nessa fronteira, nesse ponto limite que lhes ensinei a considerar como a metonímia do discurso inconsciente, onde ele desempenha um papel que procura formalizar [...] na fantasia (Christiane Lacôte, in: KAUFMANN, 1996, p. 16, grifo nosso).
} 
troca. Porque a nós, com certeza, não parece que seja pelos meios ortodoxos da psicometodologia de ensino, ou regulamentadas e forçadas formações continuadas.

Com isso não estamos dizendo que qualquer mortal não possa se tornar, ou ocupar o lugar de um educador, inventando-se como tal - porque assim fazem também qualquer homem disposto a encarnar a figura de um pai e, por sua vez, também qualquer mulher que deseje saber-se como uma mãe - nesse sentido, sim, qualquer um pode tentar inventar-se nessa função, embora nem todos consigam ou se mostrem inclinados a se implicarem nesta construção, ou melhor, perlaboração de si.

Mas voltemos à susposta primazia da função paterna, que antes da digressão "agalmica", era a nossa intenção de percurso:

Nos textos lacanianos e nos meios analíticos, é de conhecimento geral o valor dado à função paterna no interior da teoria, tanto que alguns autores lacanianos vão afirmar que a única função é a paterna. Do mesmo modo, não é raro escutarmos por aí que Lacan não falava em função materna, mas em desejo materno. Entretanto, a primeira questão suscitada é de quais fontes Lacan se utiliza para formular o conceito de função? Esta questão é fundamental, já que podemos falar em função no sentido funcionalista, ou desde o paradigma estruturalista. E poderíamos ainda indagar: não parece óbvio que Lacan fala de função no sentido estruturalista? Pensamos que não, já que no texto de 1938 sobre os complexos [familiares] Lacan já fala em função, sendo que o recurso ao estruturalismo somente se deu em 1953 (KAMERS, 2005, p. 16, acréscimo nosso).

O que incomoda a autora, e também a nós, é que essa cisão realizada na teoria lacaniana acaba por atribuir

(...) uma espécie de valor absoluto à função paterna, geralmente associada com a figura do pai real, portanto transmissor da lei, enquanto sobre as mulheres, frequentemente pensadas como agentes da função materna, recai o imaginário relativo a uma espécie de natureza feminina. (...) Esta cisão, ou crença compartilhada vai culminar numa série de preceitos acerca das funções parentais, especialmente o algoritmo de que à função paterna caberia a palavra e a lei, enquanto à função materna caberia a vida sensorial com a criança (Idem, ibidem, p. 16).

Se fosse assim, nosso protomodelo pendular não procederia e teríamos que admitir que a função do educador seria reeditar só a função paterna, ou a função dos Nome(s)-do-Pai, como tentaremos mostrar logo mais, o que não é possível por conta do que retorna das reminiscências de educadora. Aliás, é preciso pedir licença para mais um importante aparte, já que o laboratório de nossas incursões pela psicanálise $n a$ educação vem ocorrendo há muito tempo, sem o fomento das agências de pesquisa, nem sob os seus prazos, e custos, mas em 
nome-próprio, nisto que não funciona como uma instituição, mas que encontra sua viabilidade na parceria com escolas que se propõem um trabalho de qualidade.

A hipótese do desejo materno no pendular do educador começou a nos acenar, por exemplo, por volta de 2001, quando dávamos - eujemoi - aulas para um garoto de 12 anos, que sinalizava dirigir-se para a segunda reprovação do $6^{\circ}$. ano do Ensino Fundamental, por conta de dificuldades generalizadas no aprender escolar, especialmente aqueles relativos à matemática e à compreensão de texto, apesar de já ser um leitor costumaz em duas línguas (português e espanhol). Entretanto, como não somos atados ao furor diagnóstico, isso que poderia ser devorado pelo desejo-de-pedagogo na bandeja da discalculia, do déficit de atenção, da dislexia, da baixa inteligência, entre outros, simplesmente não nos atraiu, embora o garoto pudesse ser tomado como um prato cheio dessas iguarias tecnocientíficas. Contudo, ao começar a intervenção de nossas orientações de estudo, algo nele permanecia fechado e minha palavra não parecia entrar. Tentava de todas as formas, mas o educatio não funcionava. Foi então que, sem sabermos como nem porquê, nos ocorreu, pela primeira vez, levar-lhe algo para comer, visto que a pessoa que cuidava de sua alimentação oferecia sempre os mesmos alimentos, pouco ricos em vitaminas, cores e sabores, o que chamou nossa atenção, porque sua mãe não trabalhava fora, estava sempre em casa, mas fechada em seu quarto, envolta na leitura de livros "espíritas", como contou-nos certa vez, mostrando-se pouco interessada no que o filho, em fase de crescimento acelerado (o pai era altíssimo e ela também), comia ou deixava de comer.

\section{- Eujemoi não suportava isso!}

Banana, maçã, laranja, melancia, mexerica, paçoca, tahine com mel, pão integral, pamonha, bolo que era feito em casa para nossos filhos, pastel, bolinho de arroz integral, coisas desse tipo eujemoi, um pouco antes de sair de casa, recolhia do dia-a-dia doméstico para levar a ele. No começo, achou engraçado, ou melhor, achávamos, estranhando aquela iniciativa de ares "pouco pedagógicos". Tentava explicar-lhe, para além dos conteúdos escolares - embora "transversais" - , a importância do cuidado com a própria alimentação (que hoje sei, faz parte do cuidado de si mesmo, como mostrou Michel Foucault, em $A$ Hermenêutica do Sujeito), o que ele a princípio ouvia com desconfiança, fazendo graça, afinal não estávamos estudando as vitaminas e o tempo da aula estava passando, "não íamos estudar nada da escola"?! No entanto, foi esse gesto nada ortodoxo, possivelmente histérico, que permitiu, aos poucos, que ele se abrisse enquanto aluno para a nossa intervenção. Com o tempo, ao nos ouvir chegar, vinha correndo, disfarçando a ansiedade pelo que havíamos 
trazido naquele dia, ficando até um pouco sentido quando nada havia para devorar. Sim, às vezes havia nada para devorar, o que com a psicanálise, a posteriori, pudemos também entender a importância de. A anorexia explicou.

Em duas vezes por semana, com aulas de aproximadamente uma hora e meia, junto com as frutas, os quitutes, as bobagens e também sugestões de alimentos "politicamente corretos" que indicávamos para que ele mesmo fosse comprar no supermercado - uma vez que não era a mãe quem fazia as compras, e o pai passava a maioria dos dias fora da cidade , parecia que ia junto, pelo educ(a)tio, as regras de acentuação, os produtos notáveis, o verbo to be, os estados e capitais do Brasil, o capitalismo, o socialismo, enfim, todo o currículo programático escolar.

Conclusão, esse menino nunca mais foi reprovado. Aprendeu a se haver com os números, com a escrita, entrou num curso de inglês - a que se negava, até então - apesar de recusar o encerramento de nosso trabalho até o final do ensino fundamental, sendo nesses 30 anos de profissão o único caso que a orientação permaneceu por quatro anos consecutivos. Recentemente, por esses presentes que os encontros inesperados às vezes nos dão, encontramos o pai dele e pudemos saber que, depois do intercâmbio de um ano na Austrália, em meio ao Ensino Médio - feito inteiro pelas “próprias pernas" -, há pouco menos de um ano havia entrado na faculdade e cursava, com entusiasmo, o curso de psicologia. Conversando com ele, ao telefone, contando um pouco de nossa dissertação e dos estudos na conexão entre psicanálise e educação, fiquei sabendo - para a alegria do meu espelho de pedagoga não ortodoxa - , que sua leitura preferida, nas horas vagas, quando não tinha que se preocupar com os trabalhos acadêmicos, eram mesmo os textos de Freud!

\section{- Ai ai ai ... há anos estou para contar essa história...}

Pois é, esse foi o início do esboço do nosso protomodelo, porque de lá para cá não pudemos não prestar atenção nesse "nutrir" simbólico que cabe também a uma mãe, mas que bem podia, então, ser reeditado por um educador, por um professor, devido a esse que foi , em verdade, um primeiro testemunho. Voltemos.

Portanto, se a mãe, para Lacan, ocupa na estrutura do discurso familiar o lugar de representante primeiro do Outro, esta não deixa de ser, também, uma função simbólica, porque estruturada e estruturante dentro do discurso, de modo que não caberá a "qualquer um" incorporar as condições estruturais discursivas, perante uma criança e inventar-se como mãe (cf. KAMERS, 2005), mesmo porque a função materna e a função paterna não são elementos isolados na estrutura por estabelecerem entre si uma relação de diferenças, de 
oposições, das quais depende a fundação do psiquismo do filho, assim como também, por outro lado, a criança/sujeito que vai surgindo, acaba promovendo, em ambos, efeitos subjetivos, afinal, o homem de antes, será igual ao homem que, depois, pôde (ou não) se inventar como pai, e vice-versa, em relação à mulher, que se inventou e foi inventada (ou não), um dia, como mãe?

Se por um lado, a clínica psicanalítica demonstra que não há sujeito desejante sem que opere dentro da família a função paterna, por outro lado, como vimos, também não há como haver função paterna sem que tenha havido, antes, a encarnação do desejo da mãe, endereçado ao filho, por parte de uma mulher. A mãe do manhês, a propósito, não é outra senão aquela que cumpriu também a função simbólica de lançar seu filho no campo da palavra e da linguagem sem pedir autorização a ninguém, muito menos ao pai, não por falta de consideração à palavra deste, mas por não ter outro subterfúgio linguageiro para que fizesse surgir de si uma mãe, falando com seu filho, e não do seu filho, reconhecendo e nomeando aquele pequeno ser como sendo o seu bebê que recebeu do seu homem, e ao mesmo tempo, bebê que "deu a ele". Lembremos, havendo demanda, uma mulher costuma prometer ao homem a quem dirige sua atenção de mulher, "dar-lhe filhos": "Vou te dar um filho..." enquanto o homem, por sua vez, muitas vezes formaliza seu desejo "Quero um filho seu" - e não de outra qualquer.

Sendo assim, o lugar vazio discursivo ocupado por uma mulher de carne e osso a falar ao filho como mãe, não deixa de representar, também, a cultura, a Lei, pois se ela "gasta" seu tempo com o filho em atos que extrapolam os objetivos crus da maternagem, com temperos de libido e desejo, é porque algo lhe falta, dando provas de castração, de ser nãotoda. Não esqueçamos: as dimensões do real, do simbólico e do imaginário, segundo Lacan, estão sempre atadas, como no nó borromeu, cuja "liga" é dada pelo objeto $a$, essa porção de real que resiste à significação. Privilegiar o valor da função paterna parece querer privilegiar a dimensão simbólica, em detrimento dos outros dois registros, o que não parece correto, pelo menos em termos da estrutura do funcionamento inconsciente, se quisermos ser coerentes com o modelo proposto por Lacan, uma vez que o nó borromeu também é um modelo, criado para representar o funcionamento da linguagem.

E então ecoamos nosso mal-estar ao de Kamers, quando nos interessa pensar a figura do educador ora inclinado-se a um, ora a outro extremo, na reedição dessas funções fundadoras de subjetividade, independentemente do educador habitar seu corpo como homem ou mulher. É possível, por exemplo, um homem inscrever-se como agente de 
alienação para um educando e, em contrapartida, uma mulher como agente da interdição, da separação? Ou melhor, encarnarem ambos, ao mesmo tempo, as duas possibilidades?

Nossa intenção foi mostrar que sim, porque em nosso entender, por um lado, o educador não só pode, como deve, desejar e provocar a demanda do educando oferecendo para isso, além de suas palavras enunciadas, um aceite, uma escuta, que nada mais é do que uma oferta de reconhecimento do desejo desse sujeito educando, mas também de antecipação, de suposição, mesmo que este o faça invertendo a demanda educativa, o que não é nada ruim, porque demonstra uma resistência em ofertar-se como objeto ao desejo-dopedagogo - apesar de exigir do educador um gesto, a posteriori, de restrição. Porque o risco é fazer desse lugar de aceite, um lugar de alienação, o que incorreria no perigo de fixar o pêndulo nesse imaginário, onde o aluno figuraria como objeto a ser devorado, seja pelo furor pedagógico do educador, seja pelo furor diagnóstico dos para-educadores, que se põem a discursar sobre ele, mostrando-lhe o caminho - muitas vezes cínico - para adotar e usufruir dos direitos do desejo-do-cafécomleite, que também poderia ser chamado desejo-denãosercastrado, desejo-de-nãoassujeitar-se, desejo-de-serforadaLei, desejo-de-nãosujeito, desejo-de-nãodesejar, desejo-de-encarnarobjeto-falo, desejo-de-serofalo.

- Serofalo, serofante, seronãofalante, serinfans. Jogo de palavras e linguagem, desejo-de-manterseinfans. Haverá Paradeiro ${ }^{159}$ para essa tautologia, dentro e fora de nós?

Haverá paradeiro para o nosso desejo

Dentro ou fora de um vício?

Uns preferem dinheiro

Outros querem um passeio perto do precipício

Haverá paraíso

Sem perder o juízo e sem morrer?

Haverá pára-raio

Para o nosso desmaio

Num momento preciso?

Uns vão de pára-quedas

Outros juntam moedas antes do prejuízo

Num momento propício

Haverá paradeiro para isso?

Haverá paradeiro

Para o nosso desejo

Dentro ou fora de nós?

Haverá paraíso

Sem perder o juízo e sem morrer?

${ }^{159}$ Arnaldo Antunes 
Então, como não devemos condenar educando nenhum ao "paraíso", nem encaminhá-los ao salão do laissez-faire - espécie de portão de embarque para o primeiro - , sempre que se anunciar e o educador esteja disposto a um inexorável dispêndio maior de energia psíquica, deve implicar-se na restrição desse gozo do educando, buscando interditar aquilo que, por conta da transferência, não tem como não retornar do infantil e ser endereçado ao mestre, com ou sem louvor. Infantil sempre meio mal recalcado, como ocorre também ao educador, mas que se transmuta em gozo se não for cortado, ou pior, se encontrar um espelho para refletirem-se "Ah, coitadinho, leva consigo tantas dificuldades de aprendizagem"... nada mais é do que um incesto revisitado, embora agora no âmbito da res pública.

Desta forma, acreditamos, caso o educador não renuncie - por inibição ou crença psicometodológica - frente ao dever de tentar interditar o gozo, possivelmente acabará equacionando a impossibilidade do educar e, com acréscimo, inscrever alguma diferença simbólica no psiquismo do educando, esta que é uma parte da oscilação que deve sustentar entre o azeitar de um sim e o escoicear de um não. Ambos mecanismos em função simbólica, cujo pivô é o desejo em causa, mas não o Nome-do-Pai, como veremos a seguir.

Um certo Miguilim morava com sua mãe, seu pai e seus irmãos, longe, longe daqui, muito depois da Vereda-do-Frango-d'Água e de outras veredas sem nome ou pouco conhecidas, em ponto remoto, no Mutúm. No meio dos Campos Gerais, mas num covoão em trecho de matas, terra preta, pé de serra. Miguilim tinha oito anos. Quando completara sete, havia saído dali, para ser crismado no Sucurijú, por onde o bispo passava. Da viagem, que durou dias, ele guardara aturdidas lembranças, embaraçadas em sua cabecinha. De uma, nunca pôde se esquecer: alguém, que já estivera no Mutúm, tinha dito: - "É um lugar bonito, entre morro e morro, com muita pedreira e muito mato, distante de qualquer parte; e lá chove sempre..."

Mas sua mãe, que era linda e com cabelos pretos e compridos, se doía de tristeza de ter de viver ali. Queixava-se, principalmente nos demorados meses chuvosos, quando carregava o tempo, tudo tão sozinho, tão escuro, o ar ali era mais escuro; ou mesmo na estiagem, qualquer dia, de tardinha, na hora do sol entrar. - "Oê, ah, o triste recanto..." - ela exclamava. Mesmo assim, enquanto esteve fora, só com o tio Terêz, Miguilim padeceu tanta saudade, de todos e de tudo, que às vezes nem conseguia chorar, e ficava sufocado. (...) Gostava de tio Terêz, irmão de seu pai.

Quando voltou para casa, seu maior pensamento era que tinha a boa notícia para dar à mãe: o que o homem tinha falado - que o Mutúm era lugar bonito... A mãe, quando ouvisse essa certeza, havia de se alegrar, ficava consolada. Era um presente; e a ideia de poder trazê-lo desse jeito, de cór, como uma salvação, deixava-o febril até nas pernas. Tão grave, grande, que nem o quis dizer à mãe na presença dos outros, mas insofrida por ter de esperar; e, assim que pôde estar com ela só, abraçou-se a seu pescoço e contou-lhe estremecido, aquela revelação. A mãe não the deu valor nenhum, mas mirou triste e apontou o morro; dizia: - "Estou sempre pensando que lá por detrás dele acontecem outras coisas, que o morro está tapando de mim, e 
que eu nunca hei de poder ver..." Era a primeira vez que a mãe falava com ele um assunto todo sério. No fundo de seu coração, ele não podia, porém, concordar, por mais que gostasse dela: e achava que o moço que tinha falado aquilo era que estava com a razão. Não porque ele mesmo Miguilim visse beleza no Mutum - nem ele sabia distinguir o que era um lugar bonito e um lugar feio. Mas só pela maneira como o moço tinha falado: de longe, de leve, sem interesse nenhum; e pelo modo contrário de sua mãe - agravada de calundu e espalhando suspiros, lastimosa. No começo de tudo, tinha um erro - Miguilim conhecia, pouco entendendo. Entretanto, a mata, ali perto, quase preta, verde-escura, punha-lhe medo (...)

- Pai está brigando com Mãe. Está xingando ofensa, muito, muito. Estou com medo, ele queria dar em Mamãe. (...)

- Eu acho, Pai não quer que Mãe converse mais com o tio Terêz... Mãe está soluçando em pranto, demais da conta.

Miguilim entendeu tudo tão depressa, que custou para entender. Arregalava um sofrimento. (...)

(...) - "Mãe, que é que é o mar, Mãe? Mar era longe, muito longe dali, espécie duma lagoa enorme, um mundo d'água sem fim, Mãe mesma nunca tinha avistado o mar, suspirava. - Pois, Mãe, então mar é o que a gente tem saudade? Miguilim parava, Drelina espiava em sonho, da janela. Maria Pretinha e a Rosa tinham vindo também. (...)

(...) Miguilim de repente começou a contar estórias tiradas da cabeça dele mesmo (...) Essas estórias pegavam. Mãe disse que Miguilim era muito ladino, depois disse que o Dito também era. Tomezinho desesperou, porque Mãe não tinha escapado de falar no nome dele; mas aí Mãe pegou Tomezinho no colo, disse que ele era um fiozinho caído do cabelo de Deus. Miguilim, que bem ouviu, raciocinou apreciando aquilo, por demais. Uma hora ele falou com o Dito - que Mãe às vezes era a pessoa mais ladina de todas. (ROSA, 2001, p. 27-104).

\subsection{Da função paterna ao Nome-(im)próprio}

Duas perguntas que esbarram na ordem do que é impossível de ser formatado e respondido a contento atravessam os questionamentos psicanalíticos. Menos por uma questão de "cavalheirismo" ou, simplesmente, de civilidade e mais porque aquela que se faz mãe ocupa o lugar estrutural de Outro Primordial, transportando no corpo o que muitos chamam de "receptáculo do pênis" - a bainha da espada, o "estojinho encantador que elas não elevam ao significante" (LACAN, 2003, p. 465), A Origem do Mundo ${ }^{160}-$, este foi o motivo

\footnotetext{
160 Òleo sobre tela, de 1866, de Gustave Courbet (1819-1877), adquirida por Jacques Lacan a pedido de sua mulher, a atriz Sylvia Battaille. Segundo o jornalista Jorge Pontual e também o professor Jorge Coli (Unicamp), esta famosa e perturbadora tela que hoje pode ser vista no Museu D'Orsay, em Paris, foi pintada sob encomenda de um milionário diplomata turco, Khalil-Bey, para fazer parte de sua coleção de arte erótica.
} 
para nos dedicarmos, em primeiro lugar, à função materna e, com ela, ao interrogante nãoresolvido "O que quer uma mulher?", que Contardo Calligaris desdobra em "Como será que ela goza?""161 , admitindo como resposta plausível, embora um tanto tautológica, impalpável e enigmática, a de Colette Soller : gozar o quanto deseja. Espécie de reediçãoporque não mera repetição do mesmo - daquilo que Lacan entendeu descobrir como "o acesso que leva da sexualidade feminina ao desejo" (LACAN, 1998, p. 744), desejo que não é o da passividade do ato, senão o que surge "como o esforço de um gozo envolto em sua própria contiguidade (da qual toda circuncisão talvez indique a ruptura simbólica), para se realizar rivalizando com o desejo que a castração libera no macho, dando-lhe seu significante no falo" (Idem, ibidem). O que a nós transparece, nesse desejo da mulher de gozar desmesuradamente - o quanto deseja -, a forja, a urdidura da mulher que lhe permite empunhar e ofertar "falicamente" ao homem, como uma ostentação, nada menos que a sua capacidade de gozo em série, tanto no real, quanto na realidade, o que arriscamos configurar em contraponto à "inveja do pênis”, “a inveja da potência de gozar em série, o quanto desejar”. E só assim, talvez, possamos entender porque Coutinho Jorge (2005, p. 52) afirma que o desejo-da-mãe tenha por função simbólica a transmissão do Nome-do-pai, quando Lacan já havia dito que o desejo-da-mãe só não se torna fatal, caso haja em sua bocarra voraz um rolo de pedra em potência para ser colocado.

Khalil-Bey teria ficado com ela, em seu banheiro, oculta por uma cortina, até vendê-la em segredo, pois o quadro, apesar de Courbet ser um artista bastante polêmico na época, jamais havia sido exposto. "A história deste quadro dava um filme (...). Depois de o diplomata otomano o ter recebido de Courbet e o ter acrescentado à sua colecção no seu palácio no Boulevard Haussman - onde, ao que dizem, apenas o mostrava aos seus amigos e visitantes mais íntimos -, o quadro desapareceu na dispersão que se seguiu à ruína de Khalil-Bey, em 1868, tendo certamente servido para pagar algumas das suas dívidas. Sabe-se que $A$ origem do mundo esteve guardado durante vários anos no castelo de Blonay. Em 1913, reapareceu numa galeria de Paris, onde foi adquirido por um barão húngaro, François Hatvany, coleccionador de arte, que o levou para o seu palácio de Budapeste. Voltou a desaparecer no tumulto da Segunda Guerra Mundial e a ressurgir, de novo na capital francesa, nos anos 50, indo parar nas mãos de Sylvia Bataille, primeira mulher de Georges Bataille (autor do livro O Erotismo), depois casada com o psicanalista Jacques Lacan (...). O casal Lacan manteve a tela guardada na sua casa de campo ao longo de décadas, (...) sobrepondo-lhe, numa porta de correr, de madeira, [a tela surrealista encomendada a André Masson, em frente à qual - reza o mito? - , Lacan posicionava seus convidados ilustres para, sem avisá-los, deslizar o quadro de Masson e expor-lhes, de sopetão, suA Origem do Mundo enquanto, concomitantemente, observava-lhes a reação, numa espécie de jogol e em certo sentido, na materialização da teoria de Bataille, que dizia que o erotismo está não naquilo que se mostra, mas naquilo que se esconde. (...) [Fazendo referência ao sorriso enigmático da Mona Lisa no Louvre] (...) o jornalista do Libération, Gérard Lefort, escreveu que $A$ origem do mundo, segundo quadro mais famoso do mundo, seria "a Mona Lisa do sorriso vertical" (ANDRADE, 2007, p. 6-7, acréscimos nossos). Anexos D, E, F.

161 “O que será que uma mulher quer? Como será que ela goza?” In: A invenção do clitóris : 'O Anatomista' narra como Mateo Colombo descobriu o pequeno órgão feminino (resenha do livro) . Disponível em:

http://webcache.googleusercontent.com/search?q=cache:-

4rJkABO03gJ:contardocalligaris.blogspot.com/1997_07_01_archive.html+a+vagina + recept $\% \mathrm{C} 3 \% \mathrm{~A} 1 \mathrm{culo}+\mathrm{do}+\mathrm{p}$ $\% \mathrm{C} 3 \% \mathrm{AAnis}+\mathrm{freud} \& \mathrm{~cd}=4 \& \mathrm{hl}=\mathrm{pt}-\mathrm{BR} \& \mathrm{ct}=\mathrm{clnk} \& \mathrm{gl}=\mathrm{br} \&$ source=www.google.com.br. Acesso em 16/02/2011. 
E então será a vez de nos voltarmos à segunda pergunta, segundamente primordial: $\mathrm{O}$ que é o pai?

Neste rodear que faremos a partir de agora - o último, graças a Deus! - , partiremos do Nome-do-Pai ${ }^{162}$ ao falarmos da função paterna para, enfim, chegarmos ao Nome(im)próprio, como designamos o outro extremo pendular, em oposição ao desejo-dopedagogo.

O Nome-do-Pai é o

Produto da metáfora paterna que, designando primeiramente o que a religião nos ensinou a evocar, atribui à função paterna o efeito simbólico de um puro significante e que, em um segundo momento, designa aquilo que rege toda a dinâmica subjetiva, ao inscrever o desejo no registro da dívida simbólica (J.P. Hiltenbrand, in: CHEMAMA ; VANDERMERSCH, 2005, p. 268).

Segundo Hiltenbrand, o pai é uma verdade sagrada, da qual, no entanto, nada na realidade vivida indica a função, tampouco a dominância, porque continua sendo, em primeiro lugar, uma verdade inconsciente. Sendo assim, foi por meio de uma elaboração mítica que a função paterna surgiu na psicanálise e que atravessou toda a obra de Freud, quando em sua última obra, Moisés e o Monoteísmo, o autor desenvolveu a eficácia inconsciente como sendo a do pai morto, enquanto termo recalcado, relacionando-o às noções de destino e de providência. Assim, se o Nome-do-Pai é um conceito fundamental da psicanálise,

\footnotetext{
${ }^{162}$ Segundo Roudinesco e Plon, esse conceito não tem, na doutrina lacaniana, o mesmo estatuto dos demais. Com efeito, não foi retirado de um corpus existente. Tem sua fonte primordial e inconsciente na vida de Lacan e em sua experiência pessoal e dolorosa de paternidade. Primeiro como filho, ele teve de suportar as falhas de seu pai, Alfred Lacan (1873-1960), esmagado pela tirania de seu próprio pai, Émile Lacan (1839-1915). Em seguida, havendo-se tornado pai pela quarta vez em julho de 1941, nos tempos mais sombrios da Ocupação, Lacan não pôde dar o seu nome a sua filha, que foi registrada em cartório com o sobrenome Bataille, uma vez que sua mãe, Sylvia Bataille (1908-1993), ainda era esposa legítima de Georges Bataille (1897-1962). Esse imbróglio infernal do nome do pai, decorrente da legislação francesa sobre a filiação, duraria até 1964 e o mergulharia, como manifestou Lacan em diversas vezes, numa culpa terrível. (...) Tal como Sigmund Freud, Lacan foi acossado pela questão da paternidade. Em 1938, em seu artigo magistral sobre a família, mostrou que a psicanálise nascera, em Viena, de um sentimento de declínio da imago paterna e da vontade freudiana de revalorizá-la. Lacan adotou o mesmo modelo de reformulação simbólica da paternidade, embora integrando as teses kleinianas referentes às relações arcaicas com a mãe. (...) Apoiando-se num livro de Claude Levi-Strauss, (...) Lacan mostrou que o Édipo freudiano podia ser pensado como uma passagem da natureza para a cultura. Segundo essa perspectiva, o pai exerce a função essencialmente simbólica: ele nomeia, dá seu nome, e, através desse ato, encarna a lei. Por conseguinte, se a sociedade humana, como sublinha Lacan, é dominada pelo primado da liguagem, isto quer dizer que a função paterna não é outra coisa senão o exercício de uma nomeação que permite à criança adquirir sua identidade. (...) Em 1956, quando de seu seminário sobre as psicoses e seu comentário sobre a paranoia de Daniel Paul Schreber, (...) [evocou] a naturreza da relação de Daniel Paul Schreber com o pai, e fez da psicose do filho uma "foraclusão do nome-do-pai". Mais tarde, estendeu esse protótipo à própria estrutura da psicose. (...) Lacan foi o primeiro dos comentadores de Freud a teorizar o vínculo existente entre o sistema educacional de um pai e o delírio de um filho (ROUDINESCO ; PLON , 1998, p. 541-542, acréscimo nosso)
} 
(...) isso se deve ao fato de que o que o paciente vem buscar no tratamento é o tropo de seu destino, isto é, aquilo que, da ordem da figura de retórica, irá comandar seu devir. A esse título, Édipo e Hamlet são exemplares. Isso seria dizer que a psicanálise convidaria a um domínio desse destino? Tudo vai contra essa ideia, à medida que o Nome-do-Pai consiste, principalmente, na regulação do sujeito com seu desejo, em relação ao jogo dos significantes que o animam e constituem sua lei (idem, ibidem).

$\mathrm{Na}$ metáfora paterna, estariam formalizados dois tempos para a substituição de significantes. O primeiro deles, a elisão do desejo da mãe, substituindo-o pela função do pai, naquilo que ela conduz, atravéz do apelo ao seu nome, à identificação com o pai e à extração do sujeito para fora do campo de desejo da mãe. Esse primeiro tempo seria aquele que condiciona a estrutura neurótica, resultante da inscrição de um sujeito, por meio do recalcamento originário.

No segundo tempo, o Nome-do-Pai, enquanto significante, vai duplicar o lugar do Outro inconsciente. Ele dramatiza, em seu justo lugar, a relação com o significante fálico, originalmente recalcado, e institui a fala, sob os efeitos do recalcamento e da castração simbólica, condição sem a qual um sujeito não conseguiria assumir validamente seu desejo na ordem de seu sexo (Idem, ibidem, p. 269).

A partir disso, segundo o autor, decorrem diversas consequências. Sendo a metáfora um sentido novo, o Nome-do-Pai acaba assumindo uma significação diferente.

Se o nome inscreve, primeiro, o sujeito como elo intermediário na sequência de gerações, esse nome, enquanto significante intraduzível, suporta e transmite o recalcamento e a castração simbólica. Com efeito, o Nome-do-Pai, vindo ao lugar do Outro inconsciente simbolizar o falo (originalmente recalcado), ele duplica, por conseguinte, a marca da falta no Outro (que é igualmente a do sujeito: seu traço unário) e, pelos efeitos metonímicos ligados à linguagem, ele institui um objeto causa do desejo. Assim, se estabelece, entre o Nome-do-Pai e objeto, causa do desejo, uma correlação que se traduz pela obrigação, para um sujeito, de inscrever seu desejo segundo a ordem de seu sexo, reunindo sob esse nome, o Nome-do-Pai, e ao mesmo tempo a instância do desejo e a Lei que o ordena, ao modo de um dever a ser cumprido (Idem, ibidem, $\mathrm{p}$. 269).

Tal dispositivo, afirma ainda o autor, distingue-se radicalmente da simples nomeação, porque o Nome-do-Pai significa que o sujeito assume seu desejo como de acordo com a lei do pai, ou seja, a castração simbólica, assim como também as leis da linguagem. A falta eventual desta última operação se traduz, clinicamente, pela inibição ou pela impossibilidade de dar seguimento ao desejo, em suas consequências, sejam afetivas, intelectuais, profissionais ou sociais. 
De acordo com Roudinesco, quando Lacan elaborava o conceito de foraclusão ${ }^{163}$, concomitantemente teorizava a noção de Nome-do-Pai, utilizada desde 1953, mas somente formulada enquanto conceito em 1956.

A isto juntava-se também o estabelecimento definitivo dos dois termos grande Outro e pequeno a, um introduzido pela primeira vez em 25 de maio de 1955, o outro já empregado desde 1936, mas doravante situado num quadro binário: $\mathrm{A} / \mathrm{a}^{164}$. Do inconsciente como "discurso do outro", tal como era definido em Roma ${ }^{165}$, Lacan passava, em sua segunda retomada, a um inconsciente como "discurso do Outro". Quanto ao pequeno a, lugar do eu imaginário, ele tornava-se a questão de um resto, preso no real e não simbolizável: objeto como falta e objeto como causa de desejo. Para rebaixar o eu à posição de dejeto, Lacan recorria aqui à heterologia cara a Georges Bataille, a qual servia de garantia para que a estrutura lacaniana não fosse a reintrodução de um Deus sob a máscara de uma transcedência, tão temida por Lévi-Strauss (ROUDINESCO, 2008, p. 387).

Sendo assim, para conceber a binaridade $\mathrm{A} / \mathrm{a}$, entendeu como necessário fazer a distinção entre $e u$-ideal e ideal do eu, distinção que não existia no sistema tópico freudiano, no qual “(...) Ideal-Ich, traduzido em francês pelo vocábulo moi-idéal, era uma formação intrapsíquica que designava o ideal de onipotência narcísica do sujeito, forjado sobre o modelo do narcisismo infantil" (Idem, ibidem).

Posteriormente a Freud, em 1932, Hermann Nunberg introduziu uma cisão nessa conceitualidade, fazendo do eu-ideal (Ideal-Ich) uma formação geneticamente anterior ao supereu. Ao longo de sua evolução, disse ele, o sujeito deixa atrás de si seu ideal narcísico, embora aspirando a retornar a ele, especialmente nas psicoses (Idem, ibidem).

Então, em março de 1954, teria sido a partir do debate sobre o narcisismo entre Freud e Jung, sem citar Nunberg, que Lacan faria a distinção, à sua maneira - e isso é importante, porque estamos indo em direção ao Nome-(im)próprio - do eu ideal e do ideal do eu.

Definia o primeiro termo como uma formação narcísica pertencente ao registro do imaginário e que tinha sua origem no estádio do espelho, e o segundo como uma função simbólica capaz de organizar o conjunto das relações do sujeito com o outrem. Assim, o estabelecimento da dualidade A/a

\footnotetext{
${ }^{163}$ Em 4 de julho de 1956, na última sessão de seu seminário dedicado às psicoses e à leitura do comentário de Sigmund Freud sobre a paranóia do jurista Daniel Paul Schreber (ROUDINESCO ; PLON, 1998, p. 245).

${ }^{164}$ Lembremos que "outro", em francês, esceve-se "autre", cujas acepções podem deslizar semanticamente em outros dois sentidos: diverso e anterior (cf. CORRÊA, 1961, p. 59).

${ }^{165}$ Discurso de Roma : proferido em 26 de setembro de 1953, para introduzir o relatório "Função e campo da fala e da linguagem em psicanálise”. In: Outros Escritos, 2003.
} 
era consecutiva à instauração do dualismo Ideal do eu e do eu ideal ${ }^{166}$ (Idem, ibidem, p. 388).

Nesse sistema, segundo a autora, Lacan conseguia introduzir a clivagem lévistraussiana da universalidade do incesto como passagem da natureza à cultura, o que por sua vez possibilitava pensar uma oposição entre a função simbólica do pai, representante da cultura e encarnação da Lei, e a posição imaginária da mãe, dependente da ordem na natureza e condenada a fusionar-se com o filho, como objeto fálico de um pênis faltante - ideia que já desdobramos anteriormente.

Daí a ideia lacaniana da fase edipiana entendida como passagem da natureza à cultura. Se a sociedade humana é dominada pela linguagem (o Outro, o significante), isso quer dizer que o polo paterno ocupa, na estruturação histórica de cada sujeito, um lugar análogo. Em sua primeira retomada, Lacan define este como função do pai, depois como função do pai simbólico, em seguida como metáfora paterna, para finalmente designar a função ela mesma, em sua segunda retomada, como um conceito: o nome-do-pai. (...) "A função de ser pai", dizia, "não é de modo nenhum pensável sem a categoria do significante" ${ }^{167}$. Nessa perspectiva, a passagem edipiana da natureza à cultura se dá do seguinte modo: sendo a encarnação do significante por nomear o filho com seu nome, o pai intervém junto deste como privador da mãe, dando origem a seu ideal do eu (Idem, ibidem, p. 388).

Não iremos rever neste escrito todo este desenvolvimento conceitual de Lacan mas, por contê-lo, referenciamos A função do pai em psicanálise: para que serve a autoridade? (função e deriva na modernidade), de Luiz Fenando Belmonte Mena (IPUSP, 2004), utilizada para o desdobramento de nossa inferências.

Segundo Mena (2004, p. 122), se tormarmos a função do pai ainda que não afastada dos conteúdos imaginários colados à figura paterna sob a forma de onipotência, dominação e tirania - descritos por Freud em Totem e Tabu -, sem ainda transcender, num segundo momento, o aspecto imaginário da própria interdição como operação significante descrita por Lacan, já será importante evocar o pai interditor, por duas razões: primeiro, porque é uma forma de proteger a criança do risco de morte e/ou acidentes, quando os adultos limitam o raio de ação das crianças para todo tipo de "tonterias": colocar o dedo na tomada, beber

\footnotetext{
${ }^{166}$ A esse respeito, Lajonquière explica: o eu ideal é um mandato imaginário, feito de puro estofo especular, para formatar a falta do/no sujeito, de modo que acaba se revelando um voto de gozo, porque nada mais é do que um pedido de complementação narcísica daquele que o enuncia, veiculando um saber mais parecido com a certeza; em contrapartida, o ideal do eu veicula não um mandato de uma certeza, mas um saber-não-sabido, uma dívida simbólica, por isso de dever ser, contraída por conta da filiação a uma tradição existencial, no passado, com outros sujeitos, que possuem estas mesmas insígnias, já que também um dia filiaram-se a determinada tradição (a matemática, a filosofia, as línguas estrangeiras, a química, enfim...) (cf. LAJONQUIÈRE, 1997, p. 32-33).
}

${ }^{167}$ LACAN, J. Séminaire III : Les psychoses. Paris: Seuil, p. 329. 
líquidos venenosos, atravessar a rua sozinho, jogar-se na água sem saber nadar, aproximar-se de lugares altos de onde pode cair, entre outras ações que representam riscos reais à sua integridade física; em segundo, quanto a saúde psíquica:

(...) o pai é aquele que interdita à criança um gozo autístico, impedindo-a de gozar indefinidamente, à sua própria sorte, com o próprio corpo, com o corpo da mãe, com o mundo, como se fossem objetos a seu dispor, extensões de seu corpo. Ao colocar uma lei, uma ordem, uma interdição, o pai protege a criança de se ver morta como sujeito, livrada ao mundo da natureza, à alienação ao espelho do outro e ao perigo de se ver, assim, eternamente capturada como objeto do gozo do outro. Como sujeito desejante, como mandatário do Outro, da lei do Outro, é conferida ao pai essa tarefa de limitar o gozo que aliena a criança, levando-a ao mundo da cultura, ao mundo do Outro (MENA, 2004, p.122-123).

Então o autor segue como uma pergunta de Jacques Allan Miller que também nos interessa, porque leva ao pequeno $a$ : "O que nos restaria após a interdição do incesto?" O objeto proibido, esse que se tornará o objeto perdido. O resto. Por isso que a Lei, após Freud, mostra-se a favor do desejo - e não contra ele, como talvez muitos psicopedagogos ortodoxos possam imaginar e denegar - justamente porque dá suporte e sustentação ao que é proibido, interditado, não-dito. “O nó do desejo é a Lei” (Idem, ibidem, p. 123).

E poderia ser um outro, que não o pai da realidade, o agente inteditor? Sim, responde Mena, mas apenas um elemento terceiro que intervenha como terceiro na relação entre mãe e filho para poder realizar tal função. "Todo teceiro que responde a esta função mediatizando os desejos respectivos da mãe e do filho vai instituir, por sua incidência, o alcance legalizador da interdição do incesto" (DOR, 1991. p. 42). Entretanto, tal qual apontou Kamers para aquela que não haveria de ser uma "qualquer mãe", o mesmo ocorre aqui para esse suposto “qualquer pai”, já que também não será um qualquer, a não ser aquele “qualquer” para quem os olhinhos da mãe, ao tirar os olhos do seu pequeno falo - o bebê - ganhará um brilho enigmático, isto que sela a palavra desse pai, para essa mãe e que é, também, um lastro.

Trata-se menos das relações pessoais entre o pai e a mãe (...) que do momento que tem que ser vivido como tal, e que concerne às relações não apenas da pessoa da mãe como a pessoa do pai, mas da mãe com a palavra do pai (LACAN, 1957-58, p. 197).

Desta feita, voltamos a reentender Coutinho Jorge (2005, p. 52) em sua afirmação sobre a função simbólica do desejo-da-mãe enquanto transmissão do Nome-do-pai. O pai pode e deve transmitir o "não", mas é somente a mãe, perante o filho e para ele, que fará a transmissão desse lugar que deve ser escutado e levado em consideração: “ - Escute seu Pai!”. A interdição paterna, sem o aval da mãe, sem o seu reconhecimento, é palavra vazia, palavra 
morta. Se a palavra legitimadora, então, é a dela, ou seja, se a legitimidade ao pai que parecem dar é à mãe-mulher, poderia, então, só a mãe ser a portadora da palavra que faz lei? Segundo Lacan (idem, ibidem, p. 193), sim, mas uma lei não mediada, uma lei não controlada, ou seja, uma lei caprichosa, porque não se refere a um terceiro e foi erigida sem a intemediação do Outro, ou seja, é uma lei fundamentada no próprio sujeito que a sustenta.

Certamente basta que o significante Nome-do-Pai seja convocado pelo discurso da mãe para que a função mediadora do Pai simbólico seja estruturante. Mas é necessário, ainda, que este significante Nome-do-Pai seja explicitamente, e sem ambiguidades, referido à existência de um terceiro, marcado pela diferença sexual relativamente ao protagonista que se apresenta como mãe. É só nessas condições que, na ausência do pai real, o significante Nome-do-Pai pode ter todo o seu alcance simbólico (DOR, 1991, p. 58).

Assim, fica claro porque tivemos que mudar, também, a designação do outro extremo pendular da função do educador - aquela que deve impor o ponto de basta, restringindo o educando, funcionando como um interditor de gozo - , pois a estrutura do ato educativo não é semelhante à estrutura familiar, ou seja, o educador é um só sujeito para pendular entre dois extremos que, apesar de poderem reeditar as funções subjetivantes, não são em si um homem, nem uma mulher-mãe. Ou seja, a questão do pêndulo educativo não está posta, nem é dependente, de um real marcado pela diferença sexual entre o desejo-do-pedagogo e o Nome-(im)próprio, embora um esteja para o outro de maneira semelhante ao que ocorre entre uma mãe e um pai. Ou seja, o Nome-(im)próprio é o que fará, em certo sentido, que o próprio educador imponha a interditação às "tonterias" do educando, mas também, lembrará ao desejo-do-pedagogo, principalmente quando este tomar lugar de todo saber sobre o educando, que este não deve ser feito seu objeto de gozo. Gozo de tudo saber, tudo controlar, tudo prever, tudo acertar. Mas por que o desejo-do-pedagogo "escutaria" esse mandato, essa imposição, levando em conta esse ponto do Nome-(im)próprio? Porque na verdade, implicarse na função educadora é exatamente isso, é dedicar-se a essa perlaboração dos seus próprios e impróprios atos educativos e não-educativos, quando é preciso que o educador reconheça que passou do ponto, que apertou ou afrouxou de mais "a volta do parafuso". Mas até chegarmos aí, há ainda alguns trechos a percorrer.

Segundo Mena, a utopia daquela que denominou pedagogia clássica, é que a aprendizagem seja um processo meramente cognitivo, tal qual o ensino, de tal forma que o professor, quando sabe bem a matéria a ensinar, consegue fazer que os alunos aprendam, sem haver maiores contratempos, sem que haja restos, ou seja, sem que haja gozo, nem do educando, nem do educador - a educação ideal! Seria como um ensino-aprendizagem 
asséptico, sem arestas, dizemos nós. O problema, é que entre sujeitos, as coisas não funcionam assim, mas sempre meio "sujas", meio "melecadas" pelos restos do que não se consegue entender bem por quê. Restos de real, aquele mesmo que vem enodado no nó borromeu, motivo pelo qual a assepsia no campo educativo é mesmo uma utopia. A instância da letra na aprendizagem ${ }^{168}$ ? Sim, visto que o ato educativo envolve uma porção de gozo, de resto, de pura letra, que precisa ser levada em consideração, para justamente se pôr a tentar inventar o que fazer com ela, mesmo que, por um tempo, seja nada fazer, até que nos ocorra algum outro tentar. Lembremos apenas o seguinte, sentar à beira do caminho após ter constatado que nos deparamos, depois de nomeá-la, com a instância da letra no aprender, de pouco vale, a não ser para fazer do conhecimento psicanalítico exatamente mais um significante técnico inoperante, senão reconfortador para uma tomada de posição impotente do tipo "não há o que fazer". Então atentemos, para algumas das acepções que o Houaiss fornece para "tentar" e vejamos como nos faz lembrar o movimento de uma mãe em desejo pelo seu bebê suposto sujeito, embora infans: empregar meios para conseguir (algo); diligenciar, intentar; esforçar-se por; buscar, procurar; pôr em execução; empreender, realizar; pôr em experiência; provar, testar; exercer uma prática; experimentar, exercitar; despertar vontade em alguém para fazer algo; instigar, induzir ou seduzir; atentar; deixar-se seduzir; estar próximo a ceder à tentação.

Uma das funções do educador, entendemos, não é ser assertivo - embora até o possa -, mas encarnar um sujeito que tente, que invente, que se apraze em circular o toro, o real, no aprender e no ensinar, como se andasse sobre a face de uma fita de Moebius ${ }^{169}$ à procura de uma pequena brecha, uma pequena porta subjetiva, por onde possa tentar inocular, exatamente ali, meio sem-querer-querendo, sabe-se lá quando e como, o pequeno $a$, ou se preferirmos, algum espectro dos "conteúdos programáticos do currículo", o que talvez não passe mesmo de um pretexto subjetivante, retirado sabiamente do estofo da cultura.

Como fazer isso?... bem, o agalma é uma maneira... o brilho no olhar, outra... o humor, outra... os cheiros, as cores, os sons, a prosódia, as roupas, os sapatos, as mãos... outras... enfim, essas coisas todas que devem aprender a inventar e usar cada e cada

\footnotetext{
${ }^{168}$ Referência ao texto de Jean Bergès, publicado pela Revista da Associação Psicanalítica de Porto Alegre (APPOA), ano IX, n. 16 - julho de 1999, mas também ao texto "A instância da letra no inconsciente ou a razão desde Freud" (LACAN, 1998, p. 496-533).

169 Faixa de Möbius/ Fita de Moebius: Figura topológica que fornece a intuição muito simples de um objeto unilátero, e a partir da qual Lacan pôde esclarecer, em particular, a relação do consciente como inconsciente, assim como o funcionamento da interpretação. (...) Pode-se construí-la muito simplesmente, tomando uma tira de papel e, colando suas extremidades depois de ter efetuado uma troção de meia volta (CHEMAMA ; VANDERMERSCH, 2005, p. 251).
} 
educador, pois não estamos aqui com o propósito de escrever dicas, nem de suavizar o caminho das pedras, talvez, no máximo, de aventar a possibilidade de uma pedagogia mais interessante e menos aprisionada nas ortodoxias costumeiras.

Percebemos que o ideal da pedagogia, esse que tenta universalizar o sujeito do conhecimento, ao propor métodos universais de aprendizagem, não dá conta de tudo. É também por isso que não resolve o problema os pais serem "aconselhados" por um psicólogo sobre a "maneira correta" de educar. O caso a caso do sujeito escapa à pedagogia, exatamente porque a pedagogia não permite que os sujeitos incluam no processo educativo suas versões de gozo (MENA, 2004, p.129).

- Mas terá que ser sempre assim? Não seria possível ensi(g)nar aos pedagogos como dançar um iê-iê-iê?

Enfim, o que queremos dizer é que a tarefa do pai não é somente simbólica, nem se reduz à interdição. Há um real em jogo, além do imaginário que, com o simbólico, fecham o nó [borromeu] (Idem, ibidem, p. 127, acréscimo nosso).

Se, entre o casal parental, o real está posto na diferença entre os sexos, onde está em jogo o real na estrutura educativa? Bem, tentamos argumentar que seja no estilo de endereçamento da palavra do educador assentado no pequeno $a$, embora possamos dizer que esteja posto, também, no estilo singular de aprender e escutar do educando, conforme havia indicado Kupfer (2001, p. 131-134), quando se referiu ao estilo meditativo do aluno, seu estilo cognitivo, o estilo que lhe é próprio. E então, já que falamos de agalma, na figura do educador, talvez possamos pensar na possibilidade de haver agalma também no educando, quando estivermos nos endereçando a ele. Aqui cabe um aparte de nossa clínica do aprender, que temos repetido a quem quiser escutar. A clientela que nos procura, em geral, vem com um significante pendurado na lapela: são "déficits". Entretanto, o que costumamos presenciar, em muitos casos, embora não em todos, o que ocorre é justamente o contrário, ou seja, deveriam ser falados como plus: plus no processamento cognitivo multivetorial (não restrito apenas ao âmbito escolar), nos recursos criativos, na sutileza da escuta, nos talentos para atividades como música, dança, esporte, e mesmo filosofia, já que muitos demonstram grande prazer pela atividade do pensar em si. Quando nos deparamos com esses sujeitos educandos, não é raro, costumamos nos perguntar, afinal, de quem é aquele déficit, pois, se alguém o porta, como uma necessidade realmente especial, com certeza foi o técnico que "viu” naquele sujeito o déficit e não o plus. Ou seja, o déficit, nesses casos, é de quem não tem como reconhecer que ali há, mesmo, um plus, um algo a mais, muito provavelmente da ordem de um gozo, a mais, um mais-de-gozar, mas isso que não é déficit, é um sintoma, e se 
for tomado e lidado como déficit, tende mesmo a se potencializar - em gozo. Gozo para si, ou seja, para o próprio educando e familiares, mas também para os que encarnam o desejo-depedagogo, que enfim acabam encontrando, mais uma e uma vez, aqui e acolá, seus bodesexpiatórios - espécies de lixeira de real, que a humanidade insiste em manter do lado de fora da casa, como se não tivesse nada a ver com elas, esperando pelo caminhão do lixo que, magicamente, fará desaparecer de seu entorno o material fétido e sem serventia. O problema é que todo esse material feito de restos, não irá evaporar, sumir como num passe de mágica, mas acabará mesmo em algum lixão, que no nível do discurso universitário psicopedagógico bem pode ser uma multidão de sujeitos "com problemas de aprendizagem", clientela segura para uma legião de para-educadores, instituições e indústria farmacêutica, todos especializados em "déficits".

Há uma acepção de estilo que não foi mencionada. Um estilo pode ainda ser
um vaso. Na Antiguidade, alguns povos modelavam grandes recipientes de
cerâmica e lá guardavam os documentos em que estavam registradas suas leis.
Lacan diz que, nos estilos, uma cultura guardava seus tesouros... Os estilos
são de fato tesouros do sujeito, que muitos deles desconhecem possuir. Nossa
árdua tarefa será, então, a de ajudar, remando contra a maré de muitos
discuros sociais, cada aluno a desenterrar o seu próprio tesouro (KUPFER,
2001, p. 132-133).

Ou seja, o real no campo educativo estará posto no estilo de processamento realimaginário-simbólico da palavra proferida e escutada, seja da perspectiva do educando, seja da perspectiva do educador. E como a palavra funciona pela lógica do significante, difícil é prever o que um e outro farão com aquilo que recebem - enquanto demanda -, e aquilo que ofertam - como efeito, como produção subjetiva -, motivo mais do que suficiente para nós, enquanto pedagogos não-ortodoxos, deixarmos de perder tempo e investimento público com aquisições tecnocientíficas que disponibilizam não mais do que meras ilusões prescritivas e reconfortadoras de formação, para nos voltarmos às invencionices - e, quando possível, se possível, também a estas ancoragens teóricas - que nos permitirão haver com o inesperado e o incompreensível estrutural da dinâmica educativa, que uns entendem como a instância da letra no aprender e nós, também, como a instância da letra no ensinar. "Perlaboração" : talvez este seja o avesso da função pendular do educador.

Mas voltemos a Mena, para pensarmos um pouco mais a respeito do gozo no educar. Segundo ele, podemos tomar diferentes funções do pai em psicanálise, analisando-as de acordo com os diferentes tipos de relação do sujeito ao Outro e respectivos acessos ao gozo. Seriam, assim, quatro "pais": 


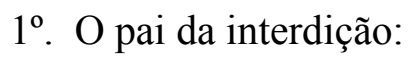

É o pai - ou educador - que busca no "não" autoritário um retorno nostálgico do antigo sistema educacional disciplinador, acreditando que uma ordem rígida é o que faltaria na educação de hoje em dia. Não é difícil acharmos instituições que se baseiam neste modelo de pai: os antigos colégios tradicionais, principalmente os colégios religiosos, baseiam sua função educativa na crença da repressão, na força do "não", na importância da punição, na vigilância panóptica. São as intituições disciplinares clássicas, descritas por Michel Foucault em Vigiar e Punir. O pai, o professor, o mestre, instituído neste lugar de saber e poder, seria o único que goza, interditando toda e qualquer possibilidade de gozo aos filhos ou alunos (MENA, 2004, p. 128);

$2^{\circ}$. O pai como educador benevolente:

O pai que surge como reação aos modelos autoritários tradicionais é o pai benevolente, o pai do discurso científico, politicamente correto. Qual seria a função do pai aqui? Propiciar ao filho um gozo sem entraves, assegurado por uma educação sem restrição ou interdição. Em suma, o pai-trocinador, o horizonte de uma sociedade fraterna, horizontalizada, sem pai. (...) Aqui vivemos a utopia de uma educação sem adultos, onde as crianças gozam como querem. A educação utópica dos anos 80 defende que, na verdade, os pais e professores estariam na mesma condição que as crianças: não são eles que detêm a autoridade, que ditam as regras, que ensinam. Os adultos estão lá para aprender com as crianças. Se os alunos não querem assistir aulas, devemos perguntar o que querem fazer [assim como coagi-las a "combinar" o conjunto das regras que todos deverão - imaginariamente - seguir]. Esse modelo de instituição dá lugar a todo tipo de entraves que vemos atualmente na crise generalizada em que se encontram pais e professores na tarefa educacional: com pais e professores sem autoridade, as crianças não podem mais confiar aos adultos a tarefa da transmissão, tendo que procurar, sozinhas, "onde se encontram os tesouros e qual seu valor" "170 (Idem, ibidem, p. 128129, acréscimo nosso).

$3^{\circ}$. O pai simbólico:

O pai como puro significante - ou as instituições baseadas neste modelo de Lei simbólica - buscariam na organização de uma estrutura vazia - sem sujeitos e sem possibilidade de gozo - uma organização puramente significante. Aqui, ninguém goza, pois não existem sujeitos. Pai e filho, e professor e aluno, ocupam um lugar simbólico dentro de uma estrutura que funciona por si só, que os antecede e os ultrapassa. A burocracia representa o tipo e funcionamento dessas instituições: os alunos são números, os professores também. Quando falta um professor, não há problemas maiores: substituímos este professor por outro, e retomamos a matéria no ponto parado. A estrutura faria, por si só, a função de interdição necessária à prática educativa (Idem, ibidem, p. 128-129).

${ }^{170}$ ARENDT, Hanna (1954). Entre o passado e o futuro. São Paulo: Perspectiva, 2000. 
Aqui não podemos não deixar de lembrar da nova modalidade educacional que instâncias do poder público, não só em nível nacional, tentam ampliar e justificar como outro fazer ideal, a famigerada "educação" a distância ${ }^{171}$, levada a cabo de maneira não presencial, mas pelos recursos informáticos na mediação entre aquele que é apresentado pelo sistema como "professor", e aqueles outros que se apresentam como "alunos", também ao sistema, pois sequer arriscaríamos dizer, aqui, que se mantém a dupla-dinâmica educador-educando, pois não estamos certos de que, nesse registro à distância - de corpos e enunciação - , a educação (ou a enunciação) ainda possa funcionar e marcar subjetivamente o psiquismo de ambos os agentes, a não ser no sentido de sulcar ainda mais os traços por onde já trilham suas vidas esses sujeitos, o que não seria propriamente uma contribuição educ(a)tiva ao psiquismo do educando, embora garanta-lhes o tanto de certificados que conseguiu conquistar para ofertar ao mercado de trabalho. Tal qual naquela pedagogia utópica clássica, em que a aprendizagem se restringe a um processo meramente cognitivo, nos parece que, no ensino a distância, se sobra algum lugar para as versões do gozo, certamente será para aquele do discurso capitalista, em que estão em jogo não propriamente um educando e um educador, mas consumidores e agentes do capital.

$4^{\circ}$. O pai - ou educador - real da identificação:

O pai [ou educador] real não é o pai [ou educador] ideal. O pai real possibilita o enodamento dos três registros: o não do pai totêmico, a estrutura do pai simbólico, e o gozo do pai real. Os três registros estão enodados, sempre estiveram, e somente através de uma versão possível de gozo é que o não imaginário e o não simbólico podem fazer função. É através desta posição particular que o pai - ou o educador - assume, quando reivindica sua parcela de gozo, quando mostra como ele goza, que ele interdita e transmite, ao mesmo tempo, e pode fazer o "não" ter função.

Para exemplificar esta posição, daremos um pequeno exemplo:

A pequena Laura, de 5 anos, havia comido um iogurte após o jantar. Mas ela queria outro. E recebeu seu segundo iogurte. Mas ela queria um terceiro. Foi aí que o educador que estava com ela disse "não" ao terceiro iogurte. Como - ou por que - dizer não a uma crianaça? Podemos pensá-lo, neste exemplo, de difentes maneiras:

- O pai autoritário usaria seu poder: "Eu decido e acabou, eu mando e não tem discussão!", ou até "Eu não dou porque TODOS os iogurtes são meus, porque só eu mando, só eu decido, só eu como, só eu gozo!".

- O pai benevolente daria quantos iogurtes Laura quisesse comer, mesmo com o risco de ela passar mal depois. Provavelmente ele não se responsabilizaria por nada, dizendo: "Foi ela quem quis".

\footnotetext{
171 Sobre o ensino a distância, ver a dissertação de Ricardo Dias Sacco, também orientada pelo Prof.
} Lajonquière, intitulada $O$ ensino a distância e a educação: o corpo e a imagem professoral, 2010, FEUSP. 
- O pai simbólico se basearia nas leis do Outro: “eu não dou, não, porque há uma lei na instituição: cada um poderá comer um único iogurte após as refeições, o Outro-diretor foi quem decidiu, Lei simbólica à qual estamos todos submetidos e barrados.".

- O pai real diria não ao terceiro iogurte, "porque EU vou comer, é o MEU iogurte. Você já comeu os seus, este é MEU”. O não aqui inclui as posições imaginária e simbólica, e interdita algo de seu gozo, ao colocar em evidência algo do gozo do educador.

Nem o primeiro "não", nem o segundo funcionam, se o terceiro não enodá-los [e haver ainda um resto, um real, no meio de tudo, que é o pequeno a]. No caso de Laura, o educador realmente não deu o iogurte porque era [mesmo] o iogurte dele, porque ele não havia comido ainda, e porque ele queria [mesmo] comê-lo. Nesse momento ela parou de insistir, parou de gritar desesperadamente, parou de chorar. Sua angústia pôde ser apaziguada e ela ficou tranquila, olhando o educador comer, dizendo: "Esse é o iogurte do Pedro, a Laura já comeu o dela" (idem, ibidem, p. 130-131, acréscimos e formatação nossos).

Eis agora explicado aquela père-version que citamos anteriormente, quando nos detivemos na função da mãe e vimos que um pai deveria estar père-versamente orientado de modo a fazer de uma mulher o objeto $a$, ou seja, motivo de gozo, père-version ${ }^{172}$ capaz de substituir - repetimos - a perversão na mulher de gozar com o(s) filho(s).

$\mathrm{Na}$ época do real, Lacan desenvolve a função do pai em torno de um pai vivo, dentro de um gozo possível, a père-version. Esta parte da teoria enuncia que somente quando o pai reclama sua parte de gozo é que ele executa a função de interdição e de transmissão. Fechando o nó-borromeano, entendemos, enfim, que os três registros são sincrônicos [e não diacrônicos, apesar da teoria mostrar assim], e a função imaginária, simbólica e real do pai estiveram

\footnotetext{
172 (...) Eu disse bem, uma mulher não é uma mãe. Na constelação familiar, a mãe não é um objeto, é um significante. Ora, o lado feminino implica, bem ao contrário, um não todo. E este não todo concerne àquele que sustenta a função paterna, que ele o saiba ou não, o importante sendo que ele tenha se aventurado a frequentar esse não todo que ressoa especificamente como o que causa ordinariamente seu desejo. Esta relação que caracteriza o pai na relação de gozo que o une à mulher que ele conquistou para nela fazer filhos, Lacan a nomeia de dois modos: ou ele a nomeia père-version - é um jogo de palavra entre a versão do pai e a perversão que caracteriza a sexualidade masculina - ou ele fala da função de sintoma, uma mulher com sintoma do pai, ou seja, como representando seu modo de gozo irredutível e particular. "Para quem é saturado pelo falo, que é uma mulher?" - pergunta-nos Lacan - e ele nos responde: é um sintoma [sinthome]". Isso deve ser escutado no sentido em que o sintoma representa a parte de gozo particular e irredutível de cada um, aquilo que resiste até o limite à decifração pelo sentido. É evidente que Lacan sublinha que o sujeito se sente, por sua vez, embaraçado por este gozo, mas, que ele também o retém, não aspira desembaraçar-se dele. Para um homem, fazer de uma mulher um objeto que cause perversamente seu desejo, é constitui-la como sintoma. É em 1975 que Lacan diz isso e nesse mesmo ano ele definiu o sintoma como uma função no sentido matemático do termo. (...) Qual é o modelo para a função do sintoma? É algo bastante inesperado. Neste texto, Lacan nos adverte: "Vocês não vão acreditar nos seus ouvidos" (LACAN, Séminaire RSI, aula de 21/01/1975). É o pai. É como se houvesse uma conexão entre a função paterna e a função do sintoma. É isso que Lacan dirá sem rodeios em Genebra: o sintoma da criança é a expressão do tipo de pai e do tipo de mãe que ela tem. Dito de outra maneira, o modelo da função é dado pela relação entre pai e mãe (...) e para sermos mais exatos, seria preciso dizer a relação paimulher (Bernard Nominé. Palestra realizada na PUC de São Paulo, em 30/09/2005. In: STYLUS: revista de psicanálise, n. 15, novembro de 2007, p. 49-50. Rio de Janeiro: Associação Fóruns do Campo Lacaniano. Acréscimo nosso).
} 
enodadas, para permitirem efetivamente a função que cabe ao pai (MENA, 2004, p. 131-132, acréscimo nosso).

Ou seja, se uma educação funciona, segundo o autor, é porque , na figura do educador, os três registros estão enodados o que torna possível a esse agente, assim, passar também uma versão de seu gozo a filhos ou educandos - sua père-version, ou seja, a maneira pela qual ele, educador, também goza. E então acrescenta:

Nas escolas, devemos tentar ajudar o professor na mesma tarefa, a de lembrar porque ele está ali, de onde veio, com qual intuito, por qual gozo. O professor de matemática é professor de matemática por algum motivo, e podemos supor - para além da falta de escolha no mercado de trabalho - que é o gozo que responde a esse motivo. Ele identifica alguma forma de gozo possível com a sua escolha, e é essa versão de gozo do professor que faz os alunos respeitarem sua autoridade, e que também faz os alunos aprenderem (Idem, ibidem, p. 133).

Mena finaliza suas conclusões afirmando que a busca pelo "não", em nome de uma suposta autoridade perdida, acabou perdendo o sentido, sendo substituída pelo que achou como "gozo possível do Outro barrado", pois o que importa em termos de autoridade não é exatamente o "não", embora ele seja necessário, mas principalmente a maneira como eles, pai ou educador, gozam inseridos numa filiação simbólica que sustente esse gozo possível, de forma que só assim o "não" e a autoridade possam ter algum efeito educativo, estruturante, de filiação, de aprender, de acesso, de interdição e de transmissão.

Sendo assim, retomamos a questão da renúncia ao ato educativo, aberta por Lajonquière em Infância e Ilusão... para averiguarmos esse "gozo inserido numa filiação simbólica" para, finalmente, chegarmos, ao Nome-(im)próprio como o outro extremo do pendular educativo.

\subsubsection{Do fazer-se herdeiro de um dever de ser ao extremo do Nome- (im)próprio}

Reiteradas vezes Lajonquière vem alertando que a educação dos tempos atuais comete erros graves, embora não se dê conta disso, por ser um discurso fechado, obturado em suas certezas tecnocientíficas, subtraindo do educador a possibilidade de falar em nome próprio. A sintomática insistência em "falar $d a$ criança", em detrimento de "falar com a criança", seria 
um desses erros, tomar esses seres em processo de subjetivação como objetos de suas elucubrações desenvolvimentistas e naturalistas.

\begin{abstract}
A sutil agudeza de Françoise Dolto já nos alertara para o fato de que as expressões "falar da criança" e "falar com a criança" não são equivalentes. $\mathrm{O}$ falar das necessidades e interesses da criança é uma fala especialista. Os especialistas creem saber, graças a elucubrações científicas de ocasião, sobre as necessidades e interesses "da criança" ou de uma criança genérica. Em nome desse ser genérico, falam de A-Criança a outros, ao Outro. Quando dirigem a palavra a uma criança o fazem inevitavelmente em nome desse saber sem nome próprio, o saber dA-Criança. Portanto, os especialistas não falam com uma criança singular com nome e sobrenome. O "falar com a criança" está em função do reconhecimento, por parte do velho, da própria implicação subjetiva em uma educação, quer dizer, de como é perlaborado aquele estrangeiro ao "si mesmo adulto" [o infantil] que o (des)encontro com o pequeno ser realimenta (LAJONQUIÈRE, 2010, p. 215, acréscimo).
\end{abstract}

Entretanto, este não é o único erro grave em que incorre a educação dos moldes corriqueiros atuais, afirma o autor. O paradigma desenvolvimentista é reacionário (cf. idem,ibidem, p. 83), ultraconservador, na medida em que, tal qual um colonizador ou conquistador, impõe ao ser "menor", ou seja, ao indivíduo supostamente ainda nãodesenvolvido, um ponto ótimo a chegar, estipulado, obviamente, por ele que já atingiu o desenvolvimento ideal. Isto faz o educador utilizar, então, a própria imagem especular e exigir que o educando se focalize nela e não saia dali, como a nós parece ter ocorrido com a educação de Laura Bridgman, pelos relatos que obtivemos, embora, no entender da própria Sullivan, pudesse ter ocorrido de forma diferente. Interessante lembrarmos como ela, no início dos trabalhos com Helen, ao dar-se conta do que mostrava ser capaz a menina, não se permitia predizer o ponto máximo a que chegariam naquela educação, pois ela mesma sentia em si uma falta de preparo, uma inconsistência de conhecimentos, que a fazia corar, por não estar à altura do que pressentia que a menina pudesse vir a lhe pedir - demandar. Sabendo da biografia das duas, ficamos a pensar se Anne poderia sequer ter um pressentimento de que, alguns anos depois, estaria viajando o mundo em companhia daquela "sujeita", contando suas histórias e colaborando para que novas formas de cuidado, educação e trabalho fossem disponibilizados aos cegos, surdos, mudos de então. O que ecoa até hoje. Sullivan com certeza fez uso de uma imagem especular em relação a Helen, para o movimento de alienação, de identificação, mas permitiu a ambas não se fixarem ali. Sullivan era uma mulher que, de tempos em tempos, para o desconforto de Keller, jogava suas certezas ao ar, o que devia ser um enigma para Keller, mas também uma versão de gozo para aquela mulher irlandesa. Isso fazia parte do estilo que permitia Anne pendular. Se bom, ou mau, adequado ou não, não vem ao caso. Real. Custoso, provavelmente, muito mais a ela mesma, do que à educanda, que ao 
contrário, em vez de ser "traumatizada" por essas esquisitices da educadora - excentricidades -, pôde beneficiar-se delas, enlaçada pelo pequeno $a$, afinal de contas, por que Anne Sullivan fazia isso????

Essa emergência de real no estilo de Sullivan, a propósito, permite-nos apontar outro erro descrito por Lajonquière em relação à estrutura paradigmática educativa do desenvolvimento ligado ao horror que provoca a emergência do real, geralmente creditada às deficiências do educando, essas que a psicopedagogia tenta, a qualquer custo, integrar à ordem do simbólico, para justificar a lida para com ela.

(...) o adulto quer vir sempre a conhecer o que se passa "na criança". Então ilude-se com a possibilidade de conhecer suas necessidades para poder-lhes dar justa e necessária satisfação. O "adulto" faria, assim, genuína e certa relação com ela, caso contrário, sem conhecê-las, questiona-se: como se poderia educá-las? (...) No entanto, não é dessa forma que a educação de uma criança se desdobra, dizemos. Há educação quando o velho toma como metáfora o desencontro no real com esse pequeno ser no mundo, e, sem muito o saber, faz ex/isitir sentidos não previamente dados "na criança". Esses sentidos injetados pela educação fazem a diferença. (...) a educação precipita numa pura letra sem sentido na carne infantil e, assim, imprime uma e outra vez uma diferença de origem a se desdobrar - o desejo - que causa por sua vez a conquista de um lugar de enunciação em nome próprio no discurso (Idem, ibidem, p. 187).

De modo que educar não pode ser, segundo o autor, nem reduplicar o educando à imagem e semelhança de um ideal suposto - como tentou Itard com Victor - , nem tampouco pretender a loucura de fazê-lo - como um tal Dr. Daniel Gottlieb Moritz Schereber levou a cabo com seus filhos. O que a psicanálise nos alertar, afirma o autor, é de como uma educação pode vir a se tornar de difícil acontecimento, quando houver a impossibilidade (e perguntamos, ou a impotência?) de um velho/educador desdobrar o desencontro no real com a criança/educando (cf. Idem, ibidem, p. 189), isto é, o encontro com o retorno do infantil.

Uma educação só pode acontecer se, no (des)encontro com a criança, os adultos se permitem deparar-se com o retorno da (im)própria estranheza infantil de si mesmos, que tem suas raízes na falta de proporção ou diferença sexual (Idem, ibidem, p. 215).

O problema é que, para isso precipitar-se, para este desdobrar metafórico ocorrer, o educador deve autorizar-se a falar, vez em quando, em nome próprio, e não apenas ficar repetindo as estratégias ofertadas pelo conhecimento científico, proferindo ideias, palavras gastas, vazias, insossas, desprovidas de um desejo em causa, pois só aquelas que levam a marcadas de um desejo, de um gozo, acabam encontrando maneiras de equacionar a 
diferença imposta pelo real da desproporção sexual e geracional entre sujeitos, como vimos com o pai real.

Portanto, não se metaforiza resto algum falando do educando, mas somente com o educando. Manter-se falando dos educandos, paradoxalmente, equivale a manter-se num posicionamento infantil, enquanto educador, porque numa posição que se faz de "adulta" por fazer uso de teorias científicas, mas que na verdade assim procede para proteger-se da emergência do real infantil, ou seja, para denegar a castração, pois da emergência do real no campo educativo o psico-pedagogo-ortodoxo nada quer saber que não há saber, porque se se aventurar a fazê-lo, terá que mudar o registro e passar a falar em nome próprio, portanto aceitando inconscientemente a castração - e seus respectivos atos falhos - abrindo mão do discurso universitário, sempre tão exato, correto, assertivo e seguro, porém não-pregnante.

Neste sentido:

Ser adulto é paradoxalmente não Ser. "Está adulto" aquele que não pode não lançar-se à impossibilidade de falar em seu próprio nome - quer dizer, no nome im/próprio do desejo que o habita e faz falta. Essa posição implica que tanto aquela criança que foi para os outros, como também aquela criança que não foi, mas era esperada, sejam objeto de recalcamento psíquico (Idem, ibidem, p. 210-211, grifo nosso).

Mas o que seria esse falar em nome próprio? Por exemplo, imaginemos um professor de português, Prof. João Tibeiro, que quando se põe a discorrer sobre Gregório de Matos e o Barroco, para em seguida voltar-se a outros desconhecidos, Claudio Manuel da Costa e o Arcadismo, a uma turma de Ensino Médio, sem perceber, traz no olhar e no sorriso um brilho que nos seja estranhamente familiar, e que, ao mesmo tempo nos intriga, porque não sabemos como alguém pode achar tamanha graça em determinado assunto. Quando isso acontece, estará João Tibeiro a professar seus conhecimentos em nome mesmo desse João, filho de Sr. e Sra. Tibeiro? Sim e não.

Sim, porque se esse senhor conseguiu inventar uma história de vida para si, onde o ensino da língua teve seu lugar entre outros - afinal João não é só professor, mas talvez pai, avô, síndico, primo, marido, jogador de bilhar, cantor, vizinho, etc - , foi porque foi constituído como uma subjetividade a partir de um casal parental, Sr. e Sra. Tibeiro. Entretanto, não será por conta dessa filiação simbólica que irá professar ou metatransmitir o gozo que atua junto ao ensino da literatura ou da língua portuguesa como um todo, em diversos de seus aspectos que puder abordá-la - linguístico, semiótico, histórico, geográfico, gramatical, entre outros. Aqui retomamos a argumentação de Lajonquière para dizer que esse nome próprio, de onde o Prof. João Tibeiro encontra assento em seu endereçamento aos 
sujeitos, foi conseguido via locomotivas e vagões, ou seja, veio sendo enlaçado através de um encadeamento de outros sujeitos que, antes dele, se voltaram, como ele, aos estudos da língua portuguesa, isto que confere à palavra de João Tibeiro, "uma marca de pertinência ou um traço identificatório (...) que em si mesma carrega uma dose de existência, ou seja, uma cota de saber fazer com a vida" (LAJONQUIÈRE, 1997, p. 33) e que, dali em diante, se configurou a partir de uma outra filiação simbólica, agora fora do seio familiar. Ou seja, João só ensi(g)na - e o $(\mathrm{g})$ aqui é o brilho estranho no olhar e no sorriso - , porque recebeu esse ensi(g)namento de um outro, que recebeu de um outro e assim por atrás. Não por diante. Diante, não há nada. Há os alunos, que poderão ou não engatar nesse vagão, o que João só saberá, talvez, a posteriori. Então, de onde vem a autorização para João Tibeiro falar em nome próprio, já que pode muito bem nunca ter sido um ex-pert em metodologia do ensino de português, nem tampouco nas estratégias das psicopedagogias de plantão? Sua autorização virá, defende Lajonquière, da dívida simbólica que todo aprendiz contrai com seus mestres, por terem adquirido deles um saber para a sua existência, ou seja, para a invenção de um savoir-vivre (cf. Idem, ibidem, p. 30). Quiçá de ex-istência? No caso de João, ex-istência contraída, em parte, com aqueles que lhe ensi(g)naram sobre o Barroco, Gregório de Matos, o Arcadismo, Claudio Manuel da Costa e tantos outros, autores e períodos.

Ele se autoriza, devidamente, invocando a potestade graciosa própria da tradição dos mestres honrados. Mais ainda, é essa invocação - e o reconhecimento da dívida nela embutida - que outorga caráter verdadeiramente simbólico ao transmitido. O transmitido em lugar de ser um simples índice do amor magistral, é um signo sui generis - um significante tanto da dívida do mestre pelo empréstimo parcial do qual goza, quando do desejo em causa no ato educativo (Idem, ibidem, p. 31).

Por isso, então, decidimos designar o outro extremo do pendular como Nome(im)próprio. Primeiro, porque todo nome próprio, com nome e sobrenome, faz referência a uma história e pré-história familiar, em que se inscrevem uma série de mandatos especulares, de eu ideal.

Os nomes que os pais colocam no filho fazem também alusão a uma série de ideais ou conjunto quase sempre heteróclito de mandatos existenciais. De fato, todo nome constuma encerrar deveres do tipo: vir a ser um a mais como o avô na série dos seres honrados ou vir a ser como um homem que, como o pai, renuciou à sua própria mãe. Porque na educação não só se trata de veicular ideais de ordem simbólica, senão também de ideais imaginários (idem, ibidem, p. 32).

Na mesma direção indica Erik Porge: 
O nome próprio - no qual se deve incluir o prenome (...) - divide o sujeito, pois quando o sujeito quer agarrar sua identidade através do seu nome próprio, ele aí encontra uma determinação exterior que o ultrapassa e que faz obstáculo à auto-apreensão de sua identidade. O nome e o prenome que o identificam lhe vêm de seus pais e a tomada da sua identificação, por este meio, confrontao com o desejo do Outro. (PORGE, 1998, p.16).

Por conseguinte, Joao Tibeiro que foi infans, depois criança, tendo crescido e passado por todas as etapas da vida escolar, supõe-se que, ao escolher o mundo das letras para mergulhar com afinco - já que assim verdadeiramente o fez, caso contrário não haveria o tal brilho no olhar - , tenha seguido as pistas de seu desejo que lhe pulsava em verdades, em libido, mas não necessariamente, aquele contabilizado nas prospectivas de seus pais. João escolheu, assim, em nome im/próprio ${ }^{173}$, porque próprio ao seu desejo, embora, talvez, não tão apropriado ao desejo de seus progenitores. Fazendo isso, João Tibeiro, antes mesmo de se fazer e nomear professor, começou por tomar como seu o que herdou da metáfora paterna $^{174}$, encontrando na vida e na cultura um jeito, socialmente valorizado, para gozar e acrescentar algo de seu, isso que fará parte de seu estilo.

E por que escolhemos o Nome-(im)próprio para o outro extremo pendular, já que falar em nome próprio indica uma certa independência dos mandatos ideais científicos? Porque levado ao extremo seria admitir que o educador poderia tudo, até mais-de-gozar, já que o faria em Nome-(im)próprio, o que também não procede, porque assim, seria dar livre arbítrio ao desejo, como fez, por exemplo, Dr. Daniel Gottlieb Schreber, este que se tornou célebre

(...) como se sabe, por suas obras de anatomia, fisiologia, higiene, cultura física e pedagogia. A sua autoridade foi enorme enquanto viveu (e por largo tempo depois de sua morte). Era escutado por educadores, médicos e pais. Deve-se-lhe a elaboração de regras de vida fundadas numa disciplina impecável. [Entretanto] Quando se conhece a atenção minuciosa e o zelo com que o Dr. D. G. M. Schereber pôs em prática, no seu próprio lar, os princípios educativos de onde extraiu, subsequentemente, uma teoria que alcançou notoriedade, cumpre formular a seguinte pergunta: por que acidente o filho de um pai tão excepcional pôde vir a ser psicótico [enquanto o outro se suicidou] (MANNONI, 1977, p. 24, acréscimos nossos)?

\footnotetext{
${ }^{173}$ Como vimos na citação da página 226, Lajonquière utilizou essa grafia em Figuras do infantil... (2010, p. 210), onde acrescentou , ainda, a seguinte nota de rodapé: "Impróprio como não privativo, mas também como algo não próprio para o consumo por estar turvo. Sobre o chamado nome próprio recai de fato uma espécie de copropriedade: mais de um de nós recebemos um "mesmo" nome e, portanto, não é tão privativo assim, como se pensa. Por outro lado, o nome que recebemos está sujo, vem melado pelo desejo em causa no ato mesmo da nomeação. Dar um nome a alguém não deixa de ser uma violência simbólica".

${ }^{174}$ Em Totem e tabu (1913), Freud cita uma passagem de Goethe, em O Fausto, que diz: "Aquilo que herdaste de teus pais, conquista-o para fazê-lo teu", embora outras traduções do alemão possam ser sugeridas: "pegue sua herança e faça dela algo seu" ou "aquilo que herdaste, conquista, para torná-lo verdadeiramente seu"
} 
Sem dúvida, podemos dizer que esse homem, Schreber, o pai, tenha feito tudo o que fez em nome próprio $^{175}$, já que desfrutava de um lastro no discurso social a validar o poder de sua palavra, entretanto também teria feito tudo aquilo em Nome-(im)próprio, pois devia gozar muito ao ver seus filhos, sob o cuidado das babás, seguirem a risca os princípios educativos rigidamente traçados por ele, entre os quais, aquele de aprender a "a arte da renúncia", que segundo Mannoni, é

(...)fazer com que a criança sinta o desejo de alguma coisa, para se lhe recusar em seguida aquilo que ela não deixará de pedir. A ama, com a criança em seu colo, é assim convidada a comer e beber com o único propósito de opor em seguida uma recusa ao pedido oral da criança. Cumpre suprimir o desejo para deixar somente subsistir os automatismos (a fome a horas certas). O Dr. Schreber conta como despediu imediatamente uma ama por ter infringido a regra ao dar a seu filho um pedaço de pêra fora de horas. O caso foi tão falado em Leipzig, que ele nunca mais teve problemas com as amas seguintes. (Idem, ibidem, p. 29, acréscimo nosso).

D. G. M. Schreber encarnava em sua pessoa, de acordo com o que nos conta Mannoni, um saber científico dotado de poder de cura, para o qual era preciso pacientes capazes de submissão total, de abandono radical do seu corpo e do seu ser. Se esse terrorismo pedagógico participava, por um lado, na situação paranoica da época, o que reconhecemos como um discurso social, é certo que encontrou em Schreber alguém para sistematizá-lo e atribuir-lhe uma autoria, o que nos parece ter sido feito em nome próprio, ou melhor, em Nome-(im)próprio.

(...) o mesmo zelo posto na elaboração de um corpo de doutrina médicopedagógica permitiu-lhe construir uma armadura de proteção contra a dúvida (e o risco de descompensação psicótica). O seu filho Daniel Paul Schreber só pôde elaborar no delírio uma nova construção do universo, construção essa que representava, assim, de uma certa forma, a outra face da doutrina paternal (Idem, ibidem, p. 28).

\footnotetext{
${ }^{175}$ Nome próprio: Ao designar teu corpo e o lugar dele na filiação, o nome próprio se singulariza por ser um puro significante. Como significante, ele te segue por toda parte no mundo, pois o nome próprio não se presta à tradução, subsiste a todas as línguas, "até em Babel". Nem por isso, contudo, ele "revela" tua identidade. (...) Para Lacan, o nome próprio é de certo modo o significante "sigla", que demonstra que o sujeito é servo da linguagem e, mais precisamente, da letra. (...) A partir das pesquisas de Gardiner, Lacan sustentará a ideia de que o que constitui o nome próprio não é tanto o fonema, mas a letra. O nome próprio esboça mesmo "a instância da letra no inconsciente", pois a realização de um ideal tautológico é impossível; por um lado, a letra não recobre o fonema e, por outro, dizer-te por exemplo como eu me chamo não te dirá rigorosamente nada sobre mim. Por essa razão, em D’un discours qui ne serait pas du semblant Lacan dirá que o "nome convida a falar". (...) Por volta de 1975 (R.S.I.), Lacan aproximou o nome próprio do sintoma. O neurótico obstrui o real-impossívelimpensável com seu sintoma; ora, nessa condição, o sintoma é algo de "verdadeiro". Nomear é igualmente produzir algo de "verdadeiro", mas, nesse mesmo movimento, ao se distinguir do real, o sujeito se afasta dele, deixando o real em seu lugar. Assim, com a nomeação, "o bom tolo" cria um nome ali onde se opera a falha do real, o que quer dizer que, em suma, nomear é sublimar, agir como letra, abrir passagem para si numa via obstruída (Mireille Andrès, in KAUFMANN, 1996, p. 372-373).
} 
Ou seja, doente, ou não, Schreber não cedeu de seu desejo, isto que, às vezes, é preciso fazer para se viver em sociedade sem abusar da ética, nem da paciência alheia, principalmente quando estamos no campo da educação, lidando com sujeitos em processo de constituição subjetiva, este que é um posicionamento nosso. Se Schreber estivesse vivo, ainda, para ver o suicídio de um filho e o surto psicótico do outro talvez, pudesse ter se responsabilizado por algo, o que a nós parece ser uma hipótese bastante improvável. Portanto, em Nome-(im)-próprio, não se pode fazer tudo aquilo que se deseja, pelo menos não em função da educação de um outro, a menos que se faça desse outro, o educando, seu objeto de prazer para mais-de-gozar, seu fetiche ${ }^{176}$, porém isso não haverá como cumprir, jamais, o pendular da função educativa como estamos aqui tentanto representar. Porque ali, não haveria pêndulo, mas uma única e potente seta, partindo do “educador" em direção certeira à alma do "educando" - imagem que talvez equilibre com a boca do crocodilo.

Nesse tempo meu pai e minha mãe estavam caracterizados: um homem sério, de testa larga, uma das mais belas testas que já vi, dentes fortes, queixo rijo, fala tremenda; uma senhora enfezada, agressiva, ranzinza, sempre a mexer-se, bossas na cabeça mal protegida por um cabelinho ralo, boca má, olhos maus que em momentos de cólera se inflamavam com um brilho de loucura. Esses dois entes difíceis ajustavam-se. Na harmonia conjugal a voz dele perdia a violência, tomava inflexões estranhas, balbuciava carícias decentes. Ela se amaciava, arredondava as arestas, afrouxava os dedos que nos batiam no cocuruto, dobrados, e tinham dureza de martelos. Qualquer futilidade, porém, ranger de dobradiça ou choro de criança, lhe restituía o azedume e a inquietação. (...)

Achava-me empoleirado no balcão, abrindo caixas e pacotes, examinando as miudezas da prateleira. Meu pai, de bom humor, apontava-me objetos singulares e explicava o préstimo deles.

Demorei a atenção nuns cadernos de capa enfeitada (...). Tive a ideia infeliz de abriu um desses folhetos, percorri as página amarelas de papel ordinário. Meu pai tentou avivar-me a curiosidade valorizando com energia as linhas mal impressas, falhadas, antipáticas. Afirmou que as pessoas familiarizadas com elas dispunham de armas terríveis. Isto me pareceu absurdo: os traços insignificantes não tinham feição perigosa de armas. Ouvi os louvores, incrédulo.

Aí meu pai me perguntou se eu não desejava inteirar-me daquelas maravilhas, tornar-me um sujeito sabido como padre João Inácio e o advogado Bento Américo. Respondi que não. (...) Meu pai insistiu em considerar esses dois homens como padrões e relacionou-os com as cartilhas da prateleira. Largou pela segunda vez a interrogação pérfida. Não me sentia propenso a adivinhar os sinais pretos do papel amarelo?

\footnotetext{
${ }^{176}$ Fetichismo: Organização particular do desejo sexual, ou libido, na qual a satisfação completa não pode ser atingida sem a presença e o uso de um objeto determinado, o fetiche, que a psicanálise reconhece como substituto do pênis que falta à mãe, ou ainda como significante fálico. (...) Como explicar o fetichismo e sua importância na sexualidade humana? (...) De fato, é da questão da castração que é preciso partir, aqui ou, mais precisamente, do "terror da castração", ativado pela percepção da ausência do pênis na mulher, na mãe (Roland Chemama, in CHEMAMA ; VANDERMERSCH, 2007, p. 150).
} 
Foi assim que se exprimiu o Tentador, humanizado, naquela manhã funesta. A consulta me surpreendeu. Em geral não indagavam se qualquer coisa era do meu agrado: havia obrigações, e tinha de submeter-me. A liberdade que me ofereciam de repente, o direito de optar, insinuou-me vaga desconfiança. Que estaria para acontecer? Mas a pergunta risonha levou-me a adotar procedimento oposto à minha tendência. Receei mostrar-me descortês e obtuso, recair na sujeição habitual. Deixei-me persuadir, sem nenhum entusiasmo, esperando que os garranchos do papel me dessem as qualidades necessárias para livrar-me de pequenos deveres e pequenos castigos. Decidime.

E a aprendizagem começou ali mesmo. (...)

Meu pai não tinha vocação para o ensino, mas quis meter-me o alfabeto na cabeça. Resisti, ele teimou - e o resultado foi um desastre. Cedo revelou impaciência e assustou-me. Atirava rápido meia dúzia de letras, ia jogar solo. À tarde pegava um côvado, levava-me para a sala de visitas - e a lição era tempestuosa. Se não visse o côvado, eu ainda poderia dizer qualquer coisa. Vendo-o, calava-me. Um pedaço de madeira, negro, pesado, da largura de quatro dedos. (...)

Afinal, meu pai desesperou de instruir-me, revelou tristeza por haver gerado um maluco e deixou-me. Respirei, meti-me na soletração, guiado por Mocinha. (...)

Certamente meu pai usara um horrível embuste naquela maldita manhã, inculcando-me a excelência do papel impresso. Eu não lia direito, mas, arfando penosamente, conseguia mastigar os conceitos sisudos: "A preguiça é a chave da pobreza - Quem não ouve conselhos raras vezes acerta - Fala pouco e bem: ter-te-ão por alguém."

Esse Terteão para mim era um homem, e não pude saber que fazia ele na página final da carta. (...)

- Mocinha, quem é o Terteão?

Mocinha estranhou a pergunta. Não havia pensado que Terteão fosse homem. Talvez fosse. "Fala pouco e bem: ter-te-ão por alguém."

- Mocinha, que quer dizer isso?

Mocinha confessou honestamente que não conhecia Terteão. E eu fiquei triste, remoendo a promessa de meu pai, aguardando novas decepções (RAMOS, 2008 p.109-114). 
Saiba (Arnaldo Antunes)

Saiba: todo mundo foi neném Einstein, Freud e Platão também Hitler, Bush e Saddam Hussein Quem tem grana e quem não tem

Saiba: todo mundo teve infância Maomé já foi criança Arquimedes, Buda, Galileu e também você e eu

Saiba: todo mundo teve medo Mesmo que seja segredo Nietzsche e Simone de Beauvoir Fernandinho Beira-Mar

Saiba: todo mundo vai morrer Presidente, general ou rei Anglo-saxão ou muçulmano Todo e qualquer ser humano

Saiba: todo mundo teve pai Quem já foi e quem ainda vai Lao-Tsé, Moisés, Ramsés, Pelé Gandhi, Mike Tyson, Salomé

Saiba: todo mundo teve mãe Índios, africanos e alemães Nero, Che Guevara, Pinochet e também eu e você 


\section{Considerações finais}

Início dos anos 80. G. devia ter no máximo $1,55 \mathrm{~m}$ de altura e 35 anos, apesar de trazer no rosto vincos de mais avançada idade. A pele não era clara - parecia levar o tom da bile. Usava barba e bigodes negros, cerrados, pelos quais deslizava os dedos, pentrando em auto-agrado, habitual.

Corpo atlético, desfilava na frente do quadro negro andando em ritmos alternantes. Às vezes, sem esperarmos, girava, feito bailarino espanhol, acho que para acordar a gente, fazendo firula. Uma estratégia, talvez.

Usava salto alto, em botas de cowboy, pretas, brilhantes de tão limpas. Davam-lhe pelo menos $10 \mathrm{~cm}$ a mais na altura, dentro das calças jeans e camisetas apertadas que faziam mostrar, além dos músculos do peito e dos braços, alguns excessos de barriga recolhida.

Era altivo, levava o peito emplumado, pomposo como era, feito galinho garnizé solto no terreiro, bravo, a se espalhar. Eu achava graça. Parecia mesmo um sátiro. Entretanto, a pequena estatura redimensionava por algo levado em dentro, transpirado no jeito meticuloso e inteligente de suas aulas, quando mesclava rigor e sarcasmo às explicações da biologia.

Exigia respeito, sequer os meninos do fundo abusavam de sua paciência - nervoso, colerificava.

Tinha sempre um sorriso meio sacana no rosto, que escorria, também, pelas tangentes do olhar. "Deve gostar de sexo", imaginava.

Era tão exigente nas provas que, caso conseguisse atingir a nota mínima, a mim que nunca fui excelente estudante, já estava de bom tamanho.

Além de "cientista" e professor, era também autor de livros de grande tiragem. Gostava de escrever, além de ser exímio desenhista. Suas lousas explicativas, de tão belas, chegavam a esbarrar nas dobras da perfeição. Ficávamos fascinados. Por que caprichar tanto assim, se ele mesmo sabia que, ao virar a porta, seriam apagadas? Eram como bordados coloridos, feito presente preparado na hora, artesanal, mas que, de repente sumiam, feito pó, em giz. Que coisa!

O que tanto terei aprendido com ele senão propriamente "sua" amada Biologia, nem "suas" formas de desenhar ou escrever, a me capturar, mas uma tal imagem que não se apaga e permanece viva, feito referencial que pulsa, pulsa, pulsa, quando ponho-me a reminiscer...?

Lembremos de um professor cuja palavra foi pregnante. A memória há de trazer algum para, com ele, ilustrarmos os efeitos de uma enunciação... Com ela, conseguimos entender por que o que se apre(e)nde com os outros nem sempre é aquilo, nem naquela medida em que se supunha, ou se imaginava, estar sendo realmente "aprendido" e “ensinado", quiçá transmitido... Nas botas de cowboy, da lousa em bordados, no afagar da barba aparada, para além da complexa citologia, por exemplo, talvez estivesse sendo ofertado algo do cuidado de si e do desejo de saber...

A história do sujeito desenvolve-se numa série mais ou menos típica de identificações ideais que representam os mais puros dentre os fenômenos 
psíquicos por eles revelarem essencialmente a função da imago. E não concebemos o Eu senão como um sistema central dessas formações, sistema que é preciso compreender, à semelhança delas, na estrutura imaginária e em seu valor libidinal (LACAN (1946), 1998, p. 179).

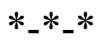

A pedagogia não é uma religião, nem a escola uma igreja. Carteiras da escola não são lugares para postarmos as crianças e fazê-las rezar em nossa companhia o terço da pedagogia não-diretiva, do escola-novismo, da antroposofia, do sócio-construtivismo, seja qual for o método assertivo da vez, na tentativa de evitar o que se configura como uma ferida narcísica no campo de uma educação, especificamente, a impossibilidade de controlar tanto o ensinar, quanto o aprender. Tal como ocorre com o obsessivo, os rituais metodológicos não nos protegem da emergência do inesperado, nem do retorno do recalcado, mas aludem a alguém que se faz de morto, de modo que o método mais novo-do-novo já nasce predisposto ao cheiro do mofo, a algo tanto quanto putrefato. Acatar um método de ensino, de jeito ou outro, indica resignar-se enquanto educador, seja a uma diretriz, a uma norma ou regra, como ato de renúncia à autoria para não falar em nome próprio, muito menos em Nome-(im)próprio, consentindo no emperramento do pendular.

Para nós, a questão do educar não está na implantação de recursos ideais da didática ou no desvelamento dos funcionametos psicológicos do indivíduo, como pregam tecnocratas, mas no endereçamento de uma palavra plena e por isso educ(a)tiva por parte do educador e na (in)consequente tomada desta pelo educando, ou seja, no assento do discurso.

Sendo assim, o currículo explícito que uma escola ou um educador professam não pode ser apresentado como um enunciado apócrifo, tal qual palavra jogada ao outro a partir de um sujeito que se faz de morto, que segue esforçando-se por repetir e executar as mesmas ladainhas proferidas pela ortodoxia, por onde é possível encontrar recursos para evitar a castração que anima o sujeito, seguindo na tentativa de fazer assepsia no ensinar e no aprender, ambos inexoravelmente ligados aos pruridos produzidos nos processos de identificação, transferência e contra-transferência, como também aqueles produzidos pela equilibração majorante no assentamento temporário de novas representações lançadas pela palavra do educador, provocando conflito cognitivo no educando, tal qual ensinou-nos Piaget, de modo que aprender e ensinar só podem mesmo acontecer entre avanços e retrocessos, tropeços e assaltos, sucessos e fracassos, nada assépticos, mas melecados de real. 
Nem religião, nem resignação, educar é para nós estratégia, dispositivo de subjetivação pela qual se transmite (ou não) o desejo por manter-se vivo, postergando o único acontecimento inevitável do ser vivente, ponto de basta por excelência sempre possível de ser transposto a qualquer hora e lugar pelo sopro de um crime, de uma fatalidade, de um colapso físico, de um ato falho, para o qual muitas vezes o sujeito se inclina, sem no entanto aperceber-se. Pulsão de morte, sempreviva.

- Educar tem a ver com o cuidado de si, eis outra dimensão da função do educador: metatransmitir um saber viver e um saber cuidar de si mesmo e do mundo, como ensinou Foucault... e o tal professor de biologia...

Ainda que a padronização metodológica na evitação obsessiva do sujeito da enunciação não consiga atingir $100 \%$ de seus objetivos - porque o professor não é ainda uma máquina, nem está por completo posto à distância - , acaba por trabalhar e favorecer a obliteração das marcas de estilo, cerceando singularidades de ambos os lados, seja do professor, seja do aluno, dificultando nada menos que o pendular, já que este se sustenta pelo estilo, assentado no objeto causa de desejo. Todo o aparato didático-pedagógico ideal, ao invés de trazer soluções para o exato ensinar, acaba ceifando a transmissão de marcas simbólicas, subjetivantes, colaborando para que se torne insulso muito daquilo que, por ventura, poderia ser ensinado, aprendido e metatransmitido com mais sabor e pregnância, na via dupla, moebiana, entre educador e educando. Querendo ou não, o educador, enquanto sujeito da enunciação, estabelece compromisso com a verdade, esta que é sempre uma verdade sexual, sinalizando ao aparelho psíquico de quem se endereça algo muito mais instigante e legítimo do que o levado a cabo pela tecnocracia escolar representante dos enunciados da ciência psicológica ou cognitiva. Eis aí a reedição do trígono edipiano, aquele do educar-enodar-enlaçar de que falávamos no começo. Um tal funcionamento fechado, baseado em assertivas pedagógicas, apostamos, não só não contribui para fazer circular a impossibilidade do educar, como ao contrário, dificulta esta que já é, em sim, uma atividade bastante complexa e arriscada de ser encarnada, subtraindo-lhe o lastro para o pendular.

- Então voltamos a perguntar, aos pedagogos que estão aí, não poderíamos tentar outro movimento, inventar um happening, dançar mesmo um iê-iê-iêe? Muitos dizem que não, que a Pedagogia continuará sendo normativa, metodológica, assertiva. Ortodoxa. Entretanto, a Pedagogia não são os pedagogos, assim, queremos aqui proferir e responder que sim. Porque o savoir-faire diz que sim... e a microfisica do poder também... 
No campo da educação, aquilo que está em questão é a conquista por parte da criança de um lugar que the possibilite o usufruto do desejo (LAJONQUIÈRE, 1999, p. 165).

Neste contexto, cabe afirmar que conhecimento, saber, desejo e dívida simbólica se pressupõem e articulam em toda educação. Mais ainda, cabe concluir que educar não é nada mais que o corriqueiro pôr em ato de um processo de filiação ou sujeição a ideais, desejos, sistemas epistêmicos e dívidas (Idem, ibidem, p. 173).

Nem tudo que escrevo resulta numa realização, resulta numa tentativa. O que também é puro prazer. Pois nem em tudo eu quero pegar.

Às vezes, quero apenas tocar.

Depois o que toco às vezes floresce

e os outros podem pegar com as duas mãos (Clarice Lispector).

O saber sobre o objeto $a$ seria, então, a ciência da psicanálise? Essa é precisamente a fórmula que se trata de evitar, uma vez que esse objeto $a$ deve ser inserido, já o sabemos, na divisão do sujeito pela qual se estrutura, muito especialmente, o campo psicanalítico. [No entanto] (...) esse objeto $a$ não é tranquilo, ou melhor, caberia dizer que ele não deixa vocês tranquilos? - e menos ainda aos que mais lidam com ele: os psicanalistas, que portanto, seriam aqueles que, de maneira eletiva, eu tentaria esclarecer através de meu discurso. (LACAN, 1998, p. 878-879, acréscimo nosso).

Até outubro de 1889, achei melhor não submeter Helen a lições preestabelecidas e metódicas. Nos dois primeiros anos da vida intelectual, ela foi como uma criança atirada num mundo onde tudo era novo e complicado, tornando-se impossível submetê-la a um curso regular. Além do mais, era tal a atividade indagadora da criança que seria esmagar-lhe o espírito não satisfazer sua incessante curiosidade só para ensiná-la por métodos préfixados. Ensinei-lhe as coisas precisamente no momento em que ela manifestava desejo de aprendê-las. (Anne Sullivan, in KELLER, 2001, p. 232, trecho do relatório de 1891).

Para enfrentar isso que incomoda e escapa bem no centro da encenação do "adulto" frente às crianças, a pedagogia vem tentando a ortodoxia de buscar a educação ideal pela adoção adequada dos métodos de ensino. Contudo, se é fato que a demanda educativa enviada pelo professor chegue mesmo muitas vezes em endereços diferentes do sobrescrito ao aluno - erroneamente tomado como objeto modelável - , não significa o fim do mundo, nem razão para desistirmos de continuar tentando a educação desses sujeitos em crescimento, menos ainda de tentar fazer algo mais interessante e saboroso - já que apostamos na possibilidade de uma pedagogia não-ortodoxa. Significa apenas que, talvez, já seja hora de abrir mão da obsessão ilusória de ser possível atingir a educação ideal, como se fosse um maquinário pelo qual se enfiam os educandos para que, depois de um tempo, saiam 
formatados e conformados à imagem e semelhança do narcisismo "adulto" que assim os desejou.

A despeito de magnas pretensões, métodos ultracientíficos e instrumentos tecnológicos de ponta - tal qual o novo pupilo do Estado, o econômico e virtual ensino à distância - , talvez não seja mesmo possível ensinar tudo a todos, num mesmo tempo e lugar, através das mesmas palavras, corpos e telas de computadores. E nem por isso seremos, também, menos ou mais felizes do que vimos sendo até hoje. Então, nossa contribuição, como alertava que fizéssemos a Prof. Denise Catani (FEUSP), foi dada, acreditamos, através de um protomodelo criado para ilustrar o que entendemos ser uma oscilação relativamente constante do fazer educativo encarnado por um sujeito - portanto por um falta-a-ser - , posicionado na função de educador em uma estrutura que não é a familiar, embora também subjetivante quando se mostra capaz de reeditar algo que, na primeira educação, foi levado a diante por um pai e uma mãe, em funções paterna e materna.

Para ilustrar o que em nosso entender é um pendular entre dois lugares que se opõe dentro da estrutura de uma educação, propusemos o pêndulo de Foucault como analogia para o funcionamento da palavra em ato do educador, suportada pelo estilo, assentado no objeto causa de desejo - o pequeno $a$-, a incidir sobre dois vetores, o desejo-do-pedagogo, espécie de reeditor do que foi um dia a função materna, e o Nome-(im)próprio, derivado no Nome-doPai, da teoria de Jacques Lacan, para ocupar o extremo que, inicialmente, havíamos imaginado como sendo o da funçao paterna. Assim, para pendular entre Cila e Caribde, ou seja, ente a permissão e a contenção, o sim e o não, o supor e o exigir, estariam nesses extremos ambas acepções da etimologia de educar, educatio (levar para dentro, nutrir) e eductio (fazer sair, fazer limite).

Os escritos e a história de Sullivan e Keller foram oferecidos, justamente, para exemplificar esse funcionamento pendular, despregado do padrão metodológico e psicopedagógico hegemônico, o que nos permitiu constatar a diferença entre o falar com o educando e o falar do educando, além dos efeitos subjetivantes que essa torção discursiva pode vir a provocar na vida de algúem. Ou melhor, de "alguéns", porque fez diferença não só na vida da menina, mas também na vida da educadora, motivo pelo qual não utilizamos um pêndulo simples, para a protomodelagem, mas o pêndulo de Foucault, que trabalha com dois referenciais, ao invés de um. Semelhante ao que ocorre na fita de Moebius, o ato educativo causa efeitos tanto ao educando, quanto ao educador, uma vez que pode estar sustentado pelo estilo de endereçamento da palavra educadora e não pelo discurso universitário e/ou capitalista. Eis, também, o motivo de termos trazido a teoria dos discursos de Lacan - 
repetimos - não para vertê-la sobre um estudo de caso, quando esta não foi nossa intenção, mas para mostrar que uma educação pode funcionar como a que Sullivan ofereceu a Helen e a ela mesma, em outro registro, diverso do que costuma proferir a educação ideal, configurada como um modo discursivo hegemônico do fazer psicopedagógico, onde o espaço para uma autoria educativa, inclusive no âmbito mais "pedagógico" , fica muito restrito.

Anne falava com Helen, e não com o Outro da ciência, de forma que não esperava da menina nenhum tipo de retificação de um saber científico, próprio ao diálogo surdo e corriqueiro dos dias atuais, em que o educador, embora se disponha a "dialogar" com o educando, entra na dinâminca educativa como se tivesse as orelhas e olhos vendados, suturados para toda e qualquer devolutiva ou produção subjetiva que não esteja em consonância com o leque de possibilidades legítimas que o Outro científico lhe ditou, como fez Jean Itard a Victor de Aveyron. Victor não falava, mas se tentasse, ou se tentou, teria ou teve como "interlocutor" não um pai, nem uma mãe, nem um educador em função pendular, mas um protótipo de educador sujeito à ciência e não ao desejo, porque o desejo de Itard era reiterar o não-desejo, ofertando um único espelho, sobre o qual Victor deveria colar, para não mais descolar daquela que deveria ter aceitado com sua imagem ideal.

Propor a imagem pendular para a função do educador é tentar demonstrar que não se pode, no educar, ficar paralisado, nem em um extremo, o da alienação, nem no outro, da separação.

Desejo da mãe reeditado em desejo-de-pedagogo. Investimento endereçado como fosse espécie de provocação, de demanda pelo olhar, pelo escutar, pelo evocar. Desejo-depedagogo metatransmitido pelo poder de perfuração da palavra que penetra, que recorta mas não esgarça - em nome do objetos da cultura, a matéria-prima do educador, o que por sua vez pode mostrar-se como um atributo de um Nome-(im) próprio. O enlace que se tenta em nome da Álgebra, das regras gramaticais, do uso culto das línguas, dos conhecimentos históricos, geográficos, das belezas e curiosidades da física, química, filosofia, enfim...se faz inicialmente também por uma palavra de desejo, um voto, uma crença. O que quero de você, aluno? Que você aprenda! Que experimente o prazer do raciocínio lógico, da alquimia da escrita, do imaginário da leitura, do escorregadio da letra, do perigo da vida, porque como diz Riobaldo em meio ao grande sertão, “viver é perigoso!"... Investimento de mestre que, pelo desejo em causa, incita para a mobilização de forças do estudante no sentido de que este procure e encontre meios para vivenciar, suportar e até mesmo sentir prazer pelo caminho às vezes tortuoso do aprender, aberto também ao gozo da angústia causada pelo confilito 
cognitivo, pela resistência à realização necessária do conjunto de trabalhos, vez ou outra árduos, estafantes, exigidos pelos professores aos alunos, estes fulanos que, constantemente, se veem apreensivos entre as marchas e contramarchas dos entendimentos, das incompreensões e, principalmente, do mal-estar quando reconhece em si a ignorância, a dificuldade de concentração, a falta de paciência, a incapacidade momentânea ou cíclica de não fechar as contas do aprender, de não suportar o erro, a castração que, sem saber, o locomove, como se a sua cabeça fosse um vaso já cheio, sem espaço para uma gota a mais de conhecimento, sequer. Desejo não mais de mãe, mas de professor ou educador que procura levar a andar e a falar aquele que ainda claudica, locomovendo ao caminhar para o aprender, como fazia o pedagogo grego, embora não como mestre.

No lado oposto ao extremo do desejo-do-pedagogo, o Nome-(im)próprio do mestre, que se exerce para o efeito de corte, de basta, de contenção pulsional, de alteridade, mas também de gozo, quando aparece estampado nele, via agalma, a insígnia pela dívida contraída a um processo subjetivante de filiação simbólica, do qual extrai sua autoridade, assim como de seu dever de ser mestre. Ensina-se por dever, aprende-se por amor, sintetiza Lajonquière (1999), querendo dizer que o educando aprende por amor de transferência, ou seja, via identificação, enquanto o educador ensina para pagar uma dívida impagável - porque simbólica - por ter se sujeitado, ou melhor, se filiado, em algum momento de sua vida, a certo ideal de cultura metatransmitido por uma linhagem de mestres, a quem deve não somente uma parcela do conhecimento adquirido - este que os mestres não deixaram desaparecer, passando a diante - , como também e, principalmente, um savoir-vivre, ou seja, um saber-fazer (e gozar!) com a vida desse falta-a-ser encarnado num corpo, com nome e sobrenome.

Assim, na função de educador, o "falta-a-ser" encarnado que se propõe a educar um outro, diante de seus educandos, deverá oscilar entre a oferta e a retirada, o aceite e a recusa, na suposição de que o sujeito - quando estiver disposto - fará o que ainda não conseguiu fazer e, concomitantemente, encontrar meios para restringir o gozo do educando, quando este insistir no prazer que lhe dá a regressão ao infantil, reeditando ali, fora do seio familiar, as "tonterias" que não cabem mais ficar.

Em suma, pressupondo que os dois extremos de educ $(a)$ r se configurem como uma boca voraz, de educatio, e uma adaga, de eductio, retomamos a fala de Cícero - educere gladium e vagina - para acrescentar e defender, como exercício próprio da função do educador, o implicar-se, via perlaboração, no evitamento de se fixar seja num extremo ou no outro, à mestria de aprender a embainhar e desembainhar a palavra, pendulando. 
- A propósito III: vagão: em deslizamentos, vaga, onda, cada uma das elevações de grande porte formadas nos mares, rios, lagos etc. pelos movimentos de vento, marés,

água que se agita e se eleva, grande quantidade de pessoas, animais, veículos ou coisas em movimento, conjunto de embarcações ou aeronaves lançadas em curto intervalo de tempo para missão específica, lugar, espaço que não se encontra ocupado e pode vir a sê-lo, falta, ausência, carência, ocasião própria,estar ou ficar vago, vazio, vagar, sobrar, restar (tempo), ocupar-se de, entregar-se a, deixar vago ou proclamar como tal, vagar, falta de pressa; lentidão, vagareza, tempo desocupado, ócio, folga, ensejo, oportunidade, andar sem rumo certo, perambular, vaguear, movimentar-se ao sabor do vento, das vagas, do acaso, ser de conhecimento público; espalhar-se, correr, percorrer sem destino certo (um lugar, um país, o mundo), que não está preenchido ou ocupado ou que está prestes a vagar; vacante, tempo durante o qual permanece não preenchido um cargo, um emprego; vacância, vacatura, vagatura...

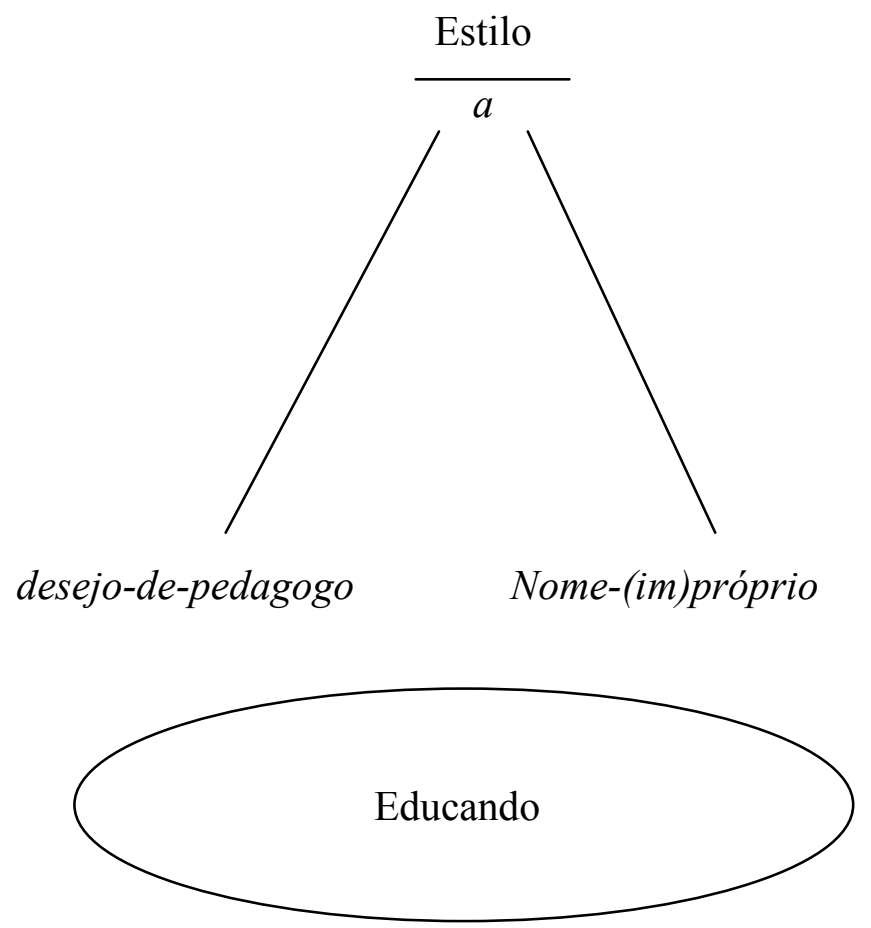


Tudo o que não invento é falso.

Manoel de Barros 


\section{REFERÊNCIAS}

ALBERTI, S. (2000) O discurso do capitalista no mal estar da cultura. (Apresentação de Trabalho/Congresso). Disponível em: http://www.scribd.com/doc/19133239/Sonia-Alberti-O-Discurso-Do-Capitalist-A-e-o-MalEstar-Na-Cultura . Acesso em 25/02/2010.

ALEMAN, Jorge ; LARRIERA, Sergio. Lacan: Heidegger. Buenos Aires: Ediciones Del Cifrado, 1998.

ANDRADE, Sérgio C. Courbet, retratos de um devorador de imagens. Disponível em : http://static.publico.clix.pt/docs/cultura/courbet_devoradorDeImagens.pdf, acesso em $15 / 02 / 2011$.

ANTELO, Estanislao. Identidade e Pedagogia. Deslocamento e conceitos impuros. Do "unfinished animal" ao sujeito como nome da liberdade. Carrossel, Salvador: Cartograf, v. 3, n. 3 e 4, p. 37-47, nov. 1999.

AZANHA, José Mário Pires. Uma ideia de Pesquisa Educacional. São Paulo: Edusp, 1990.

BANKS-LEITE, Luci ; GALVÃo, Izabel (Orgs.) A educação de um selvagem: as experiências pedagógicas de Jean Itard. São Paulo: Cortez, 2000.

BARROS, Manoel de. A infância. São Paulo: Editora Planeta do Brasil, 2006.

. Memórias Inventadas: A segunda infância. São Paulo: Editora Planeta do Brasil, 2006.

. Memórias Inventadas: A terceira infância. São Paulo: Editora Planeta do Brasil, 2008.

. Memórias Inventadas: Poesia completa. São Paulo: Leya, 2010.

BERNARDINO, Leda Mariza Fischer (org.). O que a psicanálise pode ensinar sobre a criança, sujeito em constituição. São Paulo: Escuta, 2006.

BORGES, Emílio; BRAGA, João Pedro. O efeito de Coriolis: de pêndulos a moléculas. Química Nova, São Paulo, v. 33, n. 6, 2010 . Disponível em : $<$ http://www.scielo.br/scielo.php?script=sci_arttext\&pid=S0100-

$40422010000600036 \& \operatorname{lng}=$ en\&nrm=iso $>$. Acesso em 13 fev. 2011.

BORGES, Sônia. O quebra-cabeça: a alfabetização depois de Lacan. Goiânia: Ed. da Universidade Católica de Goiás, 2006.

BRAGA, Luciana Pereira. "Dos traumas ao mundo misterioso de Thomas: o acompanhamento de um processo de inclusão em creche". In: COLLI, Fernando Anthero Galvão (org). Travessias inclusão escolar: a experiência do grupo ponte Pré-escola Terapêutica Lugar de Vida. São Paulo: Casa do Psicólogo, 2005. 
CALLIGARIS, Contardo et alli. Educa-se uma criança? Porto Alegre: Artes e Ofícios, 1994.

CAMARGo, Ana Carolina Corrêa Soares de. Educar: uma questão metodológica? Proposições psicanalíticas sobre o ensinar e o aprender. Petrópolis: Vozes, 2006.

CAMBI, Franco. História da Pedagogia. Tradução Álvaro Lorencini. São Paulo: Editora da UNESP, 1999.

CANDIDO, Antonio. O direito à literatura. In: Vários Escritos. 4. ed., São Paulo: Duas Cidades; Rio de Janeiro: Ouro sobre Azul, 2004. p. 169-192.

1972. . A literatura e a formação do homem. Ciência e Cultura. 24 (9): 803-809, set,

CARVALHO, José Sérgio F. de. Matrizes conceituais do Discurso Educacional: uma reflexão preliminar. In: Construtivismo: uma pedagogia esquecida da escola. - Porto Alegre: Artmed Editora, 2001.

CHEMANA, Roland ; VANDERMERSCH, Bernard. Dicionário de Psicanálise. São Leopoldo: Unisinos, 2007.

CHÈMOUNI, J., in Dicionário enciclopédico de psicanálise: o legado de Freud e Lacan. Rio de Janeiro: Zahar Ed., 1996.

CIFALI, Mireille ; IMBERT, Francis. Freud e a pedagogia. São Paulo: Edições Loyola, 1999.

COELHO, Eduardo Prado. Estruturalismo, antologia de textos teóricos. Lisboa: Portugalia, 1968.

CORR̂̂A, Roberto Alvim. Dicionário escolar francês-português português-francês. Brasília: MEC, Departamento Nacional de Educação, 1961.

COUTINHO JORGE, M.A. Discurso e liame social: apontamentos sobre a teoria lacaniana dos quatro discursos. In: Revisa Humanidades, n. 49, Brasília: UnB, p.40-53, 2003.

CUNHA, Antônio Geraldo da. Dicionário etimológico Nova Fronteira da Língua Portuguesa. Rio de Janeiro: Nova Fronteira, 1982.

DIATKINE, Gilbert. Jacques Lacan. Porto Alegre: Artes Médicas Sul, 1999.

DOR, Joel. O pai e sua função em psicanálise. Rio de Janeiro: Jorge Zahar Editor, 1991.

DUNKER, Christian Ingo Lenz. A questão do sujeito: construção, constituição e formação. In: Uma Psicologia que se Interroga. São Paulo. Edican, 2002, v.1, p. 19-82.

Discurso e Narrativa na Construção do Saber Sexual. In: Educação,

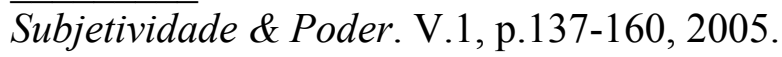


Introdução à Psicanálise Lacaniana, conceitos e contextos. (Apresentação de Trabalho/Simpósio). Texto cedido pelo autor. Original: Style is the Man Himself. The Letter Lacanian, v. 31, p. 120-143, 2006. / The Man is the Style Himself: contexts and concepts of Lacanian Psychoanalysis. 2006.

. Estratégia e Constituição da Clínica Psicanalítica. Tese de pós-doutorado, IPUSP: São Paulo, 2007.

ELIA, Luciano. O conceito de Sujeito. Rio de Janeiro: Jorge Zahar, 2007.

ELIAS, Norbert. O processo civilizador. Rio de Janeiro: Jorge Zahar Editora, 1994. 2v.

FARIAS, Cynthia Nunes de Freitas ; LIMA, Glaucineia Gomes de. A relação mãe criança: esboço de um percurso na teoria psicanalítica. Estilos da clinica. , vol.9, n.16 [citado 201102-07], p. 12-27, 2004. Disponível em:

$<$ http://www.revistasusp.sibi.usp.br/scielo.php?script=sci_arttext\&pid=S1415-

71282004000100002\&lng=pt\&nrm=iso $>$. ISSN 1415-7128. Acesso 6/01/2011.

FERREIRA, A. G. Dicionário de Latim-Português. Porto Editora: Porto, sd.

FERRETTI, Maria Cecília Galletti. O Infantil: Lacan e a modernidade. Petrópolis, RJ: Vozes, 2004.

FILLOUX, Jean Claude. Psicanálise e educação. São Paulo: Expressão e Arte, 2002.

FLEIG, Mário. A Tese do Declínio da Imago Social do Pai e o Deslocamento da Autoridade In: A Psicanálise, a Educação e os Impasses da Subjetivação no Mundo Moderno. São Paulo: Lugar de Vida e LEPSI, 2000.

FRAGELLI, Ilana Katz Z. ; PETRI, Renata. A transmissão da falta, a partir da leitura do seminário IV de Lacan. In: Estilos da Clínica, Vol. IX, no. 17, p.118-127. São Paulo: USPIP, 2004.

FRANCO, Maria Amélia Santoro. Pedagogia como ciência da educação. São Paulo: Cortez, 2008.

FREUD, Sigmund. Obras Psicológicas completas de Sigmund Freud: Edição Standard brasileira. Rio de Janeiro: Imago, 1996.

. Algumas Reflexões sobre a Psicologia Escolar. In: Totem e tabu e outros trabalho. RJ: Imago, 1996, v. XIII (1913-1914), p. 243-250.

. O mal-estar na civilização. In: O futuro de uma ilusão, o mal-esta na civilização e outros trabalhos. RJ: Imago, 1996, v. XXI (1927-1931), p. 73-148.

. Novas Conferências Introdutórias sobre Psicanálise e outros trabalhos. RJ: Imago, 1996. V. XXII (1932-1936), p. 17-177.

GUSDORF, George. Professores pra quê? Para uma pedagogia da pedagogia. Portugal: Moraes, 1963. 
HANNS, Luiz Alberto. Dicionário comentado do alemão de Freud. Rio de Janeiro: Imago, 1996.

HEGEL, Georg Wilhelm Friedrich . Fenomenologia do espírito. Petrópolis: Vozes, 2003.

HOMERO. Odisseia. Trad. Donaldo Schüler. Porto Alegre: L\&PM, 2007.

HOUAISS, Antônio. Dicionário Houaiss eletrônico da Língua Portuguesa. RJ: Objetiva, 2001. CD-ROM.

IMBERT, Francis. A questão da ética no campo educativo. Petrópolis, RJ: Vozes, 2001.

JULIEN, Philippe. Psicose, perversão, neurose: a leitura de Jacques Lacan. Rio de Janeiro, Companhia de Freud, 2002.

KAMERS, Michele. Do universal da maternagem ao singular da função materna. Dissertação de mestrado, FEUSP, 2005.

KAUFMANN, Pierre. Dicionário enciclopédico de psicanálise: o legado de Freud e Lacan. Rio de Janeiro: Zahar, 1996.

KELLER, Helen. A história de minha vida. São Paulo: Antroposófica: Federação das Escolas Waldorf no Brasil, 2001.

. Minha vida de mulher. Rio de Janeiro: Livraria José Olympio Editora, 1953.

. Lutando contra as trevas: Minha professora Anne Sullivan Macy. Rio de Janeiro: Editora Fundo de Cultura, 1959.

KUPFER, Maria Cristina M. Desejo de saber. Tese de doutorado, Instituto de Psicologia da Universidade de São Paulo, 1990.

. Freud e a Educação: O mestre do impossível. São Paulo: Scipione, 2000.

. Educação para o futuro: psicanálise e educação. São Paulo: Escuta, 2001.

LACAN, Jacques. O Seminário, livro 1: os escritos técnicos de Freud (1953-1954). Rio de Janeiro: Jorge Zahar Editor, 1990.

. (1946) Formulações sobre a causalidade psíquica. In Escritos.

. (1953) O simbólico, o imaginário e o real: conferência de 8 de julho de 1953 na Sociedade Francesa de Psicanálise. Inédito. Tradução de Christian Dunker, oferecida pelo tradutor.

- O Seminário, livro 2: o eu na teoria de Freud e na técnica da psicanálise (19541955). Rio de Janeiro: Jorge Zahar Editor, 1985. 
Editor, 1999.

O Seminário, livro 5: as formações do inconsciente. Rio de Janeiro: Jorge Zahar . (1957 - 8a). De uma questão preliminar a todo tratamento possível da psicose. In:

Escritos. Rio de Janeiro, RJ: Zahar, 1998 (p. 537-90).

2005.

. (1962-1963) O Seminário, livro 10: a angústia. Rio de Janeiro: Jorge Zahar Editor,

(1964) O Seminário, livro 11: os 4 Conceitos Fundamentais da Psicanálise. Rio de

Janeiro: Jorge Zahar Editor, 1990.

. (1966) Escritos. Rio de Janeiro: Jorge Zahar Editor, 1998.

. (1969). Duas notas sobre a criança. Opção Lacaniana. Revista Brasileira

Internacional de Psicanálise. Escola Brasileira de Psicanálise, n 21. Edições Eolia, 5-6.

Zahar, 1991.

. (1969-1970) Seminário, livro 17: o avesso da psicanálise. Rio de Janeiro: Jorge

. (1974) Televisão. In: Outros escritos, Rio de janeiro: Jorge Zahar Editor , 2003.

. (1974-1975). Séminaire, livre 22: RSI. Inédito.

$448-497$.

(2001) O aturdito. In: Outros escritos. Rio de janeiro: Jorge Zahar Editor , 2003, p.

Outros escritos. Rio de janeiro: Jorge Zahar Editor, 2003.

LAJONQUIÈRE, Leandro de. De Piaget a Freud: para uma clínica do aprender. A (psico)pedagogia entre o conhecimento e o saber. Petrópolis: Vozes, 1992a.

- O legado pedagógico de Jean Itard. A Pedagogia: ciência ou arte? In: Educação e Filosofia, vol. 6, n.12, p. 37-51, 1992 b.

. Epistemologia e Psicanálise: o estatuto do sujeito. In Percurso: Revista de Psicanálise, ano VII, No. 13, p. 57-63, 2. Semestre de 1994.

. A criança, "sua" (in)disciplina e a psicanálise. In AQUINO, Julio Groppa (Org). Indisciplina na escola: alternativas teóricas e práticas. São Paulo: Summus, 1996.

. Dos "erros" e em especial daquele de renunciar à educação. In: Estilos da Clínica:

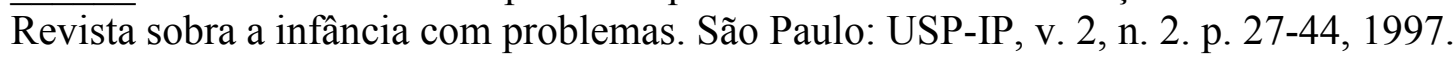

Infância e ilusão (psico)pedagógica : escritos de psicanálise e educação. Petrópolis: Vozes, 1999.

. Figuras do infantil: a psicanálise na vida cotidiana com as crianças. Petrópolis: Vozes: 2010. 
LAPLANCHE, Jean ; PONTALIS, J. B. Vocabulário de psicanálise. Tradução: Pedro Tamen. $4^{\mathrm{a}}$. ed. São Paulo : Martins Fontes, 2001.

LEBRUN, Jean-Pierre. Um mundo sem limite: ensaio para uma clínica psicanalítica do social. Rio de Janeiro: Companhia de Freud, 2004.

LEVIN, Esteban. Clínica e educação com as crianças do outro espelho. Petrópolis, RJ: Vozes, 2005.

LÉVY, Robert. O infantil na psicanálise: o que entendemos por sintoma na criança. Petrópolis, RJ: Vozes, 2008.

LISPECTOR, Clarice. Crônica para jovens: de escrita e vida. Rio de Janeiro: Rocco Jovens Leitores, 2010.

MALERONKA, Camila. Caetano Fraccaroli: arte, reflexão e ensino. Iniciação Científica, Fauusp-Fapesp, 2000. Disponível em :

http://www.usp.br/fau/atelier/Caetano Fraccaroli arte reflexao ensino.pdf . Acesso 9/02/2011.

MANNONI, Maud. Educação Impossível. Rio de Janeiro: Francisco Alves Editora, 1977.

MASOTTA, Oscar. O comprovante da falta. Campinas: Papirus, 1987.

MAURANO, Denise. Um estranho no ninho ou A Psicanálise na Universidade. In: COUTINHO JORGE, Marco Antônio. (Org.). Lacan e a formação do psicanalista. Rio de Janeiro: Contra-capa Livraria, 2007, v. 1, p. 209-227. Disponível em: http://www.semiosfera.eco.ufrj.br/anteriores/semiosfera45/conteudo_exp_dmaurano.htm. Acesso em 27/01/2011.

MELMAN, Charles. A Neurose Obsessiva. Rio de Janeiro: Companhia de Freud, 2004.

MENA, Luis Fernando Belmonte. A função do pai em psicanálise: para que serve a autoridade? (função e deriva na modernidade). Dissertação de mestrado. São Paulo: IPUSP, 2004.

MILLOT, Cathérine. Gide, Genet, Mishima: inteligência da perversão. Trad. Procópio Abreu. Rio de Janeiro: Companhia de Freud, 2004.

MONTEIRO, Elisabete Aparecida. A transferência e a ação educativa. Dissertação de mestrado, FEUSP, 2000.

NASIO, J. D. O Olhar em Psicanálise. Tradução Vera Ribeiro. Rio de Janeiro: Jorge Zahar Editor, 1995.

. Lições sobre os 7 Conceitos Cruciais da Psicanálise. Tradução Vera Ribeiro. Rio de Janeiro: Jorge Zahar Editor, 1997.

NOGUEIRA, Luiz Carlos. O Campo Lacaniano: Desejo e Gozo. Psicologia. São Paulo: USP, v. 10, n. 2, 1999. 
OLIVEIRA, Marta Kohl de. Vygotsky: aprendizado e desenvolvimento: um processo sóciohistórico. São Paulo: Scipione, 1997.

PEREIRA, Marcelo Ricardo. $O$ avesso do modelo: bons professores e a psicanálise. Petrópolis: Vozes, 2003.

. A impostura do mestre. Belo Horizonte: Argvmentvm, 2008.

PEREIRA, Robson de Freitas (org). Sargento Pimenta Forever. Porto Alegre: Libertos, 2007.

PETRI, Renata. Psicanálise e educação no tratamento da psicose infantil: quatro experiências institucionais. São Paulo: Annablume, Fapesp, 2003.

PIAGET, J. The concept of structure. In SCIENTIFIC thought: concepts, methods and procedures. Paris: Unesco, 1972, p. 35-56.

PORGE, Erik. Os nomes do pai em Jacques Lacan: pontuações e problemáticas. Rio de Janeiro: Companhia de Freud, 1998.

QUICHERAT, L. Novíssimo Dicionário Latino-Português. Etimológico, prosódico, histórico, geográfico mitológico, biográfico, etc. Rio de Janeiro e Belo Horizonte: Garnier, 1993.

QUINET, Antônio. Desejo como Poder. Jornal do Brasil, 31/03/2001 . Disponível em:

http://74.125.113.132/search?q=cache:KW2dn3oqk48J:jbonline.terra.com.br/jb/papel/caderno s/ideias/2001/03/30/joride20010330003.html +centro+da+teoria+lacaniana $+\mathrm{h} \% \mathrm{C} 3 \% \mathrm{~A} 1+\mathrm{uma}+$ $\mathrm{cr} \% \mathrm{C} 3 \%$ ADtica + ao + mal-estar + na + sociedade + de + consumo\&cd $=1 \&$ hl $=$ pt-

$\underline{\mathrm{BR} \& \mathrm{ct}=\mathrm{clnk} \& \mathrm{gl}=\mathrm{br}}$. Acesso em 25/02/2010.

- A ciência psiquiátrica nos discursos da contemporaneidade. In: Psicanálise, capitalismo e cotidiano. VIANA, Nildo (Org.). Goiânia: Edições Germinal, 2002.

. O Estilo, o Analista e a Escola. s.d. Disponível em:

http://www.estadosgerais.org/historia/142-o estilo.shtml Acesso em 25/02/2010.

RAMOS, Graciliano. Infância. 39ª . Edição. Rio de Janeiro: Record, 2008.

RINALDI, Doris. Joyce e Lacan: algumas notas sobre escrita e psicanálise. Pulsional revista de psicanálise. 19(188):74-81, dez. 2006.

ROCHA, Zeferino. O amigo, um outro si mesmo: a Philia na metafísica de Platão e na ética de Aristóteles. Psyche (Sao Paulo), São Paulo, v. 10, n. 17, jun. 2006 . Disponível em $<$ http://pepsic.bvsalud.org/scielo.php?script=sci_arttext\&pid=S1415-

$11382006000100005 \& \operatorname{lng}=$ pt\&nrm=iso $>$. Acesso em 23/02/2011.

ROSA, João Guimarães. Manuelzão e Miguilim. In: Corpo de Baile. 11 ${ }^{\mathrm{a}}$. Edição. Rio de Janeiro: Nova Fronteira, 2001. 
ROUDINESCO, Elisabeth; PLON, Michel. Dicionário de psicanálise. Tradução de Vera Ribeiro, Lucy Magalhães. Rio de Janeiro: Jorge Zahar, 1998.

ROUDINESCO, Elisabeth. Jacques Lacan: esboço de uma vida, história de um sistema de pensamento. São Paulo: Companhia das Letras, 2008.

SAFATLE, Vladimir. Lacan. São Paulo: Publifolha, 2007. Col. Folha Explica, 73.

SANTAELLA, Lúcia. O que é semiótica. São Paulo: Brasiliense, 1983. Col. Primeiros Passos.

SANTIAGO, Ana Lydia Bezerra. A inibição intelectual na psicanálise: Melanie Klein, Freud e Lacan. Tese de doutorado, IPUSP, 2000.

SAURET, M.-J. O infantil e a estrutura. São Paulo: EBP, 1998

SAYAO, Luís Fernando. Modelos teóricos em ciência da informação - abstração e método científico. Brasília: Ciência da Informação, v. 30, n. 1, Abril, 2001. Disponível em: $<$ http://www.scielo.br/scielo.php?script $=$ sci_arttext\&pid=S0100$19652001000100010 \& \operatorname{lng}=$ en\&nrm=iso $>$. Acesso em 22 Jan. 2011.

SOLLER, Collete. O que Lacan dizia sobre as mulheres. Rio de Janeiro, Jorge Zahar, 2005.

SOUZA, Francisco Antônio de. Novo dicionário latino-português. $6^{\mathrm{a}}$. edição. Rio de Janeiro: Livraria Francisco Alves, 1934.

TORRINHA, Francisco. Dicionário Latino-Português. $3^{\text {a }}$. edição. Lisboa: Marânus, 1945.

VYGOTSKY, L. S. Pensamento e Linguagem. São Paulo: Martins Fontes, 1991.

. "Aprendizagem e Desenvolvimento Intelectual na Idade Escolar". In: LEONTIEV, Alexis et alli. Psicologia e pedagogia: bases psicológicas da aprendizagem e do desenvolvimento. São Paulo: Centauro, 2005.

ZILIOTTO, Denise Macedo. A posição do sujeito na fala e seus efeitos: uma reflexão sobre os quatro discursos. Psicologia. USP, São Paulo, v. 15, n. 1-2, junho, 2004 . Disponível em: http://www.scielo.br/pdf/pusp/v15n1-2/a21v1512.pdf. Acesso em 23 outubro de 2009. 
ANEXOS 


\section{ANEXO A - Trechos selecionados de "Por que ler a Odisseia?". Tradução de Donaldo Schüler}

A Odisseia nunca deixou de ser lida. Esteve nas mãos de Virgílio, de Camões, de Joyce, de Ezra Pound, de Guimarães Rosa, de Garcia Márquez. Em momentos decisivos, a Odisseia abalou a literatura ocidental. Por que deixaríamos de lê-la agora? Como a Ilíada, a autoria da Odisseia é atribuída a Homero, um autor legendário do século IX A.C.. (...) A Odisseia percorre o caminho contrário ao da Ilíada. (...) Enquanto que o campo de batalha requer, na Ilíada, número limitado de qualidades, situações imprevistas solicitam aqui respostas para as quais não houve preparo. (...) Como não há exércitos inimigos que afastem o herói do objetivo, Homero cria obstáculos de outra ordem. A natureza cuja força encheu de espanto o homem desde sempre, é uma delas. Ela ataca com tempestades, estreitos rochosos, mares desconhecidos, escassez de alimento. Para vencê-la, requer-se inteligência, além de destreza, coragem e força. Sem o amparo de ninguém, Odisseu inventa soluções para todas as dificuldades. Os deuses, que decretaram o seu regresso à pátria, ofereceram recursos imprecisos para realizá-lo . Odisseu é vitorioso por ser quem é. (...)

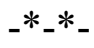

\section{CANTO 12}

(Logo após retornarem do Hades, Odisseu e seus homens prestam homenagem a Circe, deusa feiticeira, que os ensina como se proteger do canto das Sereias, além de alertálos sobre o que viria depois.)

(...) 'Se vencerdes incólumes esse obstáculo [as Sereias], não quero

relatar detalhes do que virá depois. Tu mesmo

deverás decidir qual das direções te convém.

Posso caracterizar-te as duas alternativas.

De um lado, rochas íngremes. Quebram-se ali

os vagalhões de Anfitrite (esposa de Poseidon e, portanto, senhora dos mares) de cenho sombrio (...)

Lá flutuam tábuas de naus, cadáveres de homens, levados pelo sal das ondas, pelo fogo voraz dos 
ventos. Só a uma nau transmarítima foi consentido travessia, a decantada Argo ao voltar de Eetes. Mesmo essa teria sido lançada contra o penedo, não fosse Jasão tão caro a Hera. Mais adiante, erguem-se dois alcantis. A ponta de um penetra no cerúleo mar celeste. Uma nuvem negra o coroa sempre. Não esboroa. Nunca a claridade ilumina o pico, nem no outono, no verão tampouco. Mortal algum o escalaria, nem se manteria no topo. Vinte pés e vinte mãos lhe valeriam bem pouco. Tão lisa é a rocha que parece lavrada. Abre-se no meio da rocha uma caverna sombria, voltada ao Ocidente, para o Érebo. Convém que navegues precisamente nessa direção, iluminado Odisseu. Atirador algum, por robusto que seja, se alvejar a caverna desde a nau bojuda, poderá alcançá-la. Essa é a morada de Cila, a terrível ladradora. Late lá dentro ao jeito de uma cadelinha recém-nascida; trata-se no entretanto, de um monstro devastador, ninguém gostaria de vê-la, nem mesmo um deus. Dotada de doze pés, disformes todos, ostenta seis pescoços exageradamente longos. Cada um acaba numa cabeça assustadora. A bocarra com dentuça tríplice de compactos e sólidos dentes é ninho da morte. Metade do corpo some no fundo do antro, mas a cabeçorras avançam, aterradoras. Explorando o rochedo, caça delfins, lobos marinhos. Abocanha, por vezes, monstros encorpados, desses que Anfitrite produz aos milhares. Nauta nenhum se vangloria de evasão sem prejuízo. De cada navio que passa o monstro arrebata seis marinheiros.

Esse é o preço pago pelos navios de enegrecida proa. Verás, Odisseu, outro escolho, mais raso. Entre um e outro, a distância é pouca. Uma seta a vence. Lá se 
ergue uma figueira robusta de luxuriante folhagem. Ao sopé do rochedo, a água negra desce pela goela de Caribde. Três vezes ao dia, ela a expele para reabsorvê-la fragorosamente depois. Não estejas por lá na sucção. Ninguém te salvaria, nem mesmo o Abala-Terra. Navega, portanto, perto do escolho de Cila sem hesitar. Te é mais vantajoso deplorar o sumiço de seis companheiros do que perder todos.' Reagi assombrado: 'Minha Deusa, estou transtornado. Responde-me com franqueza. Digamos que consiga escapar da devastadora Caribde. Poderia eu atacar a outra quando ela tentasse molestar meus remeiros?' A reposta não demorou e foi certeira: 'Estás louco? Não há nada em tua cabeça além de ações bélicas? Queres sangue? Não recuas nem diante dos deuses, de imortais? Cila não morre. Pertence às calamidades indestrutíveis: é cruel, é assombrosa, é selvagem. Não há solução. Fugir dela é o melhor remédio. Se perderes tempo diante da rocha para te armar, temo por ti. As cabeças de Cila poderiam voltar em número igual para arrebatar mais seis homens teus. Passar por ela é o mais sensato.'

(tradução de Donaldo Schüler) 
ANEXO B - Exemplo de um girador

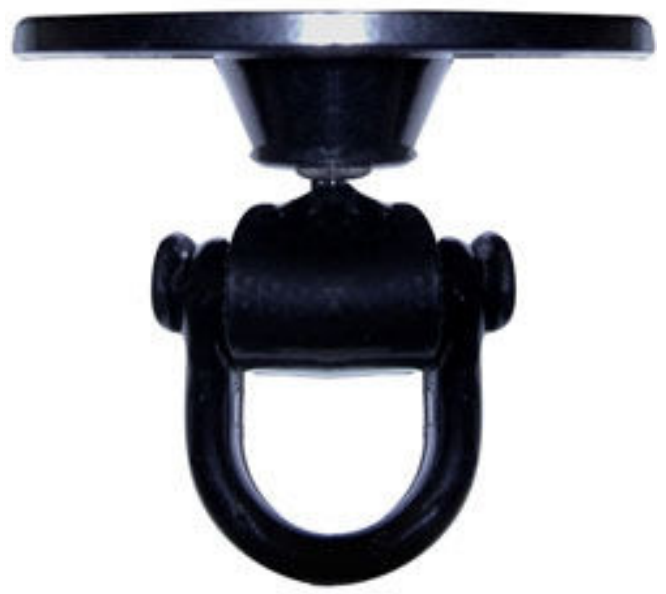

Girador para punching ball.

Fonte: http://www.corpoidealsuplementos.com.br/produtos.asp?desc=girador-p-punchingball-profissional--america\&produtoid=1010 , acesso em 29/01/2011. 
ANEXO C - Anne Sullivan, Helen Keller, John Macy, Chaplin e cachorros
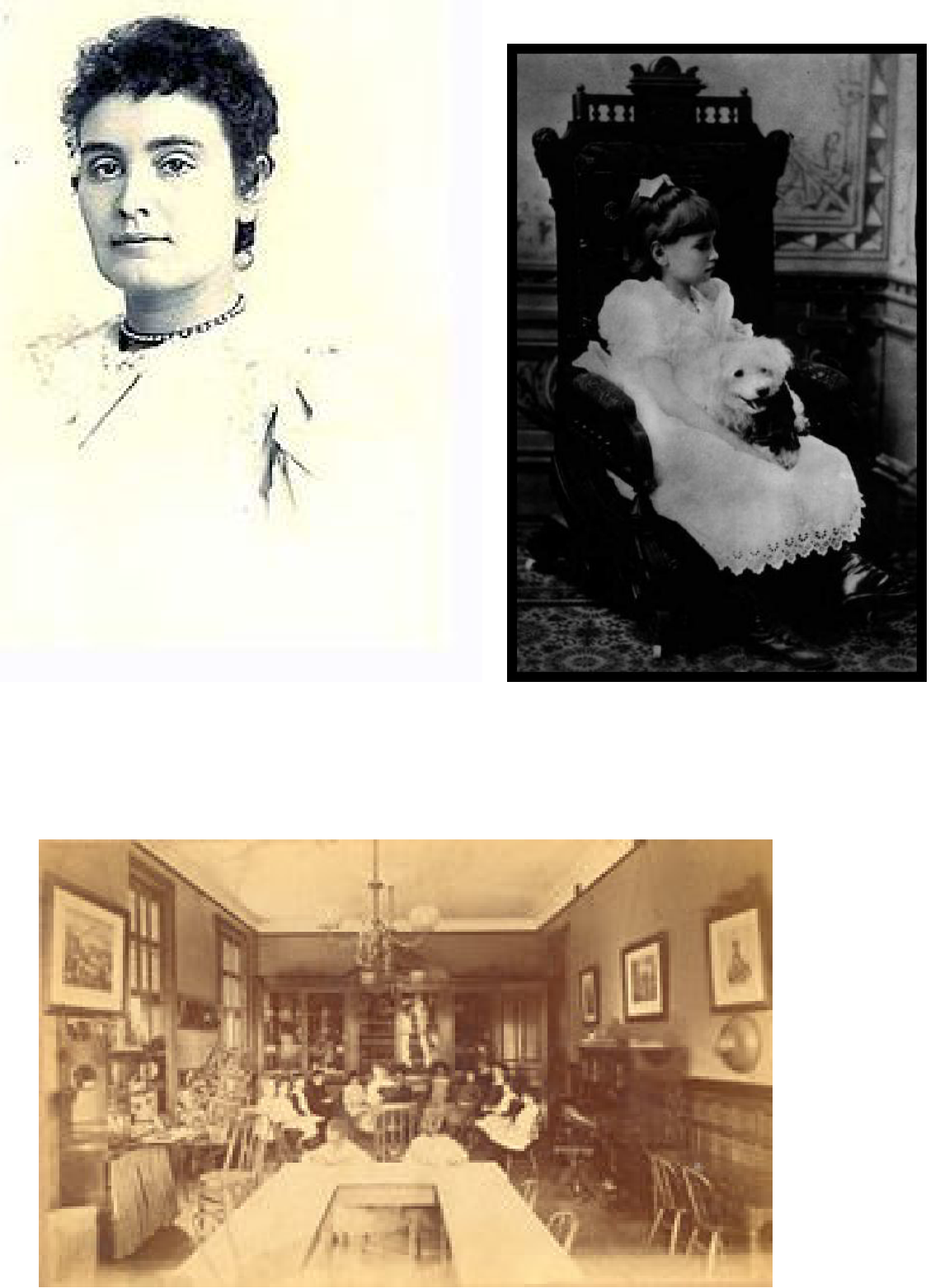

Instituto Perkins 

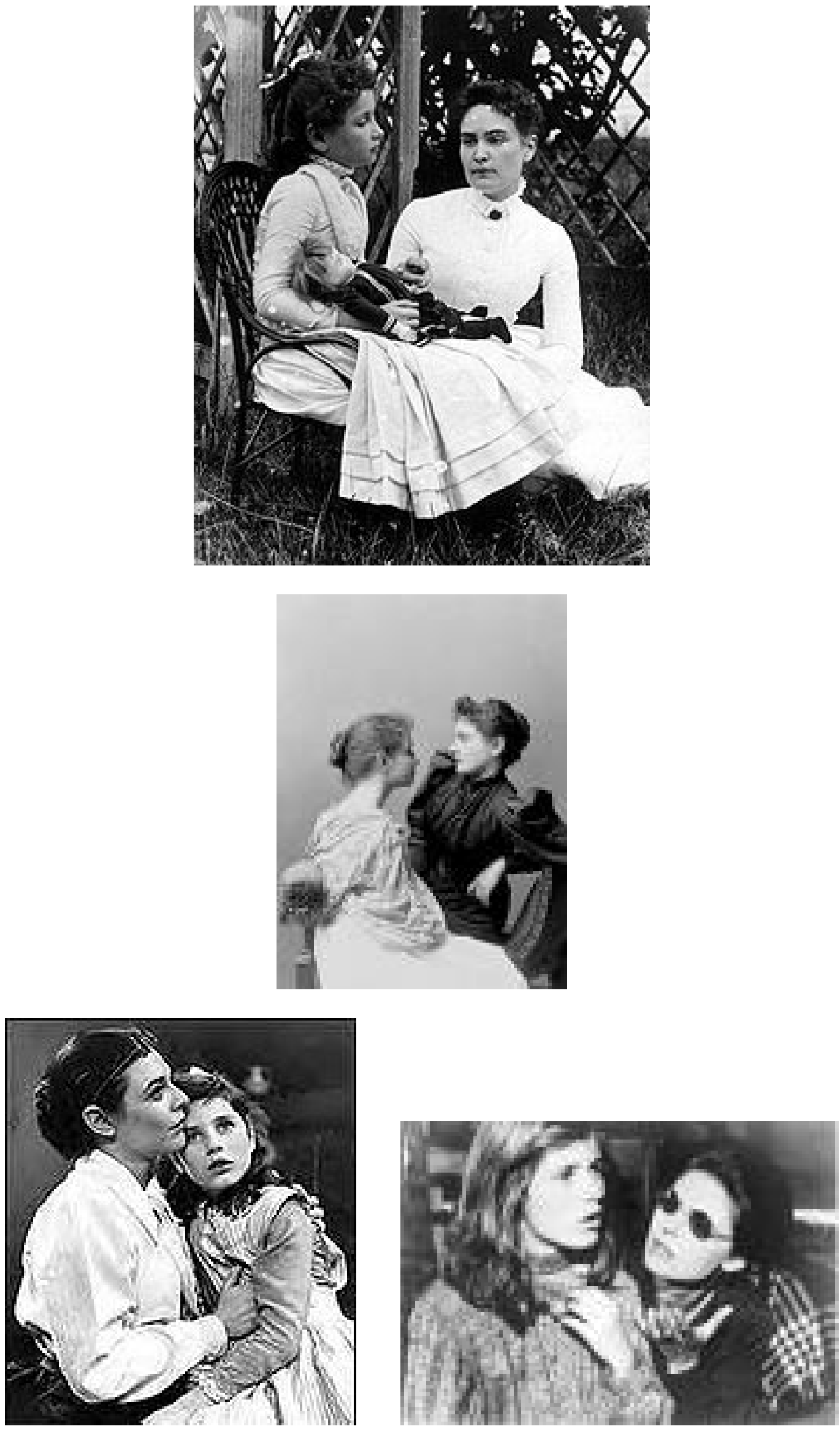

Anne Banckoft e Patty Duke no filme “The Miracle worker”, 1936. 

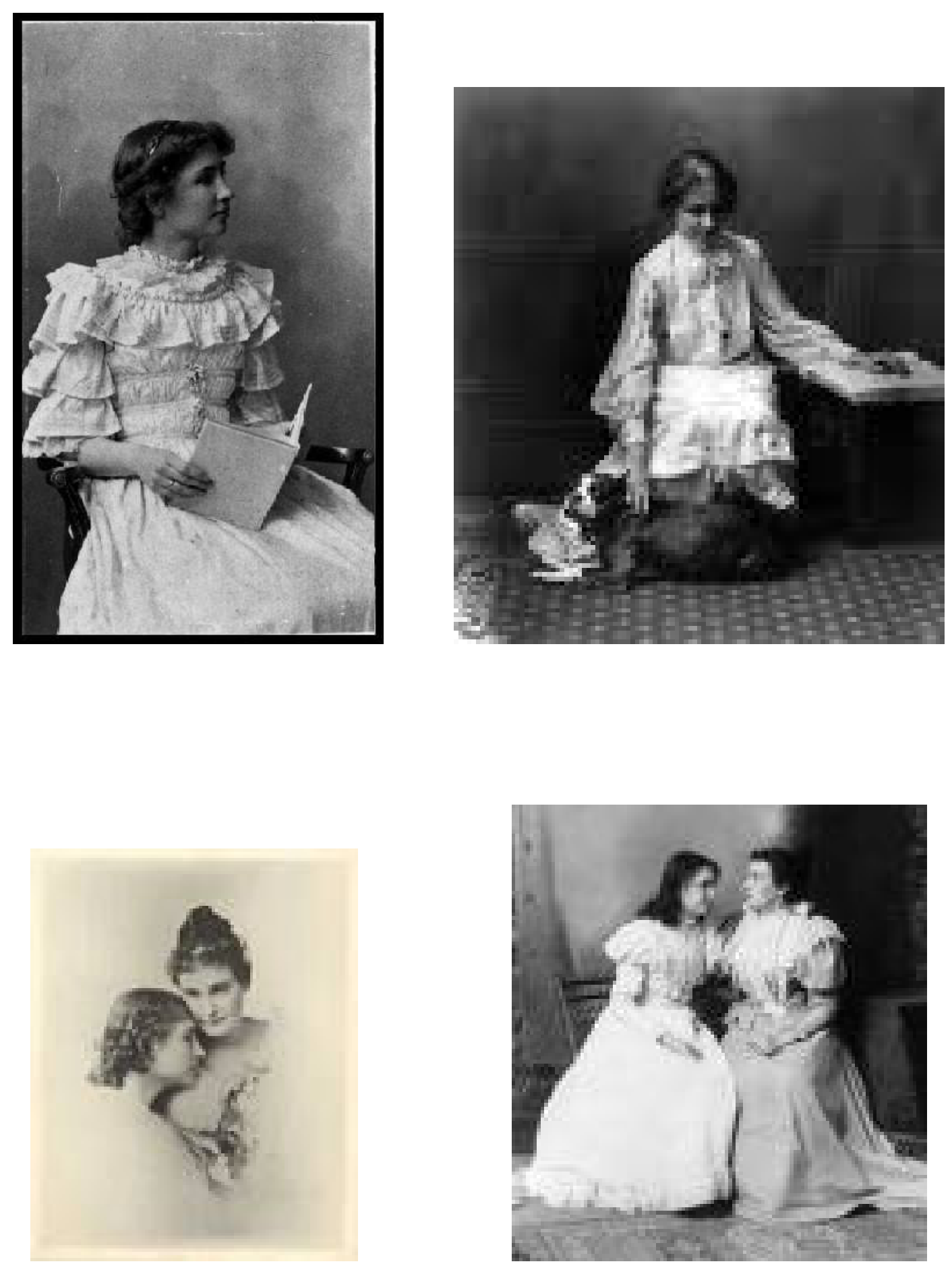

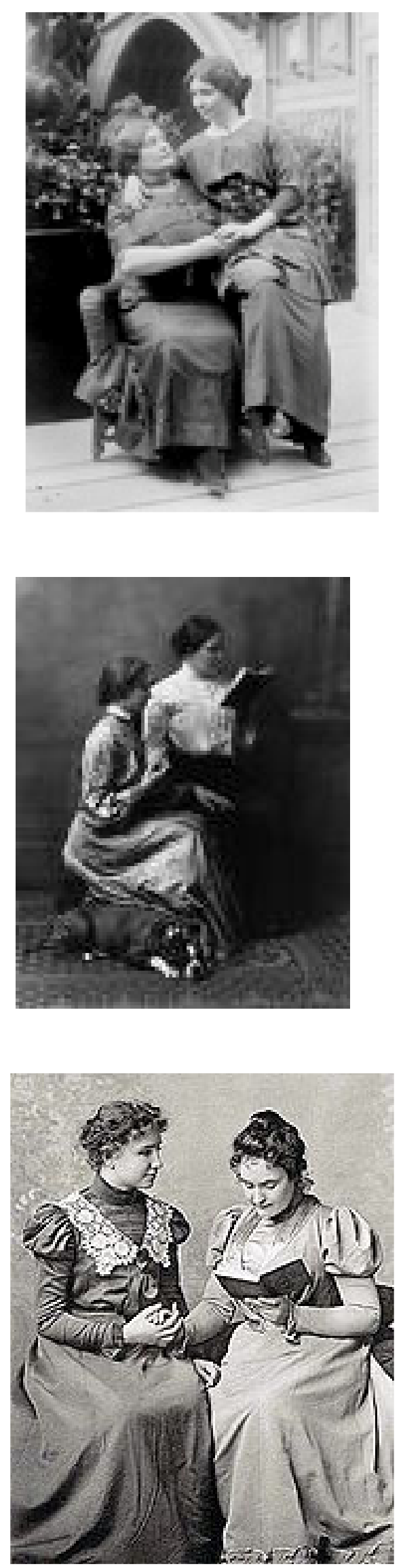


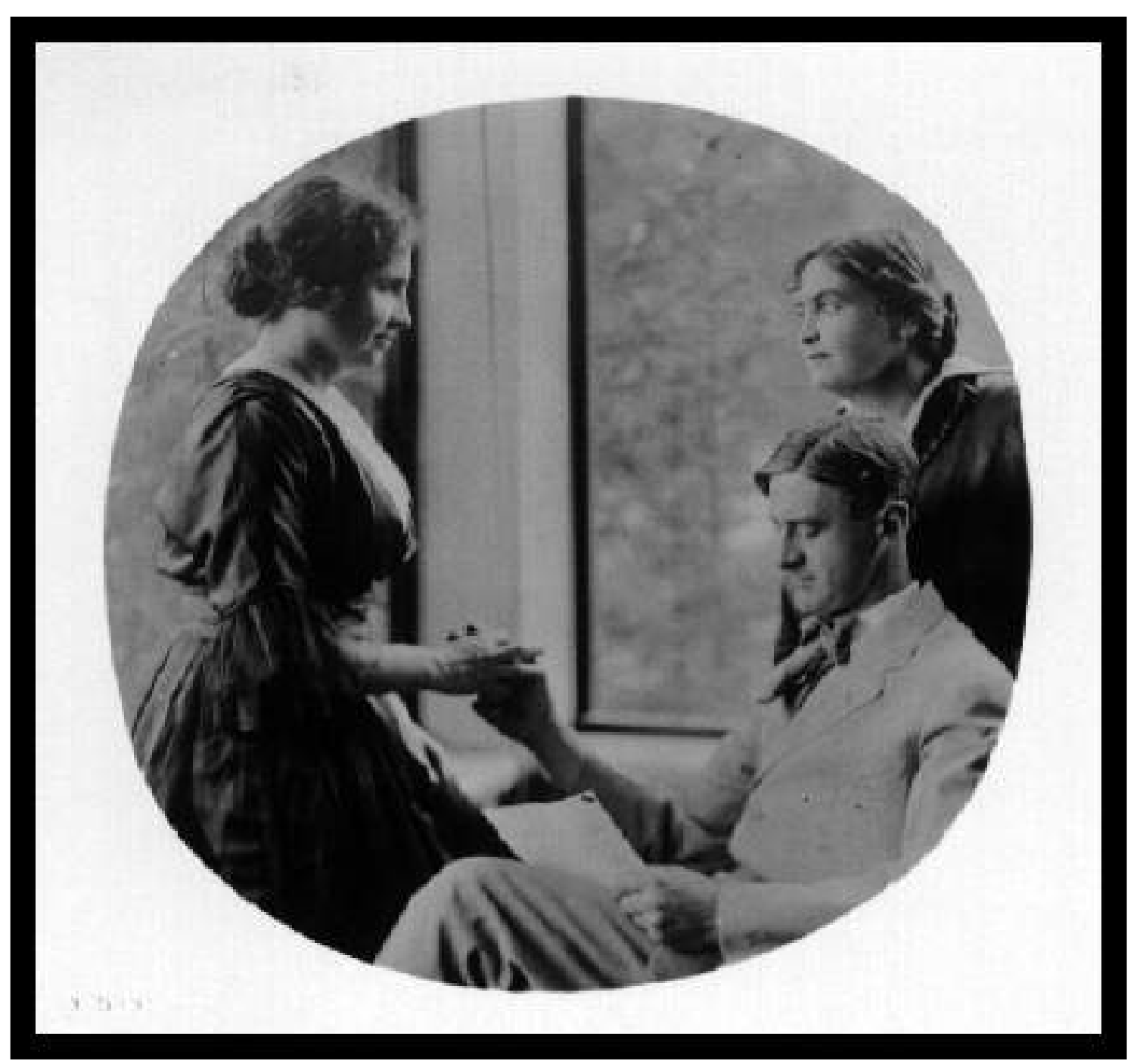

Helen Keller, Anne Sullivan e John Macy

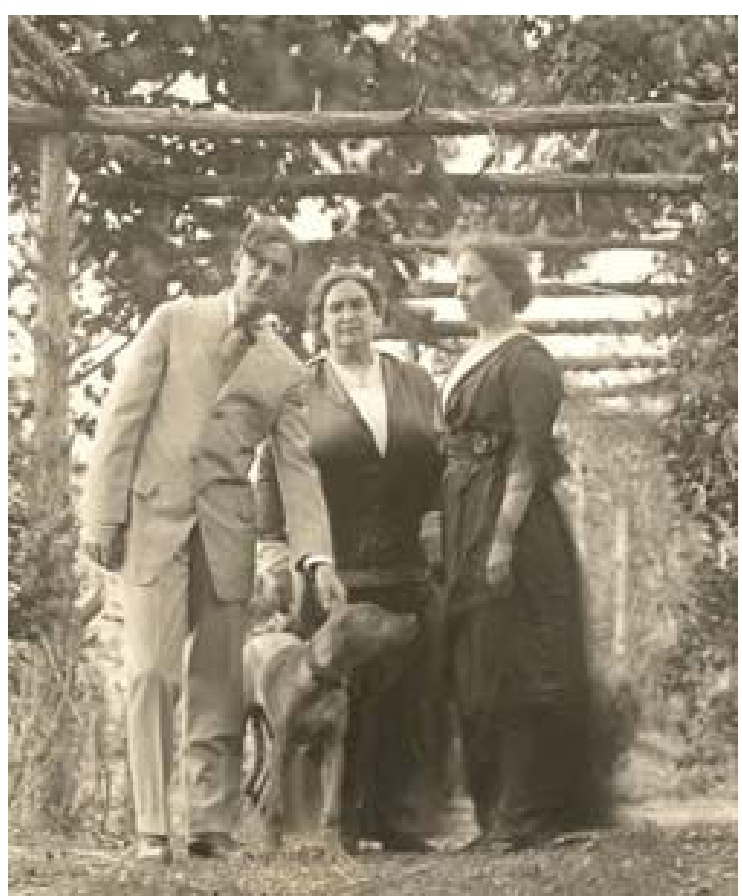



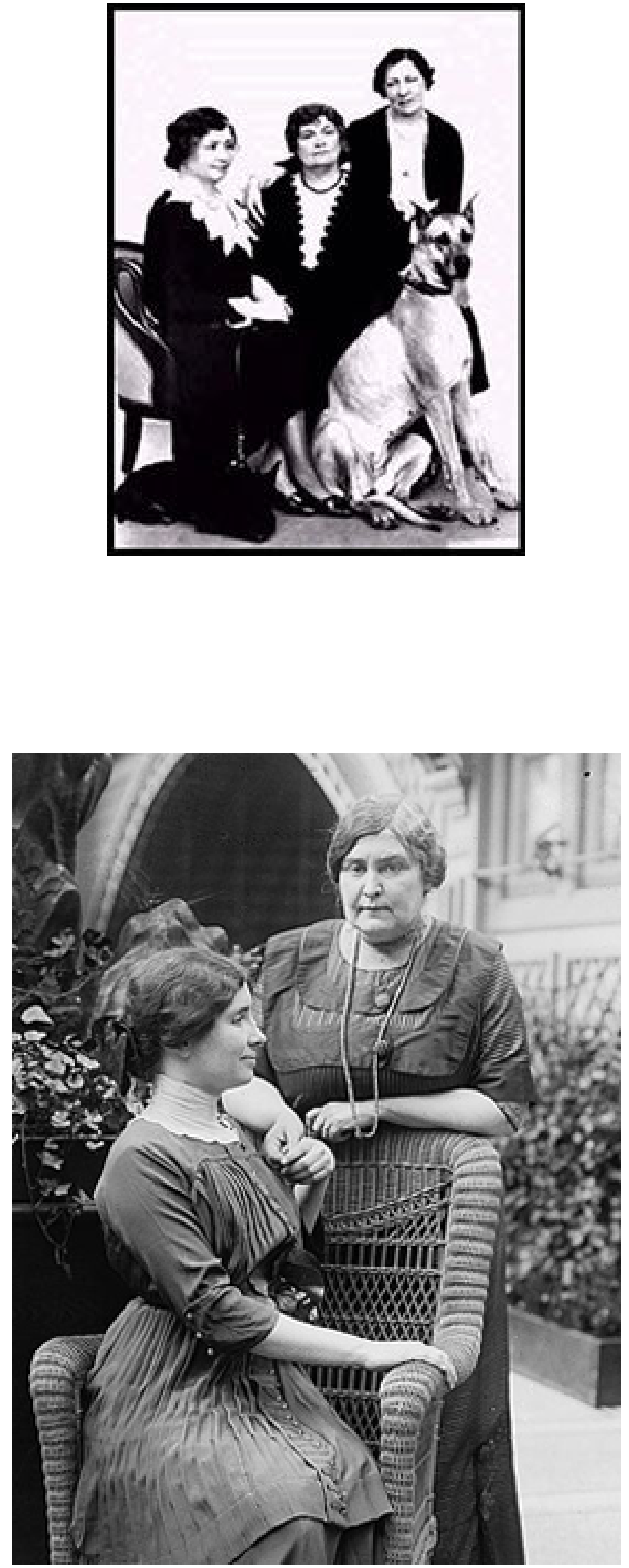

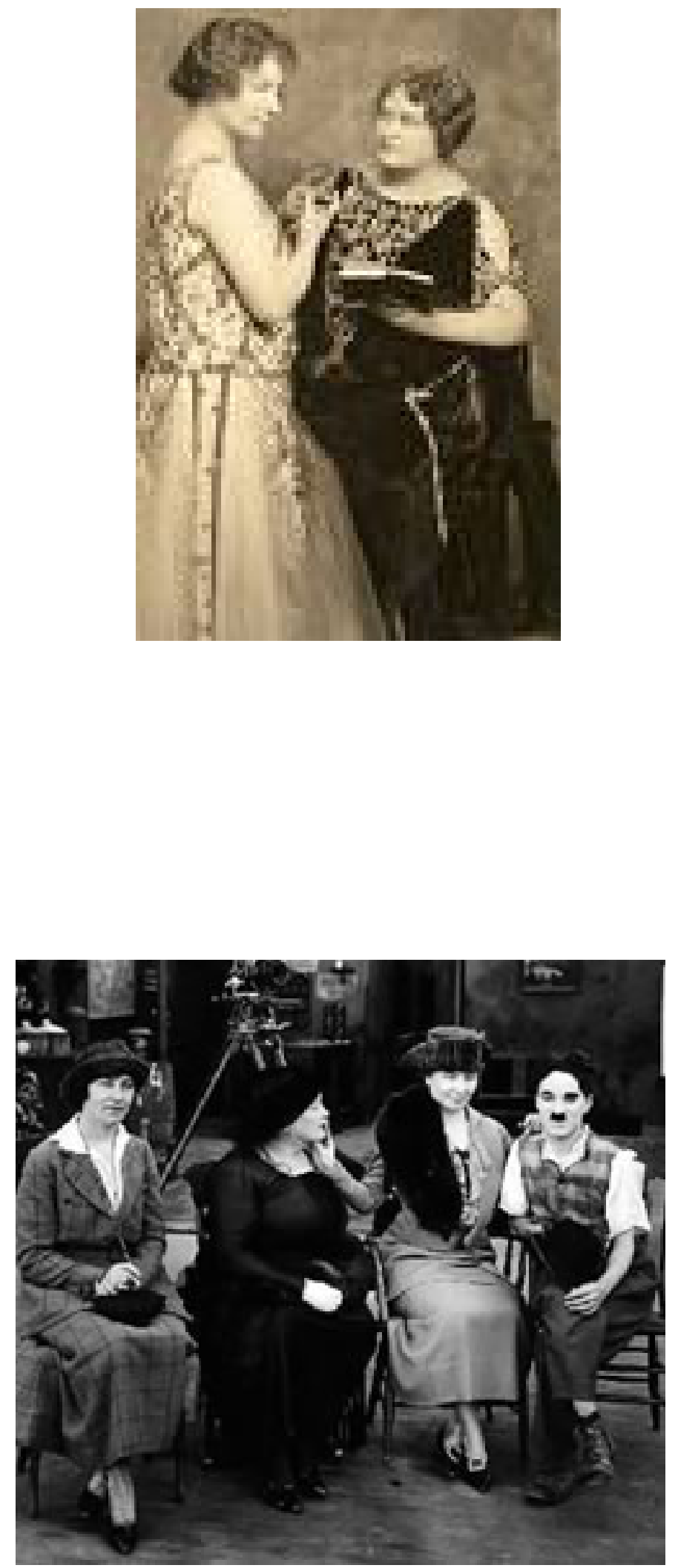

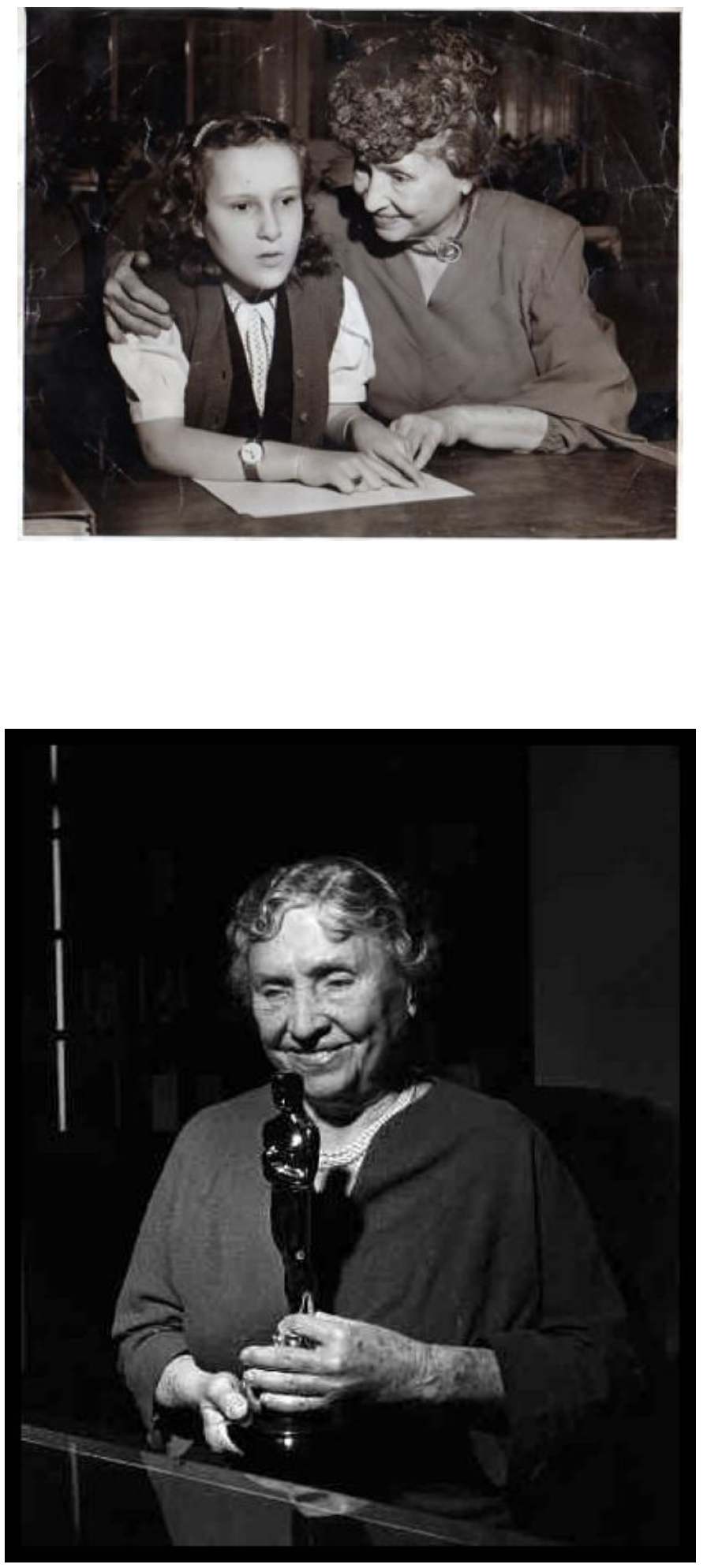


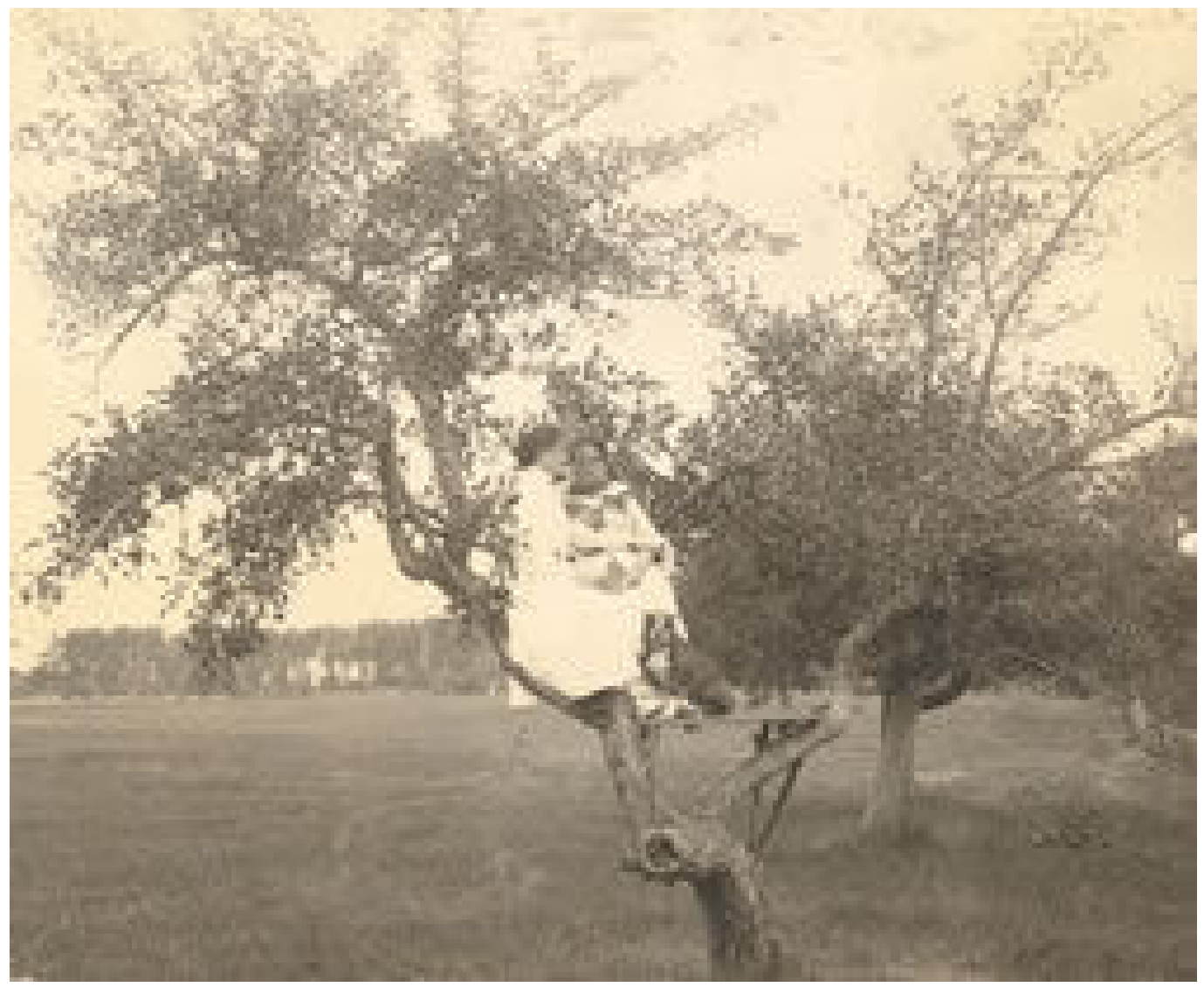




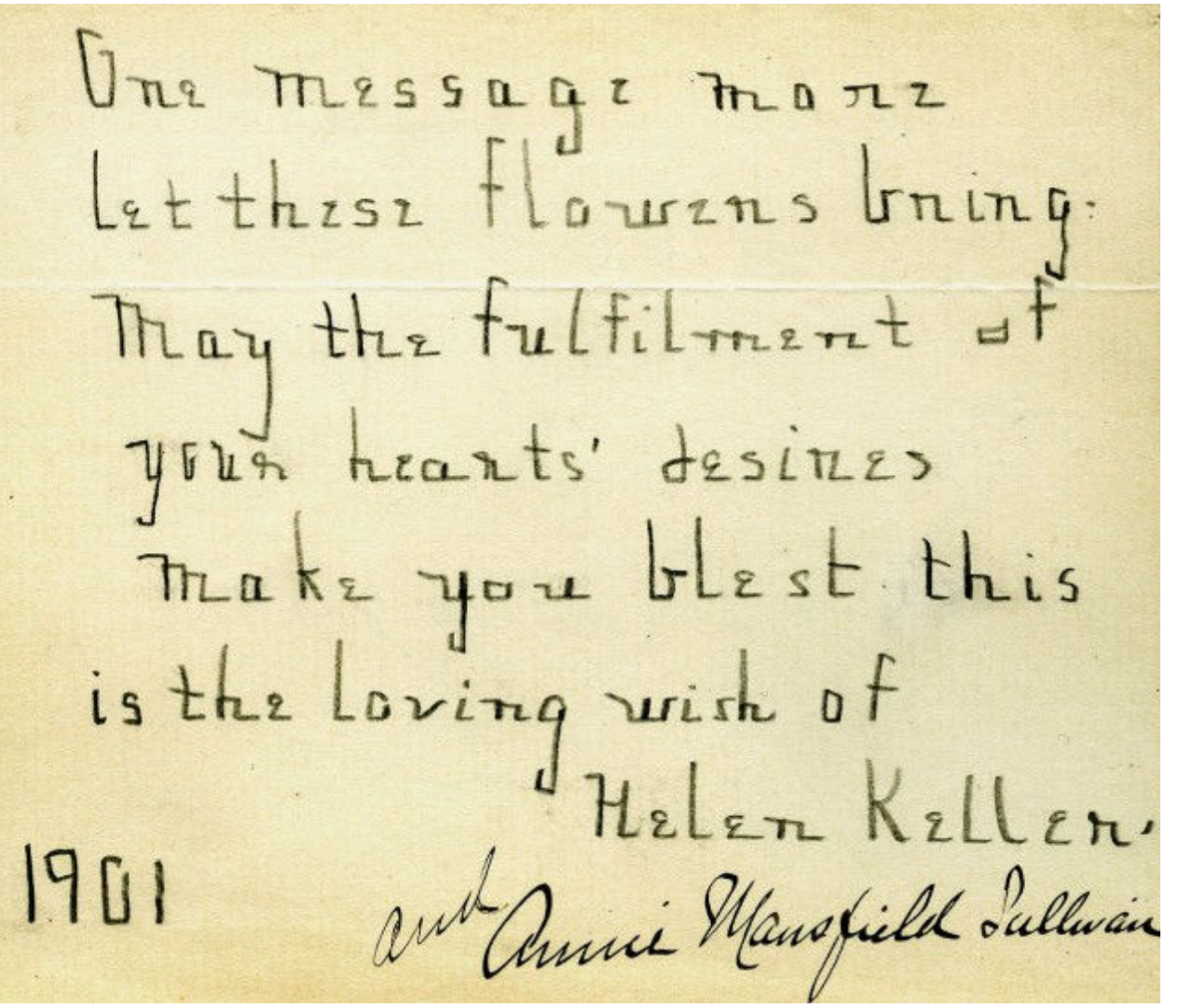


ANEXO D - Sylvia Bataille
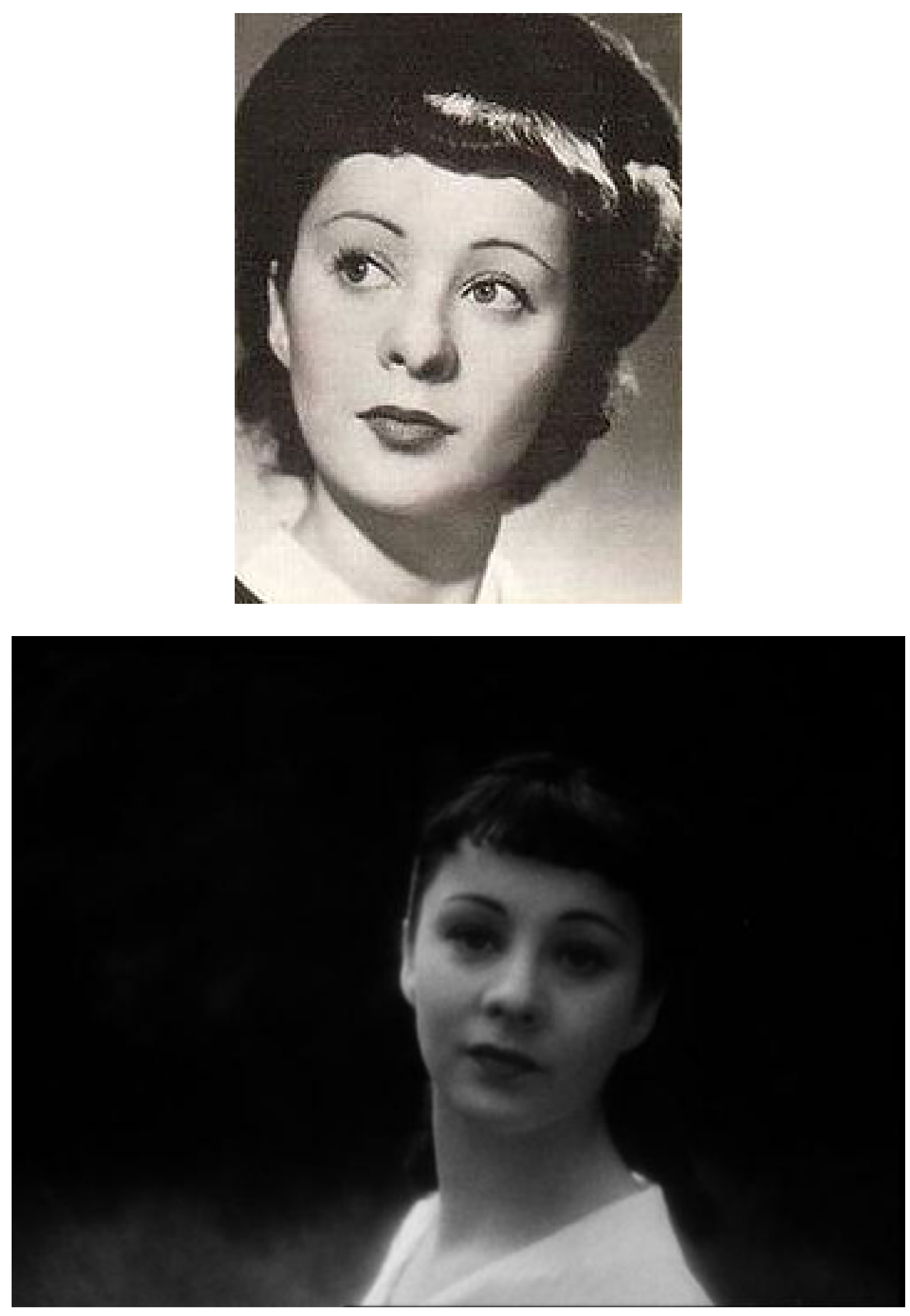

Em Une Partie de campagne, filme de Jean Renoir - 1936 
ANEXO E - Pintura, em madeira, de André Masson

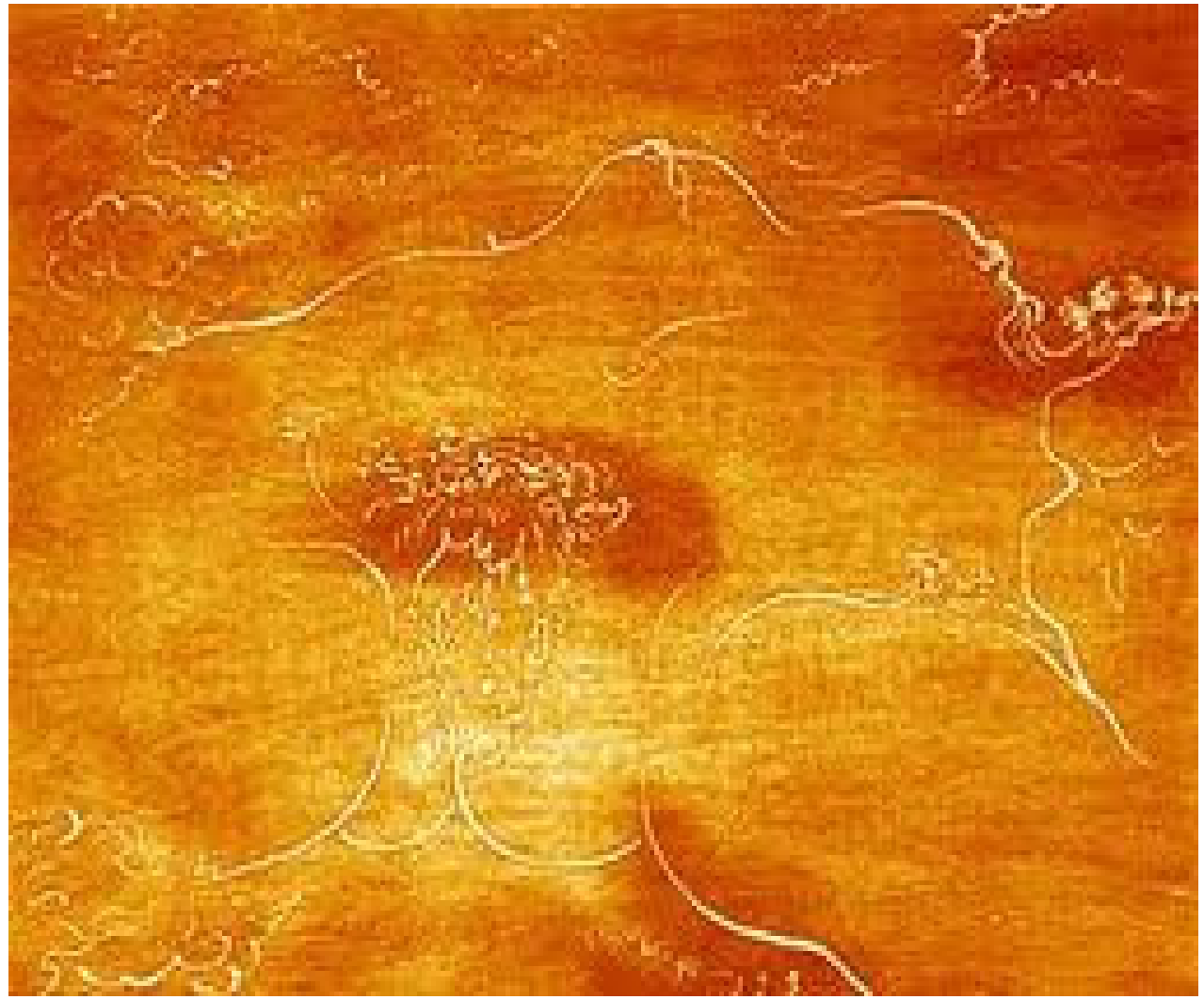


ANEXO F - A origem do mundo, óleo sobre tela, de Gustave Courbet

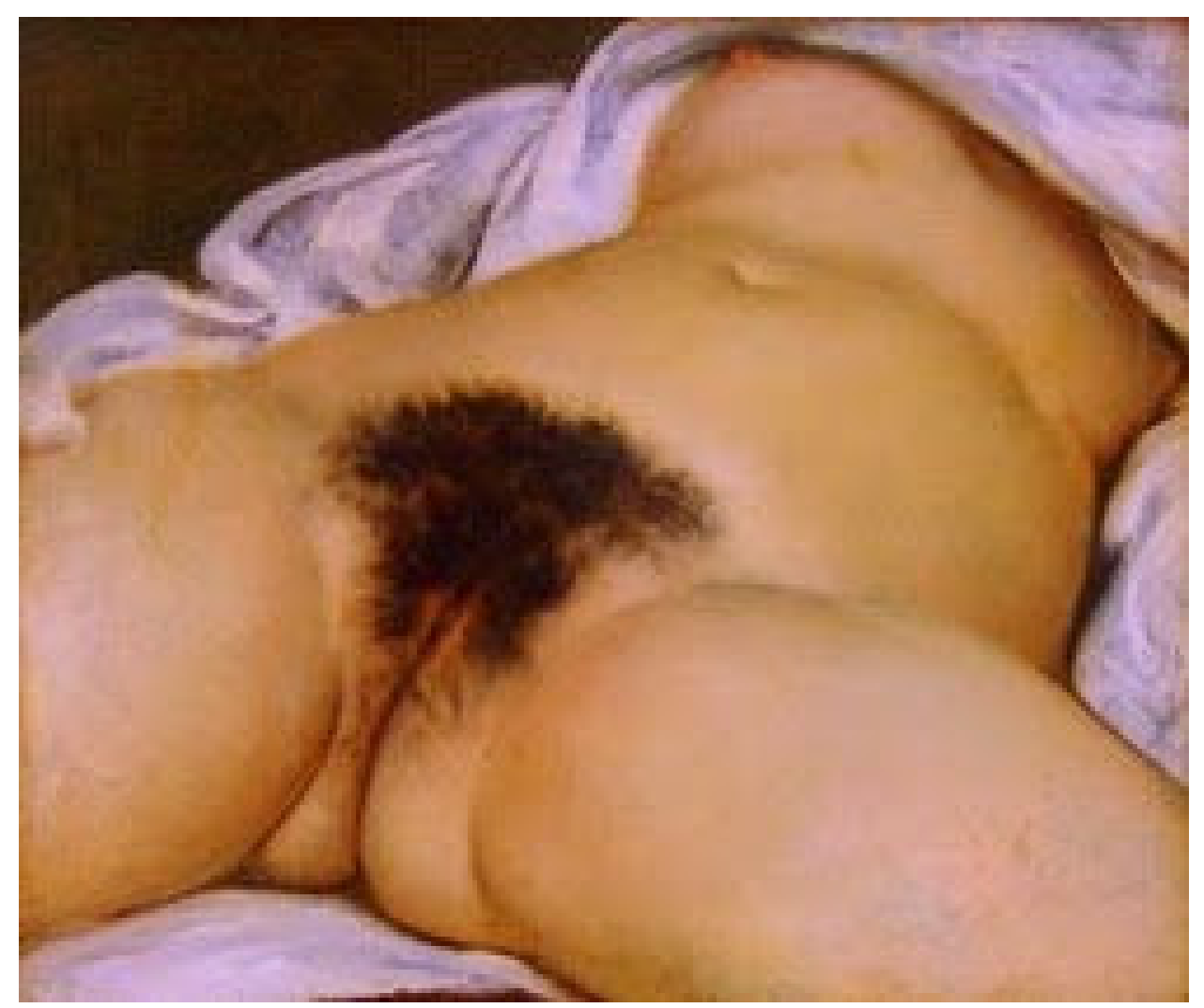


Evoé! 